UNIVERSIDADE DE SÃO PAULO

FACULDADE DE FILOSOFIA, LETRAS E CIÊNCIAS HUMANAS DEPARTAMENTO DE LETRAS CLÁSSICAS E VERNÁCULAS

PROGRAMA DE PÓS-GRADUAÇÃO EM FILOLOGIA E LÍNGUA PORTUGUESA

\title{
GÊNEROS DO DISCURSO, CIÊNCIA E JORNALISMO: O TEMA DA SAÚDE EM REPORTAGENS DE CAPA DA SUPERINTERESSANTE
}

Ariadne Mattos olímpio

São Paulo

2006 
UNIVERSIDADE DE SÃO PAULO

FACULDADE DE FILOSOFIA, LETRAS E CIÊNCIAS HUMANAS

DEPARTAMENTO DE LETRAS CLÁSSICAS E VERNÁCULAS

PROGRAMA DE PÓS-GRADUAÇÃO EM FILOLOGIA E LÍNGUA PORTUGUESA

\title{
GÊNEROS DO DISCURSO, CIÊNCIA E JORNALISMO: O TEMA DA SAÚDE EM REPORTAGENS DE CAPA DA SUPERINTERESSANTE
}

\author{
Ariadne Mattos olímpio
}

\begin{abstract}
Dissertação de mestrado apresentada ao Programa de Pós-Graduação em Filologia e Língua Portuguesa, do Departamento de Letras Clássicas e Vernáculas da Faculdade de Filosofia, Letras e Ciências Humanas da Universidade de São Paulo, para obtenção do título de Mestra em Letras.
\end{abstract}

Orientadora: Prof ${ }^{a}$ Dr $^{a}$ Sheila Vieira de Camargo Grillo

São Paulo

2006 



\section{AGRADECIMENTOS}

Em primeiro lugar, agradeço à professora Sheila Vieira de Camargo Grillo pela acolhida na orientação, pela confiança no meu trabalho, pela doçura e, ao mesmo tempo, firmeza com que conduziu nossos encontros e por ter feito eu me encantar ainda mais pela linguagem. Agradeço também à minha “avó intelectual” Beth Brait, pela atenção dedicada e dicas oferecidas ao meu relatório de qualificação. À Helena Brandão, professora de graduação, pós-graduação, com quem tive meu primeiro e apaixonante contato com a Análise do Discurso. Ao pessoal do grupo "Seminários de Pesquisa": Flávia Ferraz, Simone Veloso, Solange Santos, Alberto Ribeiro e Rosangela Prietro, companheiros com quem a troca de idéias foi fundamental para a realização deste trabalho. Um agradecimento especial aos meus queridos amigos André Xavier, Cristiane Silva, Flávia Ferraz, Renata Moreira e Aleta Esposito, sem os quais a minha vida nesta faculdade não teria tido a menor graça. Ao Rafael Brandão, meu cientista maior, pelo apoio, carinho e amor de tanto tempo. Ao meu pai José, que foi e sempre será o meu melhor professor de português e o grande culpado pela minha escolha por Letras, a ele agradeço todo o seu entusiasmo com os passos que dou nesta carreira. À minha mãe Sandra, por ter me envolvido, desde eu menina, ao mundo da literatura, pelas infinitas conversas e pelas nossas eternas (assim espero) “farrinhas”. À minha irmã, Lígia, que consegue despertar em meu coração um amor sem limites. Agradeço aos meus pais e à minha irmã por acreditarem em mim, por acompanharem a minha vida de maneira sempre tão vibrante e por serem quem são. 
Para os meus pais, Sandra e José e para minha irmã, Lígia. 


\section{Resumo}

Esta dissertação pretende mostrar como o tema da saúde é produzido no gênero reportagem de capa de uma revista impressa de reportagens de Jornalismo Científico, a Superinteressante. O corpus é formado por reportagens de capa de 17 edições da revista, distribuídas diacronicamente em 3 períodos: $1^{\circ}$ ) 1988/1989; $2^{\circ}$ ) 1995/1997; $3^{\circ}$ ) 2002/2003. Busca-se analisar como o gênero reportagem de capa é constituído na articulação entre aspectos verbais e não-verbais; como se dá, nesse gênero, o encontro de dois campos de atividade humana (o campo da ciência e o campo do jornalismo) e, finalmente, quais transformações históricas ocorreram não só nesse gênero como também no tratamento do tema da saúde. A fundamentação teórica está embasada nas noções de gênero do discurso, dialogismo e polifonia desenvolvidas pelo Círculo de Bakhtin e também nas análises de autores que se debruçaram sobre a questão da Divulgação Científica.

Palavras-chave: Língua Portuguesa, Gêneros de Discurso, Divulgação Científica, Mídia. 


\begin{abstract}
This thesis intends to show how the health theme is produced in the genre cover reportage of an impressed magazine of Scientific Journalism, Superinteressante. The corpus is formed by cover reportage of 17 editions of the magazine, distributed diachronically in three periods: $1^{\circ}$ ) 1988/1989; $2^{\circ}$ ) 1995/1997; $3^{\circ}$ ) 2002/2003. It also searches for analyzing how the genre cover reportage is built in the articulation of verbal and non verbal aspects; how, in this genre, two fields of the human activity encounter (the scientific and the journalism field) and, finally, which historical changes occurred not only in this genre but also in the treatment of the health theme. The theoretical is based on the genres of the discourse notions, dialogism and polyphony developed by the Bakhtin Circle and also on the authors who have been studying about the Scientific Divulgation.
\end{abstract}

Key words: Portuguese Language, Genres of the Discourse, Scientific Divulgation, Media. 


\section{Sumário}

Introdução

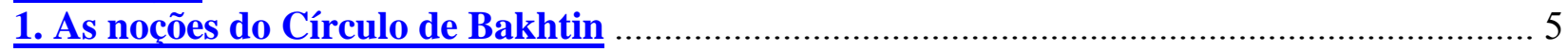

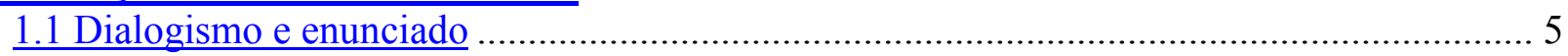

1.2 Palavra e signo ideológico .......................................................................................... 8

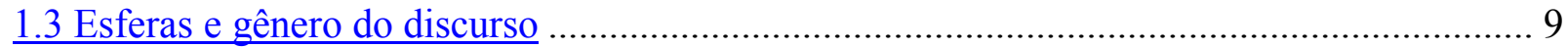

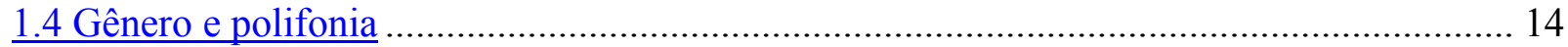

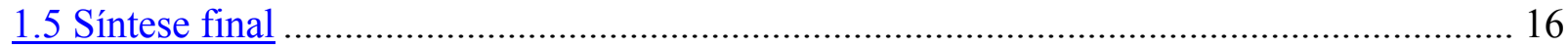

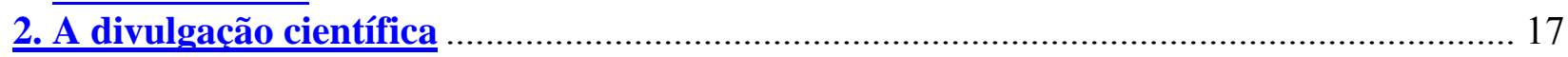

$2.1 \mathrm{O}$ papel social da divulgação científica .......................................................................... 17

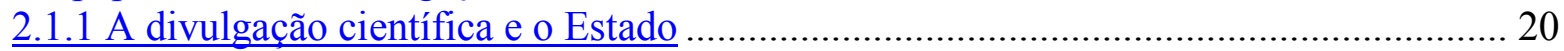

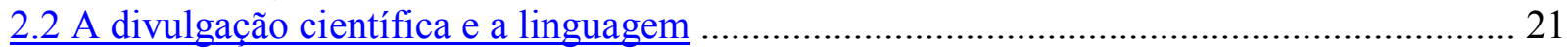

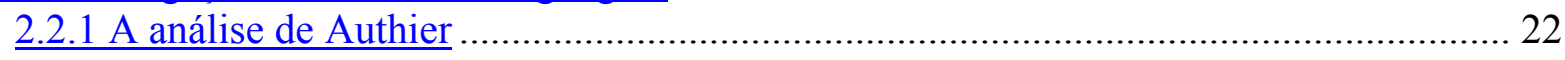

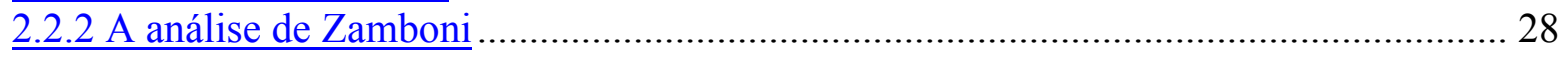

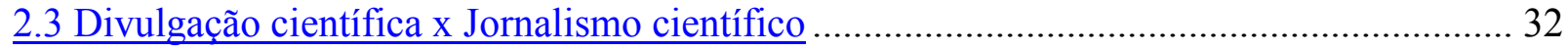

3. Metodologia

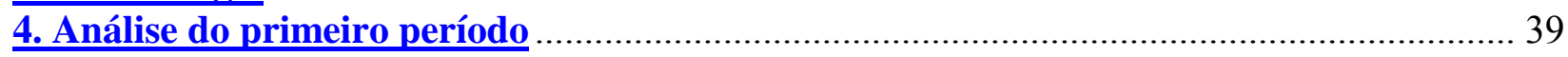

4.1 Os elementos do peritexto

4.2 A noção de discurso citado para o Círculo de Bakhtin.......................................................... 40

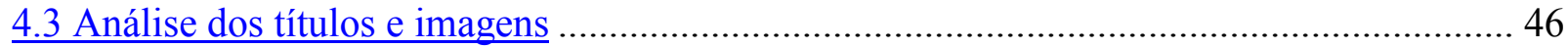

4.3.1 Superinteressante - março de 1988 ............................................................................ 46

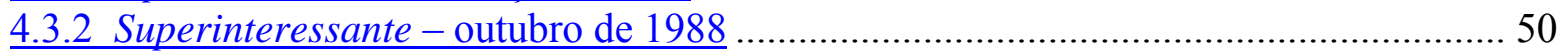

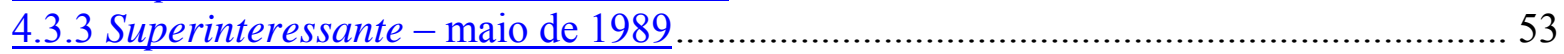

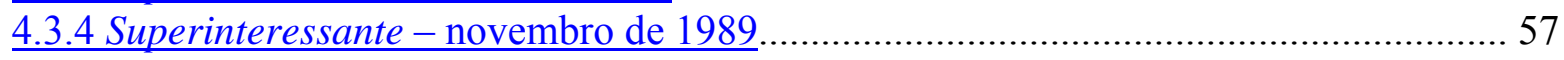

4.3.5 Síntese dos títulos e imagens do primeiro período:........................................................ 59

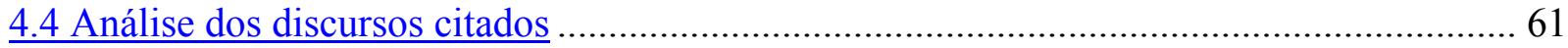

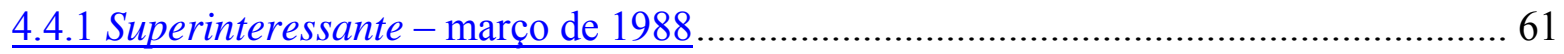

4.4.2 Superinteressante - outubro de 1988 ………........................................................ 66

4.4.3 Superinteressante - maio de 1989 …………........................................................ 70

4.4.4 Superinteressante - novembro de 1989....................................................................... 73

4.4.5 Síntese do discurso citado no primeiro período................................................................ 76

5. Análise do segundo período

5.1 Análise dos títulos e imagens ....................................................................................... 78

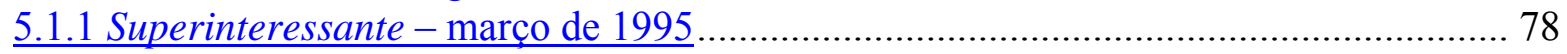

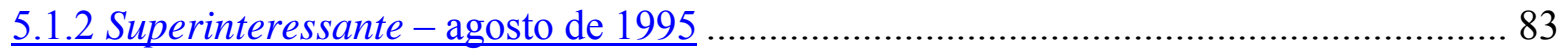

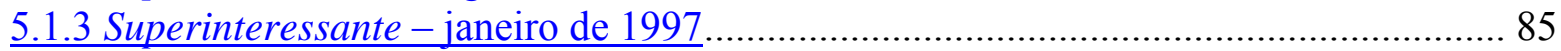

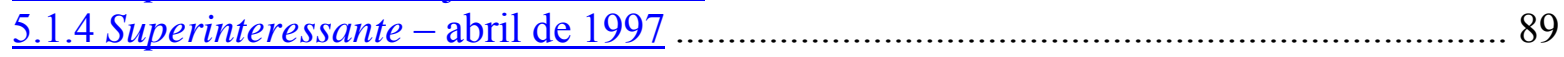

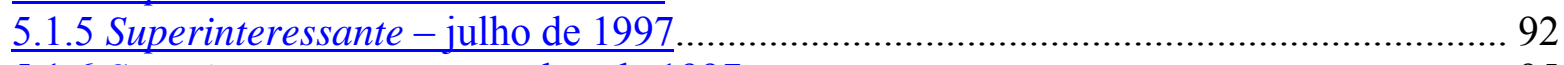

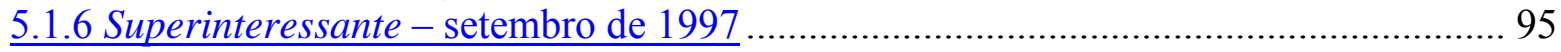

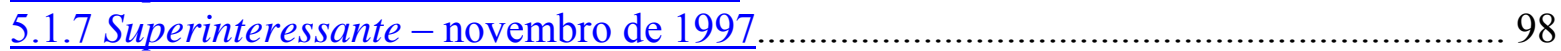

5.1.8 Síntese dos títulos e imagens do segundo período .................................................... 100

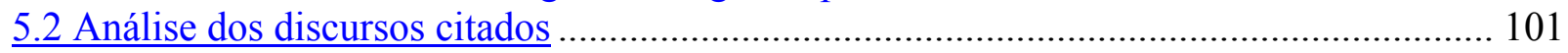

5.2.1 Superinteressante - março de 1995 ............................................................................. 101 
5.2.2 Superinteressante - agosto de 1995 ..................................................................... 105

5.2.3 Superinteressante - janeiro de 1997...................................................................... 108

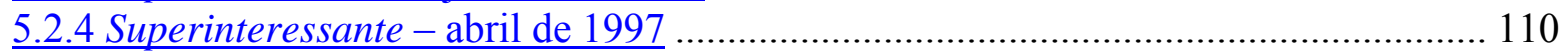

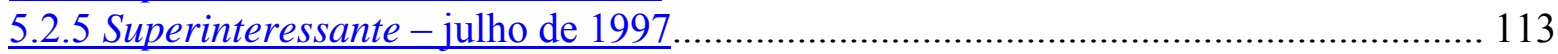

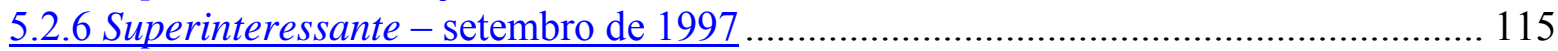

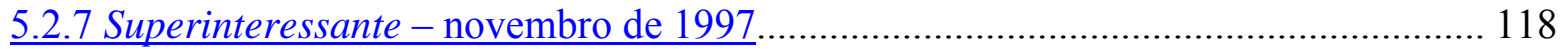

5.2.8 Síntese do discurso citado no segundo período ....................................................... 120

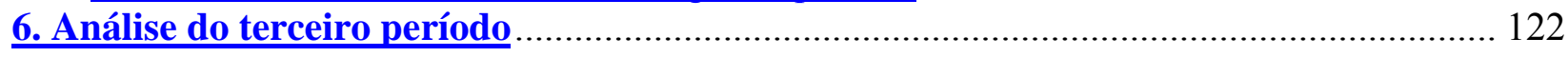

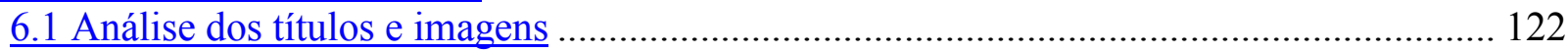

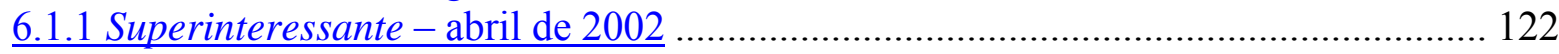

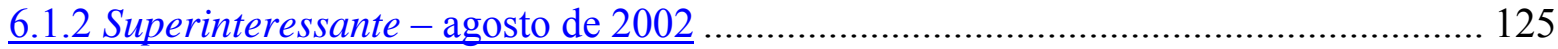

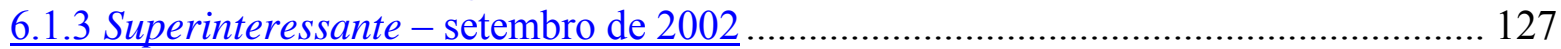

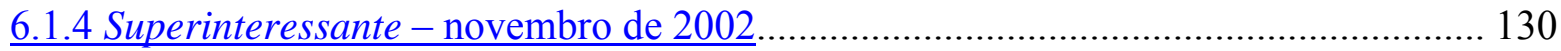

6.1.5 Superinteressante - fevereiro de 2003 .................................................................. 134

6.1.6 Superinteressante - outubro de 2003 .................................................................. 137

6.1.7 Síntese dos títulos e imagens do terceiro período......................................................... 139

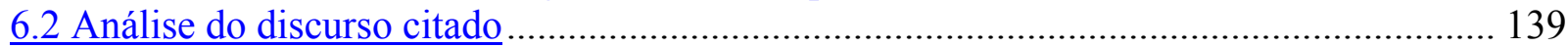

6.2.1 Superinteressante - abril de 2002 ........................................................................ 139

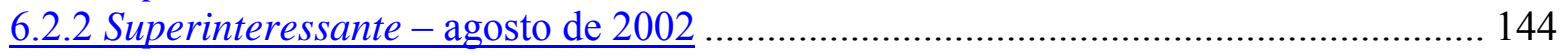

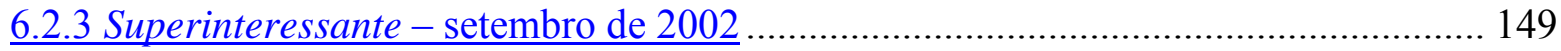

6.2.4 Superinteressante - novembro de 2002 ………................................................ 153

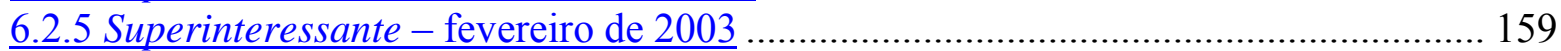

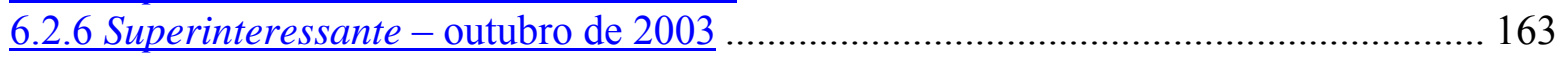

6.2.7 Síntese do discurso citado no terceiro período ........................................................... 166

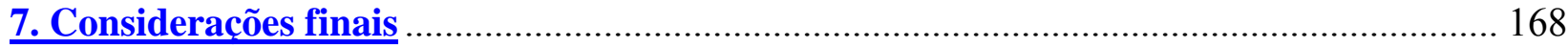

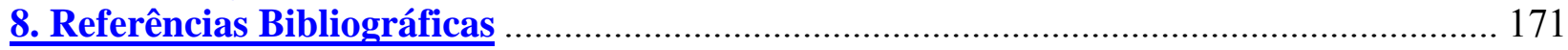




\section{Introdução}

A divulgação científica é uma prática discursiva que visa a aumentar o estado de conhecimento de um leitor ou de um ouvinte que não domina o discurso pertencente à esfera da ciência. A linguagem tem, nesta atividade, papel crucial, uma vez que ela é um dos fatores de êxito da divulgação científica. O exame das formas da língua nesta prática destaca-se como objeto de estudo na medida em que envolve fenômenos não só de ordem lingüística (discurso citado, reformulação etc) como também de ordem social (contribuição para a imagem da ciência como detentora do saber, importância dos cientistas para a sociedade etc).

O tema da saúde é hoje um dos maiores focos da divulgação científica já que o público parece querer ler o modo como a ciência pode ajudar a curar doenças e a prevenir a saúde. Não se trata de uma divulgação que pretende apenas satisfazer curiosidades, como seria o caso de saber se existe vida fora do nosso planeta, mas de "usar" a ciência no dia-a-dia, por meio de dicas e conselhos, já que ela tem legitimidade para oferecê-los.

A fim de analisar como esse tema é divulgado, embaso-me em alguns conceitos desenvolvidos pelo Círculo de Bakhtin como dialogismo, gêneros do discurso, discurso citado e polifonia que me ajudam a compreender a prática discursiva da divulgação científica. As idéias discutidas no Círculo permitem que se analisem, por exemplo, diferentes gêneros do discurso, sob a perspectiva de encará-los como enunciados relativamente estáveis do ponto de vista do tema, do estilo e da construção composicional. Valendo-me desta abordagem, procuro mostrar nesta dissertação como um gênero específico da esfera do jornalismo comercial, a saber, o gênero reportagem de capa de divulgação científica, é constituído na articulação entre aspectos verbais e não-verbais, como se dá, nesse gênero, o encontro de diferentes esferas da atividade humana (a esfera da ciência e a esfera do jornalismo) e, também, o encontro destas com a ideologia do cotidiano.

Esta dissertação está dividida em seis capítulos. No capítulo um, reúno alguns dos principais conceitos desenvolvidos pelo Círculo de Bakhtin que sinalizam para a compreensão não só da prática discursiva da divulgação científica, mas, num sentido mais amplo, para o entendimento da língua como um fenômeno social cuja essência é a interação verbal.

O capítulo dois traz a visão de jornalistas e lingüistas que se debruçaram sobre a atividade da divulgação científica. Exponho principalmente as posições de Authier-Revuz e Zamboni que divergem em relação a essa prática. Enquanto para Authier a divulgação científica é uma 
atividade de reformulação de um discurso-fonte em um discurso-segundo, para Zamboni trata-se não de reformulação, mas de formulação de um novo discurso. Esta autora compreende a divulgação científica como um gênero de discurso. Levando em consideração as noções de gêneros do discurso e esferas, desenvolvidas pelo Círculo, posiciono-me, neste capítulo, sobre a definição do lugar da divulgação científica. Considero-a não como um gênero do discurso, mas como uma atividade discursiva que se manifesta em diferentes gêneros pertencentes a diferentes esferas. Penso também que tanto a formulação quanto a reformulação estão integradas a essa prática discursiva.

No capítulo três, apresento a metodologia utilizada no trabalho, justificando a escolha do corpus que é formado por dezessete edições de uma revista impressa de divulgação científica pertencente à esfera do jornalismo comercial, a saber, a Superinteressante. A opção dessa revista se deve ao fato de ela ser, dentre as revistas de divulgação científica, a que possui a maior tiragem, além de ser a mais antiga produzida por uma editora comercial. O gênero escolhido foi a reportagem de capa já que é o que possui o maior destaque e atenção por parte dos produtores e dos leitores. O tema analisado, como já apontado anteriormente, é a saúde que pode influenciar diretamente o dia-a-dia das pessoas.

As edições analisadas pertencem a diferentes períodos da Superinteressante. O primeiro período, composto de quatro edições, compreende os anos iniciais da revista, 1988 e 1989. O segundo, com sete edições, refere-se aos anos de 1995 e 1997. Finalmente, o terceiro período, correspondendo aos anos de 2002 e 2003, possui seis edições. Essa seleção justifica mais um de meus objetivos nesta dissertação que é verificar quais transformações históricas ocorreram no gênero reportagem de capa e no tratamento dado ao tema da saúde.

Deste modo, os capítulos quatro, cinco e seis tratam, cada um, dos diferentes períodos analisados. Antes de analisar os períodos, exponho, no início do capítulo quatro, considerações teóricas a respeito das duas categorias analisadas nas reportagens, a saber, o discurso citado e elementos do plano peritextual (os títulos e as imagens) que, a princípio, podem apontar para o diálogo existente entre as diferentes esferas que compõem a atividade da divulgação científica.

Por fim, nas considerações finais, avalio em que medida a teoria utilizada na dissertação dá conta da análise do gênero reportagem de capa de divulgação científica. 


\section{As noções do Círculo de Bakhtin}

Bakhtin, grande pensador russo do século $\mathrm{XX}$, juntamente com outros pensadores que compunham o seu círculo tais como Voloshinov e Medvedev, discorreu sobre vários temas e conceitos que abarcam não só a área da Lingüística como também outras áreas ${ }^{1}$. Entretanto, para os propósitos deste trabalho, pretendo destacar apenas alguns conceitos ligados à área dos estudos da linguagem, a saber, dialogismo, enunciado, palavra e signo ideológico, gêneros do discurso e polifonia.

\subsection{Dialogismo e enunciado}

Segundo Bakhtin/Voloshinov, em Marxismo e Filosofia da Linguagem (1929/2004), o dialogismo é uma propriedade intrínseca do enunciado. Por dialogismo entende-se não só a comunicação em voz alta com pessoas colocadas face a face ${ }^{2}$, mas também o vínculo que existe entre os enunciados de dada esfera da atividade humana e também entre os enunciados de um determinado gênero do discurso. Isto quer dizer que um enunciado é sempre uma resposta, ou seja, uma réplica a enunciados anteriores. Além disso, deve ter também uma disposição para que outros tenham uma ativa compreensão responsiva em relação a ele. Bakhtin/Voloshinov exemplificam esse diálogo no sentido mais amplo com um livro:

O livro, isto é, o ato de fala impresso, constitui igualmente um elemento da comunicação verbal. Ele é objeto de discussões ativas sob a forma de diálogo e, além disso, é feito para ser apreendido de maneira ativa, para ser estudado a fundo, comentado e criticado no quadro do discurso interior, sem contar as reações impressas, institucionalizadas, que se encontram nas diferentes esferas da comunicação verbal (críticas, resenhas, que exercem influência sobre os trabalhos posteriores, etc.). Além disso, o ato de fala sob a forma de livro é sempre orientado em função das intervenções na mesma esfera. (2004, p.123).

Como se vê, um livro também é um enunciado que está em diálogo com outros enunciados do mesmo campo. Mas o que o círculo entende por enunciado?

\footnotetext{
${ }^{1}$ Clarck \& Holquist (1998) afirmam que Bakhtin é um dos principais pensadores do século XX e que "seus escritos abarcam, ao lado da lingüística, da psicanálise, da tecnologia e da teoria social, a poética histórica, a axiologia e a filosofia da pessoa" (p.21).
} 
Enunciado deve ser entendido como algo realizado, aquilo que foi efetivamente dito por alguém e se tornou disponível para a resposta do outro. Enunciado, portanto, é diferente de oração como bem explica Bakhtin no famoso texto Os gêneros do discurso, presente em Estética da criação verbal (1979/2003), obra que se compõe de uma coletânea de textos seus escritos em épocas diferentes. O limite de um enunciado é definido pela alternância dos sujeitos do discurso, como podemos notar nesta passagem do texto

Os limites da cada enunciado concreto como unidade da comunicação discursiva são definidos pela alternância dos sujeitos do discurso, ou seja, pela alternância dos falantes. Todo enunciado - da réplica sucinta (monovocal) do diálogo cotidiano ao grande romance ou tratado científico - tem, por assim dizer, um princípio absoluto e um fim absoluto: antes do seu início, os enunciados de outros; depois do seu término, os enunciados responsivos de outros (ou ao menos uma compreensão ativamente responsiva silenciosa do outro ou, por último, uma ação responsiva baseada nessa compreensão). (1979/2003, p.275).

Já a oração, por sua vez, não apresenta esta característica; ela tem "natureza gramatical, fronteiras gramaticais, lei gramatical e unidade" (1979/2003, p.278) e, além disso, ela é "desprovida da capacidade de determinar imediata e ativamente a posição responsiva do falante" (1979/2003, p.287).

Há, ainda, um outro aspecto do enunciado que o difere da oração. Para o Círculo, todo enunciado possui um tema. E o que vem a ser tema?

Em Marxismo, há um capítulo intitulado Tema e Significação em que Bakhtin/Voloshinov fazem uma distinção entre aquilo que não pode ser repetido (tema) e aquilo que pode (significação). O tema é o sentido do enunciado e, como este, é sempre individual e nãoreiterável. Assim, um enunciado como 'Que horas são?'3 terá um sentido diferente a cada vez que for utilizado, já que o enunciado depende, pela definição dos autores, de uma situação histórica concreta "em que é pronunciada e da qual constitui na verdade um elemento" (1929/2004, p.128). Para eles, o tema de um enunciado "é determinado não só pelas formas lingüísticas que entram na composição (as palavras, as formas morfológicas ou sintáticas, os sons, as entoações), mas igualmente pelos elementos não verbais da situação" (1929/2004, p.128). Já a significação é o aspecto do enunciado que pode ser repetido uma vez que ela é um aparato técnico para a

\footnotetext{
${ }^{2}$ Essas duas pessoas não correspondem àquela dicotomia saussureana falante $\mathrm{x}$ ouvinte. Para Bakhtin/Voloshinov, essas duas pessoas são igualmente produtoras do discurso, da interação verbal.

${ }^{3}$ O exemplo é dos autores (1929/2004, p.128).
} 
realização do tema. A significação contém elementos da enunciação que são reiteráveis e idênticos cada vez que são repetidos. Entretanto, o Círculo ressalta que esses elementos reiteráveis que formam a significação são abstratos uma vez que, fundados sobre uma convenção, não têm existência concreta independente. Em um dicionário, por exemplo, há a significação de uma palavra, isto é, os significados que elas podem vir a ter e os significados que ela, historicamente, já possuiu ${ }^{4}$. A partir do momento em que usamos aquela palavra, ela se atualiza em um enunciado e, conseqüentemente, passa a ter um sentido, um tema que, inclusive, pode ser diferente daquelas acepções presentes no dicionário. Isso porque a palavra foi usada num contexto sócio-histórico determinado e, como se sabe, esses aspectos extraverbais são de crucial importância na teoria bakhtiniana.

Com a noção de enunciado em mente, podemos agora voltar a Marxismo, mais precisamente no capítulo intitulado A interação verbal quando Bakhtin/Voloshinov insistem no caráter dialógico da linguagem e afirmam mais uma vez que este enunciado deve estar em interação:

A verdadeira substância da língua não é constituída por um sistema abstrato de formas lingüísticas nem pela enunciação monológica isolada, nem pelo ato psicofisiológico de sua produção, mas pelo fenômeno da interacão verbal, realizada através da enunciação ou das enunciações. A interação verbal constitui assim a realidade fundamental da língua (1929/2004, p.123).

Essa interação verbal não é, como já se disse, um diálogo entre duas pessoas ${ }^{5}$, mas manifesta-se em todos os gêneros do discurso em que sempre estamos respondendo a algo que já foi dito e, além disso, esperamos também, por parte do ouvinte/leitor, uma resposta. Entretanto, a marca do outro em nosso enunciado não aparece somente em suas "molduras", isto é, o que veio antes e o que virá depois, mas também dentro do próprio enunciado.

Assim, os autores dedicam a terceira parte de Marxismo e filosofia da linguagem para demonstrar a voz do outro em um enunciado. Daí a importância que eles conferem ao estudo da sintaxe, uma vez que, dentre todos os níveis de análise, é justamente esse o nível que mais se aproxima dos atos de fala. Trata-se não de uma sintaxe abstrata, mas de uma voltada para a comunicação verbal. Os autores elegem, dentro da sintaxe, o fenômeno do discurso citado já que

\footnotetext{
${ }^{4}$ Cereja (2005), apoiado na teoria bakhtiniana, analisa a significação e o tema da palavra companheiro quando das eleições para a presidência da república em 2002.
} 
este vai apresentar esquemas em que se transmitem enunciações do outro na enunciação do eu e que, portanto, estão orientados sociologicamente. Isto quer dizer que as formas de se transmitir as falas de alguém estão correlacionadas a certos contextos sociais de produção e de recepção de tais falas.

São três capítulos em que os autores procuram tipologizar as formas de discurso citado exemplificando, mais uma vez, o caráter dialógico da linguagem:

o discurso citado é visto pelo falante como a enunciação de uma outra pessoa, completamente independente na origem, dotada de uma construção completa, e situada fora do contexto narrativo. É a partir dessa existência autônoma que o discurso de outrem passa para o contexto narrativo, conservando o seu conteúdo e ao menos rudimentos da sua integridade lingüística e da sua autonomia estrutural primitivas (1929/2004, p.144).

O discurso do outro pode passar sintaticamente para o discurso narrativo através de três esquemas: o discurso direto e suas variantes, o discurso indireto e suas variantes e o discurso indireto livre. Essas três maneiras de transmitir o discurso alheio serão mais bem exploradas em outro capítulo deste trabalho. Por ora, basta saber que o nosso enunciado, além de ser um elo na cadeia da comunicação verbal humana com aqueles limites de que trata Bakhtin, carrega consigo marcas do enunciado do outro, o que visivelmente depreendemos através desses esquemas de marcação do discurso citado.

\subsection{Palavra e signo ideológico}

Antes de discorrer sobre a noção de gêneros do discurso, é necessário expor o que Bakhtin/Voloshinov falam sobre o signo. Para os autores, signo é tudo aquilo que possui um valor ideológico: "ao lado dos fenômenos naturais, do material tecnológico e dos artigos de consumo, existe um universo particular, o universo dos signos" (1929/2004, p.32). Esse universo não apenas reflete a realidade como também a refrata: "ele pode distorcer essa realidade, ser-lhe fiel, ou apreendê-la de um ponto de vista específico, etc. Todo signo está sujeito aos critérios de avaliação ideológica (isto é: se é verdadeiro, falso, correto, justificado, bom, etc.)” (1929/2004, p.32).

\footnotetext{
${ }^{5}$ Quando pensamos em interação verbal, o gênero do diálogo oral entre duas pessoas é aquele que imediatamente nos vem à mente. Bakhtin (1979/2003) nos diz que é neste gênero que observamos com maior clareza e precisão a alternância dos sujeitos no discurso além de ele ser a forma clássica de comunicação discursiva.
} 
A palavra, por ser o signo mais neutro, acaba preenchendo qualquer espécie de função ideológica, tais como a estética, a científica, a moral, a religiosa. Além disso, a palavra é o material privilegiado da comunicação da vida cotidiana que, por sua vez, não está vinculada a nenhuma esfera ideológica particular. Além desses usos, ela é, ainda, utilizável como signo interior, isto é, como parte de nossa consciência sem que precise ser externalizada. Segundo Bakhtin/Voloshinov, "é devido a esse papel excepcional de instrumento da consciência que $a$ palavra funciona como elemento que acompanha toda criação ideológica, seja ela qual for. A palavra acompanha e comenta todo ato ideológico" (1929/2004, p.37).

Deste modo, como a palavra pode ser utilizada por todas as esferas ideológicas bem como pela ideologia cotidiana, ela acaba carregando valores contraditórios: "as palavras são tecidas a partir de uma multidão de fios ideológicos e servem de trama a todas as relações sociais em todos os domínios" (1929/2004, p.41). Ela possui uma "ubiqüidade social” já que perpassa todos essas esferas. Esferas diferentes e classes sociais diferentes utilizam-se das mesmas palavras. Daí a famosa afirmação de Bakhtin/Voloshinov que diz "o signo se torna a arena onde se desenvolve a luta de classes" (1929/2004, p.46).

\subsection{Esferas e gênero do discurso}

Certas considerações a respeito dos gêneros do discurso ${ }^{6}$ aparecem em Marxismo $e$ filosofia da linguagem, através dessas considerações sobre a palavra como um signo neutro perpassando todos os campos da atividade de comunicação.

Para Bakhtin/Voloshinov, a ideologia do cotidiano, ou a psicologia do corpo social para usar o termo da teoria marxista, é o elo entre a superestrutura (as ideologias) e a infra-estrutura (a realidade, a estrutura sócio-política-econômica). Isso quer dizer que "os sistemas construídos da moral social, da ciência, da arte e da religião cristalizam-se a partir da ideologia do cotidiano, exercem por sua vez sobre esta, em retorno, uma forte influência e dão assim normalmente o tom a essa ideologia" (1929/2004, p.119). Esses 'sistemas', portanto, não refletem a realidade, mas sim a refratam uma vez que essa 'cristalização' se dá, como vimos, sob a forma da interação

\footnotetext{
${ }^{6}$ Souza (2003), no artigo Gêneros discursivos e Marxismo e filosofia da linguagem, procura mostrar que a noção de gênero não fica muito clara na edição brasileira de 1979, traduzida a partir da francesa (1977). Entretanto, tanto a edição espanhola (1992) quanto a francesa e a americana (1973), todas traduzidas diretamente do russo, conseguem dar a devida importância à questão dos gêneros, mostrando sua visível presença em Marxismo.
} 
verbal que, por sua vez, manifesta-se na forma de diferentes esferas da atividade humana. Assim, um mesmo dado da realidade pode ser apreendido de diferentes maneiras pelas diferentes esferas. Daí a idéia de refração da realidade: “cada campo de criatividade ideológica tem seu próprio modo de orientação para a realidade e refrata a realidade à sua própria maneira" (1929/2004, p.33). Assim, a esfera da atividade de comunicação é o primeiro nível em que um enunciado vai sofrer determinadas coerções, imprimindo-se nele as produções ideológicas próprias de cada esfera. Essa idéia é semelhante à do sociólogo Pierre Bourdieu (2003) que diz que entre a realidade e as produções culturais como, por exemplo, literatura e ciência (superestrutura para Bakhtin/Voloshinov), não há uma relação direta, erro que Bourdieu denomina de 'curto-circuito'. A ligação entre esses dois pólos se dá através de campos. Os campos ou microcosmos são espaços relativamente autônomos em relação ao macrocosmo (superestrutura) e possuem "os agentes e as instituições que produzem, reproduzem ou difundem a arte, a literatura ou a ciência" (2003, p.20), melhor dizendo: um campo tem mais ou menos capacidade de refratar as demandas externas. Como sociólogo, sua tarefa consiste em analisar o funcionamento dos campos e o grau de autonomia de que eles desfrutam. Deste modo, quanto mais autônomo o campo for, mais ele poderá refratar e retraduzir a realidade.

A aproximação de Bourdieu com o Círculo ainda se expressa na medida em que esses pensadores inseriram a questão do social, da história, do sujeito e da ideologia em suas teorias. Mais precisamente na obra do Círculo, a questão da interação verbal deve ser estudada levandose em consideração a noção de campo. Segundo Grillo (2005),

A interação se dá entre indivíduos organizados socialmente, o que coloca em jogo
condiçóes sócio-históricas de duas ordens. Primeira, a situação social mais imediata,
cujos componentes [...] são o horizonte social comum aos co-enunciadores (a unidade do
lugar visível), o conhecimento e a compreensão da situação, compartilhados pelos co-
enunciadores, e a avaliaçãa que eles fazem dessa situação. Segunda, o meio social mais
amplo, definido, por um lado, pelas especificidades de cada campo da produção
ideológica (ciência, literatura, jornalismo, religião etc), e, por outro, por um certo
"horizonte social" de temas recorrentes, em razão da onipresença social da linguagem
verbal e da relação que os campos ideológicos estabelecem com a ideologia do cotidiano
[...]. (2005, p.157).

Entretanto, os gêneros do discurso que se materializam nessa interação verbal não levam em conta somente as esferas em que são produzidos, mas também são condicionados pelo conteúdo temático, pelo estilo e pela forma composicional. Segundo Bakhtin, no texto Os gêneros do discurso,

todos esses três elementos - o conteúdo temático, o estilo, a construção composicional estão indissoluvelmente ligados no todo do enunciado e são igualmente determinados 
pela especificidade de um determinado campo da comunicação. Evidentemente, cada enunciado particular é individual, mas cada campo de utilização da língua elabora seus tipos relativamente estáveis de enunciado, os quais denominamos gêneros do discurso. $(1979 / 2003$, p.261).

Também neste texto, portanto, percebemos que gênero do discurso é a soma de aspectos verbais e extraverbais. Analisarei agora os três elementos que compõem o gênero: estilo, forma composicional (ou construção composicional) e tema.

O estilo (uma das noções mais complexas na obra de Bakhtin) seria não só a seleção dos recursos lexicais, fraseológicos e gramaticais da língua feita pelo falante (“a própria escolha de uma determinada forma gramatical pelo falante é um ato estilístico”(1979/2003, p.269), como também o estilo próprio do gênero. Para Bakhtin, "o estilo integra a unidade de gênero do enunciado como seu elemento" (1979/2003, p. 266). Deste modo, dificulta-se a compreensão do estilo individual, entendido há tempos como algo particular do autor. Bakhtin diz, entretanto, que o estudo do estilo individual é possível desde que se analise como esse estilo individual aponta para o estilo genérico, já que dentro do gênero há coerções lingüísticas, enunciativas e discursivas. Entretanto, há alguns gêneros que não deixam transparecer o estilo individual. Tratase daqueles que requerem uma forma padronizada. Segundo Bakhtin,

todo enunciado [...] é individual e por isso pode refletir a individualidade do falante (ou de quem escreve), isto é, pode ter estilo individual. Entretanto, nem todos os gêneros são igualmente propícios a tal reflexo da individualidade do falante na linguagem do enunciado, ou seja, ao estilo individual. Os gêneros mais favoráveis da literatura de ficção: aqui o estilo individual integra diretamente o próprio edifício do enunciado, é um de seus objetivos principais [...]. (1979/2003, p.265).

Brait (2005), no artigo Estilo, em que trata de analisar este elemento na obra de Bakhtin, busca compreender o estilo sob um ângulo dialógico, uma vez que dialogismo é a reflexão central da obra do círculo. Percorrendo os vários textos em que o círculo discorre sobre o estilo, a autora vai mostrando que esse elemento depende do "tipo de relação existente entre o locutor e os outros parceiros da comunicação verbal, ou seja, o ouvinte, o leitor, o interlocutor próximo e o imaginado (o real e o presumido), o discurso do outro etc" (2005, p.89). Afinal, como prega o dialogismo bakhtiniano, todo enunciado é dirigido a alguém. Resta saber o grau de relação existente entre locutor e interlocutor em determinado enunciado. Assim, por exemplo, quando Bakhtin estuda a obra de Dostoievski, ele nos diz que o estilo desse autor não pode basear-se somente na lingüística, mas deve levar em conta o campo em que se deu aquela comunicação já que a palavra sempre deve estar em interação. Deste modo, passa-se a um estudo de uma 
estilística individual para uma estilística discursiva. Brait também observa considerações sobre o estilo quando Bakhtin/Voloshinov discorrem sobre o fenômeno do discurso citado na terceira parte de Marxismo e filosofia da linguagem:

Como se pode observar nesse estudo, as formas possíveis do discurso citado, que têm historicidade e não permanecem idênticas ao longo do tempo e nas diferentes culturas, assumem também a condição de estilo, confirmando a idéia de que o estilo, longe de se esgotar na autenticidade de um indivíduo, inscreve-se na língua e nos seus usos historicamente situados. (2005, p.83)

O estilo, portanto, é formado pelo campo em que está inserido, pelas formas de citar o discurso de outrem, pela entonação avaliativa do autor/falante e também pelo papel que esse atribui ao leitor/ouvinte que, por sua vez, acaba contribuindo também para o estilo de determinado enunciado.

Quanto à forma composicional, pode-se dizer que ela é o "esqueleto", o tipo de estruturação que determinado enunciado tem. Trata-se aqui de aspectos de natureza formal/lingüística, das coerções estruturais dos gêneros. Quando Bakhtin afirma que um dos limites do enunciado é a compreensão responsiva do outro, imediatamente pensamos em como o outro é capaz de apreender o fim do enunciado para daí ter uma compreensão responsiva. A forma composicional é responsável, dentre outros fatores, por esse acabamento. Os outros dois fatores que se ligam intimamente à construção composicional são a exauribilidade do objeto e do sentido e o projeto de discurso ou vontade de discurso do falante. A exauribilidade do objeto e do sentido varia de acordo com a esfera e, embora haja esferas em que essa exauribilidade seja mais difícil de ser alcançada, como na esfera da ciência, um falante sempre tenta mostrar uma relativa conclusibilidade do sentido já que ele possui em projeto de discurso ou uma vontade discursiva que vai determinar o todo de seu enunciado. Entretanto, para que um falante tenha um projeto de discurso que terá um sentido mais ou menos concluído, ele deve, antes de tudo, escolher um gênero no qual concretizará seu discurso. Nas palavras de Bakhtin,

A intenção discursiva do falante, com toda a sua individualidade e subjetividade, é em seguida aplicada e adaptada ao gênero escolhido, constitui-se e desenvolve-se em uma determinada forma de gênero. [...] todos os nossos enunciados possuem formas relativamente estáveis e típicas de construção do todo. (1979/2003, p.282)

Bakhtin afirma ainda que aprendemos a falar nossa língua materna não pela sua composição vocabular ou pela sua estrutura gramatical, mas antes pelos gêneros do discurso com suas formas relativamente estáveis de construção:

Nós aprendemos a moldar o nosso discurso em formas de gênero e, quando ouvimos o discurso alheio, já adivinhamos o seu gênero pelas primeiras palavras, adivinhamos um 
determinado volume (isto é, uma extensão aproximada do conjunto do discurso), uma determinada construção composicional, prevemos o fim, isto é, desde o início temos a sensação do conjunto do discurso que em seguida apenas se diferencia no processo da fala $(1979 / 2003$, p.283).

Já o tema cria no texto de Estética um paradoxo: como o tema pode ser aquilo que não é repetido, como disse Bakhtin em Marxismo, se ele deve apresentar, ao mesmo tempo, aquilo que é estável no gênero?

Em The formal method in literary scholarship (1928/1991), podemos encontrar pistas que nos ajudem a resolver esse aparente paradoxo. Nessa obra, Bakhtin/Medvedev dialogam com os formalistas e falam sobre o tema. Para Bakhtin/Medvedev, as palavras e as sentenças com um significado em comum podem formar sentenças comuns, mas não um tema, já que este não é um elemento puramente lingüístico: o tema transcende a língua. Ele é o enunciado todo, em um ato sócio-histórico definido e, portanto, não pode ser separado da situação:

O tema sempre transcende a língua. Além disso, é o enunciado como um todo, como uma performance do discurso que é direcionado ao tema, não a separação em palavra, sentença ou período. É o enunciado todo e suas formas, que não podem ser reduzidos às formas lingüísticas, que controlam o tema. O tema de um trabalho é o tema de um enunciado considerado como um ato sócio-histórico definido. Conseqüentemente, o tema é inseparável da situação total do enunciado bem como de seus elementos lingüísticos. (1928/1991, p.132) .

Além disso, são os gêneros que podem determinar o tema e eles, como se viu, não se prestam a determinações sintáticas. Os autores exemplificam com o conto de fadas cujo tema não consiste de sentenças ou períodos, mas está inseparável das circunstâncias de lugar e de tempo bem como das coerções do gênero conto de fadas. Para eles, o gênero sempre nos orienta, através dos seus enunciados possíveis a "criar" um tema: "A fim de criar um romance, é necessário aprender a ver a vida nos termos de uma história novelística [fábula], é necessário ver as relações mais amplas e mais profundas da vida em uma medida maior"8 (1928/1991, p.134). Isto quer dizer que um mesmo fato histórico pode ser diferentemente abordado se produzido neste ou naquele gênero e, aqui, a noção de tema se aproxima daquela vista anteriormente em Marxismo, já que uma palavra vai se atualizar de diferentes maneiras (caráter não repetível do tema),

\footnotetext{
7 "Theme always transcends language. Furthermore, it is the whole utterance as speech performance that is directed at the theme, not the separate word, sentence, or period. It is the whole utterance and its forms, which cannot be reduced to any linguistic forms, which control the theme. The theme of the work is the theme of the whole utterance as a definite sociohistorical act. Consequently, it is inseparable from the total situation of the utterance to the same extent that it is inseparable from linguistics elements".

8 "In order to create a novel it is necessary to learn to see life in terms of the novelistic story [fabula], necessary to learn to see the wider and deeper relationships of life on a large scale"
} 
dependendo do gênero em que for pronunciada. A acentuação valorativa é a forma como um gênero expressa a realidade. A acentuação valorativa é um traço constitutivo de todo enunciado e só existe nele, não existe no sistema da língua: “[...] a emoção, o juízo de valor, a expressão são estranhos à palavra da língua e surgem unicamente no processo do seu emprego vivo em um enunciado concreto" (1979/2003, p.292). O tema, portanto, é a abordagem que um determinado gênero faz de um dado da realidade. Assim, é como se usássemos óculos com lentes diferentes para enxergar a realidade. Esses óculos diferentes são os diferentes gêneros que apreendem dados do real. O tema de um dado da realidade é diferente cada vez que um gênero diferente o aborda. E aqui o tema ganha o seu caráter "relativamente estável", que faz com que os falantes consigam identificar um gênero bem como a esfera a que esse gênero pertence.

Uma vez que gêneros do discurso estão ligados às inesgotáveis possibilidades da atividade humana, o estudo deste fenômeno parece se tornar um grande desafio. Bakhtin não minimiza "a extrema heterogeneidade dos gêneros discursivos e a dificuldade daí advinda de definir a natureza geral do enunciado" (1979/2003, p.263). Para resolver este problema, ele faz uma grande divisão, diferenciando os gêneros discursivos primários (comunicação discursiva imediata, cotidiana - os vários tipos de diálogo oral) e os gêneros discursivos secundários que incorporam e reelaboram diversos gêneros primários (o romance, o artigo científico, o anúncio publicitário, etc). Contudo, é importante ressaltar que nessa incorporação e nessa reelaboração, os gêneros primários são uma representação por parte dos gêneros secundários.

\subsection{Gênero e polifonia}

Bakhtin, para tentar dar conta do fenômeno da linguagem, amplia as suas fronteiras, não se limitando apenas ao sujeito ou ao sistema da língua, mas levando em consideração as relações sociais, a história e a ideologia que também devem aparecer quando se quiser analisar a linguagem, justamente porque esses elementos aparecem, através das marcas lingüísticas, no enunciado. A interação verbal, seja ela ocorrendo face a face, seja ela pressupondo um interlocutor, seja ela respondendo a um enunciado anterior, está explicitada no enunciado. Bakhtin estuda a presença dessas interferências em um enunciado, comprovando, através das marcas lingüísticas, o dialogismo natural de todo enunciado. 
Um dos fenômenos estudados por Bakhtin é o discurso citado. Tanto em Questões de estética e literatura (1988) como em Problemas da poética de Dostoievski (1963/2002), Bakhtin procura demonstrar os procedimentos de transmissão do discurso de outrem, bem como o papel do contexto narrativo nestas transmissões.

No caso de Problemas, Bakhtin trabalhou com um gênero literário novo, a saber, o gênero do romance polifônico. Partindo da análise das obras de Dostoiévski, Bakhtin formula a noção da polifonia por estas obras apresentarem uma multiplicidade de vozes e consciências independentes que representam pontos de vista diferentes. Para Bakhtin, há sempre um conflito, uma polêmica entre essas diferentes vozes. Dostoiévski, portanto, através de seu romance polifônico, que é constituído de um conflito de vozes, consegue fazer que suas personagens não sejam objeto da palavra do autor, mas sim veículo de suas próprias palavras, dotadas de valor e poder plenos. Em Problemas, Bakhtin afirma que, ao contrário do que acontecia no gênero romanesco até então, nos romances de Dostoiévski,

\begin{abstract}
não é a multiplicidade de caracteres e destinos que, em um mundo objetivo uno, à luz da consciência una do autor, se desenvolve nos seus romances; é precisamente a multiplicidade de consciências eqüipolentes e seus mundos que aqui se combinam numa unidade de acontecimento, mantendo a sua imiscibilidade. (1963/2002, p.4).
\end{abstract}

Contudo, da mesma maneira que um enunciado é sempre uma réplica a enunciados anteriores e torna-se também disponível para que outros tenham para com ele uma atitude responsiva, um gênero de uma dada esfera também o é. Isto quer dizer que o romance polifônico, apesar de novo, dialoga com os gêneros literários existentes até então. Segundo Bakhtin, encontramos traços de gêneros literários da Antigüidade nas obras de Dostoiévski, a saber, entre outros, a sátira menipéia que, dentre suas características estão o folclore carnavalesco e o elemento cômico. Encontrar vestígios da tradição em um novo é de fato um dos aspectos do gênero, na visão bakhtiniana:

Já sabemos, porém, que o começo, isto é, a archaica do gênero, conserva-se em forma renovada também nos estágios superiores de evolução do gênero. Além disso, quanto mais alto e complexo é o grau de evolução atingido pelo gênero, tanto melhor e mais plenamente ele revive o passado (1963/2002, p.121).

Uma outra característica do romance polifônico é a posição do autor em relação a seus personagens. Como já se disse, as palavras das personagens não são objeto da palavra do autor: "o herói tem competência ideológica e independência, é interpretado como autor de sua concepção filosófica própria e plena e não como objeto da visão artística final do autor" 
(1963/2002, p.3). Da mesma forma, não foi Dostoiévski quem, através do romance polifônico, conservou traços da sátira menipéia, mas foi o próprio gênero quem fez tal operação: "Em termos um tanto paradoxais, podemos dizer que quem conservou as particularidades da menipéia antiga não foi a memória subjetiva de Dostoiévski mas a memória objetiva do próprio gênero com o qual ele trabalhou" (1963/2002, p.121).

Assim, evita-se a confusão entre dois fenômenos diferentes que, por vezes, aparecem sob a mesma etiqueta. Enquanto dialogismo é característico de todo enunciado (que, necessariamente, contém marcas do discurso alheio), reserva-se o termo polifonia para falar de quando essas várias vozes presentes em um mesmo enunciado estão em conflito.

O dialogismo bakhtiniano tem seu conceito ampliado em Problemas da poética de Dostoiésvki, uma vez que é entendido não só no âmbito do enunciado, como também no âmbito das relações humanas. Para o eu se reconhecer, se afirmar, ele precisa da presença do outro. Não existe um eu acabado, monológico. O eu precisa do outro e o outro precisa do eu, trata-se de uma relação dialógica que vai se manifestar na linguagem através de diálogos.

\subsection{Síntese final}

Concluindo, a respeito das noções do Círculo de Bakhtin, pode-se dizer que:

I) A linguagem se dá através de enunciados que estão sempre associados a determinados gêneros do discurso;

II) Esses enunciados concretos, isto é, efetivamente realizados por um falante, são um elo na cadeia de comunicação verbal já que estão sempre colocados em diálogo, entendido no sentido restrito e amplo, e porque carregam marcas do discurso do outro manifestado nas diversas formas de transmissão do discurso alheio. Daí o caráter dialógico da linguagem;

III) Os gêneros do discurso dos quais esses enunciados fazem parte são determinados pela esfera de atividade humana que dá as condições específicas para se proferir tal ou qual enunciado; IV) Os gêneros do discurso, determinados pelas esferas de atividade humana, são compostos de enunciados que possuem um tema, um estilo e uma construção composicional específicos; V) A polifonia é o fenômeno de várias vozes, com pontos de vista diferentes se apresentando em um mesmo enunciado, manifestando um conflito e/ou uma polêmica. 


\section{A divulgação científica}

A Divulgação Científica (doravante DC) é uma atividade que envolve de um lado jornalistas, de outros cientistas e, de outro, o público-alvo. No meio desse triângulo, a linguagem. Para alguns autores, trata-se de uma linguagem 'traduzida', 'reformulada' ou 'decodificada', para outros autores, trata-se de uma linguagem 'formulada' em função do público-alvo. Analisaremos a DC a partir de três aspectos, todos fundamentais para os objetivos desta dissertação: (i) o papel social da DC; (ii) a linguagem da DC e (iii) a diferença entre a DC e o jornalismo científico.

\subsection{O papel social da divulgação científica}

Esta seção procura abordar as visões de jornalistas e lingüistas sobre o papel social que tem a DC na sociedade. Como se verá, para estes autores, a DC tem funções variadas, como, por exemplo, satisfazer a curiosidade de leitores sobre os fenômenos do Universo, oferecer dicas e conselhos na área da saúde e de informática e, até mesmo, compensar o que o campo da educação parece deixar a desejar em relação ao ensino da ciência.

Comecemos, em primeiro lugar, com vozes de jornalistas a esse respeito.

Segundo Victorelli (2003), em sua dissertação de mestrado intitulada “A ciência na gaveta. Um estudo da ciência versus divulgação científica",

desde que o ser humano olhou para o céu e encantou-se com o brilho das estrelas surgiram as perguntas: o que são esses pontos luminosos, por que tantos, como surgiram, para que servem? [...] A busca pelo conhecimento pode nos proporcionar melhores condições de sobrevivência, mas nada substitui uma extraordinária satisfação instintiva: nossa curiosidade! Queremos saber, conhecer, entender... (2003, p.19).

Esse autor, formado em jornalismo, diz aqui que, além dessa curiosidade natural dos homens que pode ser saciada pela DC, há uma DC que deve estar ao alcance dos homens para 
que estes, através das conquistas científicas (sejam elas da área da tecnologia, da medicina ou de qualquer outra), vivam mais e melhor.

Em sua tese, percebe-se que o autor está mais preocupado com o papel social da DC do que com a linguagem da DC. Vale citar mais um parágrafo de sua dissertação:

A divulgação científica reflete a preocupação para com a transformação do conhecimento, adquirido pelo ser humano, em processos e produtos capazes de melhorar a qualidade de vida de toda a sociedade brasileira e, no que couber, da humanidade. $\mathrm{O}$ que é, em essência, a sua principal finalidade. Sem essa divulgação, a Ciência se restringe aos próprios laboratórios que a geram, ou, então, as políticas científicas ficam trancafiadas em burocráticos gabinetes, sem chegar ao seu destino original (2003, p.101).

Diz o autor, logo em seguida, que o destino original é a sociedade. Entretanto, ele aponta para uma grande falha na DC: não há jornalistas preparados para tal atividade. Essa opinião é compartilhada com a do físico Ildeu Camargo Moreira que, em uma reportagem da Revista Pesquisa Fapesp de junho de 2004, afirma sobre a divulgação científica: “"mas a situação da educação científica e da popularização da ciência está muito distante do razoável', observa. Os problemas vão desde a formação de 'comunicadores' até a ausência de políticas para o tema" (2004, p.56).

Para Marcelo Leite, jornalista e editor de ciência da Folha de S. Paulo, os problemas da DC são ainda mais graves já que envolvem preocupantes situações financeiras. Em um artigo escrito para esse mesmo número da Revista Pesquisa Fapesp, ele afirma que, hoje em dia, embora a DC tenha crescido bastante, há sempre o medo do desemprego nesta área. Nas instituições em que não há essa crise, o que se tem feito não é propriamente DC, mas sim textos de paraciência $a^{9}$ : "um tipo de aconselhamento descartável, ainda que envernizado por pinceladas de ciência - notícias que se podem usar (e deitar fora) como lenços de papel” (2004, p.62). Para este jornalista, “enquanto não se criar uma rede de apoio social para a pesquisa científica como um valor cultural, e não apenas como fator de inovação e competitividade econômica, o jornalismo científico - e talvez o próprio empreendimento de pesquisa - continuará abandonado aos fluxos e refluxos da conjuntura" (2004, p.62).

Já Authier-Revuz (1998) foca-se mais na questão lingüística, embora não deixe de mencionar o papel social da DC. Para esta autora, a DC é uma atividade em que se disseminam os conhecimentos produzidos não para a própria comunidade científica, mas para o grande público. Segundo a autora, “[...] essa disseminação é feita fora da instituição escolar-universitária 
e não visa à formação de especialistas, isto é, não tem por objetivo estender a comunidade de origem" (1998, p.107) e não tem por objetivo aumentar o estado de conhecimento da ciência, mas sim do interlocutor.

Authier acha que há uma "ruptura cultural" entre a comunidade científica e o grande público uma vez que a primeira detém um poder ligado à competência e o segundo é privado desse poder. A DC, nesse caso, viria para remediar essa falta de saber do grande público. Entretanto, a autora deixa claro, no final do seu artigo, que a DC está aquém de um objetivo de "verdadeira formação" (1998, p.124).

Ao contrário, Zamboni (2001) pensa que se fosse apenas para romper essa distância cultural existente entre os cientistas e o grande público, bastaria "transformar em inteligível para muitos a linguagem hermética e difícil da ciência, entendida por apenas uns poucos" (2001, p.49). No entanto, Zamboni, apoiada em Chauí (1981), acha que esse procedimento (a difusão do conhecimento científico para o grande público) "apenas reforça o poder dos 'autorizados a saber"” (2001, p.50).

Orlandi (2001) acredita que a DC é um processo de "exterioridade" da ciência: "a ciência sai de si, sai de seu próprio meio para ocupar um lugar social e histórico no cotidiano dos sujeitos, ou seja, ela vai ser vista como afetando as coisas, a saber, no cotidiano da vida social" (2001, p.23). Segundo esta autora, a ciência no cotidiano das pessoas, através da DC, é uma necessidade na nossa sociedade. Entretanto, nem sempre essa relação entre a ciência e a sociedade é bem sucedida. Cabe ao jornalista científico dar qualidade a essa relação. Orlandi diz que o que se vê, a partir das formas lingüísticas encontradas no discurso da DC (mais detalhadas no próximo item), é que o leitor da ciência só vem a manter o lugar da ciência como aquele ainda distante da sociedade:

como leitor ele é posto na posição de quem participa de seu modo de produção e faz ressoar no social, sem vir a ser cientista. Ele é um leitor de ciência. Ao "compreender" a ciência, estabelece com ela uma relação - como massa crítica - que a impulsiona, que lhe dá uma forma, uma realidade social sensível, sem a qual a ciência não funciona (2001, p.26).

$\mathrm{Na}$ verdade, Orlandi acha mesmo que o leitor não deve virar um cientista, mas ele deve ao menos se relacionar com o lugar que a ciência ocupa para "poder ser crítico no processo de produção de ciência, já que a sociedade capitalista é definida pela sua capacidade de produzir ciência" (2001, p.28).

\footnotetext{
${ }^{9}$ Termo usado pelo próprio Marcelo Leite.
} 
Com essa breve exposição, observamos que o papel social da DC ideal seria aquele em que ela pudesse socializar o conhecimento produzido pelos cientistas de modo que a ciência servisse ao grande público de várias maneiras: seja para saciar curiosidades, seja para utilizar propriamente a ciência, seja para ter conhecimentos científicos, seja para que o leitor participe das decisões no processo de produção da ciência. Entretanto, como se verá, nem todos esses objetivos são alcançados pela DC, por razões várias. Dentre elas, podemos destacar o papel do Estado na política de financiamento da ciência que, ao privilegiar somente algumas áreas do saber, compromete os verdadeiros objetivos da DC listados acima.

\subsubsection{A divulgação científica e o Estado}

É comum pensarmos que, enquanto esfera de atividade, a ciência parece ser autônoma em relação as outras esferas e ao Estado, haja vista a imagem de distância dos cientistas, a linguagem considerada hermética etc. Esta não é, contudo, a opinião de Guimarães (2001) que acredita que a esfera da ciência é subordinado ao Estado e até mesmo à esfera da mídia. Trata-se, a meu ver, de um círculo vicioso que vem comprometendo pesquisas em certas áreas do conhecimento.

Guimarães diz que existe um antigo debate, no campo do saber, entre as áreas das Humanidades, como Filosofia, Literatura, Ciências Humanas etc. e as áreas das Ciências e Tecnologias. O Estado enviesa esse debate, apropria-se dele e o usa para justificar suas políticas de produção do conhecimento: "pode-se dizer, de um certo ponto de vista, que esta divisão significa uma concepção social pragmática e utilitária do conhecimento e que compreende quase exclusivamente as Ciências Exatas, da Vida e suas Tecnologias" (2001, p.76).

Uma vez que a mídia faz, majoritariamente, divulgação também dessas ciências ("ela funciona para dizer ao público o que é importante e o que não o é” (2001, p.78)), percebemos que mídia e Estado pensam a ciência a partir de um mesmo ponto de vista ideológico, embora a mídia aparente constituir também uma esfera de atividade autônoma. Na verdade, não se trata, na opinião de Guimarães, de autonomia ou dependência, mas sim de aliança: "a mídia, cujo discurso é determinado pelas mesmas condições históricas que determinam o discurso do Estado, tem suas 
formulações tomadas como externas à posição do Estado e, deste modo, as sustenta" (2001, p.78).

A situação se complica ainda mais quando percebemos que, além de restringir quais das áreas do saber deve ou não deve ser divulgada, também o "o quê" dessas áreas que será divulgado é posto em questão.

Em um outro artigo, Guimarães questiona sobre "o que é notícia para a grande imprensa quando se trata de ciência, de produção de conhecimento e tecnologia" (2001, p.13). Refletindo sobre o que enunciar na mídia ${ }^{10}$ e analisando um corpus composto de três revistas semanais com grande circulação nacional (Veja, Istoé e Época), ele constata que as notícias do desenvolvimento tecnológico e os cuidados com a vida humana são as notícias que predominam. Entretanto, ele frisa que essas notícias científicas não aparecem em uma seção própria de DC, mas atreladas a outras seções: “a cena da enunciação científica na enunciação jornalística é uma cena entre outras da notícia” (2001, p.19).

Vê-se, portanto, que o que é divulgado são os resultados da ciência e não o processo de produção de algum conhecimento científico. Apoiando-me nas análises sobre DC, verifica-se que o que vem sendo divulgado na grande mídia é justamente o resultado de uma pesquisa científica que tenha alguma utilidade no cotidiano das pessoas. Entretanto, ao contrário das revistas semanais analisadas por Guimarães, há outras que se dedicam exclusivamente à DC, como é o caso da Superinteressante, objeto desta dissertação. O espaço dedicado à ciência nesta revista é, portanto, diferente do espaço que verificamos nas revistas analisadas por Guimarães.

\subsection{A divulgação científica e a linguagem}

Aqui, abordaremos uma polêmica entre as idéias de Authier e de Zamboni. As duas igualmente trabalham com as noções de dialogismo e polifonia do Círculo de Bakhtin, mas divergem quanto à consideração do texto final de um trabalho de DC. Zamboni, além do Círculo de Bakhtin, tem a própria Auhtier como bibliografia fundamental e, inclusive, como motivadora de seu trabalho. Zamboni faz questão de explicitar isso na introdução de seu livro:

Fui seduzida a tomar a divulgação científica como objeto de minha tese de doutorado por Jacqueline Auhtier. Algum tempo depois, quando a conheci pessoalmente, fiquei mais seduzida por ela própria do que já o fora por seus escritos sobre a vulgarization scientifique. E quis o destino - que nem sempre nos move para o lugar ao qual

\footnotetext{
10 “Enunciar na mídia é enunciar segundo a interdiscursividade que determina as formulações da mídia, por mais que os jornalistas possam ainda afirmar que eles se pautam pela objetividade dos acontecimentos" (2001, p.15).
} 
queremos ir - que eu me tornasse dela uma leitora discordante, pelo menos no ponto em que seu entendimento sobre o que seja a divulgação científica incidiu numa interpretação fundada na idéia de que o discurso dessa prática é resultante de uma atividade de reformulação textual-discursiva de um discurso-fonte - o científico - em um discurso-segundo - o da vulgarização (2001, p.xvii).

Vejamos agora, mais detidamente, as idéias de Authier para então, depois, dar voz às ressalvas de Zamboni.

\subsubsection{A análise de Authier}

De fato, para Authier, uma vez que a função da DC é disseminar o saber científico para o grande público, isso só pode ser feito reformulando-se a linguagem. Já que se tem um novo receptor, não dotado dos saberes científicos, tem-se também um outro discurso. Nas palavras de Authier: "transmissão de um discurso existente em função de um novo receptor, a DC dá-se, então, imediatamente, como uma prática de reformulação de um discurso-fonte (doravante D1) em um discurso-segundo (doravante D2)" (1998, p.108).

Essa reformulação, segundo a autora, é explicitada através do quadro de enunciação e do fio do discurso. Diferentemente, por exemplo, da tradução de uma língua 1 para uma língua $2 \mathrm{em}$ que o trabalho de reformulação "pode se manter implícito ao ponto de se poder ignorar que D2 resulta de uma tradução" (1998, p.109). No caso do discurso reformulado da DC, "longe de esconder a maquinaria, ele a mostra sistematicamente [...]" (1998, p.109). Vejamos então, agora, como essa "maquinaria" é explicitada, segundo a autora.

\subsubsection{Reformulação explicitada no nível da enunciação}

Authier diz que nos textos de DC há uma dupla estrutura enunciativa uma vez que, esses textos, ao utilizarem o discurso relatado, acabam mostrando não só os interlocutores e o quadro de enunciação de D2 (o texto produto da DC) como também os interlocutores e o quadro de enunciação de D1 (o discurso-fonte). Entretanto, como se verá, não é só por utilizar o discurso relatado, mas também porque D1 é objeto de D2.

Segundo a autora, no D2 há a menção de D1 e sua enunciação já que D1 é justamente seu objeto explícito: um conhecimento científico. O texto D2 apóia-se explicitamente em D1 mostrando-o em sua enunciação. Se assim não fosse, isto é, se D2 quisesse ser um texto com apenas um quadro enunciativo, não levando em conta que se apoiou em outro texto, verificar-se- 
ia um texto típico de manual ou enciclopédia que não "mostram" o discurso-fonte que usaram para que seus textos fossem criados. Ao contrário, no texto da DC, há uma referência explícita a um discurso primeiro. Assim, segundo Authier, "D2 mostra a enunciação do D1 que ele pretende relatar, ao mesmo tempo em que se mostra em uma atividade de relato" (1998, p.114). Para Authier, quando há discurso relatado, há, inevitavelmente, uma dupla estrutura enunciativa. Entretanto, no caso dos textos de DC, essa dupla estrutura enunciativa reveste-se "de um caráter fortemente explícito" uma vez que, como foi dito, D1 é também objeto de D2.

\subsubsection{Reformulação explicitada no nível do fio do discurso}

Mais uma vez ao contrário de uma tradução de uma língua 1 para uma língua 2 em que se buscam equivalências, mas somente a língua 2 aparece, na DC

a colocação em contato de duas 'línguas' é o trabalho que é realizado por e no discurso segundo, que mostra a reformulação se fazendo e cujo fio, heterogêneo, passa de uma 'língua' à outra através de uma porção de operações que, exibidas aqui, não seriam notadas em uma tradução a não ser por traços eventuais (1998, p.115).

No texto da DC, as formas dos dois discursos (D1 e D2) aparecem. Authier chama as formas do D1 de científicas (C) e as formas do D2 de quotidianas (Q). Ora essas formas estão justapostas equivalendo-se metalingüisticamente, ora uma forma se sobrepõe à outra, sendo uma "o ponto de referência implícito a partir do qual se estabelece a distância metalingüística marcada sobre o outro" (1998, p.118).

Authier mostra através de trechos de artigos e dossiês das revistas Science et vie, Science et Avenir e do caderno "Ciências e Técnicas" do Le Monde que essas passagens, do discurso C ao $\mathrm{Q}$ ou vice-versa, acontecem a todo momento e que em momento algum este vaivém é suspenso em proveito de um dos dois; eles ocupam, nesta estrutura de contraponto, uma posição simétrica. Ora são as palavras científicas que estão entre aspas, ora são as palavras do cotidiano que estão entre aspas denotando o caráter de não pertencer ao texto. Essa é, inclusive, uma das funções das aspas como bem explica Authier: "as palavras entre aspas são marcadas como pertencentes a um discurso outro" (1998, p.118). Pois bem: quando é a palavra científica que está entre aspas, ela se mantém estranha à língua do leitor; quando é a palavra do cotidiano que está entre aspas, tem-se uma distância em relação à língua científica. 
Embora este vaivém, como foi dito acima, seja simétrico, entendido aqui como o fato de ocorrer a todo instante e como o fato de ocorrer alternadamente, isto acaba reforçando a distância entre a língua dos cientistas e a língua dos leigos uma vez que esta se apresenta como "uma imagem inexata e aproximada do original — e, portanto, das coisas" (1998, p.119) enquanto naquela há, muitas vezes, o prestígio das palavras americanas ou de origem intelectual reforçado ainda por abreviações misteriosas em iniciais.

Através dessas considerações sobre a reformulação explicitada, Authier afirma que o texto da DC é quase perfeito para exemplificar a noção de dialogismo desenvolvida pelo Círculo de Bakhtin: "o bilingüismo é aqui deliberado e afixado, no trabalho ostensivo sobre as palavras que coloca o enunciador-divulgador na posição metalingüística distanciada” (1998, p.121). Logo adiante, ela afirma que "os dois discursos mostrados como estranhos um ao outro, imagem no discurso do diálogo rompido entre a comunidade científica e a pública, são colocados em contato em um discurso um, na sua heterogeneidade, que institui a si próprio como um lugar de encontro - e não como um simples instrumento de transmissão" (1998, p.121). Assim, um discurso aparece no outro ou, nos termos de Bakhtin, o discurso do "eu" é marcado pelo discurso do “outro". No texto de DC, Authier afirma que "uma prática discursiva específica sai dele: um discurso explícito mostra-se, dubla o espetáculo que dá de si mesmo como discurso do dialogismo" (1998, p.121).

Concluindo a análise sobre a DC, Authier diz que, uma vez que a Ciência é representada e mostrada no texto da DC, esse texto acaba sendo uma imagem degradada do texto científico que, por sua vez, é um discurso absoluto, homogêneo e monológico. Já Orlandi (2001) acredita que o discurso da DC, por ter essa imagem degradada de que fala Authier, cria um paradoxo: ao mesmo tempo em que cria um efeito de estigmatização do texto científico, uma vez que ele fica rebaixado na DC, há "uma supervalorização da ciência formal e oficial distante de seus outros modos informais de circulação" (2001, p.23). Apoiada no que Maigueneau chama de “encenação", Orlandi diz que, quando aparecem as formas "segundo o cientista x", "especialistas reunidos em W chegaram à conclusão de que...etc" (2001, p.26), tem-se, por parte do leitor, duas sensações contraditórias: a sensação de estar perto da ciência, uma vez que "esta distância foi suturada, pela encenação" (2001, p.26), e a sensação de que a distância entre o leitor e a ciência permanece. Igualmente, o efeito de sentido desse discurso, como já foi dito, também é 
contraditório: "é reafirmada a importância da ciência, seja porque temos acesso a ela seja porque não conseguimos ter acesso a ela" (2001, p.26).

Voltando à análise de Authier, vemos que ela serve de base para a abordagem que Moirand (2000) faz no artigo Formas discursivas da difusão de saberes na mídia. Esta autora reafirma o que diz Authier sobre a heterogeneidade presente no texto de DC. Preocupada com as formas presentes na transmissão de saberes científicos, ela analisa um corpus sobre o caso da "vaca louca" em jornais da França (de março a dezembro de 1996), com base em dois critérios: os paradigmas reformuladores de um termo e a inscrição dos discursos outros no fio do enunciado.

Segundo esta autora, no discurso da mídia, sempre aparecem discursos de outro campo da atividade humana. É de acordo com o campo que um termo técnico da ciência vai ser reformulado. Isso faz lembrar o que diz Bakhtin sobre a neutralidade do signo lingüístico que adquire seu valor ideológico de acordo com o campo em que está inserido, como foi mostrado no capítulo 1.

Voltando à análise de Moirand, o termo 'prion' foi reformulado de várias maneiras segundo "se vai na direção de um ou outro pólo, de que dão conta os títulos dos artigos assim como os das rubricas nas quais eles aparecem" (2000, p.12). Este fato faz a autora questionar se o texto da DC quer realmente tornar o grande público mais sábio. Para ela, o discurso da DC quer “difundir uma imagem da mídia, que mostra assim estar ao corrente do 'estado de conhecimento" [...]" (2000, p.14). No entanto, esse discurso não torna o outro mais sábio uma vez que não explica o verdadeiro conteúdo da ciência, mas apenas a mostra: menciona-se "a comunidade dos especialistas não para que eles próprios expliquem mas para que eles sirvam da caução da explicação reformulada pelo jornalista" (2000, p.20).

Assim, quando aparecem outros tipos de texto que não a explicação científica ${ }^{11}$, mas a reformulação, o conselho, a definição, a exemplificação, vemos os outros discursos presentes no discurso da DC que acaba se revestindo de um caráter didático. Porém, segundo Moirand, essa didaticidade, explicitada através desses tipos de textos, é estereotipada, uma vez que não tem por

\footnotetext{
${ }^{11}$ Para a autora, o funcionamento da explicação tem diferentes funções, dentre elas: (i) elucidar ou esclarecer, isto é, responder à questão "o que é?” ou "o que isto significa?”; (ii) indicar um procedimento, isto é, responder à questão "como funciona?" ou "como se faz?"; (iii) dar razões, isto é, responder a um porquê subjacente. Esta última função seria a explicação científica propriamente dita, já que através dela "explica-se assim um fenômeno ou um processo, colocando em relação fatos, procurando as causas ou as conseqüências, entrando-se na construção de perspectivas de conhecimentos estabelecidos em outros lugares ou anteriormente" (p.20).
} 
finalidade tornar o grande público mais sábio, mas sim difundir crenças e "novos modos de relação com o saber" (2000, p.22), ou, em outros termos utilizados pela autora, o que temos é um fazer ver e não um fazer compreender (2000, p.11).

Já neste artigo $^{12}$, portanto, vemos uma posição diferente da de Authier que considera o discurso da DC como um trabalho de tradução ou reformulação.

Em Orlandi (2001), lemos que não podemos falar que a DC é um trabalho de tradução uma vez que esse discurso não trabalha com duas línguas diferentes, mas sim com dois discursos diferentes - o científico e o jornalístico. Porém, isso não quer dizer que o discurso da divulgação é a soma desses dois outros discursos, mas que ele "é uma articulação específica com efeitos particulares, que se produzem pela injunção a seu modo de circulação. Essa articulação, diferentemente do que tem sido dito (cf. Authier-Revuz, 1998), que a considera como tradução, é para mim um jogo complexo de interpretação" (2001, p.23). Como o discurso da DC está inscrito num outro campo de circulação que não o científico, a ciência vira mais informação do que conhecimento ou saber. Entretanto, o discurso da DC deve manter, segundo Orlandi, "efeitos de cientificidade" (2001, p.24). Trata-se de efeitos de cientificidade e não de conhecimento científico presente nesse discurso. Isso acontece porque, segundo a autora, não há como transpor sentidos de um discurso para outro, uma vez que um discurso está inserido em um campo que tem determinações e funções específicas e, além disso, interferem no discurso, afetando, conseqüentemente, nos sentidos. E como o campo do jornalismo é diferente do campo da ciência, os sentidos que a ciência possui são diferentes em um e outro campo. Vale citar Orlandi:

não se transportam sentidos de um discurso para outro. O jornalista científico ocupa uma posição sujeito específica determinada que não resulta pois de mera soma, nem substituição. Trata-se do que em discurso chamamos transferência, ou seja, é preciso que se produza um efeito metafórico pelo qual algo que significava de um modo, desliza para produzir efeitos de sentidos, diferentes. Desse ponto de vista não há equivalência entre o que é dito em uma ordem de discurso e na outra. Há transferência. Quando isso não é "bem feito" resulta em que há apenas "transporte" (e não transferência) de um sentido de um discurso para o outro o que resulta em perda, em caricatura. Por outro lado, o jornalista não estará "traduzindo" o discurso científico para o jornalístico, mas estará trabalhando no entremeio desses dois discursos, deslocando, portanto, também sua posição de jornalista. O discurso jornalístico não é mero receptáculo, ele é um meio, no sentido material. Quero com isto dizer que os meios não são indiferentes aos sentidos (2001, p.24).

Assim como Orlandi, Silva (2002) não acredita que a DC seja um trabalho de tradução, uma vez que o discurso jornalístico e o discurso científico são instituições com práticas histórico-

\footnotetext{
${ }^{12} \mathrm{O}$ artigo desta autora será retomado em capítulo posterior quando discutirei o tema da saúde.
} 
discursivas diferentes. Enquanto este dialoga com as diferentes posições disciplinares e teóricas e com o processo histórico da pesquisa, aquele se preocupa somente com o fato científico, resultando no que a autora chama de um "aplainamento" (2002, p.133) deste fato. Segundo ela, isso não acontece somente pela diferença que as duas atividades (ciência e jornalismo) têm em relação ao tempo de pesquisa e de realização de um trabalho, mas também pelos objetivos de uma e outra. A ciência tem como princípio "o compromisso com o próprio saber (o conhecimento que está sendo produzido) e com o fazer tecnológico" (2002, p.133). A mídia, por sua vez, está preocupada em fazer o público leigo ter acesso à ciência, mas, ao mesmo tempo, está preocupada em atrair cada vez mais leitores-consumidores, uma vez que está atrelada ao Mercado ${ }^{13}$. Para "falar" com esse grande público, com essa quantidade de leitores leigos, a mídia divulga o que ela acha que o público quer ler e, além disso, como já foi dito, fala só dos fatos científicos, mostrando apenas da ciência "seus resultados como produtos acabados"(2002, p.134). Esse é o motivo pelo qual Silva não considera a DC como um trabalho de tradução. Se o fosse, leríamos na DC um “conteúdo a saber"(2002, p.134) e não apenas resultados da ciência. Como só lemos resultados da ciência, os fatos científicos na DC tornam-se fatos da atualidade: "tende-se, nessa discursividade, ao apagamento da produção de sentido do fato científico enquanto tal, de modo a manter a enunciação do jornalismo concebida como uma prática discursiva sobre o fato da atualidade" (2002, p.134).

Como conseqüências deste discurso, produz-se uma dissimetria entre a imprensa e o público e, acrescenta-se, entre a ciência e o público, já que é a imprensa que vai escolher os fatos da ciência (resultados da ciência, fatos da atualidade) que ela quer transmitir e, além disso, esse fato mostrado como fato da atualidade, faz com que a autoridade da ciência fique estabelecida "pelo não questionamento do fato científico, que deve servir à disponibilização/apresentação, para a sociedade/público, como resultado acabado" (2002, p.135). Entretanto, analisando algumas reportagens da Superinteressante e da Galileu, a autora observa que o discurso da DC nessas reportagens às vezes extrapola os saberes da ciência:

as perguntas da Mídia são anteriores à reportagem e à resposta, portanto, que se busca na Ciência. [...] Se por outro lado a Ciência é essa autoridade inquestionável, por outro lado ela se mostra impotente aí, na busca de determinadas respostas que a dirigem e a extrapolam ao mesmo tempo (2002, p.145).

\footnotetext{
13 Silva atribui o caráter sensacionalista da mídia ao fato de ela estar atrelada ao Mercado: "a meu ver, o sensacionalismo é constitutivo da grande imprensa, justamente em função da sobreposição das determinações empresariais às determinações de uma democratização da informação e da cultura" (p.143).
} 
Esta seria, ao meu ver, mais uma razão para não considerar a DC como um trabalho de tradução.

Vejamos agora a análise de Zamboni que, ao apresentar argumentos bastante convincentes sobre o que vem então a ser a atividade da DC (afinal, tradução, reformulação ou formulação de um novo discurso?), também acaba dialogando e polemizando com Authier.

\subsubsection{A análise de Zamboni}

A principal tese que Zamboni defende é a de que, ao contrário do que diz Authier, a DC não é um trabalho de reformulação de um discurso, mas sim é uma formulação de um novo discurso.

Para defender essa hipótese, ela se foca, sobretudo, no pólo de recepção (o grande público) que é diferente do do discurso científico: "é preciso considerar, desde logo, que, alterando-se o lugar do destinatário, o lugar do enunciador também se altera, uma vez que, pelo princípio do dialogismo, exposto nas reflexões do círculo de Bakhtin, o discurso não existe independentemente daquele a quem está endereçado" (2001, p.62). Assim, se são outras as condições de produção, o discurso também é outro.

Zamboni acha que se o discurso da DC fosse apenas uma reformulação do discurso científico, ele ficaria num posicionamento desfavorável no campo científico, justamente como um discurso "degradado" da Ciência como disse Authier. Contudo, para Zamboni, o discurso da DC, sendo formulado e tendo um diferente destinatário, é um discurso totalmente novo que, "longe de ser degradado, empalidecido e esmaecido, é vivo, colorido e envolvente" (2001, p.85).

Vejamos agora as críticas que Zamboni faz a Authier quando esta diz que a DC é um trabalho de reformulação explicitado no quadro da enunciação e no fio do discurso.

\subsubsection{Quadro da enunciação}

Zamboni acha que a presença do discurso relatado está presente não única e exclusivamente nos textos da DC, mas também em vários outros tipos de textos: "a enunciação do discurso de outrem é tema recorrente nos mais diferentes gêneros discursivos e tipologias 
textuais" (2001, p.54). Assim sendo, para esta autora, o discurso relatado não é uma característica exclusiva da DC:

\begin{abstract}
se o discurso do "outro", o cientista, aí se faz presente, deve-se mais ao fato de ser o discurso de DC uma modalidade entre os demais discursos de transmissão, e menos a um traço de caracterização intrínseca e privilegiada. Acresça-se ainda o fato de que, por ser a DC um discurso de transmissão de informações especializadas, a voz dos cientistas e da ciência adquire uma feição argumentativa nesse gênero, porque imprime um caráter de autoridade e seriedade ao tratamento dado à notícia, para o que contribui, com certeza, a explícita nomeação dos personagens do mundo científico, com sua titulação, filiação a instituições, liderança de pesquisa etc (2001, p.56).
\end{abstract}

Além desta, há uma outra ressalva de Zamboni muito bem observada: quando a voz do cientista aparece no texto da DC, não se trata de uma fala de um discurso primeiro, o científico. Trata-se de uma fala já vulgarizada. Diz a autora que "sua fala (provavelmente obtida em entrevista) não reflete a voz da ciência, já é uma fala de divulgação, que exprime uma voz já vulgarizada" (2001, p.58).

Esses são os primeiros argumentos que Zamboni usa para ver na DC não uma atividade reformuladora, mas sim "o resultado de uma atividade que se desenvolveu em condições de produção inteiramente outras" (2001, p.59).

\title{
2.2.2.2 Fio do discurso
}

Aqui, mais uma vez, Zamboni atribui a não exclusividade da DC de ter dois discursos ou duas "línguas" colocadas em contato. Para ela, qualquer discurso de especialidade ao ser transformado num discurso de transmissão de informação opera desta maneira:

[...]direcionado a uma outra audiência, o discurso da especialidade é submetido a um tratamento "explicativo" ou "simplificador" que se efetua, quase invariavelmente, sobre o componente terminológico, mas pode abranger também os cenários e os agentes envolvidos no processo de sua produção (2001, p.70).

Zamboni acredita ainda que explicar as formas de $\mathrm{C}$ através das formas de Q não é um trabalho de reformulação simples como ocorre, por exemplo, na tradução, na paráfrase, em que "há de comum o movimento de um discurso em direção a um outro, a produção do outro a partir do um, sob a égide da "equivalência"” (2001, p.75). Apoiando-se em Peytard (1984), a autora diz que nem tudo é passível de reformulação num texto científico, haja vista ao seu alto grau de conceptualização (os axiomas, os teoremas, as operações do discurso matemático) quase impossível de ser reformulado. Assim, a reformulação aqui não será nunca equivalente como no 
caso da tradução. Diz Peytard que, no caso da tradução, transforma-se o primeiro objeto num segundo objeto semelhante a ele (A $\left.A^{\prime}\right)$. No caso da DC, transforma-se o primeiro objeto num segundo objeto diferente (A $\quad$ B). Esse é mais um argumento que Zamboni usa para defender sua tese de que a DC é uma atividade de formulação de um novo discurso. Orlandi (2001) também faz considerações a respeito das reformulações. Para ela, no discurso da DC, passa-se da metalinguagem para a terminologia, cujo efeito de sentido é justamente o de dar uma “"ancoragem' científica” (2001, p.27). Esse é um dos efeitos de cientificidade que o discurso da DC carrega:

o que seria, numa formulação científica, pela sua metalinguagem específica, significado na direção da produção da ciência é deslocado para uma terminologia que permite que a ciência circule, que se entre assim em um "processo de transmissão" (2001, p.27).

Cria-se também, ao se substituir a metalinguagem pela terminologia, um efeito de didaticidade porque os termos que são sentidos como familiares ${ }^{14}$ parecem substituir os termos científicos. Entretanto, ao usar termos, o discurso da divulgação, querendo possuir 'efeitos de cientificidade' acaba perdendo-os, já que foge a uma característica da ciência: a objetividade. Orlandi diz que "quanto maior a preocupação terminológica mais fora está o discurso do jornalista, menos próximo do processo" (2001, p.27). Esta autora acredita que o bom resultado da DC seria aquele em que se mostrasse mais o processo da ciência e menos sua representação. Só assim o leitor estaria habilitado a se colocar criticamente no processo de produção da ciência. E só assim é que haveria de fato uma socialização do conhecimento.

\subsubsection{A subjetividade mostrada}

Zamboni acredita que em qualquer texto há fortemente marcada a presença do trabalho de um "eu”. Ela não divide a mesma opinião de Authier quando esta diz que na DC há uma heterogeneidade mostrada já que o discurso do "outro" está presente. Na verdade, Zamboni acha sim que há um "outro" presente, mas quem domina o discurso é o "eu”. Esta autora comenta que, em certo momento, a Análise do Discurso foi influenciada por Althusser e Freud e que este fato fez com que se acreditasse em "um sujeito completamente assujeitado, produto puro das

\footnotetext{
${ }^{14}$ Orlandi diz que alguns dos processos para tornar o termo familiar são: as descrições, os sinônimos, as perífrases, as equivalências etc. (p.27).
} 
estruturas, a quem resta apenas a ilusão de quem fala, já que é atravessado pela ideologia e pelo inconsciente" (2001, p.8).

A autora se apóia nas idéias de Possenti (1996) para afirmar que o sujeito é consciente sim do que fala e opera um trabalho não apenas com a língua, mas sobre a língua: "torna-se imprescindível, portanto, admitir o trabalho do 'eu', que, tal como o 'outro', deixa marcas de sua intervenção na construção e formulação do discurso da divulgação científica” (2001, p.21). Zamboni, como foi dito, não exclui a participação do 'outro' no discurso, mas ela diz que "se a emergência do 'outro' é condição inegável da existência de todo discurso, a presença do 'eu’ é a condição prévia da enunciação na qual aparece o "outro"” (2001, p.21).

Deste modo, nos textos da DC, além de uma heterogeneidade mostrada, há uma subjetividade mostrada, já que a presença do 'eu' é facilmente detectada: ao levar em conta um outro interlocutor, ao reformular um termo de alta densidade de conceptualização etc.

\subsubsection{DC como um gênero de discurso}

Depois de fazer essa longa argumentação para mostrar que a DC é mais um trabalho de formulação de um novo texto do que de reformulação, Zamboni defende a hipótese de a DC ser um gênero do discurso:

[...] a divulgação científica constitui um gênero particular no conjunto dos demais discursos das diferentes áreas de funcionamento da linguagem, sujeito, portanto, a condições de produção bastante diversas daquelas que cercam, ao menos, o discurso científico (2001, p.81).

Quando fala em "condições de produção bastante diversas", Zamboni quer dizer que o destinatário da DC é outro e, uma vez que isso acontece, apoiando-se em Bakhtin, mudam-se também a composição e o estilo do gênero. Além disso, como já foi dito, o texto da DC não é um “equivalente de menor valor" do texto do discurso científico, como se fosse um texto pertencente à esfera da ciência. A DC faz parte de outro campo e, portanto,

se é constitutivo do discurso estar voltado para o destinatário, e se esse destinatário se concebe diferentemente em diferentes condições de produção, tal como ocorre com os destinatários do discurso científico e com os do discurso da divulgação científica, é lícito concluirmos que estamos diante de dois gêneros discursivos distintos, e mais, colocados em funcionamento em campos discursivos distintos (2001, p.94).

Considerar a DC como um gênero de discurso vai contra as considerações de Bakhtin, já que este afirma que utilizamo-nos da linguagem através dos vários gêneros do discurso os quais 
fazem parte de determinada esfera da atividade humana. Cada gênero possui um tema, um estilo e uma forma composicional próprios resultando em tipos relativamente estáveis de enunciado, dando ao gênero um caráter verbal (essa estabilidade do enunciado) e um caráter extraverbal (pelo fato de fazer parte de determinada esfera). Penso que Zamboni, de certa forma, misturou as duas noções (gênero do discurso e esfera da atividade humana) para considerar a DC como um gênero do discurso. Acredito que a DC não constitui uma esfera de atividade humana, mas é possível dizer que a DC é uma prática discursiva que se realiza em diferentes esferas, valendo-se dos diferentes gêneros que cada esfera possui como, por exemplo, o gênero reportagem que pertence à esfera do jornalismo, o gênero livro didático que pertence à esfera da educação etc.

\subsection{Divulgação científica x Jornalismo científico}

Novamente aqui a noção de esfera faz-se necessária para entendermos essa diferença. Se o jornalismo científico faz parte da esfera do jornalismo, qual seria a esfera do qual faz parte a DC?

Em seu livro, embora defenda a idéia de que a DC é um gênero, Zamboni argumenta que a DC está no campo de transmissão de informações (2001, p.64) e que é mais amplo do que o jornalismo científico uma vez que possui uma maior diversidade de textos. Eu diria: a DC se vale de uma maior diversidade de gêneros.

Entretanto, parece que o jornalismo científico também se encontra nesse "campo de transmissão de informações", uma vez que é "parte" da divulgação científica. O jornalismo científico, segundo o jornalista Bueno (1984),

se constitui em um caso particular de divulgação científica e refere-se a processos,
estratégias e mecanismos para veiculação de fatos que se situam no campo da ciência e
da tecnologia. Desempenha funções econômicas, político-ideológicas e sócio-culturais
importantes e viabiliza-se, na prática, através de um conjunto diversificado de gêneros
jornalísticos (1984, p.11).

Este autor realiza um trabalho detalhado em sua tese de doutorado, acabando por diferenciar conceitualmente não só a DC e o jornalismo científico como também a disseminação e a difusão. Para ele, "cada um desses conceitos assume contornos próprios, ainda que se articulem num terreno comum: processos, estratégias, técnicas e mecanismos de veiculação de fatos e de informação que se situam no universo da ciência e da tecnologia" (1984, p.13).

Assim sendo, considera-se difusão "todo e qualquer processo ou recurso utilizado para a veiculação de informações científicas e tecnológicas" (1984, p.14). A difusão, portanto, abrange a 
DC, o jornalismo científico e a disseminação. Esta última trata da "transferência de informações científicas e tecnológicas, transcritas em códigos especializados, a um público seleto, formado por especialistas" (1984, p.16). Temos aqui, portanto, um caso de difusão científica feita para pares. Já a DC seria um tipo de difusão feita não para pares, mas para o grande público. Nas palavras de Bueno: "a divulgação científica compreende a utilização de recursos, técnicas e processos para a veiculação de informações científicas e tecnológicas ao público em geral" (1984, p.18).

Confirmando a idéia de Zamboni quando diz que a DC possui uma maior diversidade de textos, podemos ler em Bueno:

é importante frisar que a divulgação científica não se restringe ao campo da imprensa.
Inclui os jornais e revistas, mas também livros didáticos, as aulas de ciências do $2^{\circ}$ grau,
os cursos de extensão para não-especialistas, as estórias em quadrinhos, os suplementos
infantis, muitos dos folhetos utilizados na prática de extensão rural ou em campanhas de
educação voltadas, por exemplo, para as áreas de higiene e saúde, os fascículos
produzidos por grandes editoras, documentários, programas especiais de rádio e
televisão etc (1984, p.19).

O jornalismo científico, por sua vez, vincula-se ao conceito de $\mathrm{DC}^{15}$, mas limita-se aos gêneros da imprensa: notícia, reportagem, entrevista, artigo, resenha, coluna etc.

Além disso, é importante ainda ressaltar que Bueno incorpora as Ciências Humanas, as técnicas e os processos mais simples também como objeto do jornalismo científico.

Esta divisão conceitual é importante para os propósitos desta dissertação uma vez que o corpus é composto de reportagens de capa de uma revista de jornalismo científico, a Superinteressante. Inserida na esfera do jornalismo científico, já é possível excluirmos algumas características dos textos dessa revista: não é voltada para pares e especialistas, mas sim para o grande público; os gêneros não serão tão variados quanto os da DC, mas se restringem aos gêneros presentes no campo da imprensa.

\footnotetext{
${ }^{15}$ Segundo o autor, "os objetivos do jornalista científico e do divulgador científico não são muito diferentes: em termos gerais, ambos se preocupam em transferir aos não-iniciados informações especializadas de natureza científica e tecnológica" $(1984$, p.20)
} 


\section{(3)}

\section{Metodologia}

O corpus deste projeto de pesquisa é um recorte da seleção feita por minha orientadora em seu projeto maior $O$ funcionamento de formas do português em gêneros de transmissão de saberes. Ela considera para a construção de seu corpus tanto os gêneros explicitamente didáticos - livros didáticos e manuais - quanto os gêneros de informação - artigos de divulgação científica de revistas impressas especializadas e até mesmo em revistas virtuais, reportagens de DC em jornais e reportagens sob outras rubricas tais como saúde, cotidiano, meio ambiente, que se utilizam de procedimentos de divulgação de saberes científicos.

Segundo Maingueneau (1997, apud GRILLO 2003), a noção de corpus é constituída de diferentes níveis:

a) O corpus máximo depende da variável que permite agrupar os enunciados: por exemplo, todos os enunciados que pertencem a um gênero do discurso determinado ou que são produzidos a partir de tal posição ideológica. A maior parte do tempo esse corpus máximo não é delimitável.

b) O corpus delimitado: sobre o corpus máximo, o analista circunscreve um conjunto de enunciados, em função do objetivo de sua pesquisa.

c) O corpus elaborado: a partir das hipóteses de trabalho que ele constrói, o pesquisador define um programa de análise e deve extrair do corpus delimitado um ou vários corpora elaborados (certos episódios narrativos, enunciados de tal estrutura sintática, um conjunto de passagens organizadas em torno de um conector argumentativo etc).

Para a construção de meu corpus máximo, considerei, dentre as publicações na área de DC do mercado editorial brasileiro, apenas uma revista impressa especializada. Trata-se da revista Superinteressante. 
A escolha dessa publicação dentre as outras se deu principalmente por dois motivos: em primeiro lugar, por ela ser a revista impressa de reportagens de jornalismo científico brasileira que tem a maior tiragem (quase 500.000 exemplares por mês); em segundo lugar, por ela ser a mais antiga produzida por uma editora comercial - sua primeira edição data de outubro de 1987. O fato de ela ser uma revista de uma editora comercial pode trazer implicações e contribuições para a análise dos dados. Ao contrário da Revista Pesquisa Fapesp que, apesar de ser vendida nas bancas, é financiada por uma agência de fomento à pesquisa científica (sendo, além disso, enviada gratuitamente a mais de 23,5 mil pesquisadores, bolsistas ou assessores da FAPESP), a Superinteressante pertence à Editora Abril, uma das maiores e mais importantes do País.

Em seguida, o meu corpus delimitado foi construído com base em três critérios: $1^{\circ}$ ) o gênero escolhido para a análise são as reportagens de capa da Superinteressante; $2^{\circ}$ ) essas reportagens têm como tema a saúde; $3^{\circ}$ ) a seleção das revistas foi feita diacronicamente.

O gênero escolhido se deve principalmente a dois fatores que se complementam: em primeiro lugar, as reportagens de capa têm o maior destaque na revista e, em segundo lugar e conseqüentemente, elas têm maior atenção não só por parte dos leitores como também dos produtores de tal gênero.

O tema da saúde foi escolhido já que atinge um número maior de leitores, isto é, este tema concentra estratégias que influenciam o dia-a-dia das pessoas. Isto quer dizer que o tempo para se dedicar à leitura de revistas parece ser gasto preferencialmente em reportagens que tenham alguma utilidade na vida e que não sejam 'meras curiosidades'. Em um outro meio de comunicação, como a televisão, por exemplo, podemos constatar também a preferência pelo tema da saúde, por parte dos divulgadores. O jornalista e editor-chefe do Jornal Nacional Willian Bonner, em uma reportagem da Revista Pesquisa Fapesp em Junho de 2004 acerca da divulgação científica, diz: "se fizéssemos uma análise de tudo que foi ao ar nos últimos anos, certamente temas ligados à saúde seriam a maioria (...)” (2004, p.50). Segundo a reportagem, "Bonner reconhece que saúde é mesmo o tema mais fácil de emplacar na televisão, em particular notícias sobre novos caminhos para a cura de doenças" (2004, p.50).

Um outro motivo para essa escolha é que as reportagens que tratam deste tema não são apenas expostas e explicadas. Pode haver, além dessa exposição e desse didatismo, um caráter aconselhador que não se verifica nas reportagens de outros temas de DC como astronomia, descobertas tecnológicas etc. 
Em relação ao terceiro critério utilizado na construção do corpus, considerando que a primeira edição da revista é de 1987, escolhi seus dois primeiros anos 1987/1988 como o ponto de partida para a análise. Depois, 1995/1996 figurando como o meio da existência da revista, e, finalmente 2002/2003 como os anos mais recentes. Esses três períodos justificam-se para que se possa perceber a evolução da abordagem bem como a freqüência deste tema na história da revista.

Ao pesquisar esses períodos, entretanto, algumas modificações se fizeram necessárias e merecem ser registradas:

$1^{\text {a) }}$ a primeira edição da revista é de outubro de 1987. As reportagens de capa de outubro, novembro e dezembro deste ano não trataram do tema da saúde obrigando-me a considerar, então, o ano de 1989, juntamente com o ano de 1988, como os dois primeiros anos;

$2^{\text {a }) ~ n o ~ s e g u n d o ~ p e r i ́ o d o, ~ s o ́ ~ o ~ a n o ~ d e ~} 1995$ possui reportagens de capa com o tema da saúde; em 1996, não há nenhuma. Portanto, resolvi considerar o ano de 1994. Mais uma vez, nenhuma reportagem de capa foi encontrada. Assim, a saída foi considerar o ano de 1997 figurando, juntamente com o ano de 1995, como o meio do recorte diacrônico que estou considerando aqui.

Deste modo, delimitados os critérios de construção do corpus, as revistas selecionadas para a análise estão nas tabelas abaixo:

\section{Tabela 1}

$1^{\circ}$ período 1988/1989

\begin{tabular}{|l|l|l|}
\hline DATA & NÚMERO & TÍTULO DA REPORTAGEM DE CAPA \\
\hline Mar/1988 & 6 & Dor. Este tormento pode acabar \\
\hline Out/1988 & 13 & Medicina chinesa. Ciência do equilíbrio \\
\hline Mai/1989 & 20 & Gordos \& Magros. Quem é quem na balança \\
\hline Nov/1989 & 26 & Sangue. Um mergulho neste precioso líquido \\
\hline
\end{tabular}

\section{Tabela 2}

$2^{\circ}$ período 1995/1997

\begin{tabular}{|l|l|l|}
\hline DATA & NÚMERO & TÍTULO DA REPORTAGEM DE CAPA \\
\hline Mar/1995 & 90 & Vitaminas. Ou você toma ou você perde \\
\hline Ago/1995 & 95 & Maconha. Um remédio proibido? \\
\hline Jan/1997 & 112 & $\begin{array}{l}\text { Cosméticos científicos. Agora a beleza virou } \\
\text { assunto dos cientistas. }\end{array}$ \\
\hline Abr/1997 & 115 & O veneno do bem. Cientistas brasileiros \\
\hline
\end{tabular}




\begin{tabular}{|l|l|l|}
\hline & & $\begin{array}{l}\text { surpreendem o mundo com remédios de } \\
\text { serpentes. }\end{array}$ \\
\hline Jul/1997 & 118 & $\begin{array}{l}\text { Na mira do mosquito assassino. Ele espalha a } \\
\text { malária e mata 1,5 milhão de pessoas por } \\
\text { ano. Agora, pesquisadores brasileiros } \\
\text { lideram a corrida mundial pela vacina. }\end{array}$ \\
\hline Set/1997 & 120 & $\begin{array}{l}\text { No fundo do coração. Uma nova técnica } \\
\text { brasileira revoluciona as cirurgias cardíacas. }\end{array}$ \\
\hline Nov/1997 122 & $\begin{array}{l}\text { O curativo genético. A Medicina já começou } \\
\text { sua maior revolução. Em breve, com um } \\
\text { simples toque no DNA do paciente, ela será } \\
\text { capaz de curar. }\end{array}$ \\
\hline
\end{tabular}

Tabela 3

$3^{\circ}$ período 2002/2003

\begin{tabular}{|l|l|l|}
\hline DATA & NÚMERO & TÍTULO DA REPORTAGEM DE CAPA \\
\hline Abr/2002 & 175 & $\begin{array}{l}\text { Deveríamos parar de comer carne? Carne dá } \\
\text { câncer? Dá para viver só de vegetais? Seu } \\
\text { corpo foi feito para digerir carne? Saiba o } \\
\text { que é fato o que é lenda no debate sobre o } \\
\text { vegetarianismo. }\end{array}$ \\
\hline Ago/2002 & 179 & $\begin{array}{l}\text { Maconha. Por que é proibida? O que } \\
\text { aconteceria se fosse legalizada? Como a } \\
\text { ciência aumentou seus efeitos? Faz mal à } \\
\text { saúde? }\end{array}$ \\
\hline Set/2002 & 180 & $\begin{array}{l}\text { Diabete. Tudo o que você precisa saber para } \\
\text { não desenvolver a sua. Há 350 milhões de } \\
\text { diabéticos no mundo. Metade ainda não sabe } \\
\text { que está doente. Talvez você seja um deles. }\end{array}$ \\
\hline Nov/2002 & 182 & $\begin{array}{l}\text { A ciência de ser saudável. Novos estudos } \\
\text { mostram que ter saúde é mais fácil e barato } \\
\text { do que você imagina. Saiba por que cada vez } \\
\text { mais pessoas estão trocando os remédios por } \\
\text { alimentos que evitam doenças; exercícios } \\
\text { que estimulam a cura; atividades que } \\
\text { prolongam a vida. }\end{array}$ \\
\hline Fev/2003 & 185 & $\begin{array}{l}\text { Precisamos de tanto remédio? O consumo } \\
\text { indiscriminado - e crescente de de } \\
\text { medicamentos, aliado à voracidade } \\
\text { comercial dos grandes laboratórios e à } \\
\text { irresponsabilidade de muitos médicos, cria } \\
\text { um novo tipo de dependente: o viciado em } \\
\text { drogas legais. Você é um deles? }\end{array}$ \\
\hline Out/2003 & 193 & \begin{tabular}{l} 
Meditação. O que é, para que serve, o que a \\
\hline
\end{tabular} \\
\hline
\end{tabular}




\begin{tabular}{|l|l|}
\hline & $\begin{array}{l}\text { ciência diz a respeito e por que tanta gente } \\
\text { está praticando. }\end{array}$ \\
\hline
\end{tabular}

As categorias formais que apontam para procedimentos discursivos que serão analisados nas reportagens são as seguintes:

\section{$\left.1^{\circ}\right)$ Peritexto}

- captação do leitor por meio do peritexto. Observarei como se dá a articulação entre os aspectos verbais do peritexto (os títulos) e os aspectos não-verbais (as imagens);

\section{$\left.2^{\circ}\right)$ Texto}

- procedimentos de mediação do discurso científico por meio da apreensão e transmissão do discurso alheio, baseados na tipologia feita por Bakhtin em Marxismo e Filosofia da Linguagem. 


\section{Análise do primeiro período}

Como se viu no capítulo anterior, os anos de 1988 e 1989 compõem o primeiro período a ser analisado nesta dissertação. As duas categorias de análise, a saber, alguns elementos do peritexto e o discurso citado foram escolhidas em razão de sua natureza explicitamente dialógica. Os títulos dialogam com o leitor, tentando captá-lo para a leitura; os discursos citados, em reportagens de DC, dialogam não só com o leitor, mas também com vozes de outras esferas da atividade humana.

\subsection{Os elementos do peritexto}

Dentre os elementos da forma composicional do gênero reportagem de capa, elegi os títulos para analisar por duas razões principais: a primeira é pelo fato de os títulos das reportagens conterem elementos lingüísticos que, dadas as especificidades da minha área, podem ser mais bem analisadas que os aspectos não-verbais como cores, disposição dos elementos na capa, tamanho da fonte ${ }^{16}$ etc. Ressalto, no entanto, que analisarei as imagens que acompanham os títulos das reportagens na capa, uma vez que esses elementos também fazem parte desse gênero. A segunda razão justifica-se pelo fato de os títulos serem a primeira forma de diálogo com o leitor e, portanto, a primeira forma de abordar um possível consumidor, já que a revista analisada, pertencente ao Grupo Abril, tem a venda como foco principal.

Para Jean-Michel Adam/Ute Heidmann (2004), o título é um dos elementos que compõe o plano peritextual, definido como as fronteiras do texto com outros textos e com o próprio leitor, que ao lê-lo na capa saberá que se trata da reportagem mais importante da revista. O plano

\footnotetext{
${ }^{16}$ Não deixo de considerar, no entanto, o fato de que o título da reportagem que possui o tamanho da fonte maior denota a reportagem principal, a reportagem de capa, contribuindo para a produção do tema.
} 
peritextual traz, ainda, as enunciações do sub-título, da dedicatória, do prefácio, da capa ${ }^{17}$. Tratase de um "aparelho de enquadramento do texto que está em estreita ligação com a genericidade" $" 18$.

Grillo (2004), ao analisar os títulos da Folha de S.Paulo e os do Estado de S.Paulo, aponta para a importância dos títulos uma vez que eles podem ser o único enunciado que o leitor lê. Depois de analisar os manuais de redação dos dois jornais, a autora diz que "as duas principais funções do título são: representar uma fonte de informação autônoma para o leitor e captá-lo para a leitura do texto" (2004, p.98).

Veremos, neste capítulo e nos seguintes, através de quais recursos lingüísticos presentes nos títulos, estas reportagens se valem para captar o leitor-consumidor e como se revela a síntese temática, ou seja, a partir de quais recursos lingüísticos o tema é construído.

A outra categoria de análise é a presença de discurso citado. Valho-me de obras do círculo de Bakhtin, minha referência maior, para dar conta desse fenômeno.

\subsection{A noção de discurso citado para o Círculo de Bakhtin}

Em primeiro lugar, na obra Marxismo e filosofia da linguagem (1929/2004), em que os autores dedicam toda a terceira parte para discorrer sobre as formas de enunciação nas construções sintáticas, vemos uma preocupação no estudo e na análise do discurso de outrem. Dizem os autores que o "discurso citado é o discurso no discurso, a enunciação na enunciação, mas é, ao mesmo tempo, um discurso sobre o discurso, uma enunciação sobre a enunciação" (1929/2004, p.144). Assim, ao integrar o discurso do outro no discurso do eu, ou melhor, integrar o discurso citado no discurso narrativo, haverá mais ou menos conservação do discurso citado. $\mathrm{O}$ jogo com as preposições "no" e "sobre" revela dois aspectos constitutivos do discurso citado na perspectiva de Bakhtin/Voloshinov: há uma falha alheia presente no discurso citado, mas há também um diálogo sobre essa fala, uma vez que, por meio dos verbos de elocução, por exemplo, essa fala será interpretada de uma ou outra maneira pelo leitor. Isto porque o discurso citado e o contexto de transmissão constituem uma inter-relação dinâmica por causa de três motivos principais:

\footnotetext{
17 Para Genette (1987), o conceito de paratexto é mais amplo do que o de peritexto, uma vez que inclui os comentários que um autor faz de seu próprio texto.

18 ، [...] l'appareil d'encadrement du texte est éditorialement en étroit rapport avec la généricité” (p.68).
} 
1) a estrutura de um enunciado que contém um discurso citado deve "ajustar-se" sintática, estilística e composicionalmente para "abrigar" esse discurso:

a enunciação do narrador, tendo integrado na sua composição uma outra enunciação, elabora regras sintáticas, estilísticas e composicionais para assimilá-las parcialmente, para associá-la à sua própria unidade sintática, estilística e composicional, embora conservando, pelo menos sob uma forma rudimentar, a autonomia primitiva do discurso de outrem, sem o que ele não poderia ser completamente apreendido (1929/2004, p.145).

Assim, o contexto que incorpora o discurso citado forma com ele uma relação dinâmica que interfere na apreensão deste último;

2) essa inter-relação dinâmica é também conseqüência do fato de haver uma terceira pessoa para a qual o discurso citado está sendo transmitido. Segundo os autores, essa orientação para uma terceira pessoa é importante uma vez que ela revela e reforça a influência das forças sociais que agem sobre o modo de se apreender um discurso;

3) a inter-relação dinâmica, presente em um contexto narrativo que carrega citações, acaba revelando também a inter-relação social dos indivíduos na comunicação ideológica verbal. Assim sendo, as formas da língua que carregam o discurso de outrem revelariam também os contextos sociais em que aquele discurso foi produzido e recebido. Portanto, falar das formas dessa dinâmica é falar também das tendências sociais estáveis de uma comunidade, uma vez que, para os autores, a língua "não é o reflexo das hesitações subjetivo-psicológicas, mas das relações sociais estáveis dos falantes" (1929/2004, p.147).

E quais seriam as formas da língua quando um contexto narrativo quisesse carregar um discurso citado? Segundo os autores, há duas orientações na dinâmica dessa inter-relação. Tratase do estilo linear, cuja tendência principal é "criar contornos exteriores nítidos à volta do discurso citado, correspondendo a uma fraqueza do fator individual interno" $(2004$, p.150) e do estilo pictórico, cuja tendência é "atenuar os contornos exteriores nítidos da palavra de outrem" (1929/2004, p.150).

Os autores analisam algumas variantes de dois esquemas da língua russa, o discurso direto e o discurso indireto. Aqui, estou adaptando esses esquemas à língua portuguesa, sem deixar de levar em conta a afirmação dos autores em relação aos efeitos de sentido e orientação de interpretação que causa a presença do discurso citado nos textos. Assim, na orientação linear, 
encontramos o discurso indireto analisador do conteúdo. Neste tipo, embora os traços sintáticos do discurso citado não fiquem tão conservados, há uma conservação de seu conteúdo temático que se distancia nitidamente das palavras do contexto narrativo. Dizem os autores que "a tendência a tematizar o discurso de outrem é incontestavelmente inerente a essa variante, e assim ela preserva a integridade e a autonomia da enunciação, não tanto em termos sintáticos mas em termos semânticos (...)" (1929/2004, p.161). Esse tipo de variante verifica-se em contextos que querem destacar um autor que tenha uma forte posição sobre determinado assunto. Cabe ao contexto narrativo expor esse autor e delimitar bem seu discurso. No discurso indireto analisador da expressão há uma integração, no discurso indireto, das palavras e do modo de dizer do autor do discurso citado: “essas palavras e maneiras de dizer são introduzidas de tal forma que sua especificidade, sua subjetividade, seu caráter típico são claramente percebidos" (1929/2004, p.162). Normalmente, essas palavras e/ou expressões do outro são colocadas entre aspas ou aparecem em itálico, mostrando claramente para o leitor que se trata de outra "cor", diferente do contexto narrativo, embora seja este o responsável pela "aparição estranha" dessas palavras. Mesmo assim, a individualidade do autor do discurso citado é posta em relevo, formando uma imagem. Igualmente o discurso direto preparado seguido de discurso indireto, em que "a subjetividade do discurso aparece com maior nitidez e no sentido que convém ao autor" (1929/2004, p.163), pertence à orientação linear.

O estilo pictórico abrange mais tipos do que o linear. Encontramos os seguintes tipos para ilustrar este estilo:

1) discurso direto preparado seguido de discurso indireto livre - é o caso em que "os temas básicos do discurso direto que virá são antecipados pelo contexto e coloridos pelas entoações do autor" (1929/2004, p.166), gerando um enfraquecimento das fronteiras do discurso citado. Bakhtin/Voloshinov dizem que, nesta variante, o fundo perceptivo pertence metade ao contexto narrativo e metade ao discurso citado;

2) discurso direto esvaziado - essa variante não se preocupa tanto com a carga semântica das palavras quanto com sua significação caracterizadora do autor do discurso citado, sua tonalidade e seu valor típico. Os autores exemplificam essa variante com a situação de rirmos de um personagem cômico apenas por sua caracterização (maquiagem, roupa e atitude) e não com o sentido de suas palavras; 
3) discurso direto antecipado e disseminado - semelhantemente ao discurso direto preparado, aqui também há uma preparação e uma antecipação do tema do discurso citado. A diferença é que, neste caso, as "cores" e as entoações do discurso citado assemelham-se ao contexto narrativo, embora ainda haja conservação das entoações próprias deste contexto. É como se várias das expressões presentes no contexto narrativo pudessem ser colocadas entre aspas porque caberiam perfeitamente na fala do autor do discurso citado. Assim, cada uma dessas palavras pertence simultaneamente ao contexto narrativo e ao autor do discurso citado. Dizem Bakhtin/Voloshinov que "estamos em presença de um exemplo típico de um fenômeno lingüístico raramente estudado - as interferências de discurso" (1929/2004, p.169).

Há, ainda, o discurso direto retórico que, embora os autores classifiquem-na como pertencente ao estilo linear, não há como não ver um cruzamento de vozes no mesmo enunciado e, portanto, um enfraquecimento das fronteiras entre contexto narrativo e discurso citado quando ocorre esse tipo de discurso. Nas palavras dos próprios autores:

Há nas relações sociais aquilo que é chamado a pergunta retórica, ou a exclamação retórica. Alguns casos desse fenômeno são especialmente interessantes por causa do problema da sua localização contextual. Eles situam-se, de alguma forma, na própria fronteira do discurso narrativo e do discurso citado (usualmente discurso interior) e entram muitas vezes diretamente em um ou outro discurso. Assim, podem ser interpretados como uma pergunta ou exclamação da parte do autor, mas também, ao mesmo tempo, como pergunta ou exclamação da parte da personagem, dirigida a si mesma (1929/2004, p.170).

Assim, não há como não ver o discurso direto retórico como pertencente ao estilo pictórico e não ao linear. Além disso, os autores, mais tarde, dizem que esse caso evolui para o discurso direto substituído em que há total "paralelismo de entoações" entre contexto narrativo e discurso citado. Nesse caso, portanto, estamos diante do discurso indireto livre, em que há "solidariedade total" (1929/2004, p.172) pelo autor do contexto narrativo com o autor do discurso citado. Trata-se de uma fusão da fala ou do pensamento do autor do discurso citado com o discurso do contexto narrativo. Dizem os autores que, nesse caso, as apreciações e as entoações dos dois autores são praticamente idênticas: "a narrativa é construída na tonalidade do herói, o discurso do herói na tonalidade do autor" (1929/2004, p.172).

Deste modo, enquanto ao estilo linear cabe preservar a integridade e a autenticidade das palavras do autor citado, ao estilo pictórico cabe infiltrar palavras do contexto narrativo no discurso citado e vice-versa. 
Bakhtin/Voloshinov afirmam que, quanto mais dogmática e autoritária for a palavra do outro, mais fronteiras nítidas serão erguidas sobre ela no caso de uma citação. Assim, deve-se sempre levar em conta a posição social hierárquica do indivíduo cujo discurso está sendo citado. Isso mostra que os procedimentos de transmissão da palavra do outro estão intimamente ligados à inter-relação social dos indivíduos.

Muitas dessas construções sintáticas para transmitir o discurso citado não são exclusivas da língua escrita, mas também aparecem na língua falada. Isto porque na ideologia do cotidiano ouve-se a todo instante falar do sujeito que fala e daquilo que ele fala. Na obra Questões de literatura e estética (1988), Bakhtin afirma que no cotidiano, falamos, sobretudo, daquilo que os outros dizem: "transmitem-se, evocam-se, ponderam-se, ou julgam-se as palavras dos outros, as opiniões, as declarações, as informações, indigna-se ou concorda-se com elas, discorda-se delas, refere-se a elas, etc" (1988, p.139).

Bakhtin diz que qualquer conversa é repleta de transmissões e interpretações das palavras dos outros. $\mathrm{O}$ autor chega a afirmar que de todas as palavras que pronunciamos no cotidiano metade vem da fala do outro. Isso nos faz lembrar da noção de dialogismo mais bem explicitada no capítulo 1 desta dissertação: quando falamos ou proferimos um enunciado, estamos levando em conta os enunciados produzidos anteriormente e, além disso, esperamos uma ativa compreensão responsiva por parte de nosso interlocutor. Isso porque o enunciado é um elo na cadeia da comunicação humana. Deste modo, é necessário ficarmos atentos não só às formas de representação do discurso do outro como o Círculo propõe em Marxismo, mas também aos procedimentos de transmissão deste discurso.

Em Questões de literatura e estética, Bakhtin mostra que esses procedimentos podem ser muito variados uma vez que haverá sempre um enquadramento interpretativo, uma reconsideração e uma re-acentuação que afetará diretamente o discurso citado presente no contexto narrativo. Esses fatores podem resultar, num extremo, na literalidade direta na transmissão e, no outro extremo, na deformação paródica da palavra do outro acompanhada de sua deturpação.

Contudo, o autor afirma que, ainda que se transmita o discurso do outro com precisão, ele sempre estará sujeito a notáveis transformações de significado. Isto porque "o contexto que avoluma a palavra de outrem origina um fundo dialógico cuja influência pode ser muito grande" (1988, p.141). Assim, estes dois discursos estarão sempre relacionados, ou seja, não haverá 
"imitação" da palavra do outro, haverá um desenvolvimento criativo desta palavra que está em um novo contexto e em condições novas e que, portanto, estará agora seguindo o estilo daquele que a cita. Trata-se daquela inter-relação dinâmica que o Círculo expõe em Marxismo.

Ainda em Questões, Bakhtin diz que o objeto do gênero romanesco é o homem que fala e sua palavra. Para o autor, o caráter individual, os destinos individuais e o discurso individual não são importantes para o romance. O que é importante são justamente as particularidades da palavra dos personagens que "sempre pretendem uma certa significação e uma certa difusão social: são linguagens virtuais” (1988, p.135). À diferença da epopéia que possui uma perspectiva única e exclusiva, o romance possui várias perspectivas com várias posições ideológicas diferentes. E, como as posições ideológicas só são reveladas através de palavras, a imagem da palavra do personagem é a característica principal do gênero romanesco.

Como os discursos ideológicos, com suas aspirações a uma significação social e a uma difusão, devem vir das bocas das personagens, o gênero romanesco acaba sendo uma fonte de análise para o discurso citado, uma vez que procura representar literariamente uma imagem de linguagem que contenha uma posição ideológica.

Em Problemas da poética de Dostoiévski (1963/2002), Bakhtin mostra que, nos romances deste autor, há uma variedade de tons e de estilos (as diferentes posições ideológicas dos vários personagens), mas não há um discurso-dominante nem por parte do herói nem por parte do próprio autor. Deste modo, poderíamos pensar que não há diálogo entre o contexto narrativo e as falas dos personagens. No entanto, Bakhtin nos alerta para o fato de que:

onde a narração não interfere enquanto voz do outro no diálogo interior dos heróis, onde ela não faz unidade dissonante com o discurso de um deles ela apresenta o fato sem voz, sem entonação ou como uma entonação convencional [...]. Mas esse fato sem voz e sem acento é apresentado de tal modo que pode fazer parte do campo de visão do próprio herói e tornar-se matéria para a sua própria voz, matéria para o seu julgamento de si mesmo (1963/2002, p.255).

O autor, nesse caso, não contribui nem com seu julgamento nem com sua apreciação. Esse fato, longe de ser um discurso que não apresenta inter-relação dinâmica entre o contexto narrativo e a fala dos personagens, é característico de um gênero novo: o gênero do romance polifônico, em que há várias vozes representando pontos de vista diferentes que geram um conflito. Segundo Bakhtin, 
o objeto das aspirações do autor não é, em hipótese nenhuma, esse conjunto de idéias em si mesmo, como algo neutro e idêntico a si mesmo. Não, o objeto é precisamente a passagem do tema por muitas e diferentes vozes, a polifonia de princípio e, por assim dizer, irrevogável, e a dissonância do tema. A própria distribuição das vozes e sua interação são importantes para Dostoiévski (1963/2002, p.271).

Veremos quais são os procedimentos de transmissão do discurso do outro nas reportagens de capa da Superinteressante, levando em consideração que:

1) se a palavra do outro está presente a todo momento em qualquer discurso, aqui, na prática discursiva da divulgação científica, no gênero reportagem de capa, ela é condição sine qua non ${ }^{19}$, uma vez que fala-se basicamente de alguém que já falou sobre algo, transmite-se um saber formulado anteriormente por outra pessoa;

2) ao contrário do gênero romance polifônico em que não há predominância de vozes, aqui, o contexto narrativo que vai "avolumar" o discurso citado pode dar novos significados à palavra do outro tanto pelo fato de o contexto narrativo pertencer à esfera do jornalismo que prescreve suas coerções próprias que são diferentes das da esfera da ciência, como pelo fato de esse tipo de gênero (reportagem de capa) ter em mente não só a divulgação de um saber, mas também a venda da revista;

3) se as formas de transmissão do discurso citado revelam tendências sociais, verificaremos, então, como o leitor apreende o discurso do cientista, sem deixar de levar em consideração que o contexto narrativo da revista orientará essa apreensão justamente por causa da inter-relação dinâmica e porque, segundo Bakhtin/Voloshinov, "o fim que o contexto narrativo procura alcançar é particularmente importante" (1929/2004, p.153).

Comecemos, portanto, a análise dos títulos do primeiro período para, em seguida, analisar os discursos citados.

\subsection{Análise dos títulos e imagens}

\subsubsection{Superinteressante - março de 1988}

\footnotetext{
${ }^{19}$ Não é o que acontece, por exemplo, no gênero artigo escrito pelo próprio cientista. Neste caso, ele pode não citar a palavra do outro, mas apenas falar de seu próprio trabalho.
} 
O título desta reportagem é o seguinte: "DOR. ESTE TORMENTO PODE ACABAR". Aqui, nota-se que seu tema é a cura de uma doença que já foi instalada: se o tormento pode acabar, é porque ele já se iniciou. 


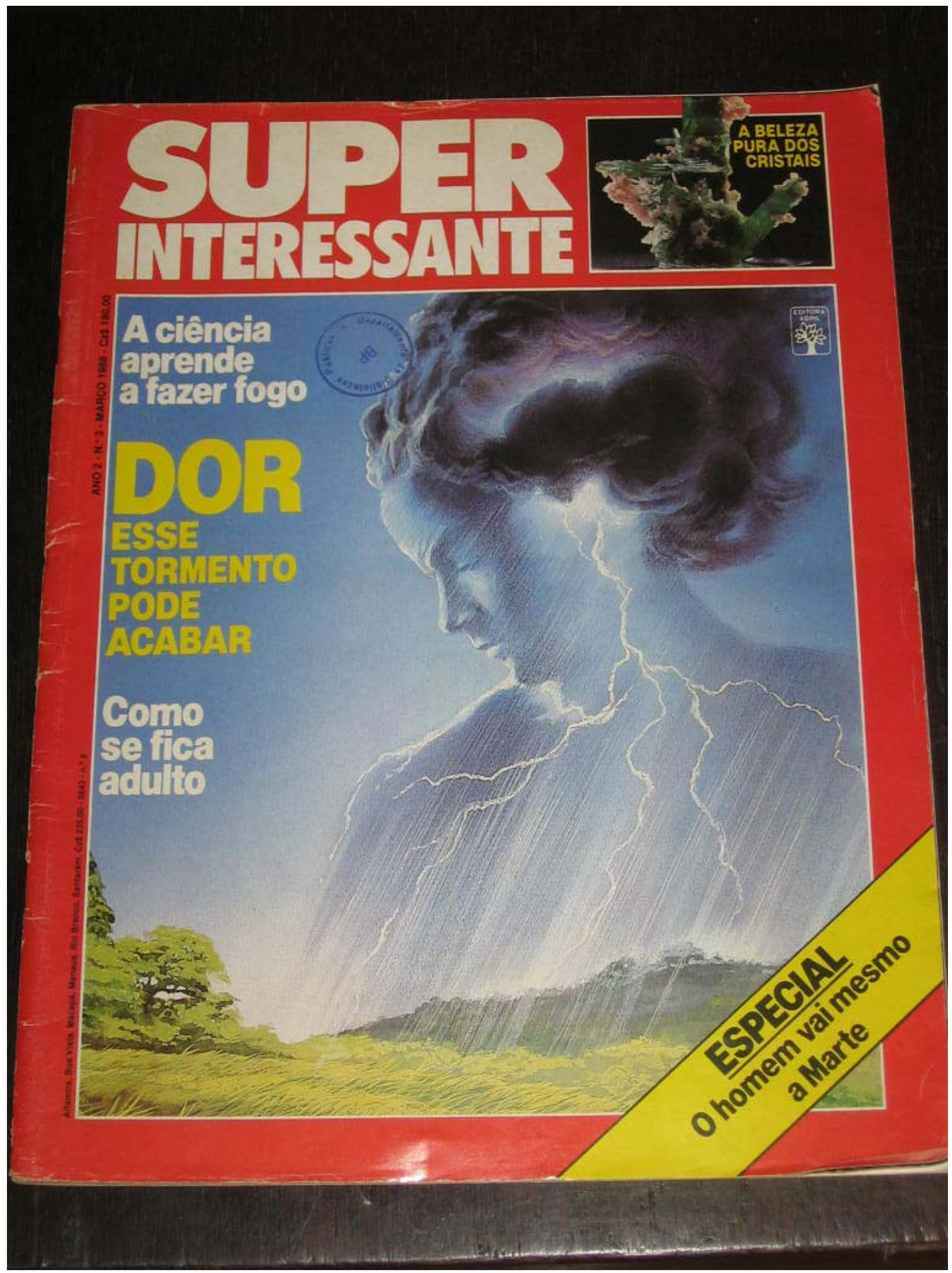


Se nos detivermos no estilo (definido por Bakhtin como a seleção dos recursos lexicais, fraseológicos e gramaticais da língua feita pelo falante), veremos que, nesta edição, a escolha do verbo acabar usado na sua forma intransitiva significa o mesmo que cessar, findar, terminar, ou seja, o tormento que já se iniciou pode cessar, findar, terminar.

A presença do modalizador pode minimiza a força da probabilidade: em uma escala formada por graus de probabilidade, o verbo poder é um dos mais fracos. Seria muito diferente dizer: "Dor. Este tormento deve acabar" ou "Dor. Este tormento vai acabar". Ao usar o modalizador pode, portanto, a voz da revista não oferece nenhuma certeza ao leitor; ela não se responsabiliza por essa afirmação até porque não há um agente explícito neste título que se manifesta como aquele que pode acabar com esse tormento. Quem pode acabar com esse tormento? Os médicos, a pessoa que sente o tormento ou a própria revista com o seu fazer o leitor saber? Não há o agente explícito na capa. Só mesmo lendo a reportagem para saber quem pode acabar com esse tormento. Neste título não há um diálogo tão explícito com o leitor. Há um fazer o leitor saber. O diálogo parece se estabelecer mais com a esfera da ciência: esta reportagem parece servir aos médicos especialistas que vão confrontar as diferentes maneiras de curar uma doença. Ao leitor leigo cabe contemplar as descobertas feitas pelas diferentes áreas da Medicina no que se refere ao combate da dor.

Usa-se um termo hiperônimo ${ }^{20}$ para generalizar o assunto. Dor pode se referir a qualquer tipo de dor: dor de cabeça, dor de ouvido, dor de estômago. Assim, generalizando o termo, generalizam-se os consumidores. Este termo é o que está em maior destaque na capa, por ter a maior fonte.

Em relação ao desenho da capa, pode-se dizer que há uma imagem negativa: nuvens pretas parecem provocar um trovão, uma tormenta. O uso desta palavra remete imediatamente ao uso de tormento do título que, por sua vez, refere-se à dor. Esta tormenta aparece personificada em um indivíduo: as nuvens pretas estão nos cabelos e os raios deste trovão vão para o corpo todo. Isto quer dizer que não é somente de dor de cabeça que a reportagem parece querer tratar, mas de dores do corpo todo. Assim, há uma intersecção de significados entre os aspectos verbais do título e os aspectos não-verbais da capa, cujo ponto em comum é a falta de controle por parte

\footnotetext{
${ }^{20}$ De acordo com Ilari \& Geraldi (1999), “a relação hiponímia é aquela que intercorre entre expressões com sentido mais específico e expressões genéricas, por exemplo, entre geladeira, liquidificador, batedeira de bolos, ferro elétrico etc. e eletrodoméstico; é a relação que intercorre entre pardal e passarinho, e que verbalizamos dizendo que 'todo pardal é passarinho, mas nem todo passarinho é um pardal”' (1999, p.52).
} 
dos indivíduos. Não podemos controlar nossas dores assim como não controlamos as tormentas da natureza. Trata-se de um fenômeno da natureza (dor) contra o qual nós não podemos lutar, a não ser os médicos/cientistas.

A cor e a fonte utilizadas destacam o título da reportagem dos outros títulos. A cor em amarelo e a fonte maior utilizada neste título conferem a esta reportagem maior importância em relação às outras que possuem o título com a cor branca e a fonte em menor tamanho. Para dar mais contraste ainda, o título situa-se no meio da capa, exatamente no meio dos dois outros títulos.

O título do interior da reportagem é composto pelo seguinte sintagma verbal: "E COMO DÓI”. Ao contrário do título da capa, de caráter mais informativo, este parece ter se valido do discurso de um leitor. Trata-se da presença de um discurso direto substituído no lugar de uma categoria (o título da reportagem) para a qual não estão previstas citações. Ao valer-se deste tipo de discurso citado no título, a reportagem aproxima-se do leitor que consegue “ouvir" seu próprio lamento na revista.

\subsubsection{Superinteressante - outubro de 1988}

Nesta edição não há igualmente um diálogo com o leitor, convidando-o explicitamente para a leitura. Há apenas uma exposição do que será falado: "MEDICINA CHINESA. CIÊNCIA DO EQUILÍBRIO”. Considerando-se que nos anos 80 a abertura à Medicina chinesa era ainda recente, a revista parece querer cumprir o papel de não só divulgar a ciência como também divulgar a ciência atual de então ${ }^{21}$. O destaque ao título é dado pelo uso da cor branca contrastando com o uso da cor amarela nos títulos das outras reportagens. Além disso, a fonte é maior e o título está situado na parte inferior da capa, bem separado dos outros dois que estão perto um do outro e na parte superior da capa.

Além disso, assim como na edição anteriormente analisada, cujo título parece querer falar de todos os tipos de dor, aqui também o título insinua que nos oferecerá um grande "Manual da Medicina Chinesa", que será capaz de nos contar tudo: quando surgiu, como funciona, quais as técnicas utilizadas etc. O título do interior da reportagem é composto da segunda parte da capa, acrescido do artigo “a”: “A CIÊNCIA DO EQUILÍBRIO”. Ao contrário do título do interior da 
${ }^{21}$ Sabemos que a Medicina chinesa é conhecida milenarmente pelos orientais, mas, aqui entre os ocidentais, ela era, na década de 80 , uma grande novidade. 


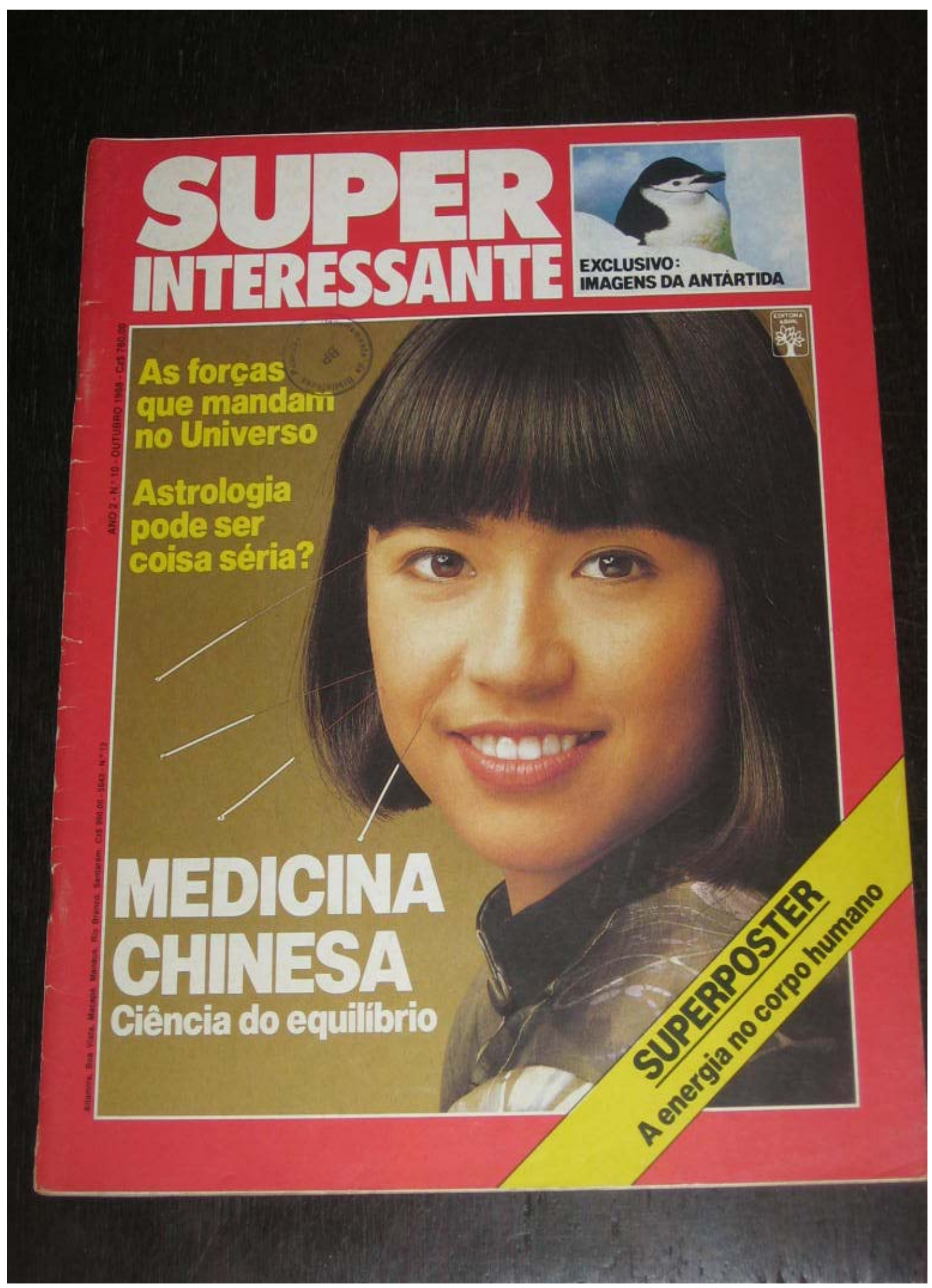


reportagem da edição anterior, esta não se aproximou do leitor, mas apenas repetiu o assunto de que se tratará.

$\mathrm{Na}$ foto da capa dessa edição, uma criança chinesa exibindo quatro agulhas espetadas em seu rosto remete a uma das mais famosas terapias desta medicina: a acupuntura. O sorriso em seu rosto parece confirmar que se trata de uma ciência de fato "equilibrada": o que seria motivo para dor e choro (agulhas espetadas), transforma-se em uma sensação positiva que inclusive resulta em um sorriso. Esse aparente paradoxo é que parece captar o leitor, já que esta Medicina promete curar alguma doença sem que se sintam dores.

\subsubsection{Superinteressante - maio de 1989}

No ano de 1989, não vemos também uma mudança no esquema lingüístico do título: “GORDOS \& MAGROS. QUEM É QUEM NA BALANÇA”. Trata-se novamente de uma exposição daquilo que será falado. Entretanto, de todas as edições do primeiro período, esta é a única que mais pareceu querer captar o leitor, ainda que de forma sutil. Em primeiro lugar, pelo texto verbal do título e, em segundo lugar, pela foto dos célebres Gordo \& Magro.

Se pensarmos que a população se divide em gordos e magros, não haveria necessidade de a revista estar se perguntando quem é quem na balança. Para o leitor, num primeiro momento, o gordo é gordo na balança, isto é, possui muitos quilos, acima do que seria o ideal; e o magro é magro, tem ou quilos a menos do que seria necessário ou está no seu peso ideal.

Assim, a dúvida que o título coloca é: será que o magro come muito, de três em três horas, como se fosse gordo e, ainda assim, continua magro? Será que o gordo come pouco, como se fosse magrinho e, ainda assim, continua gordo? Em outras palavras: existem pessoas que são gordas por fora e magras por dentro e vice-versa?

O fato de haver dois pronomes interrogativos iguais na sentença (quem), um na posição de sujeito e outro na posição de predicativo, duplica as possibilidades de leitura:

Quem é quem na balança

O gordo é magro na balança

O magro é gordo na balança.

Mas há, ainda, aquela primeira impressão do leitor leigo, cujas leituras também são válidas:

\section{O magro é magro na balança}




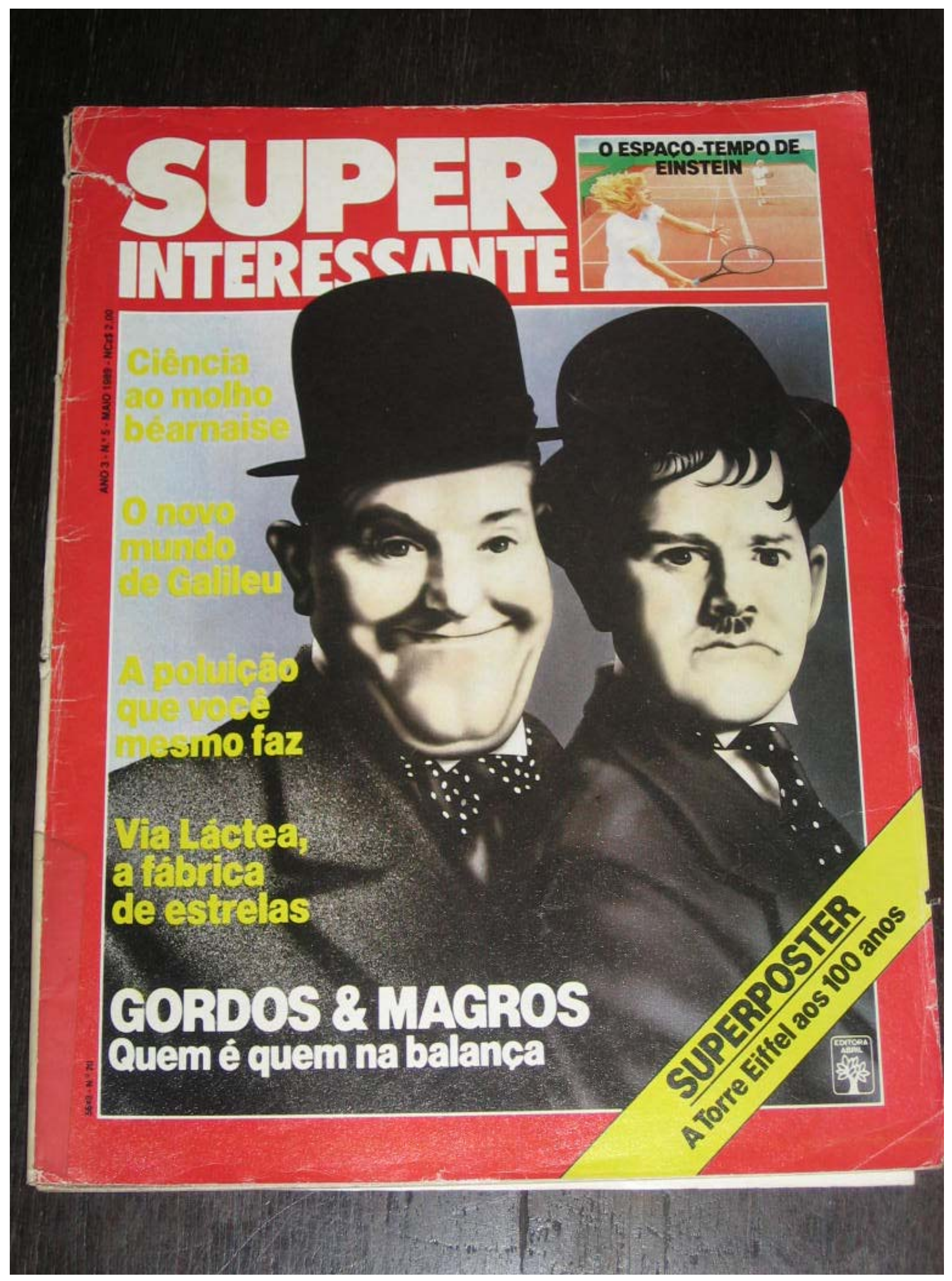


O gordo é gordo na balança.

Nós lemos, na posição de sujeito, a forma física do indivíduo e, na posição de predicativo, o modo (correto ou incorreto) como ele se alimenta.

Um outro 'encaixe' no lugar desses pronomes seria aquele em que na posição de predicativo do sujeito há o sintagma gordo ou magro e na posição do ‘quem' sujeito, encaixa-se o leitor interessado em saber a sua condição.

Deste modo, multiplicando-se as leituras, multiplicam-se também os possíveis leitores já que todos vão querer saber se, apesar da aparência, estão se alimentando corretamente. É a Super que fornecerá esta resposta fazendo o leitor saber. Há, inclusive, uma ambigüidade no título já que podemos lê-lo, pelo uso duplicado do pronome interrogativo quem, como uma pergunta ${ }^{22}$ cuja resposta virá na leitura da reportagem ${ }^{23}$ :

Gordo \& Magros. Quem é quem na balança (?).

Neste caso, o leitor, curioso em saber sua condição, identifica-se com a "pergunta" da revista e pressupõe que terá a resposta no interior da reportagem.

Uma outra interpretação seria aquela em que não se lê esse possível ponto de interrogação, que de fato não há, mas somente algo como:

Gordos \& Magros. (A Super vai mostrar) quem é quem na balança.

Aqui, reforça-se a imagem de que a Super é detentora de um saber que o leitor não possui, enquanto na outra leitura, a Super compartilha uma dúvida com o leitor e, por meio dela, aproxima-se dele.

Talvez não tenha havido esta dupla intenção por parte da voz da Super. Todavia, não há como nos esquecermos dos ensinamentos de Bakhtin para quem há sempre um conjunto de decisões nos procedimentos lingüísticos. Além disso, uma vez proferido, um enunciado deve ser respondido pelo leitor/ouvinte, primeiramente, no modo de interpretar e, em seguida, no modo de agir:

[...] o ouvinte, ao perceber e compreender o significado (lingüístico) do discurso, ocupa simultaneamente em relação a ele uma ativa posição responsiva: concorda ou discorda dele (total ou parcialmente), completa-o, aplica-o, prepara-se para usá-lo, etc.; essa posição responsiva do ouvinte se forma ao longo de todo o processo de audição e compreensão desde seu início, às vezes literalmente a partir da primeira palavra do falante. Toda compreensão da fala viva, do enunciado vivo é de natureza ativamente

\footnotetext{
${ }^{22}$ Os títulos de reportagens em forma de pergunta são freqüentes no $3^{\circ} \mathrm{e}$ último período, em que há um diálogo explícito com o leitor.

${ }^{23} \mathrm{E}$, anteriormente, na compra da revista.
} 
responsiva (embora o grau desse ativismo seja bastante diverso); toda compreensão é prenhe de resposta, e nessa ou naquela forma a gera obrigatoriamente: o ouvinte se torna falante. A compreensão passiva do significado do discurso ouvido é apenas um momento abstrato da compreensão ativamente responsiva real e plena, que se atualiza na subseqüente resposta em voz alta real (2003, p.271).

Além do texto verbal, o texto não-verbal, parte da forma composicional do gênero reportagem de capa, é a foto dos personagens Gordo \& Magro. Trata-se de uma das duplas de comediantes mais famosa do século XX, mas que durante a Segunda Guerra Mundial já havia encerrado sua carreira. Em maio de 1989, data desta edição, a dupla havia encerrado sua carreira há mais de 4 décadas. No entanto, devido ao sucesso desses comediantes, a revista se utilizou de sua imagem para tratar desse tema ${ }^{24}$. Há, portanto, um explícito conhecimento do outro para quem o enunciado da capa está sendo endereçado, ou seja, a voz da revista se vale dos conhecimentos que o leitor possui não só da ciência como também de outras esferas da atividade humana e isso determina as escolhas verbais e não-verbais para compor a capa. Nas palavras de Bakhtin,

Ao falar, sempre levo em conta o fundo aperceptível da percepção do meu discurso pelo destinatário: até que ponto ele está a par da situação, dispõe de conhecimentos especiais de um dado campo cultural da comunicação; levo em conta as suas concepções e convicções, os seus preconceitos (do meu ponto de vista), as suas simpatias e antipatias - tudo isso irá determinar a ativa compreensão responsiva do meu enunciado por ele. Essa consideração irá determinar também a escolha do gênero do enunciado e as escolha dos procedimentos composicionais e, por último, dos meios lingüísticos, isto é, o estilo do enunciado (2003, p.302)

Levar em conta os conhecimentos presumidos do leitor é próprio da DC, cuja característica é se valer de discursos de outras atividades. No caso, além de coordenar os discursos da ciência e do cotidiano, há a presença do discurso artístico que torna a capa mais atraente, mais próxima dos domínios do leitor. O leitor, provável conhecedor da dupla, certamente se lembrará que, embora fosse o mais criativo, o Magro era sempre o que interpretava o perdedor. Daí a cara séria na foto da capa, opondo-se ao sorriso do Gordo. Essas duas expressões faciais contribuem para uma das possíveis leituras do texto verbal, que provém do senso comum: o magro é sério porque come pouco e o gordo é feliz porque sabe desfrutar bem dos prazeres que muitos tipos de comida proporcionam.

\footnotetext{
${ }^{24}$ Até por que, eles eram conhecidos como Gordo \& Magro aqui no Brasil; nos Estados Unidos, a dupla era conhecida Laurel e Hardy, sobrenome dos comediantes.
} 
O título vem em destaque não só pela maior fonte utilizada como também pelo uso da cor branca em contraste com os outros títulos menores que aparecem com a cor amarela. Assim como na edição anterior, o título se situa na parte inferior da capa.

No interior da reportagem, temos o sintagma nominal "A BATALHA DA BALANÇA", situado na parte superior da primeira página da reportagem. O uso da palavra 'batalha', nesse contexto, refere-se ao indivíduo gordo que luta para ter quilos a menos e ao indivíduo magro que luta para ter quilos a mais. Não há, na verdade, dois combatentes nesta batalha, mas sim um indivíduo lutando não contra alguém, mas por um objetivo. Cabe somente uma única pessoa na arena (a balança) dessa batalha.

\subsubsection{Superinteressante - novembro de 1989}

A edição de novembro de 1989 quebra aquilo que pareceu ser uma mudança na edição anteriormente analisada. Não há nada que pareça promover um diálogo com o leitor neste título: “SANGUE. UM MERGULHO NESTE PRECIOSO LÍQUIDO”. Expõe-se o assunto e se faz um comentário sobre ele, com a utilização do adjetivo precioso que seria pouco provável no discurso científico. Dentre os significados de precioso temos “de alto preço ou grande valor", isto é, ao utilizar este adjetivo para qualificar sangue, há, conseqüentemente, uma valorização da própria reportagem que, por estar tratando de algo de alto preço ou grande valor, é ela também muito

valorizada. A palavra mergulho remete não só à palavra líquido, semanticamente relacionadas já que só mergulhamos algo no estado líquido de alguma substância, como também e principalmente à própria reportagem que, metaforicamente, vai mergulhar no assunto e não "nadar superficialmente" por ele. Assim, a revista mostra que ela não vai tratar do assunto parcialmente, mas vai entregar-se totalmente/inteiramente a esta atividade que é falar sobre o sangue. Há, portanto, uma valorização da imagem da revista que procura esgotar um assunto. Por outro lado, não se vê um diálogo explícito com o leitor, há uma exposição daquilo que será falado. Igualmente no título usado no interior da reportagem que retoma parte do título da capa: PRECIOSO LÍQUIDO. Não há aqui qualquer índice de diálogo com o leitor.

A foto da capa tampouco é convidativa à leitura: temos um corte feito em um dos dedos de uma pessoa por um espinho cujo efeito foi o aparecimento de sangue. Essa pequenina poça de sangue no dedo que aparece na capa é, sem dúvida, menos chamativa do que uma capa que mostrasse alguém sangrando muito em várias regiões do corpo. Entretanto, essa pequena 


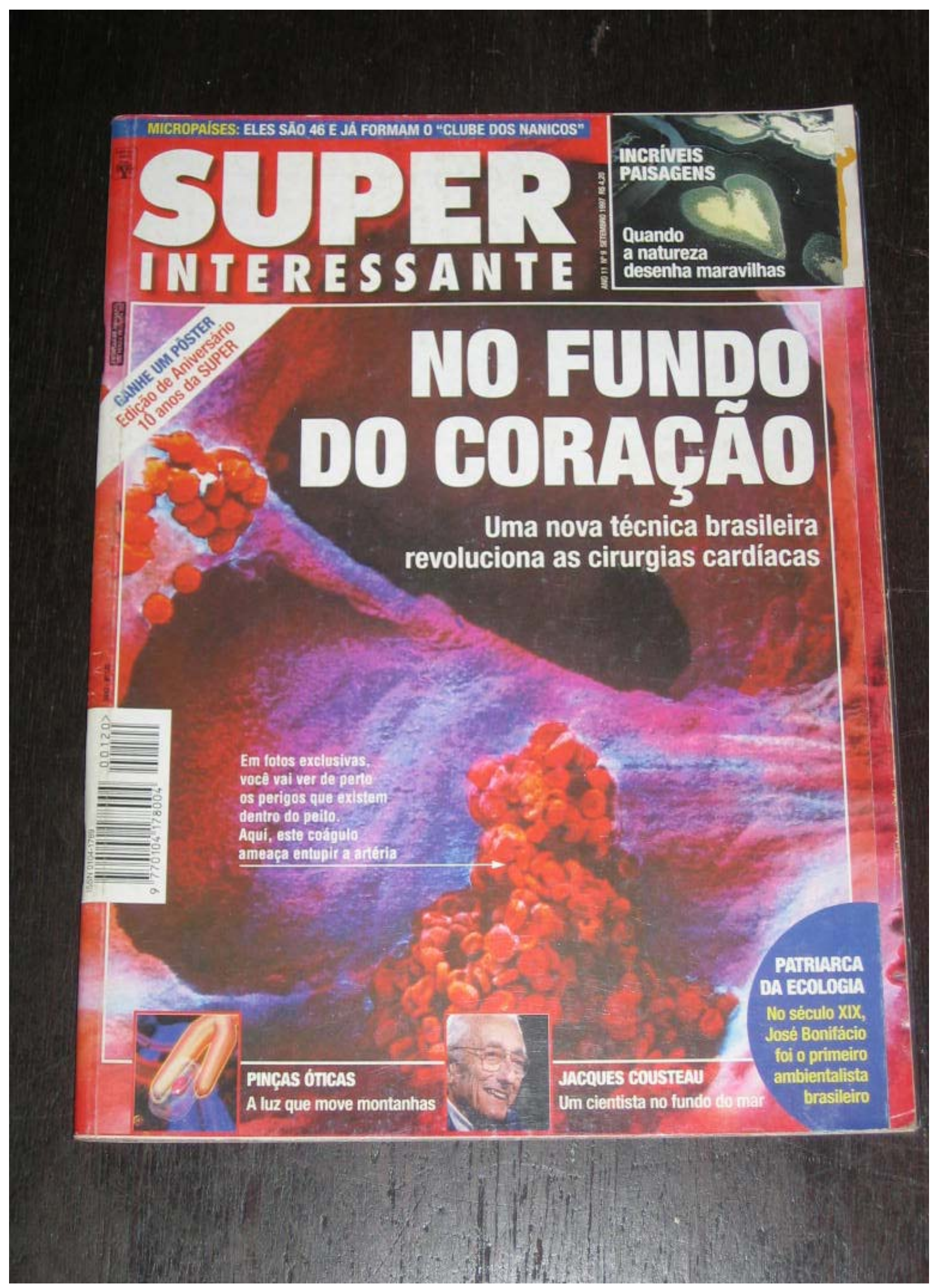


quantidade de sangue na capa remete à pequena amostragem de sangue que tiramos do dedo para fazer alguns testes como, por exemplo, de glicemia, de anemia ou, ainda, para sabermos o nosso tipo de sangue. A foto, portanto, remete a esse procedimento clínico de avaliação e análise por que passa uma gota de sangue. Assim, evita-se a capa com muitos litros de sangue e remete-se, com uma só gota, a procedimentos científicos de cujo discurso a DC se utiliza. Se com apenas uma gota, é possível obter várias informações sobre o sangue, com uma reportagem, também é possível fazê-lo.

Igualmente às duas edições anteriormente analisadas, o título aparece na parte inferior da capa. A cor utilizada é a amarela em contraste com a cor branca usada nos outros títulos.

\subsubsection{Síntese dos títulos e imagens do primeiro período:}

Concluindo, pode-se dizer que os títulos e as imagens analisados neste primeiro período mantêm alguns traços em comum tais como:

1) o uso de termos hiperônimos que generalizam o assunto e, logo, prometem uma síntese geral: o termo dor não especificado na primeira edição analisada pode englobar todos os tipos de dores: dor de cabeça, dor de dente etc ${ }^{25}$. O uso de Medicina chinesa também provoca a impressão de que se falará de tudo a respeito dela - tarefa difícil para uma revista mensal cujas reportagens de capa não ultrapassam 30 páginas. Na terceira edição analisada, os vários encaixes possíveis no lugar dos dois quem, parecem dar conta de todos os tipos humanos. Na última edição, não há termos hiperônimos, mas a palavra mergulho causa também o efeito de sentido de que se dissertará tudo sobre o sangue.

2) a suposta falta de captação do leitor. Conforme se viu, não há marcas explícitas de diálogo, como o uso do pronome você ou o uso de imperativos convidando ou sugerindo que o leitor compre a revista. Entretanto, ao usar termos tão gerais, caso da primeira edição analisada que fala da possibilidade de acabar com a dor, generalizam-se também os vários consumidores, afinal, quase todo mundo tem algum tipo de dor, logo, quase todo mundo pode (ou deve?) comprar a revista. A edição de outubro de 1988 que parece prometer uma cura sem dor, como vemos na foto da capa, também parece captar o leitor. Do mesmo modo, a edição de maio de 1989, em que há

\footnotetext{
${ }^{25}$ Parafraseando o exemplo de Ilari \& Geraldi (1999), teríamos algo como "toda dor de dente é uma dor, mas nem toda dor é uma dor de dente".
} 
uma captação um pouco maior do leitor que quer saber de sua condição física e se está se alimentando corretamente. Além disso, a foto de personagens famosos, chamando a atenção não só de um curioso em ciências, como de um apaixonado por cinema. A última edição é aquela que menos favorece a captação do leitor, nem todos estão interessados em saber como o sangue funciona. Certamente, há mais pessoas interessadas em acabar com algum tipo de dor que sente ou em deixar de ser gordo etc.;

3) em todos os títulos deste período, encontramos a mesma organização lingüística, sugerindo ser este o estilo dos títulos da Super neste primeiro período:

Dor. Este tormento pode acabar.

Medicina chinesa. Ciência do equilíbrio.

Gordos \& Magros. Quem é quem na balança.

Sangue. Um mergulho neste precioso líquido.

Há, em todos eles, a presença de elementos dados (dor, medicina chinesa, gordos e magros, sangue) e elementos novos, isto é, aquilo que se falará na reportagem sobre eles. Segundo Koch, "é com base na informação dada, responsável pela locação do que vai ser dito no espaço cognitivo do interlocutor, que se introduz a informação nova, que tem por função introduzir nele novas predicações a respeito de determinados referentes, com o objetivo de ampliar e/ou reformular os conhecimentos já estocados a respeito deles” (1998, p.31). Nota-se a coesão textual por meio das retomadas pronominais e anafóricas: este tormento $=$ dor; quem/quem = gordo/magro; neste precioso líquido = sangue; e por meio de construção em que se justapõem dois blocos de informação, sem ligação sintática, mas com ligação semântica: medicina chinesa $=$ ciência do equilíbrio. Todos os elementos dados são os que aparecem na fonte maior em todos esses títulos. Os elementos novos aparecem em uma fonte menor, embora ela ainda seja maior em relação aos outros títulos presentes nas capas. A revista sabe que o leitor já tem, da ideologia do cotidiano, conhecimento dos elementos dados e o que ela faz é construir uma ponte com a esfera da ciência. Essa ponte, no entanto, é construída com os materiais, isto é, com os recursos verbais e não verbais, da esfera do jornalismo o que causa uma refração do tema. Isto quer dizer que vamos analisar a dor sob o prisma do jornalismo que divulga ciência e não sob o prisma de um poeta que faz da dor um belo poema. Ao usar uma fonte maior nos elementos dados, portanto, a revista capta mais facilmente o leitor, pois ele, à primeira vista, "conhece" o assunto. 
Vejamos agora, nas reportagens, por meio do discurso citado, como se discorre sobre a dor, a medicina chinesa, os gordos e magros, e o sangue. Em outras palavras: veremos como o jornalista vai gerenciar as vozes que falam sobre esses assuntos, isto é, como elas estão distribuídas e também como essas vozes aparecem de acordo com a tipologia de Bakhtin/Voloshinov.

\subsection{Análise dos discursos citados}

\subsubsection{Superinteressante - março de 1988}

Antes de passar para a análise dos discursos citados, é preciso dizer que esta reportagem possui 6 páginas, 6 fotos, 2 desenhos, 3 boxes ("Emoções doloridas", "O circuito da dor”, "Armas do alívio"). Somam-se a isso os 23 parágrafos onde aparecem as vozes que compõem a reportagem. Esses parágrafos se dividem em 4 blocos: o primeiro é uma introdução à reportagem (par. 1-3) e os outros 3 vêm com sub-títulos que antecipam aquilo de que se tratará: "A princípio, sentir dor pode ser um bom sinal" (par.4-8); "O melhor dos analgésicos é produzido pelo cérebro" (par.9-18); "Na vida do brasileiro, há sempre uma dor de cabeça" (par.19-23). Todas essas divisões no texto referem-se à forma composicional do gênero reportagem de capa. Uma vez que a voz da revista sabe que o leitor quer estar bem informado, mas não quer gastar o tempo de uma pesquisa científica na aquisição desta informação, a reportagem se fragmenta em várias partes, tornando a leitura fácil, agradável e rápida. Isso quer dizer que a revista tem conhecimento do outro a quem a reportagem está sendo endereçada. Se assim não fosse, a reportagem ficaria mais aos moldes de gêneros da esfera da ciência. Além disso, os conhecimentos prévios que o leitor tem do tema em questão também devem influenciar no estilo da reportagem que vai se utilizar, como veremos a seguir, de conhecimentos da ideologia do cotidiano para, em seguida, ancorar conhecimentos e explicações da esfera da ciência.

O discurso citado é outra característica fundamental da forma composicional da reportagem; no caso da DC, os discursos citados devem se distribuir de forma que o leitor tenha credibilidade nas informações veiculadas pela revista. Isto vai acontecer privilegiadamente nas falas de cientistas, especialistas e médicos.

Vejamos agora os tipos de discurso citado que aparecem nesta reportagem:

\begin{tabular}{|l|l|}
\hline Tipo de discurso & Reprodução \\
\hline Discurso Direto & 1) Para medir uma dor, os médicos só contam com um instrumento: o relato de quem a sente. \\
\hline
\end{tabular}




\begin{tabular}{|c|c|}
\hline Preparado & $\begin{array}{l}\text { "Nossa filosofia é sempre acreditar no paciente", diz o neurologista Jorge Roberto Pagura, } 39 \\
\text { anos, da Escola Paulista de Medicina (par.15). } \\
\text { 2) Há oito anos, ele fundou em São Paulo a primeira clínica particular do Brasil para } \\
\text { tratamento da dor - não aquela que serve como alarme, mas as dores crônicas. "Elas não são } \\
\text { um aviso. Elas são o próprio problema", diz (par.15). } \\
\text { 3) Quase sempre, segundo o neurologista, o diagnóstico é encontrado. "A dor tem uma razão } \\
\text { fisiológica que deve ser tratada", explica Pagura. "Muitas vezes, localizada a causa da dor, o } \\
\text { paciente é encaminhado a especialistas e fisioterapeutas - exercícios específicos e medicação } \\
\text { resolvem mais de } 70 \text { por cento dos casos" (par.16). } \\
\text { 4) Foi trabalhando num desses ambulatórios, o do Hospital dos Servidores Públicos de São } \\
\text { Paulo, que o neurologista Célio Levymann acabou se especializando em dor de cabeça. "A } \\
\text { cura de dores crônicas como a enxaqueca é fácill, desde que o diagnóstico seja adequado", diz } \\
\text { ele (par.18). } \\
\text { 5) O doutor Jou, porém, não discrimina as explicações da ciência ocidental para o fenômeno. } \\
\text { "Embora a questão da energia seja fundamental para a tradição chinesa", diz, "estudos } \\
\text { avançados provaram que as agulhas, na verdade, estimulam a produção das endorfinas, além } \\
\text { de bloquear a chegada dos sinais da dor" (par. 21). } \\
\text { 6) Outros médicos, porém, afirmam que nem sempre esse tratamento oferece resultados } \\
\text { positivos. "De fato", esclarece o doutor Jou, "as agulhas eliminam cólicas renais ou } \\
\text { menstruais. Mas, se a pessoa está com a energia muito baixa, precisamos elevar esse nível, } \\
\text { antes de tratar de outras dores mais complexas" (par.22). }\end{array}$ \\
\hline $\begin{array}{l}\text { Discurso Indireto } \\
\text { Analisador do } \\
\text { Conteúdo } \\
\text { (com verbos de } \\
\text { elocução) }\end{array}$ & $\begin{array}{l}\text { 1) Os cientistas acham que qualquer estrutura sensitiva pode desencadear a dor e não apenas } \\
\text { os nociceptores especializados (par.13). } \\
\text { 2) Os cientistas, porém, estão quase certos de que, em excesso, analgésicos eventualmente se } \\
\text { viram contra o feiticeiro e, em vez de fazerem a dor sumir num piscar de olhos, como num } \\
\text { passe de mágica, podem aumentá-la (par.19). } \\
\text { 3) O doutor Jou assegura que as agulhas eliminam qualquer dor em duas ou três sessões (par. } \\
\text { 22). } \\
\text { 4) Outros médicos, porém, afirmam que nem sempre esse tratamento oferece resultados } \\
\text { positivos (par. 22). } \\
\text { 5) Por exemplo, injeções de morfina no cérebro ou a coagulação de uma pequena área da } \\
\text { medula espinhal, Mazar insiste em que mesmo pacientes desenganados podem ser poupados } \\
\text { do sofrimento (par.23). }\end{array}$ \\
\hline $\begin{array}{l}\text { Discurso Indireto } \\
\text { Analisador do } \\
\text { Conteúdo } \\
\text { (com } \\
\text { modalizadores) }\end{array}$ & $\begin{array}{l}\text { 1) Os brasileiros, segundo os pesquisadores, estariam entre os mais resistentes (par. 12). } \\
\text { 2) Para a ciência - embora isso agrida a experiência concreta de cada um - não há dores } \\
\text { menos ou mais dolorosas (par. 13). } \\
\text { 3) Segundo uma teoria, a percepção seria também efeito da "memória de dor" - um conjunto } \\
\text { de conceitos, lembranças e associações (par. 14). } \\
\text { 4) Quase sempre, segundo o neurologista, o diagnóstico é encontrado (par. 16). } \\
\text { 5) Para o acupunturista Jou Eel Jia, de São Paulo, a dor - como prega a medicina chinesa - é } \\
\text { causada quando a energia que deve fluir por todo o corpo fica estagnada ou não passa por um } \\
\text { determinado ponto (par.21) } \\
\text { 6) Para ele, em suma, deve-se viver e morrer sem dor (par.23). }\end{array}$ \\
\hline $\begin{array}{c}\text { Discurso Indireto } \\
\text { Analisador } \\
\text { da expressão }\end{array}$ & $\begin{array}{l}\text { 1) Alguns podem suportar uma dor durante um certo tempo, mas decididamente ninguém } \\
\text { suporta quem reclama de dor muito tempo. "Como vai?" - alguém lhe pergunta, e o maria-das } \\
\text { dores, em vez de um cortante "tudo mal", explica que arde, aperta, pinica, perfura, belisca, } \\
\text { queima, irrita, estremece, lateja aqui e ali. (par.1). } \\
\text { 2) Sofrer, como escreveu o poeta francês Charles Baudelaire (1821-1867), "é um divino } \\
\text { remédio para as nossas impurezas" (par.3). } \\
\text { 3) Apenas em 1957, uma encíclica de Pio XII autorizou os médicos católicos a usar morfina } \\
\text { "em doses moderadas" para acalmar o suplício dos pacientes (par.3). } \\
\text { 4) Pois foi o filósofo francês René Descartes (1596-1650), o mesmo que afirmou "penso, logo } \\
\text { existo", quem primeiro desenhou um possível caminho da dor, que seria uma ligação direta da } \\
\text { área dolorida até o cérebro (par.8). } \\
\text { 5) O povo parece ter aprendido isso antes dos cientistas: quem, sentindo dor, já não ouviu o } \\
\text { conselho: "Pense em outra coisa, que passa?" (par.10) }\end{array}$ \\
\hline
\end{tabular}


6) Portanto, o ditado deveria ser "mulher que é mulher não chora", pois os homens nesse aspecto são o sexo mais frágil" (par.12).

Antes de passarmos à análise dos discursos citados, é necessária mais uma tabela que mostra como as vozes das diferentes esferas da atividade humana estão distribuídas nesta reportagem:

\begin{tabular}{|l|l|l|l|l|}
\hline Voz da Ciência & Voz da ideologia do cotidiano & Voz da Arte & Voz da Filosofia & Voz da Religião \\
\hline $\begin{array}{l}17 \text { discursos } \\
\text { citados }\end{array}$ & 3 discursos citados & $\begin{array}{l}\text { 1 discurso } \\
\text { citado }\end{array}$ & $\begin{array}{l}1 \text { discurso } \\
\text { citado }\end{array}$ & $\begin{array}{l}1 \text { discurso } \\
\text { citado }\end{array}$ \\
\hline
\end{tabular}

Como se vê, por se tratar de divulgação científica, a voz jornalística da revista dá prioridade e destaque à voz da ciência. De um total de 23 discursos citados, 17 são atribuídos a cientistas, ora eles apresentados pelo nome/instituição de origem/especialidade, ora eles entendidos de uma forma generalizada ("os cientistas", "outros médicos").

O contexto narrativo, portanto, não expõe somente a visão da ciência sobre a dor, mas também a de outros campos, como a Arte, representada por Baudelaire; a Religião, representada pela encíclica de PioXII; a Filosofia, representada por Descartes ${ }^{26}$; e a ideologia do cotidiano, representada pela voz do povo, por provérbios e conselhos.

No caso do discurso em que aparece a ideologia do cotidiano, a falta de nomes tende a generalizar o comportamento presente nesta citação. Provavelmente, tanto o jornalista quanto o leitor passaram pela mesma situação:

Alguns podem suportar uma dor durante um certo tempo, mas decididamente ninguém suporta quem reclama de dor muito tempo. "Como vai?" - alguém lhe pergunta, e o maria-das dores, em vez de um cortante "tudo mal", explica que arde, aperta, pinica, perfura, belisca, queima, irrita, estremece, lateja aqui e ali. (par.1).

Entretanto, além de aparecerem em quantidade muito menor, a forma utilizada para transmitir as vozes dessas outras esferas foi o discurso indireto analisador da expressão em que as palavras, embora na mesma estrutura sintática do contexto narrativo, são colocadas entre aspas, para não se misturarem semanticamente com o contexto narrativo. Isso cria uma distância entre a voz do contexto narrativo e as vozes das outras esferas. Todavia, não há como não ver nessas outras vozes "mais conhecidas" uma função de captação do leitor, por meio do diálogo com conhecimentos presumidos, para a continuação da reportagem que apresentará explicações científicas nunca antes ouvidas e sem qualquer recurso melódico para facilitar a memorização 
como é o caso dos provérbios. Essas vozes conhecidas, mais próximas do discurso do leitor, tornam a leitura da reportagem (e, principalmente, as passagens que contêm explicações científicas) mais fácil, além de contribuírem para o entendimento:

Por exemplo, descobriu-se que, quando se está concentrado numa atividade qualquer e não na dor em si, a produção de endorfinas aumenta. O povo parece ter aprendido isso antes dos cientistas: quem, sentindo dor, já não ouviu o conselho: "Pense em outra coisa, que passa?" (par.10).

Neste exemplo, há uma clara passagem do discurso da ciência para o discurso da ideologia do cotidiano. Assim, o leitor rapidamente associa a explicação a um fato comum da vida cotidiano e internaliza o discurso da ciência. A voz da revista foi capaz de concentrar em um mesmo parágrafo discursos outrora distantes.

Temos 6 casos de discurso direto preparado, mas, agora, trata-se da voz da ciência. $\mathrm{O}$ contexto narrativo procura se distanciar da voz da ciência apesar de antecipar os temas que virão nas falas dos cientistas que, nos seus turnos, terão suas próprias entoações. Comprova-se tal antecipação pela presença de anáforas (como no exemplo a seguir) que retomam algo que já fora falado antes no contexto narrativo:

Há oito anos, ele fundou em São Paulo a primeira clínica particular do Brasil para tratamento da dor - não aquela que serve como alarme, mas as dores crônicas. "Elas não são um aviso. Elas são o próprio problema", diz (par.15), grifos meus.

O uso desse tipo de discurso citado gera o efeito de sentido da credibilidade da informação que está sendo veiculada para o leitor: não é a voz do jornalismo, mas a voz da ciência que está falando. Entretanto, no contexto narrativo, as vozes estão misturadas. Quem é que fala: "não aquela que serve como alarme, mas as dores crônicas"?. Essa fala pode ser perfeitamente atribuída tanto ao jornalista quanto ao especialista.

Para dar mais credibilidade ainda, os médicos especialistas, a quem estes discursos são atribuídos, são primeiro apresentados (nome/instituição de origem/especialidade) para depois suas falas aparecerem:

Foi trabalhando num desses ambulatórios, o do Hospital dos Servidores Públicos de São Paulo, que o neurologista Célio Levymam acabou se especializando em dor de cabeça. "A cura de dores crônicas como a enxaqueca é fácil, desde que o diagnóstico seja adequado", diz ele.(par.18).

Nas transmissões que se valem do discurso direto preparado, há, ainda a presença do verbo dizer ( 2 vezes) uma presença do verbo explicar e uma do verbo esclarecer. O verbo explicar, diferentemente de dizer que não carrega nenhuma avaliação ou condicionamento de

\footnotetext{
${ }^{26}$ Esta célebre frase de Descartes, no entanto, de tão repetida, parece quase se enquadrar como um provérbio do que como filosofia.
} 
interpretação, possui em sua semântica o fato de que aquele que explica sabe mais do que aquele a quem está sendo endereçado o discurso. Tem-se, assim, a ciência, personificada na voz de um especialista, como detentora de um saber que o leitor não tem. O mesmo ocorre com o verbo esclarecer. Quem esclarece é quem tem o poder de tornar claro e compreensível algum assunto. No caso, o cientista Jou.

Há, ainda, 11 casos de discurso indireto analisador do conteúdo, sendo 5 com verbos de elocução e 6 com modalizadores. A característica desta variante é preservar a integridade e a autonomia da voz do outro em termos semânticos. Ao usar verbos de elocução, a voz da revista avalia e condiciona a recepção dessas falas por parte do leitor. Temos acham e estão quase certos quando se transmite a voz dos cientistas em geral. Esses verbos dão o efeito de sentido da incerteza, da dúvida. Entretanto, quando há um único autor atribuído ao discurso, aparecem, por exemplo, assegura e insiste, verbos que denotam mais segurança e certeza. Há, ainda, a presença do verbo de elocução afirmam que introduz um discurso citado atribuído a outros médicos que, embora pareça um tanto quanto generalizado, não é igual a cientistas que podem ser especialistas em várias áreas, não só em medicina. Além disso, pela reportagem podemos crer na consulta a outros médicos, não só os orientais, para saber suas opiniões a respeito da acupuntura. Todos esses efeitos de sentido provêm dos verbos de elocução utilizados no discurso indireto cuja "alma", como diz Bakhtin/Volshinov, é a análise da voz do outro.

O discurso indireto analisador do conteúdo com modalizadores foi a forma utilizada quando se transmitiu um discurso cujo autor é uma perspectiva, uma entidade: segundo uma teoria, para a ciência. Com isso, consegue-se também o efeito de sentido da distância e da preservação do discurso citado.

Podemos concluir que a voz da revista enfatiza a voz do campo da ciência para tratar da dor, tanto pelo alto número de citações quanto pelos procedimentos de transmissão de suas falas. Um outro aspecto a ser destacado é quantidade e a variedade de especialistas consultados. As vozes das outras esferas (religião, arte, filosofia e ideologia do cotidiano), tanto pelo baixo número de citações quanto pelo procedimento usado para serem transmitidas, foram colocadas na reportagem de maneira a orientar o leitor na opção pela voz da ciência como a forma mais inteligente de explicar e solucionar o fenômeno da dor. Ao se utilizar o discurso indireto analisador da expressão para transmitir essas vozes, a revista dá a entender que essas esferas não têm o conhecimento necessário para falar de ciência. A expressividade das vozes dessas outras 
esferas são claramente percebidas como estranhas ao discurso da ciência, podendo, portanto, ser dispensadas do conhecimento que o leitor quer adquirir. Bakhtin/Volshinov afirmam, a respeito do uso de discurso indireto analisador da expressão:

As palavras e expressões de outrem integrados no discurso indireto e percebidos na sua
especificidade (particularmente quando são postos entre aspas), sofrem um
"estranhamento", para usar a linguagem dos formalistas, um estranhamento que se dá
justamente na direção que convém às necessidades do autor: elas adquirem relevo, sua
"coloração" se destaca mais claramente, mas ao mesmo tempo elas se acomodam aos
matizes da atitude do autor - sua ironia, humor, etc (1929/2004, p.163).

Portanto, a função das vozes dessas outras esferas não foi dar alguma explicação sobre o fenômeno da dor, mas apenas tornar mais fácil o caminho até o discurso da ciência para o qual, nesta reportagem, essas vozes são "estranhas".

\subsubsection{Superinteressante - outubro de 1988}

Vejamos agora a segunda edição do primeiro período.

Esta reportagem fala sobre as técnicas de uma medicina milenarmente conhecida no Oriente, a medicina chinesa. $\mathrm{Na}$ época da publicação desta reportagem (final da década de 80), esta medicina estava se introduzindo no Ocidente. A Superinteressante, inserida na esfera do jornalismo que prioriza atualidades, destaca a "novidade" e produz esta reportagem que é composta de 9 páginas, 9 fotos, 1 grande pôster que ocupa 3 páginas e mostra quais são os pontos de acupuntura em nosso corpo, 1 boxe explicativo ("Energia no computador”). São 19 parágrafos divididos em uma introdução (par.1-2) e 4 outros blocos de parágrafos que vêm encimados por sub-títulos que resumem aquilo de que se falará: "O organismo é entendido de uma forma diferente" (par.3-8); “Os chás são o remédio mais procurado" (par.9-12); "Qigong: técnica milenar de curar com as mãos" (par.13-16); "A busca de explicações em conceitos ocidentais" (par.17-19). Novamente aqui, esta quantidade de fragmentações está intimamente relacionada ao gênero reportagem de capa de divulgação científica. As articulações composicionais de um gênero levam em conta o diálogo com o leitor, isto é, o conhecimento que a revista tem de seu leitor-alvo. Como sabe que este quer se aprofundar em um tema, porém, sem gastar o mesmo tempo que é gasto em uma pesquisa científica, a reportagem deve ser grande, mas fragmentada para que o leitor não se canse e, ao mesmo tempo, sinta-se bem informado pelo assunto.

Os discursos citados que aparecem nesta reportagem estão reproduzidos na tabela a seguir: 


\begin{tabular}{|c|c|}
\hline Tipo de discurso & Reprodução \\
\hline $\begin{array}{l}\text { Discurso Direto } \\
\text { Preparado }\end{array}$ & 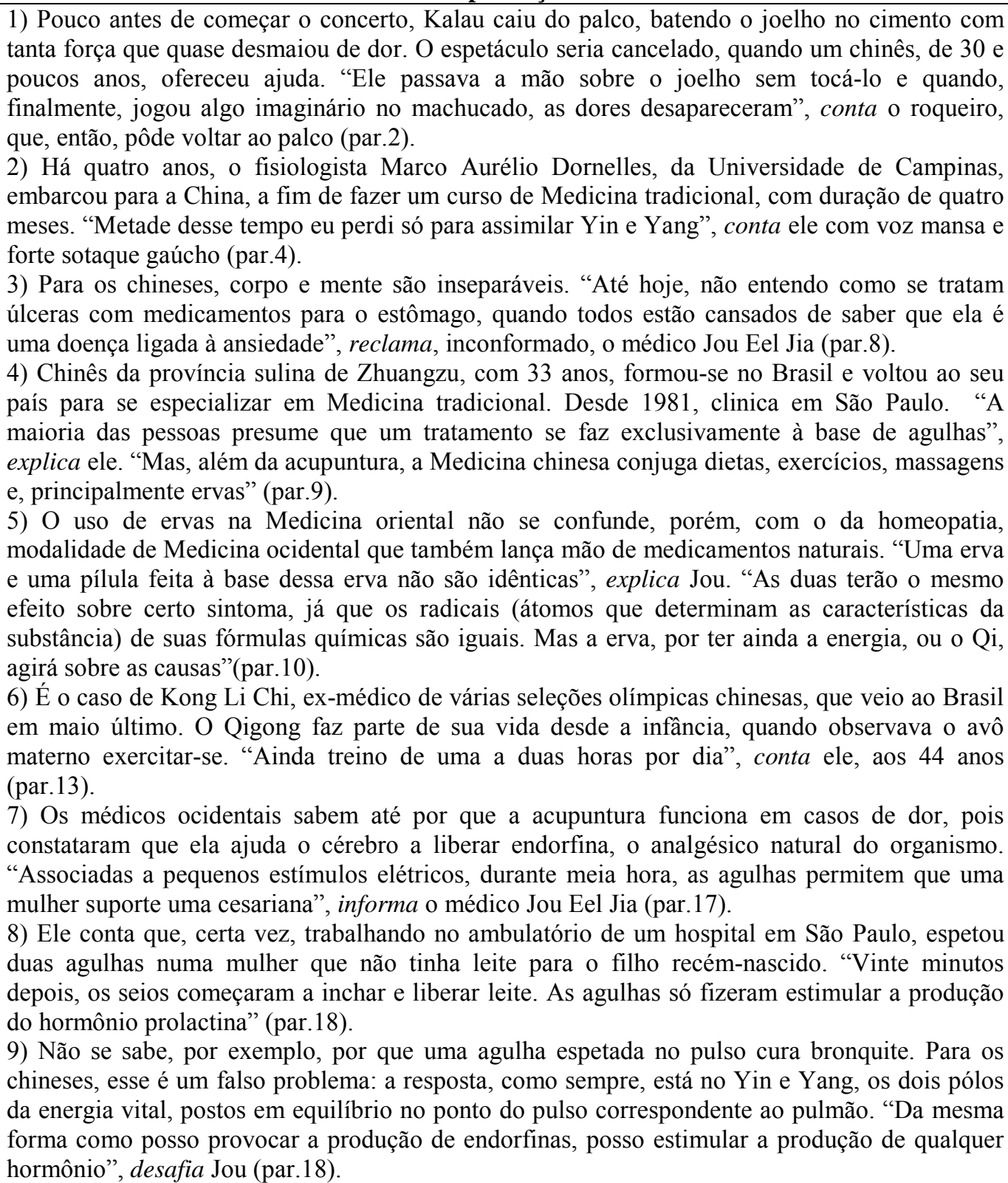 \\
\hline $\begin{array}{l}\text { Discurso Indireto } \\
\text { Analisador } \\
\text { do Conteúdo } \\
\text { (com verbos de } \\
\text { elocução) } \\
\end{array}$ & $\begin{array}{l}\text { 1) O médico paulista Júlio Abranczyk conta, impressionado, que num congresso internacional de } \\
\text { cardiologia, em Washington, há dois anos, os chineses relataram um estudo sobre mil casos de } \\
\text { cirurgia de troca de válvulas cardíacas (par.17). }\end{array}$ \\
\hline $\begin{array}{l}\text { Discurso Indireto } \\
\text { Analisador } \\
\text { do Conteúdo } \\
\text { (com } \\
\text { modalizadores) }\end{array}$ & $\begin{array}{l}\text { 1) Yin e Yan, segundo os orientais, são pólos opostos de uma energia chamada Qi (pronuncia-se } \\
\text { "tchi"), que está presente em tudo no Universo (par.4). } \\
\text { 2) Entre um extremo e outro, de acordo com a Filosofia chinesa, existem cinco diferentes } \\
\text { estados de energia, correspondentes a cinco elementos: madeira, terra, metal, água e fogo } \\
\text { (par.5). } \\
\text { 3) Para os chineses, porém, sem isso nem há medicina. Pois cada uma dessas energias, para eles, }\end{array}$ \\
\hline
\end{tabular}




\begin{tabular}{|l|l|}
\hline controla um dos órgãos que regem a orquestra do organismo - os rins, o baço, o fígado, os \\
pulmões e o coração (par.6). \\
4) Por isso, para a Medicina chinesa, uma doença nunca afeta uma parte do corpo isoladamente \\
(par.7). \\
5) Para os chineses, corpo e mente são inseparáveis (par. 8). \\
6) Para os chineses, esse é um falso problema: a resposta, como sempre, está no Yin e Yang, os \\
dois pólos da energia vital, postos em equilíbrio no ponto do pulso correspondente ao pulmão \\
(par.18).
\end{tabular}

Das nove ocorrências do discurso direto preparado, seis são atribuídas a um especialista em medicina chinesa. Trata-se de Jou Eel Jia que, ao longo da reportagem, é apresentado com uma "mini-biografia":

Chinês da província sulina de Zhuangzu, com 33 anos, formou-se no Brasil e voltou ao seu país para se especializar em Medicina tradicional. Desde 1981, clinica em São Paulo.

É essa "mini-biografia" presente no contexto narrativo que permite a esse médico ter um número grande de citações em forma de discurso direto. É como se sua formação legitimasse suas palavras que estão presentes nos discursos citados.

As outras três ocorrências pertencem, respectivamente, a um guitarrista de uma banda alemã de rock que, apresentando-se na China, foi tratado por um chinês que aplicou nele técnicas da medicina chinesa; a um fisiologista, estudante da Unicamp que foi para a China com a finalidade de fazer um curso em medicina tradicional; a um médico chinês que veio ao Brasil em maio de 1988.

Todas estas três ocorrências também servem para dar voz à prática da medicina chinesa no Ocidente a qual, na década de 80 , estava se abrindo a este tipo de medicina. A reportagem da Super divulga essa recente abertura e, para familiarizar o leitor, começa a reportagem contando casos de pessoas ocidentais (o guitarrista da banda alemã e o fisiologista brasileiro) que passaram por experiências com esse tipo de medicina. Depois de dar voz a essas experiências, por meio do discurso citado, dá voz aos especialistas em medicina chinesa. Estabelece-se, assim, um diálogo entre o contexto narrativo cujo objetivo é justamente falar da medicina chinesa, e os discursos citados nele presentes que também falam da medicina chinesa. Como se vê, diferentemente da primeira reportagem analisada, esta não dá tanto espaço às vozes de outras esferas da atividade humana. Há, além dessas experiências, um ditado que se situa na primeira linha da reportagem e funciona como elemento de diálogo com o leitor:

Problemas não escolhem hora nem lugar, diz o ditado. 
A revista apropriou-se do ditado, já que ele não tem autor, é anônimo, pertence a todos, à ideologia do cotidiano. Daí a falta de aspas.

Em relação à primeira ocorrência de discurso indireto analisador do conteúdo, poderíamos, num primeiro momento, pensar que se trata de discurso indireto analisador da expressão que mostra não tanto o que o autor disse, mas como ele disse aquilo que disse. Essa interpretação viria do adjetivo impressionado que nos cria uma imagem do modo como o autor citado falou. Entretanto, trata-se de discurso indireto analisador do conteúdo que visa a dar importância ao conteúdo semântico das palavras do autor do discurso citado, o médico paulista Júlio Abranczyk.

O modo como ele disse algo entra, no discurso indireto como conteúdo analisado por um verbo de elocução e acaba por colaborar com o conteúdo semântico do que foi dito. Nas palavras de Bakhtin/Voloshinov:

A variante analisadora do conteúdo apreende a enunciação de outrem no plano meramente temático e permanece surda e indiferente a tudo que não tenha significação temática. Os aspectos da construção verbal formal que têm uma significação temática, isto é, que são necessários à compreensão da posição semântica do falante, são transformados de maneira temática [...] ou então são integrados no contexto narrativo, como uma característica formulada pelo autor" (1929/2004, p.161).

Integrado no contexto narrativo, o adjetivo impressionado dialoga com um dos temas presentes na reportagem: a recente abertura do Ocidente para a medicina chinesa. Júlio Abranczyk é um médico que, em um congresso no próprio Ocidente, ouviu relatos sobre casos bem-sucedidos da medicina chinesa. A presença desse discurso indireto analisador do conteúdo reforça, portanto, o diálogo estabelecido entre o contexto narrado e seus discursos citados.

$\mathrm{Na}$ outra ocorrência, temos novamente o médico Jou Eel Jia falando de uma experiência bem sucedida quando ele utilizou técnicas da medicina chinesa. Se a reportagem se valesse, nesta fala, do mesmo adjetivo da outra (impressionado), a apresentação da medicina chinesa como a "ciência do equilíbrio" estaria comprometida, uma vez que esse adjetivo carrega o traço semântico de surpresa, característica que, para uma medicina milenarmente conhecida, não cabe. Novamente, portanto, cria-se um diálogo entre discurso citado e contexto narrativo que pretende mostrar ao leitor uma medicina alternativa, milenarmente conhecida.

Nas várias ocorrências de discurso indireto analisador do conteúdo com modalizadores, temos os chineses como autores atribuídos a estes discursos. Essa generalização pode apontar para duas interpretações: a primeira é que as técnicas da medicina chinesa são um 
saber conhecido de todo povo chinês, trata-se de uma filosofia, de uma cultura, de um saber socializado por todo este povo. A segunda interpretação nos levaria a acreditar que, além do médico chinês Jou Eel Jia, outros médicos chineses foram ouvidos pela revista para a produção da reportagem. Assim como na edição anteriormente analisada, o discurso indireto analisador do conteúdo com modalizadores parece ser a forma preferida quando se quer transmitir a fala de uma entidade, de uma abordagem ou perspectiva: de acordo com a filosofia chinesa, para a medicina chinesa. De qualquer modo, esses discursos servem, igualmente, para dialogar com o contexto narrativo cujo objetivo é divulgar o que é e como funciona essa medicina.

Ao se valer do discurso direto preparado, a revista, ao antecipar o tema que virá assemelha-se à voz dos especialistas, como no exemplo a seguir, em que a primeira parte cabe perfeitamente na voz de um especialista também:

O uso de ervas na Medicina oriental não se confunde, porém, com o da homeopatia, modalidade de Medicina ocidental que também lança mão de medicamentos naturais. "Uma erva e uma pílula feita à base dessa erva não são idênticas", explica Jou. "As duas terão o mesmo efeito sobre certo sintoma, já que os radicais (átomos que determinam as características da substância) de suas fórmulas químicas são iguais. Mas a erva, por ter ainda a energia, ou o Qi, agirá sobre as causas"(par.10).

Porém, ao utilizar o discurso indireto analisador do conteúdo, mantém-se uma distância entre as palavras dos especialistas e as palavras do contexto narrativo. Esse jogo "aproximação $\mathrm{x}$ distanciamento" parece ser uma característica dessas reportagens.

Vamos às próximas análises para a verificação dessa hipótese.

\subsubsection{Superinteressante - maio de 1989}

Esta reportagem possui 6 páginas, 1 desenho, 1 pintura, 4 fotos e 4 boxes ("Gordos \& Magros de peso", “O engodo das dietas", “Como o corpo aplica o seu capital”, “A vantagem dos bichos”). Há 23 parágrafos dos quais os primeiros 4 fazem parte da introdução. Os outros vêm em blocos, dividindo a reportagem. Esses blocos possuem um sub-título: "A chave do equilíbrio é gastar tudo que se ganha" (par.5-7); "Estresse faz o organismo consumir mais energia” (par.813); "Gula talvez esteja ligada a uma disfunção hormonal" (par.14-16); "O gordos se inquietam menos do que os outros" (par.17-22); "Entre os 20 e os 50 anos, um acréscimo de 12 quilos" (par.23). Igualmente às edições anteriores, esta forma de articular a reportagem pertence à forma composicional do gênero reportagem de capa de divulgação científica da Super e está relacionada às escolhas que a revista faz para compor a reportagem com base no leitor-alvo. 
Os discursos citados que aparecem na reportagem são os seguintes:

\begin{tabular}{|c|l|}
\hline Tipo de discurso & \multicolumn{1}{c|}{ Reprodução } \\
\hline $\begin{array}{c}\text { Discurso Direto } \\
\text { Preparado }\end{array}$ & $\begin{array}{l}\text { 1)Recentemente, ao completar 50 anos, um responsável pai de família resolveu fazer um } \\
\text { seguro de vida. "Nunca se sabe o que pode acontecer", raciocinou sensatamente. Dirigiu- } \\
\text { se então a uma companhia de seguros indicada por um amigo. Escolhido o plano de } \\
\text { pagamento, o cliente assustou-se com a quantia que teria de desembolsar todo mês. "Mas } \\
\text { isso é muito mais do que meu amigo paga, no mesmo plano", reclamou. (par.1) }\end{array}$ \\
2)Trata-se, segundo o psiquiatra Sérgio Bettarello, da Universidade de São Paulo, de um \\
comportamento aprendido na infância: "Se a mãe alimenta o filho toda vez que ele chora, \\
a comida pode virar um substituto para outras emoções". (par.11). \\
3)Isso pode acontecer no caso de pessoas que gastam menos energia ao se alimentar. \\
"São indivíduos que aproveitam melhor os alimentos, devido a uma causa não muito bem \\
esclarecida", diz Halpern. (par.14).
\end{tabular}

Como se observa, esta reportagem possui um número pequeno de discursos citados em relação às outras duas reportagens. O discurso direto preparado aparece somente três vezes, sendo que a primeira ocorrência é voz não da ciência, mas da ideologia do cotidiano que, como nas outras reportagens, também serve como apelo à leitura e diálogo com o leitor.

A única ocorrência de discurso indireto analisador da expressão também se refere à voz da ideologia do cotidiano, embora a expressão que esteja entre aspas se pareça mais com expressão de cientistas:

Muitos gordos, por exemplo, juram, sem ir ao médico, que seu sofrimento é fruto de uma "disfunção glandular" (par.23).

Neste exemplo, nota-se, portanto, a convivência de dois discursos em um mesmo período. Há uma internalização do discurso da ciência pela ideologia do cotidiano neste período. Entretanto, isto é feito de forma irônica pela voz da revista que, ao colocar discurso científico na voz de um indivíduo não cientista, causa certo estranhamento no leitor e até um certo humor. 
Como eles (muitos gordos) podem usar esse discurso mesmo "sem ir ao médico", mesmo sem ler a revista Superinteressante? A escolha do discurso indireto analisador da expressão para transmitir esse discurso citado cabe perfeitamente aos propósitos da revista de ser a única, além, é claro, da própria esfera da ciência, a ter a legitimidade para usar o discurso científico. Na voz dos outros, esse discurso é estranho.

As três ocorrências de discurso indireto analisador do conteúdo têm a presença de modalizadores, garantindo distância e autenticidade à voz dos cientistas.

Embora apareça poucas vezes em forma de discurso citado, a voz da ciência está presente no texto por meio de seqüências narrativas ${ }^{27}$, mostrando que a revista utilizou-se deste discurso para legitimar sua fala. Muitos enunciados do texto são construídos de forma que o sujeito seja "os cientistas", "os pesquisadores":

1) A Medicina tem uma tonelada de respostas para dúvidas desse gênero (par.3);

2) Os cientistas já conseguiram demonstrar, por exemplo, que a hiperfagia - a vontade irresistível de comer - pode estar relacionada às substâncias liberadas pelo hipotálamo (par.15);

3) Os cientistas já observaram que os gordos geralmente têm menos atividade do que os magros - entendendo-se por atividade física tudo que se faz com o corpo (par.16);

4) Uma pista importante para se compreender melhor parte desses aparentes contra-sensos surgiu recentemente nos Estados Unidos: pesquisadores verificaram que pessoas mais gordas apresentam menos movimentos involuntários do que as outras (par.17);

5) Uma pesquisa sobre obesidade, realizada pouco tempo atrás na França, revelou que 69 por cento dos entrevistados, todos gordos, tinham pelo menos um dos genitores com problemas de gordura: outros 18 por cento tinham pai e mãe na mesma situação (par.19);

6) De fato, outros estudos com gêmeos univitelinos - originários de um único óvulo - mostram que o irmão mais pesado ao nascer tende a se tornar obeso em adulto (par.22).

Todos esses enunciados mostram que a revista recorreu a pesquisas, estudos e cientistas para escrever a reportagem dando o efeito de sentido de realidade do discurso da ciência e assegurando-lhe autoridade.

A grande novidade é a presença do discurso direto substituído que serve a duas vozes diferentes: à do leitor e à da revista. Essas perguntas cabem perfeitamente em duas entoações, aproximando o leitor da reportagem. O próprio título da capa, em uma de suas interpretações, pode ser lido como discurso direto substituído (quem é quem na balança (?)).

A utilização desse tipo de discurso citado confere uma aproximação com a voz do leitor que acaba dialogando quase que concretamente com a reportagem. Só que esse diálogo é

\footnotetext{
${ }^{27}$ Fossey (2006) nomeia essa construção estrutura narrativa: "classificamos como estrutura narrativa fragmentos que apresentam características textuais semelhantes às de uma narração literária: têm personagens (pesquisadores), narrador (jornalista), uma seqüência de fatos (o que fizeram/observaram/consideram os pesquisadores) e verbos na $3^{\mathrm{a}}$ pessoa" (p.67).
} 
assimétrico: o leitor tem dúvidas, por isso faz perguntas. A ciência tem as respostas que são dadas por meio da revista:

Por que uns parecem viver permanentemente em regime de greve de fome e ainda assim perdem todas as batalhas contra a balança? E por que outros se deliciam, sem sentimentos de culpa, com uma porção extra de torta de chocolate e ainda assim permanecem esbeltos? A Medicina tem uma tonelada de respostas para dúvidas desse gênero (par.3).

A não-utilização de muitos discursos diretos preparados gera uma economia de espaço na reportagem que, sem ter de ficar a todo instante legitimando, por meio da voz de um especialista, o que já fora falado antes pela revista, pode discorrer sobre vários outros tópicos desse mesmo assunto, tentando não só aprofundá-lo como também dar conta de sua complexidade ${ }^{28}$.

Entretanto, ainda que não apareça em forma de discurso direto preparado, a voz da ciência está bastante presente na reportagem.

\subsubsection{Superinteressante - novembro de 1989}

Esta, que constitui a última reportagem do primeiro período, discorre sobre o sangue. A reportagem procura falar quais os elementos que o compõem, por que ele é tão importante, o que fazer para não perdermos, entre outros. Para dar conta de tudo isso, a reportagem se compõe de 2 enormes desenhos explicativos, 9 fotos, 2 boxes ("Uma gota de verdade", "Quando o sangue sobre à cabeça"), 26 parágrafos divididos em uma introdução (par.1-2), mais 6 blocos encabeçados por sub-títulos: "Só há pouco os cientistas descobriram a célula-mãe” (par.3-4); "No Brasil, em cada cinco homens um é anêmico" (par.5-6); "Sobrevive-se com metade dos glóbulos vermelhos” (par.7-10); "Um coágulo de 2 milímetros pode provocar um infarto” (par.11-17); “As processadoras permitem doações especializadas" (par.18-23); "O sangue artificial é uma fascinante promessa" (par.25-26). Esse "esqueleto" é a forma composicional do gênero reportagem de capa de divulgação científica que, assim dividida, pode obter uma avaliação positiva do leitor em relação ao consumo deste tipo de revista.

Os discursos citados que apareceram estão na tabela a seguir:

\begin{tabular}{|c|l|}
\hline Tipo de discurso & \multicolumn{1}{|c|}{ Reprodução } \\
\hline $\begin{array}{c}\text { Discurso Direto } \\
\text { Preparado }\end{array}$ & $\begin{array}{l}\text { 1)A rigor, os cientistas consideram o sangue um tecido, cujas partículas sólidas, as } \\
\text { células, estão submersas em um meio líquido de cor amarelada, o plasma, formado } \\
\text { basicamente por água. "O plasma é importantíssimo", explica o hematologista Dalton }\end{array}$ \\
\hline
\end{tabular}

\footnotetext{
${ }^{28}$ As primeiras duas reportagens são assinadas pela jornalista Lúcia Helena de Oliveira. Esta terceira reportagem analisada é assinada pelo jornalista Marcelo Macca. Como se verá, as duas primeiras e a próxima a ser analisada, também assinada por Lúcia Helena de Oliveira, possuem mais semelhanças como, por exemplo, um maior número de discurso direto preparado e menos diálogo com o leitor.
} 


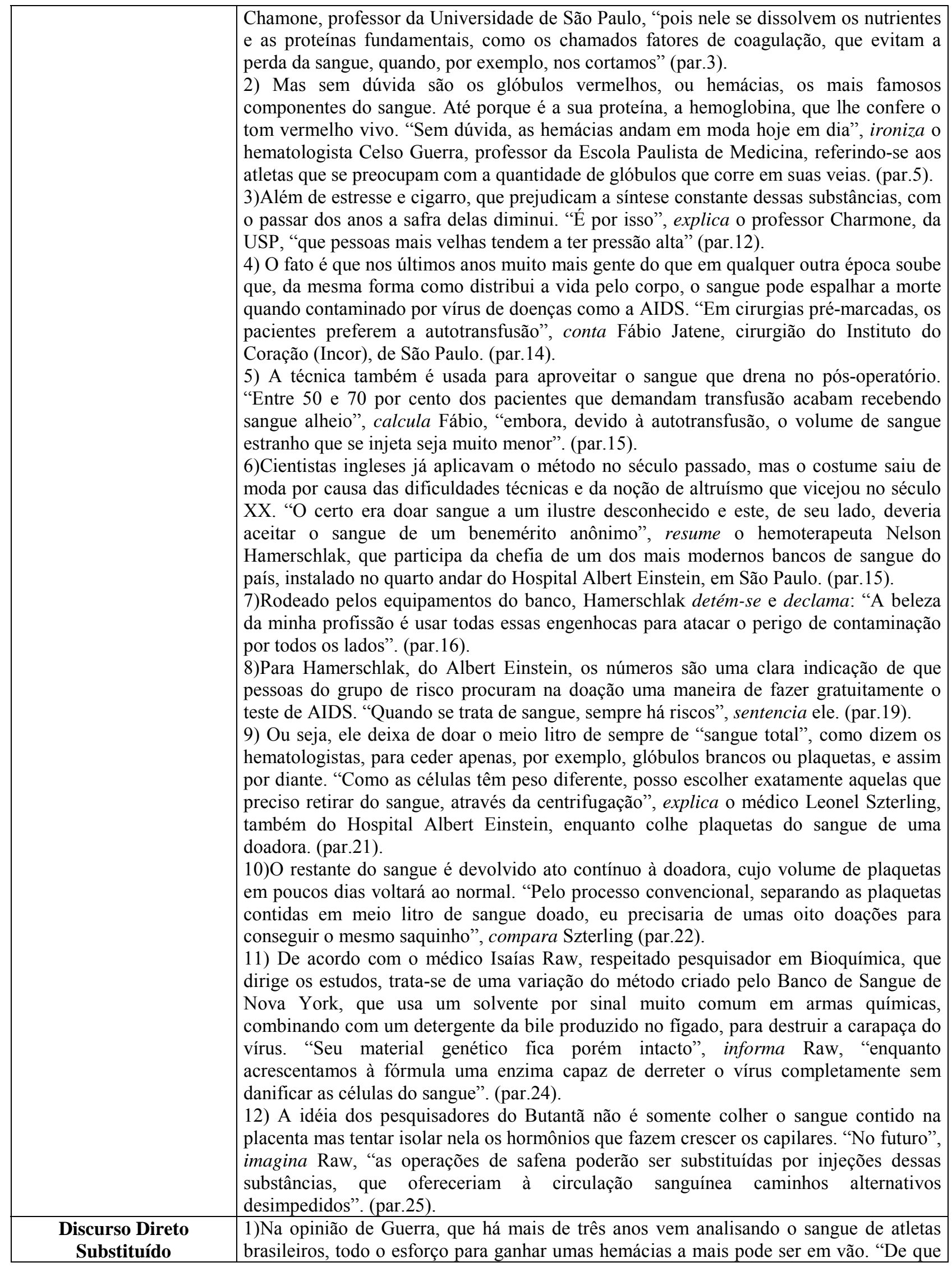




\begin{tabular}{|c|l|}
\hline & $\begin{array}{l}\text { adianta ter glóbulos vermelhos se dentro destes não há ferro suficiente para carregar } \\
\text { oxigênio?", pergunta. De fato, é por falta deste mineral no cardápio do dia-a-dia que um } \\
\text { em cada cinco brasileiros é anêmico. (par.6). }\end{array}$ \\
\hline $\begin{array}{c}\text { Discurso Indireto } \\
\text { Analisador da Expressão } \\
\text { (com modalizadores) }\end{array}$ & $\begin{array}{l}\text { 1)Como diria o diabo do romance Fausto, do poeta alemão Goethe, “o sangue é mesmo } \\
\text { um suco muito peculiar" (par. 26). }\end{array}$ \\
\hline
\end{tabular}

Verifica-se um aumento, em relação às outras reportagens, de ocorrências do discurso direto preparado (12 ocorrências) e uma diminuição de discurso indireto analisador do conteúdo, que, nesta reportagem, não registra nenhuma ocorrência. Isso pode apontar para uma tendência para os próximos períodos, uma vez que, ao citar o discurso dos cientistas valendo-se do discurso direto preparado, a revista dá ao leitor mais credibilidade às informações transmitidas. Além disso, os verbos de elocução utilizados na transmissão desses discursos, nesta reportagem do mesmo modo que nas outras, colocam o cientista no lugar daquele que detém um saber: explica, calcula, resume, declama, sentencia, compara, informa, imagina.

De todos esses, declamar, sentenciar e imaginar fogem um pouco do efeito de sentido de objetividade que possuem os outros. Declamar, segundo o dicionário Houaiss, significa "dizer (texto poético ou retórico) em voz alta, dramatizando o conteúdo com gestos, expressões faciais e modulação de voz; recitar”. Assim, parece que o cientista se valeu de gestos para discursar sobre algo. De fato, ele estava rodeado por equipamentos e, ao falar deles, deve ter apontado com orgulho:

Rodeado pelos equipamentos do banco, Hamerschlak detém-se e declama: "A beleza da minha profissão é usar todas essas engenhocas para atacar o perigo de contaminação por todos os lados". (par.16).

Sentenciar carrega em sua semântica a acepção de emitir ou pronunciar uma sentença que, por sua vez, pode ser entendida como um julgamento ou uma decisão encerrada. Ao utilizar esse verbo de elocução para transmitir o discurso de um cientista, a revista, além de mostrar que ele detém um saber que o leitor não tem, mostra também que só os cientistas são capazes de decidirem e darem o julgamento final sobre determinados assuntos.

Imaginar também não causaria o efeito de sentido de credibilidade, não fosse pelo fato de o cientista estar fazendo previsões futuras e não falando de algo que ele só imagina saber no presente sobre sua especialidade:

"No futuro", imagina Raw, “as operações de safena poderão ser substituídas por injeções dessas substâncias, que ofereceriam à circulação sanguínea caminhos alternativos desimpedidos”. (par.25). 
O discurso direto substituído, muito presente na reportagem anterior, também aparece aqui. Entretanto, a dúvida da autoria é um pouco menor, dadas algumas pistas como o contexto narrativo e as aspas. Trata-se de uma pergunta formulada pelo cientista, mas que caberia perfeitamente na voz do jornalista. O que vem logo após a pergunta é uma explicação para a dúvida que havia sido colocada na questão. Só que, estranhamente, não vem em forma de discurso citado. Assim, neste trecho, há uma inversão de papéis: o cientista perguntou e a revista respondeu, o que gera não só uma valorização da revista como também um estranhamento e uma ruptura nas seqüências descritivas e explicativas do contexto narrativo, por causa da presença do discurso direto substituído:

Na opinião de Guerra, que há mais de três anos vem analisando o sangue de atletas brasileiros, todo o esforço para ganhar umas hemácias a mais pode ser em vão. "De que adianta ter glóbulos vermelhos se dentro destes não há ferro suficiente para carregar oxigênio?", pergunta. De fato, é por falta deste mineral no cardápio do dia-a-dia que um em cada cinco brasileiros é anêmico. (par.6).

Há, ainda, a presença de um discurso citado em forma de discurso indireto analisador da expressão trazendo a voz da Literatura para falar do sangue:

Como diria o diabo do romance Fausto, do poeta alemão Goethe, "o sangue é mesmo um suco muito peculiar" (par. 26).

A função dessa voz é, como a de Charles Baudelaire na primeira reportagem, dialogar com os conhecimentos presumidos do leitor, mas, ao mesmo tempo, legitimar a voz da ciência como a única que tem poder e conhecimentos suficientes para falar do sangue. Na primeira reportagem analisada, a voz da Literatura também apareceu citada na forma de discurso indireto analisador da expressão, variante que muda a "cor" em relação ao contexto narrativo, mostrando que este não quer se misturar a outras vozes, a menos que seja a voz da ciência.

\subsubsection{Síntese do discurso citado no primeiro período}

Vejamos agora as semelhanças e regularidades encontradas nas reportagens deste primeiro período:

1) para dar voz à ideologia do cotidiano e a outras esferas da atividade humana, como a da arte, a da religião, a da filosofia, a forma preferida foi o discurso indireto analisador da expressão que dá outra "cor" à reportagem. Este tipo de discurso citado deixa claro para o leitor que as expressões colocadas entre aspas não pertencem nem ao contexto narrativo nem à esfera da ciência;

2) há um jogo com a voz da ciência que ora aparece perto da voz da revista e do próprio leitor (discurso direto substituído), ora aparece afastada (discurso direto preparado e discurso indireto 
analisador de conteúdo). O efeito que a aproximação causa é mostrar ao leitor que ele pode entender os assuntos complexos da ciência já que não só a voz da revista como a do cientista estão juntas amenizando a linguagem hermética que caracteriza a ciência ${ }^{29}$. Já o distanciamento causado pelo uso de discurso direto preparado e discurso indireto analisador de conteúdo separa a voz do cientista da do contexto narrativo, contribuindo para a imagem séria não só da ciência como ao tratamento dado à reportagem;

3) os verbos de elocução utilizados tanto no discurso direto preparado como no discurso indireto analisador do conteúdo avaliam e condicionam a recepção da voz da ciência por parte do leitor. Vimos que esses verbos contribuem para a imagem do cientista como aquele que possui um grande conhecimento sobre sua especialidade e para a imagem da ciência como a única esfera que pode falar do tema da saúde com propriedade e autoridade. O uso desses verbos, portanto, revela uma tendência social, isto é, o lugar de destaque e prestígio que a nossa sociedade oferece à esfera da ciência;

4) o uso de discurso direto substituído, nas duas últimas reportagens, oferece um diálogo maior com o leitor cuja voz, por meio desse tipo de discurso citado, é incluída no texto, ainda que de forma assimétrica;

5) a presença do discurso da ideologia do cotidiano, por meio de provérbios e falas do senso comum, funcionando como discursos que facilitam o discurso da ciência que é geralmente de difícil entendimento. Esse "ir e vir" do discurso da ideologia do cotidiano para o discurso da ciência e vice-versa tem como função facilitar a leitura e fazer o leitor perceber que a ciência que estuda a saúde faz parte de seu cotidiano, nesse caso, deduz-se que o leitor deve sempre querer consumir este tipo de conhecimento que, afinal, está ligado à sua vida;

6) a fragmentação da reportagem em muitas partes e todas elas contendo discursos citados parece constituir a forma composicional do gênero reportagem de capa de divulgação científica. Os discursos citados cujos autores não são cientistas, mas pessoas comuns, distribuem-se, preferencialmente, no início da reportagem (as três primeiras edições) ou no final (a última edição analisada). Os discursos citados dos cientistas aparecem mais vezes, mas nunca logo no início.

\footnotetext{
${ }^{29}$ Diz Zamboni que as falas dos cientistas já estão em forma de divulgação quando eles são consultados pelos jornalistas: "Nesse sentido, a entrevista e os depoimentos tomados dos próprios cientistas pelo divulgador já vêm configurados como discurso de DC. Quando transpostos para os textos-produtos-da-DC, revelam uma voz que não coincide com a do discurso científico, uma vez que reproduzem uma fala já vulgarizada" (2001, p.56).
} 
(5)

\section{Análise do segundo período}

Partindo dos pressupostos teóricos do capítulo anterior, inicio agora a análise do segundo período, que se compõe dos anos de 1995 e 1997. Conforme já exposto na metodologia, nem o ano de 1994 nem o de 1996 apresentaram capas cujos temas das reportagens fosse a saúde. Assim como no capítulo anterior, começo com a análise dos elementos do peritexto e, em seguida, parto para os discursos citados nas reportagens.

\subsection{Análise dos títulos e imagens}

\subsubsection{Superinteressante - março de 1995}

Nesta edição, temos o seguinte título: "VITAMINAS. OU VOCÊ TOMA OU VOCÊ PERDE”. Essa estrutura é do tipo dado-novo, semelhante aos títulos do primeiro período, isto é, topicaliza-se um assunto já conhecido do leitor e, depois, fornece-se uma nova informação sobre ele.

Aqui, há um diálogo explícito com o leitor, intensificado pelo uso do dêitico você. O uso desse dêitico de segunda pessoa mostra que está presente no título a função conativa, típica da publicidade, reforçando o caráter comercial da revista.

O uso da conjunção alternativa ou parece estabelecer um "cardápio" de opções para o leitor. Entretanto, uma leitura mais atenta vai nos mostrar que o uso do ou duplo nunca significa outra coisa senão a exclusão de uma das opções: ou uma coisa ou outra; senão A, então B. O uso de ou simples tem a mesma função, mas pode também ter uma leitura inclusiva como, por exemplo, na seguinte sentença: "Eu quero brigadeiro ou cajuzinho, qualquer um está bom". Ao usar o ou duplo, portanto, enfatiza-se a exclusão de uma das alternativas. Pezatti (1999) diz ainda que há dois usos diferentes de ou exclusivo: o primeiro é o uso da conjunção que causa uma relação sintática simétrica, isto é, "as duas alternativas são mutuamente exclusivas mas equivalentes e independentes uma da outra, permitindo assim a mudança de ordem" (1999, 


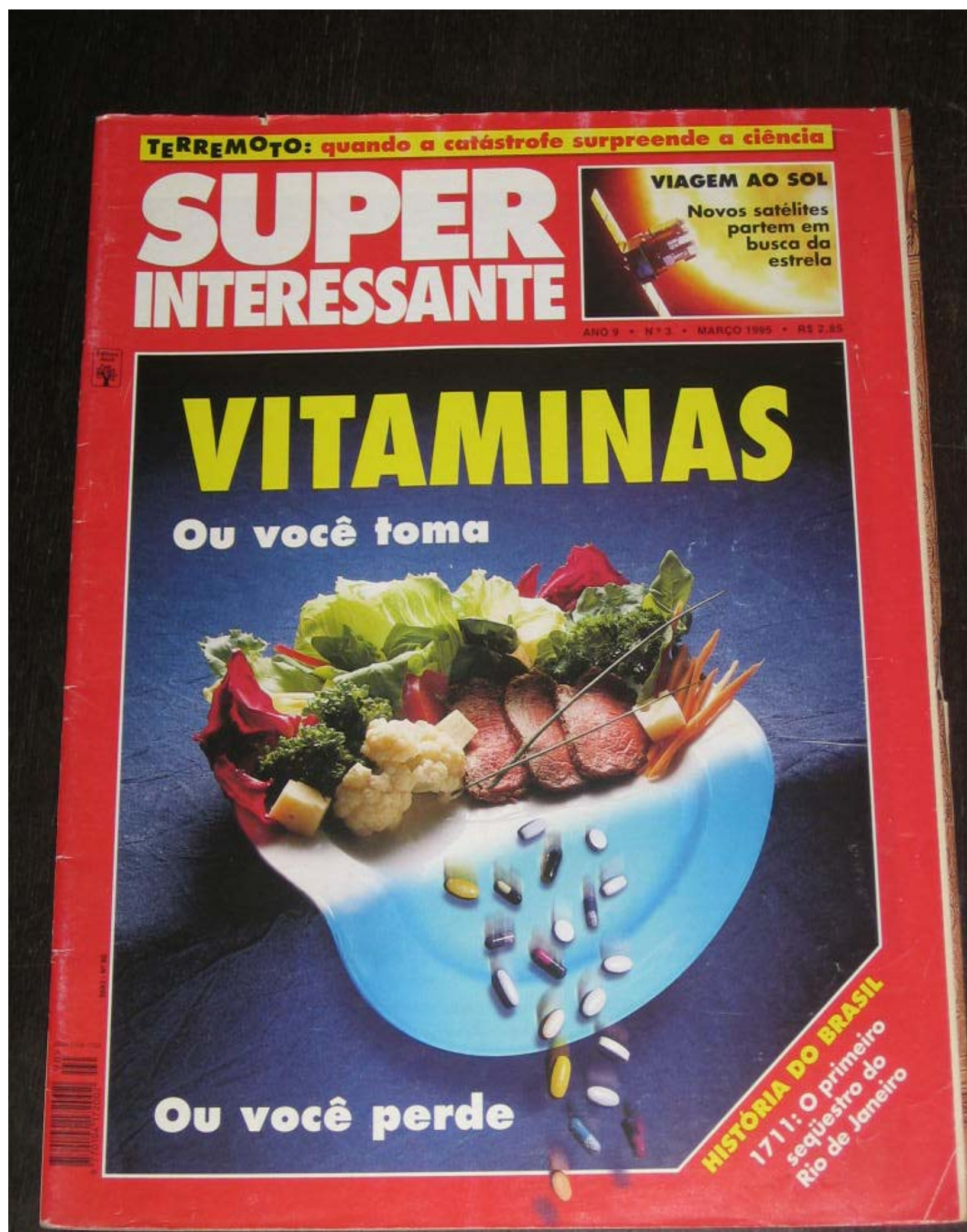


p.429) ${ }^{30}$. Já o segundo uso estabelece uma relação sintática assimétrica. Neste caso, a segunda alternativa depende da primeira e, logo, a inversão é bloqueada. É este o caso do título desta reportagem: a segunda alternativa depende da primeira. Parafraseando, teríamos algo como: se eu não tomar vitaminas, vou perder vitaminas. De acordo com Pezatti (1999),

na disjunção assimétrica [...], o segundo membro da coordenação dá suporte para o enunciado expresso no primeiro membro, de modo que o receptor é obrigado a escolher entre seguir a ordem dada ou ver realizar-se a segunda força ilocucionária, que é um ato de ameaça (1999, p.434).

Penso que neste título, o ato de ameaça não é somente o fato de perder vitaminas caso o leitor não as tomar, mas também perder informações importantíssimas se o leitor não ler a reportagem. Como é provável que ele não vai querer ver realizada a segunda alternativa (ninguém quer perder elementos que são saudáveis para o corpo), ele vai comprar a revista para saber como ele deve ganhar e não perder vitaminas. Esse título dialoga com o leitor através da escolha de alternativas. Entretanto, como se viu, não há propriamente alternativas a serem escolhidas. Embora haja o uso da conjunção alternativa ou, dando a entender que o leitor tem o poder de escolha, esse uso mostrou um caráter de ordem, imperativo. O leitor, na verdade, não tem alternativa, não tem o que escolher: ele deve tomar vitaminas. Mas quais vitaminas? Bom, agora, para saber, o leitor deve comprar a revista. Essa é a verdadeira opção em forma de ordem dada pela revista que o leitor possui.

Em relação aos aspectos não-verbais, temos, na capa, a ilustração de um prato estranhamente dobrado na quina de uma mesa. De um lado, o que está na superfície horizontal da mesa, há alimentos; do outro, o que está dobrado, há comprimidos de vitaminas. As vitaminas, por estarem no lado que está virado para o chão, parecem cair do prato. O efeito dessa ilustração é que se nós comermos comida, teremos apenas 50\% das vitaminas que devemos ter no organismo. Assim, para deixarmos nosso organismo "satisfeito 100\%", devemos ingerir comprimidos de vitaminas, além de comermos os alimentos contidos na ilustração. A ilustração dessa capa capta o leitor pela carência de realidade nela contida: um prato não se dobra, ele se quebra. Não se trata de um prato dobrável, mas de um prato real, assim como as comidas nele contidas. Há uma alusão a um quadro de Salvador Dali “A Persistência da Memória”, de 1931. Trata-se, portanto, de um diálogo não só com a esfera da arte, como também com os

\footnotetext{
${ }^{30}$ Pezatti (1999, p.434) dá o seguinte exemplo para ilustrar o uso de ou exclusivo simétrico: A - João entregou a tese no prazo? B - A gráfica atrasou a encadernação ou ele não fez as correções a tempo.
} 
conhecimentos presumidos do leitor que, ao ver a capa da revista vai associá-la com o quadro de Dali.

A disposição dos sintagmas "OU VOCÊ TOMA"/"OU VOCÊ PERDE" é bastante significativa na parceria entre os aspectos verbais e os não-verbais. Enquanto "OU VOCÊ TOMA" aparece acima, perto dos alimentos do prato e próximo de "VITAMINAS" (sintagma que possui a fonte maior), "OU VOCÊ PERDE” aparece bem embaixo, logo depois da ilustração, em uma leitura superior/inferior. Associamos o verbo "perder" aos comprimidos de vitaminas caindo no chão. Assim, os aspectos verbais e os aspectos não-verbais aliam-se para significar a mesma coisa: se não quisermos "perder", temos de "tomar" vitaminas.

Já o título do interior da reportagem não camufla, como o título da capa, o poder de escolha do leitor. Há uma ordem explícita: "VITAMINAS. VOCÊ TEM QUE TOMAR". Utilizou-se uma fonte bastante grande para a palavra "VITAMINAS", de modo que ela ocupou a parte superior das duas primeiras páginas da reportagem. "VOCÊ TEM QUE TOMAR" aparece também em letras grandes (porém menores que as em VITAMINAS), logo abaixo das letras da palavra "VITAMINAS" que aparecem na segunda página da reportagem.

Na Gramática de Cunha \& Cintra (1985, p.383), lemos que o verbo ter pode ser um verbo auxiliar que, quando empregado com o infinitivo do verbo principal antecedido da preposição de, exprime a obrigatoriedade de realizar o fato. No caso, a preposição de não foi utilizada, mas sim a conjunção que, foneticamente mais forte que o som de: enquanto o som a consoante /k/ é uma oclusiva velar, a consoante /d/, em alguns dialetos, é uma oclusiva alveopalatal. Foneticamente, portanto, também se contribui para a força da ordem contida no sintagma.

Entendida como obrigação, o leitor se sente na também obrigação de ler a reportagem para saber por que ele tem de tomar vitaminas, além de tentar descobrir, por meio da ajuda da revista, alguns caminhos, algumas dicas de quais vitaminas ele deve ingerir.

Tanto o título da capa ${ }^{31}$ quanto o título da reportagem são incisivos na afirmação de que é não só necessário como também obrigatório tomar vitaminas. Diferentemente do título da primeira reportagem do primeiro período $^{32}$ em que o modalizador pode não oferecia certeza quanto ao fato de não sentirmos mais dores, os títulos dessa edição não oferecem nenhuma dúvida ao leitor em relação a tomar ou não tomar vitaminas.

\footnotetext{
${ }^{31}$ Este com o auxílio da ilustração.

32 “DOR. ESTE TORMENTO PODE ACABAR” (Superinterssante - março de 1988).
} 
A revista, nesta reportagem, valeu-se de estratégias mais explícitas de captação do leitor por meio de uma ordem disfarçada de aconselhamento que tem por objetivo fazer o leitor fazer algo, mais do que apenas fazer o leitor saber algo.

\subsubsection{Superinteressante - agosto de 1995}

O título desta capa é "MACONHA. UM REMÉDIO PROIBIDO?". A fonte usada na palavra "MACONHA" é maior e, além disso, esta palavra situa-se na parte superior da capa, dando a ela o maior destaque. No meio e ocupando quase $80 \%$ da capa, há a ilustração de uma erva de maconha que está na frente de quatro tubos de ensaio. Logo abaixo, no canto inferior direito, o sintagma "UM REMÉDIO PROIBIDO?".

Imediatamente, associamos a palavra remédio do título aos tubos de ensaio da ilustração e a palavra proibido do título à erva de maconha da ilustração. Maconha e remédio também se relacionam, uma vez que um remédio retoma anaforicamente o termo maconha: "MACONHA. UM REMÉDIO PROIBIDO?”. Já se pressupõe, portanto, por meio do próprio título, que há benefícios trazidos pela maconha em forma de remédio.

Questiona-se se é possível aquilo que é proibido por fazer o mal ser liberado para fazer o bem. Este período em forma de pergunta remete a um tipo de discurso citado, o discurso direto substituído, que ocorre quando alguém toma a palavra no lugar do outro. No caso, a voz da revista apresenta aquilo que ela e o leitor poderiam perguntar. Entretanto, esse discurso citado substituído parece fazer mais um paralelismo entre a voz da revista e a voz proveniente do discurso científico, já que os cientistas estão em dúvida sobre a comercialização legal dos remédios feitos com essa erva.

Flexionada no particípio, a palavra proibido pressupõe um agente que proibiu o uso do remédio. Trata-se da proibição das drogas pelo governo. Há, aqui, um diálogo entre a esfera da ciência e a esfera da política. Assim, em cada esfera da atividade humana, um mesmo termo é entoado de diferentes maneiras. De um lado, o governo considerando a maconha ilícita. De outro, os cientistas descobrindo os benefícios e as curas que a maconha pode proporcionar. Exemplo clássico de um signo se tornando uma arena, já que, como afirmam Bakhtin/Volshinov, “(...) em todo signo ideológico confrontam-se índices de valor contraditórios" (2004, p.46). O próprio sintagma em forma de pergunta (“UM REMÉDIO PROIBIDO?”) faz lembrar essas duas visões 


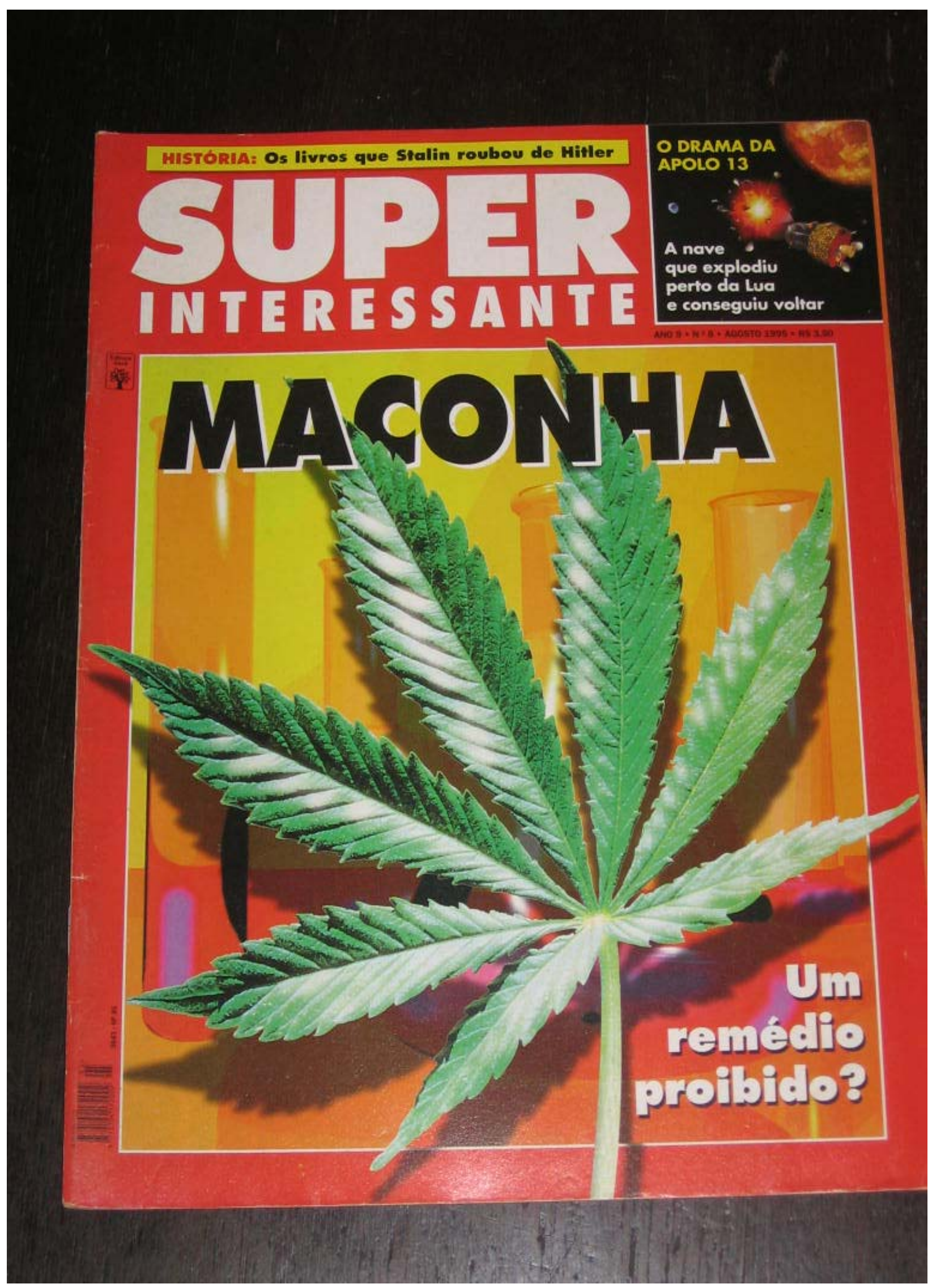


ideológicas por meio das palavras remédio (visão ideológica da ciência) e proibido (visão ideológica da legislação).

Quando analisarmos a presença do discurso citado nesta reportagem, verificaremos se há ou não polifonia (como há no título da capa), para qual esfera a revista dá mais voz e como ela transmite essa voz.

O título do interior da reportagem "QUANDO A MACONHA CURA" ocupa duas páginas. "QUANDO A MACONHA" está na parte superior das páginas e "CURA" está centralizada na parte inferior das páginas. No meio desta parte verbal, aparece mais uma vez a imagem de uma grande erva de maconha.

Este título parece prometer que a reportagem tratará dos benefícios trazidos pela maconha. Portanto, a revista mostrará a voz da ciência e não a do governo, ou seja, o que a ciência está descobrindo na maconha que a torna um remédio e não o que a polícia está investigando para apreender esta droga e prender traficantes.

\subsubsection{Superinteressante - janeiro de 1997}

Este título segue a estrutura dado/novo, igualmente aos do primeiro período.

Embora não haja, nesta edição, o uso do dêitico você, há, juntamente com o título “COSMÉtICOS CIENTÍFICOS. AGORA A BELEZA VIROU ASSUNTO DOS CIENTISTAS", a foto do rosto de uma mulher todo sombreado pela cor azul exceto por duas partes do rosto, destacadas por dois retângulos, em que aparece a cor da pele. Em um retângulo, a altura é maior do que a base e o que se recobre é a parte direita do rosto que vai da testa até o meio da bochecha. Neste retângulo, encontra-se a seguinte parte verbal: "Contra as rugas. Cápsulas minúsculas vão mais fundo, com rejuvenescedores cada vez mais potentes”. Da região onde geralmente aparecem as rugas, sai um círculo com desenhos de células recebendo as cápsulas minúsculas.

Um outro retângulo, com a altura menor que a base, aparece recobrindo toda a boca e ainda a parte da bochecha do lado esquerdo do rosto. De lá, sai um outro círculo com o desenho da superfície da pele recebendo a proteção dos filtros contra os raios solares. À esquerda do rosto e fora dele, a parte verbal: "Novos filtros solares. Eles não deixam a pele nem sequer esquentar e protegem por mais tempo". Como se vê, há uma ênfase ao redor dos olhos e da boca, lugares mais prováveis de rugas aparecerem. 


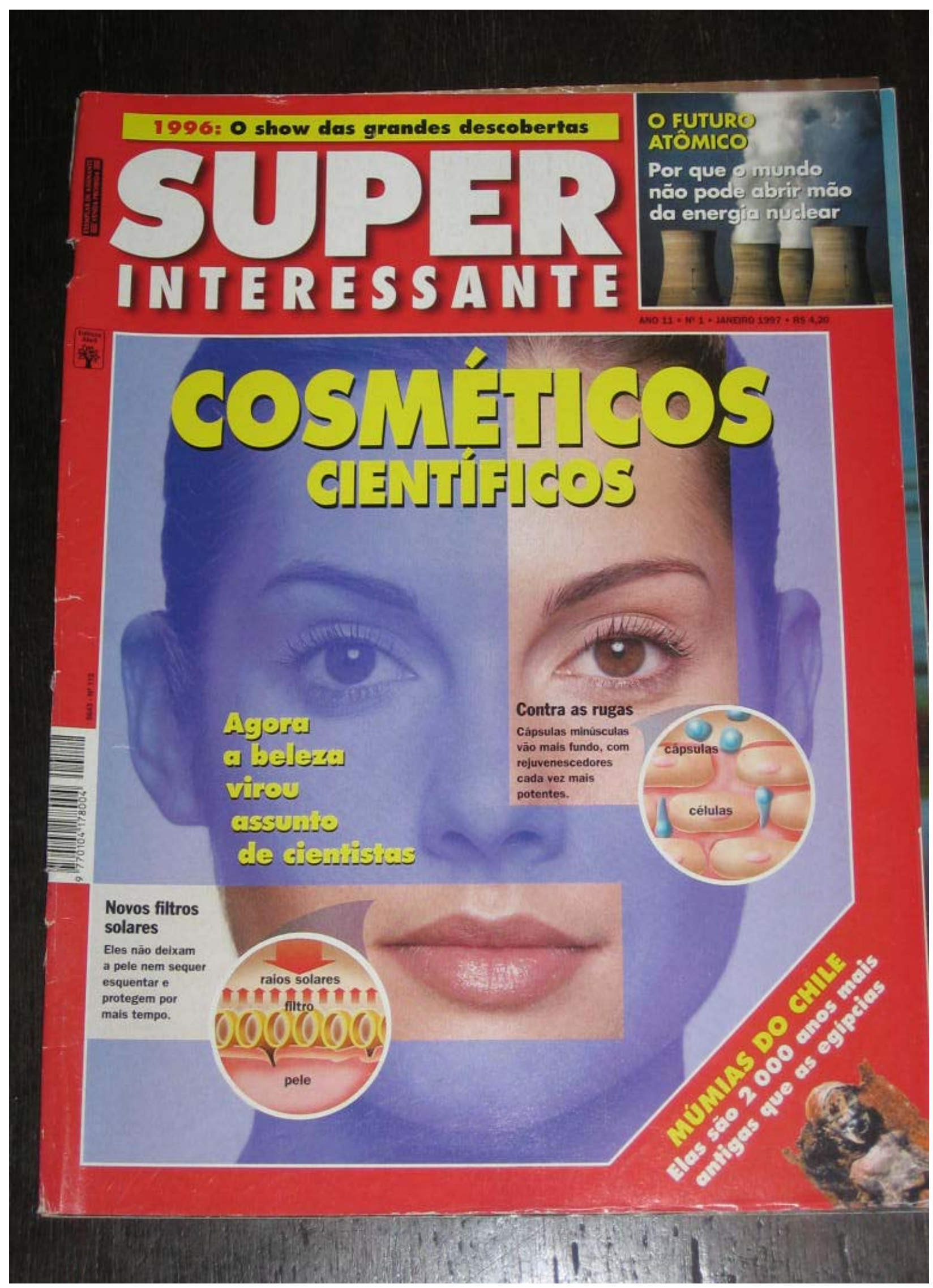


O sintagma "COSMÉTICOS CIENTÍFICOS" encontra-se na parte superior da capa e é o que possui o maior tamanho da fonte. Já o período "Agora a beleza virou assunto de cientistas" aparece no meio, à esquerda, em cima da bochecha do rosto da mulher.

Este título dialoga explicitamente com o leitor ao propor a divulgação de um assunto que é comumente mais associado à ideologia do cotidiano, mas que agora faz parte também da esfera da ciência. Como esse assunto chegou na esfera da ciência, a revista pode divulgá-lo tranqüilamente.

A vantagem que a revista possui nesta edição é que, antes de pertencer à esfera da ciência, este assunto era mais conhecido pela ideologia do cotidiano, privilegiadamente pelo público feminino e, portanto, a captação do leitor é mais imediata, já que este se sente mais familiarizado com o assunto. E que assunto é esse? Trata-se da beleza que agora "virou assunto de cientistas".

No entanto, para revestir a edição de um caráter científico, a beleza aqui não será tratada apenas como uma questão de vaidade (para isso, o Grupo Abril possui outras revistas), mas também e principalmente como uma questão de saúde.

Vale a pena lembrar aqui o que disse Bakhtin sobre o tema nos gêneros do discurso. Para ele, um tema pode ser abordado de diferentes maneiras de acordo com o gênero em que ele aparece. Assim, o tema beleza no gênero programa de TV vespertino voltado ao público feminino será visto como vaidade. A própria foto desta capa, se colocada na capa de uma revista que trata de moda e beleza, voltada exclusivamente ao público feminino, teria outras conotações. Em primeiro lugar, não haveria explicações científicas em cima desse rosto que, aqui nesta capa, parece mecânico, esvaziado de beleza, sensualidade e expressões faciais. Trata-se de um "rosto científico", desprovido de valores culturais como a beleza, por exemplo. Colocada em uma outra situação, em uma outra esfera, como a esfera da moda, por exemplo, esta foto teria outras cores, o rosto dessa mesma mulher seria mais maquiado, a cara estaria mais sexy e o cabelo emolduraria de outra forma esse mesmo rosto. Já no gênero reportagem de capa de revista de jornalismo científico, o tema da beleza será associado à saúde, ou seja, como prevenir a pele de doenças, como deixá-la longe dos efeitos da poluição e, para dialogar mais com o leitor, como manter a pele sempre jovem e bonita, pois parece serem essas as grandes preocupações do leitor. Deste modo, ao "lermos" esta foto, não nos focaremos na beleza dessa mulher, mas sim nos benefícios que a ciência pode trazer para a pele das pessoas. 
Aqui entra em jogo a capacidade de a ciência transformar a beleza em tecnologia: os "cosméticos científicos" foram por ela desenvolvidos para ajudar o leitor a ter uma pele mais bonita e saudável. Exaltam-se claramente a voz e o poder da ciência, sem perder de vista os reais interesses do leitor que não está preocupado exatamente com os avanços da ciência, mas em como esses avanços afetam sua vida e, mais especificamente, a sua beleza.

$\mathrm{O}$ avanço tecnológico da ciência fica especialmente claro nas pequenas explicações que aparecem na própria capa, servindo como um aperitivo, uma amostra do que a ciência é capaz de fazer: "Contra as rugas. Cápsulas minúsculas vão mais fundo, com rejuvenescedores cada vez mais potentes", "Novos filtros solares. Eles não deixam a pele nem sequer esquentar e protegem por mais tempo". O uso de nem sequer enfatiza o poder da ciência uma vez que esse operador joga em uma escala de probabilidades ${ }^{33}$ o termo por ele focado mostrando que "esquentar" que era a ação mais provável de acontecer, não acontece graças aos novos filtros desenvolvidos pela ciência. O uso desse operador argumentativo, portanto, orienta o leitor a chegar à seguinte conclusão: se os filtros solares nem sequer esquentam a pele, muito menos provável é a pele se danificar ou queimar. O uso de nem apenas já faria esta tarefa. Ao combinar nem com sequer enfatiza-se o efeito de sentido deste operador.

As outras palavras utilizadas nestas pequenas explicações como rejuvenescedores e potentes trazem para o leitor o conforto de usar esses cosméticos desenvolvidos pela ciência. Se eles conseguem fazer rejuvenescer cada vez mais, então é bom usá-los uma vez que a sociedade em que vivemos é toda voltada para a juventude. Infelizmente, vivemos em uma sociedade baseada nesses preconceitos que acabam sendo reforçados quando a própria ciência (esfera tão respeitada) pesquisa como podemos parecer mais jovens. Se até a ciência está preocupada com isso, embora diga que a preocupação na realidade é com a saúde e não com a beleza, o leitor se sente na obrigação de cuidar da sua beleza, usar esses cosméticos e, mais uma vez, comprar a revista. Trata-se aqui de um diálogo entre os enunciados de diferentes esferas.

O título do interior da reportagem ocupa a primeira página e está situado na parte superior: "TUDO BELEZA. A CIÊNCIA DOS COSMÉTICOS”. “TUDO BELEZA” possui a

\footnotetext{
${ }^{33}$ Para Jackendoff (1972), as partículas de foco escalar (como até e nem, no português brasileiro) introduzem uma escala de probabilidades, isto é, entre os valores sob consideração, o valor dado pelo elemento focado por nem é o mais provável: Nem os alunos de Iniciação Científica, os mais prováveis de ir a um congresso de lingüística, apareceram. Esta análise aproxima-se da de Ilari \& Geraldi (1999) que consideram nem e até como operadores argumentativos que têm o poder de fazer o interlocutor ser induzido a determinadas conclusões. Assim, os elementos
} 
fonte maior e dialoga imediatamente com o discurso da ideologia do cotidiano, já que este sintagma se refere tanto a uma pergunta quanto a uma reposta numa situação de cumprimento. Aqui, no título, este enunciado pretende não só dialogar com o leitor como também anunciar, por meio do pronome tudo, que a reportagem tratará inteiramente da beleza. O que vem a seguir "A CIÊNCIA DOS COSMÉTICOS" mostra sob qual perspectiva a reportagem tratará disso. Não se trata de maquiagens ou de estados de espírito, mas dos avanços científicos que contribuem não só para a vaidade, mas também e, principalmente, para a saúde.

\subsubsection{Superinteressante - abril de 1997}

Esta edição tem como título "O VENENO DO BEM. CIENTISTAS BRASILEIROS SURPREENDEM O MUNDO COM REMÉDIOS DE SERPENTES”. A ilustração é uma mulher nua, segurando uma maçã, e uma serpente ao seu lado com a boca aberta. O leitor certamente associará esta ilustração ao episódio bíblico de quando a serpente convence Eva a comer o fruto proibido. A serpente, portanto, é vista não só religiosamente como um animal que provoca coisas ruins, mas também como um animal que possui veneno. É esta a imagem da serpente na ideologia do cotidiano. Ao passar pela ideologia da ciência, há uma imagem contrária: o veneno da serpente pode ser uma substância de remédios e, portanto, fazer o bem.

Como passa do mal para o bem, de uma ideologia para outra, o título é constituído por essa antítese: o veneno do bem. Da mesma maneira da edição de agosto de 1995 em que a maconha torna-se remédio. O efeito que essas antíteses causam no leitor é o estranhamento, a relação de contrariedade. Alteram-se os sentidos de veneno e proibido que possuem traços semânticos negativos, mas que, associados a bem e remédio respectivamente, ganham destes traços positivos. Com essas mudanças de sentidos, reordena-se o mundo segundo a visão da ciência.

O efeito de estranhamento também se dá no próprio sistema ideológico da ciência quando lemos no título que "cientistas brasileiros surpreendem o mundo com remédios de serpentes" (grifo meu). Apesar do efeito de surpresa que carrega tanto traços positivos quanto traços

que comporiam uma escala servem, na verdade, como argumentos (mais fortes ou mais fracos) para levar a conclusões. 
negativos (tudo depende da situação), há também o efeito da valorização das pesquisas científicas nacionais: trata-se de uma pesquisa pioneira no Brasil. 


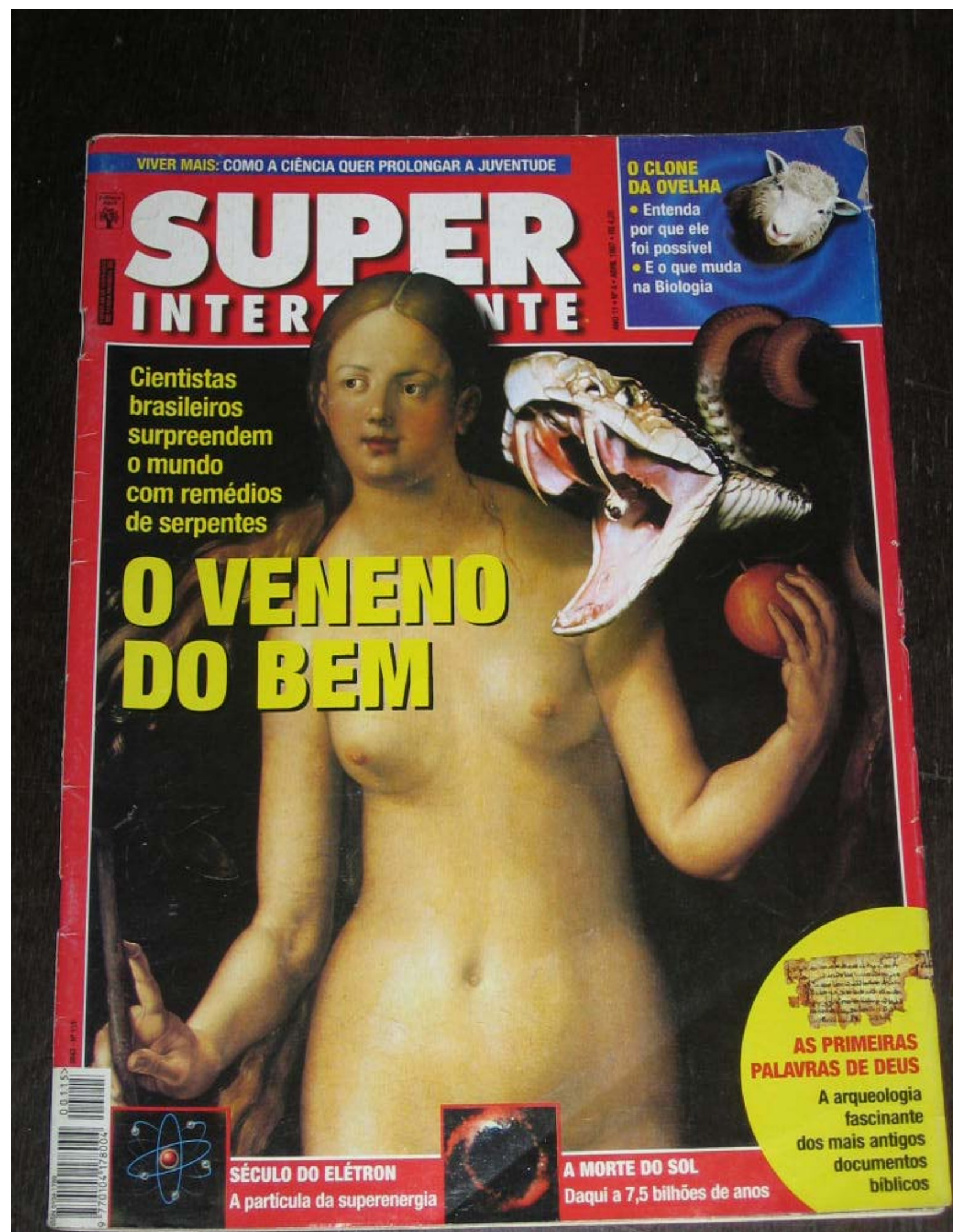


O título do interior é um fragmento do da capa: "O VENENO DO BEM”. Ele ocupa as duas primeiras páginas da reportagem, por possuir fonte em tamanho grande, e situa-se na parte inferior dessas páginas.

Assim como na edição de agosto de 1995 em que há um estranhamento pelo fato de algo considerado mal fazer o bem, aqui também esse efeito é conseguido. Esse estranhamento, contudo, no lugar de dispersar o leitor, aproxima-o, despertando-lhe a curiosidade e também a possibilidade de usufruir novos remédios para a sua saúde.

\subsubsection{Superinteressante - julho de 1997}

Em relação a todos os outros títulos analisados, este é o que possui a maior parte verbal: "NA MIRA DO MOSQUITO ASSASSINO. Ele espalha a malária e mata 1,5 milhão de pessoas por ano. Agora, pesquisadores brasileiros lideram a corrida mundial pela vacina".

A ilustração da capa traz o mosquito causador da doença dentro do desenho do alvo de uma arma. O desenho do alvo remete imediatamente à parte verbal "na mira". Embora seja o mosquito o assassino, como expresso na parte verbal, na ilustração ele se torna vítima. Mas tratase de uma vítima pequena: um inseto. Entretanto, ocupando uma grande área da capa, esse único mosquito parece enorme, torna-se um monstro. Um monstro não só pelo tamanho projetado na capa como também pela tragédia que comete: ele causa uma doença que mata 1,5 milhão de pessoas por ano. Neste caso, a parte verbal "na mira do mosquito assassino" ganha uma outra interpretação: o mosquito é quem está mirando as suas milhares de vítimas.

Certamente, os cientistas não vão destruir todos esses mosquitos com uma arma, mas sim desenvolvendo uma vacina que impeça o ataque deles no sangue, ou seja, a "guerra" é silenciosa e ocorre no interior do corpo. Mesmo assim, a capa consegue o efeito de sentido de uma grande guerra do "bem" (as pessoas e os cientistas) contra o "mal" (o mosquito causador da malária). Trata-se de uma capa que pretende captar o leitor, convocando-o para, juntamente com os cientistas, combater o mosquito.

Além da ilustração, outros sintagmas também contribuem para esse aspecto monstruoso do mosquito: "assassino", "ele espalha a malária e mata 1,5 milhão de pessoas por ano". Neste 
período, temos o verbo espalhar que denota falta de controle por parte daqueles que não querem que algo se espalhe. $\mathrm{O}$ verbo matar também traz traços negativos e associa-se à palavra 


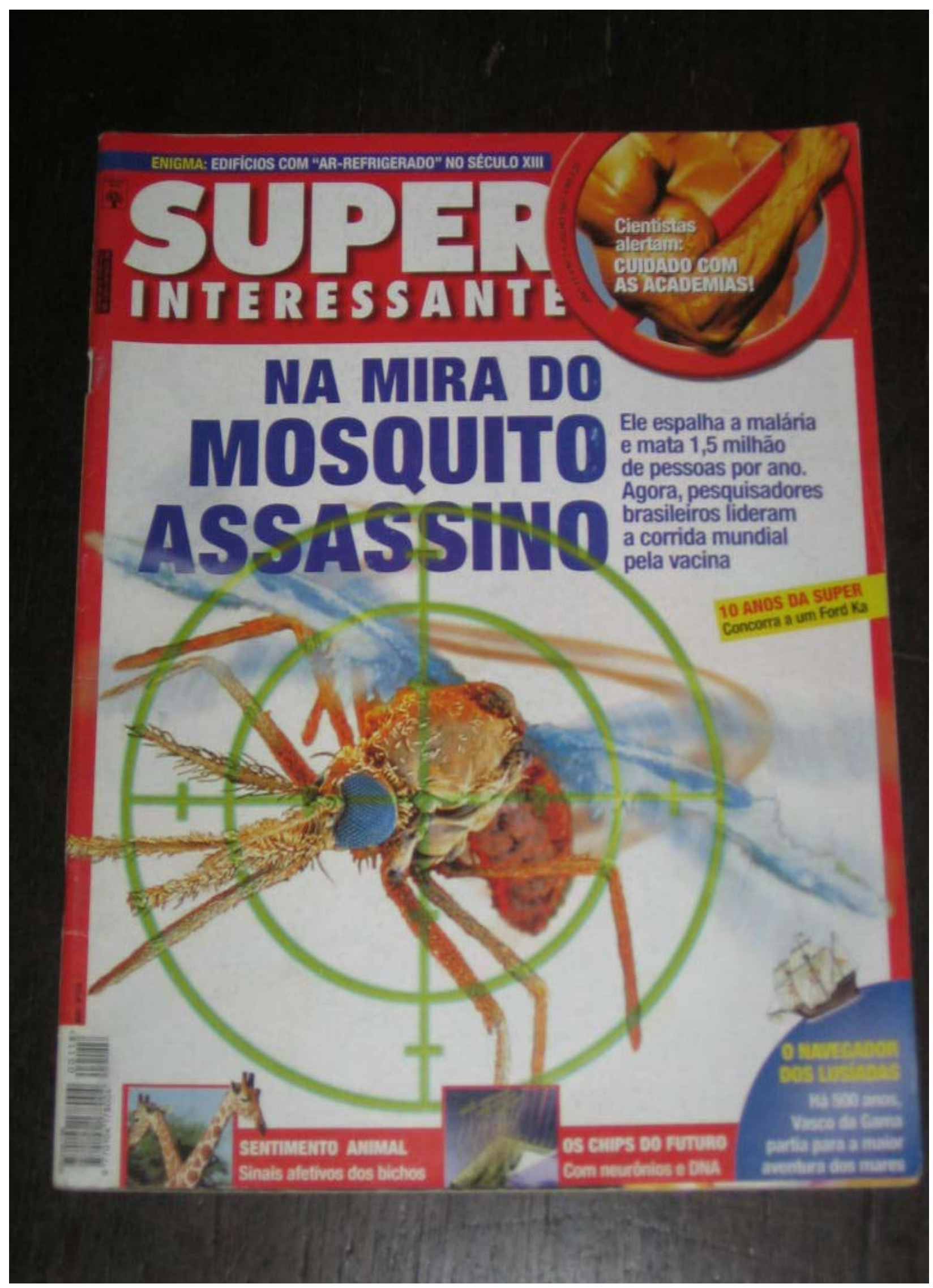


assassino: o assassino é aquele que mata. O número 1,5 de pessoas por ano mostra, em forma de dados, a tragédia que causa esse assassino. Há, na ligação entre os aspectos verbais e não verbais desta capa, uma personificação do mosquito: ele é um assassino que mata.

Assim como no título anterior" ${ }^{34}$, há, por meio do sintagma "Agora, pesquisadores brasileiros lideram a corrida mundial pela vacina", uma valorização da ciência brasileira que está liderando pesquisas sobre a vacina que pode acabar com a malária. Espera-se, portanto, que a voz de cientistas nacionais predomine nos discursos citados.

O título do interior da reportagem é “À SOMBRA DO MOSQUITO”. Ele ocupa as duas primeiras páginas da reportagem, devido ao tamanho grande da fonte, e se localiza na parte superior. Este título também gera o efeito de monstruosidade em relação ao mosquito. Pelo grande mal que causa, ele se torna enorme, capaz de criar uma sombra sob a qual se encontram as vítimas. Uma outra leitura possível é os cientistas estarem à sombra do mosquito, ou seja, eles estão à procura, à caça desse mosquito que, mesmo sendo muito pequeno, está causando várias mortes, dificultando a ação de erradicação da doença pelos cientistas.

Tanto os aspectos verbais quanto os não-verbais unem-se para causar espanto no leitor. Trata-se de um quase sensacionalismo. Em relação às capas do primeiro e do segundo períodos, esta é a que mais trabalha com o medo não só pelos aspectos verbais, mas principalmente com a ligação que estes fazem com os aspectos não-verbais da capa.

\subsubsection{Superinteressante - setembro de 1997}

Esta edição possui o seguinte título: "NO FUNDO DO CORAÇÃO. Uma nova técnica brasileira revoluciona as cirurgias cardíacas". A fonte maior é usada em "NO FUNDO DO CORAÇÃO”. Este sintagma é típico da ideologia do cotidiano quando queremos dizer o quão profundo é o sentimento por algo ou alguém. Ao se valer desta expressão, a voz da revista dialoga com os conhecimentos presumidos do leitor. Este, por sua vez, já espera que a revista não abordará sentimentos que, metaforicamente são sempre associados ao coração, mas sim vai tratar cientificamente do órgão em questão.

\footnotetext{
34 “O VENENO DO BEM. Cientistas brasileiros surpreendem o mundo com remédios de serpentes" (Super - abril de 1997).
} 


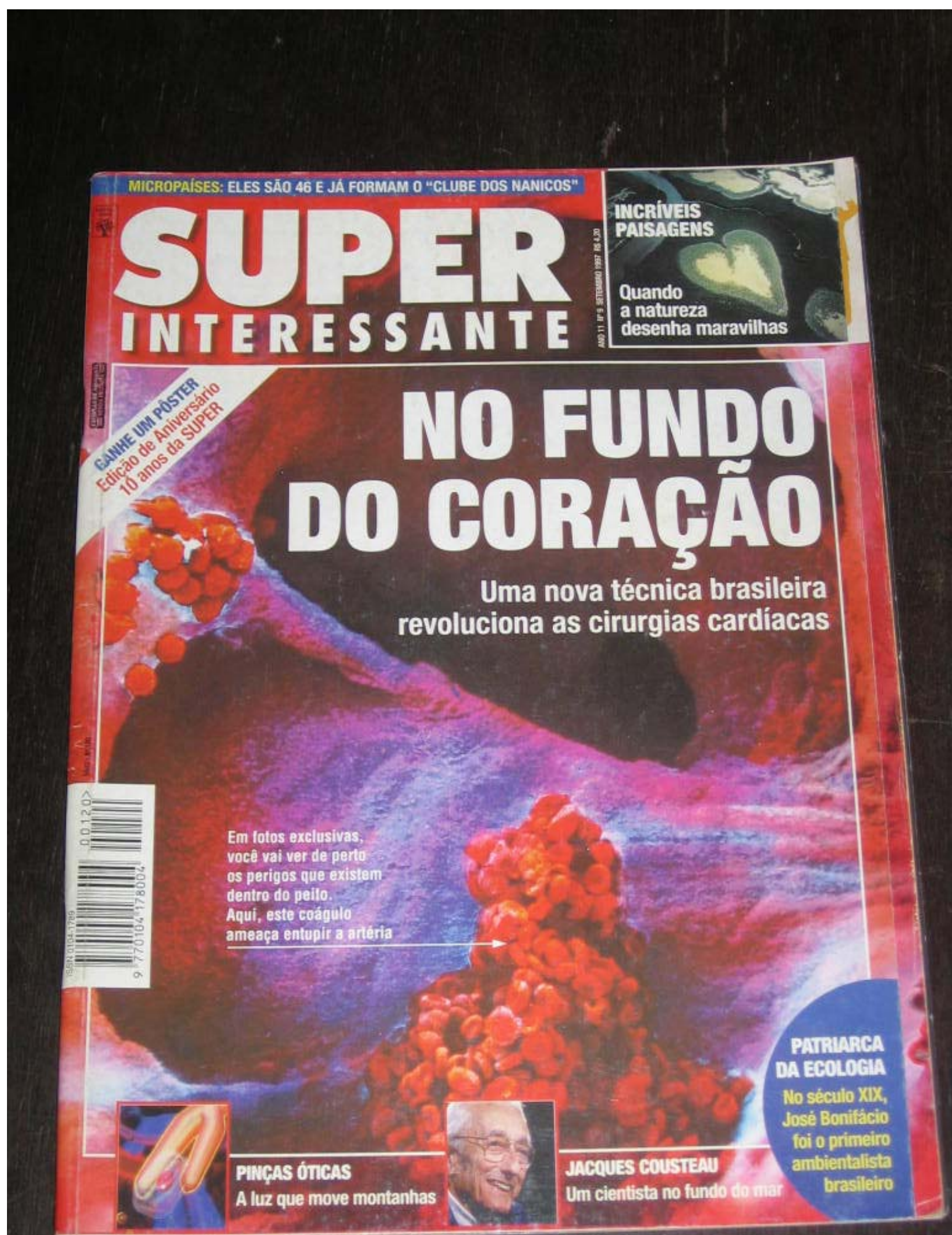


O comentário novo que vem a seguir "Uma nova técnica brasileira revoluciona as cirurgias cardíacas" destaca a pesquisa nacional, garantindo notoriedade aos cientistas brasileiros. Isso ocorreu também nas duas edições anteriores, em que essa valorização é explicitada: "Cientistas brasileiros surpreendem o mundo com remédios de serpentes" (abril de 1997) e “Agora, pesquisadores brasileiros lideram a corrida mundial pela vacina” (julho de 1997).

Surpreender, liderar e revolucionar são todos verbos que carregam traços semânticos positivos no contexto em que foram empregados. Além disso, em relação à esfera da ciência, esses verbos são bastante usados quando há grandes e sérias pesquisas. As cirurgias de coração sempre foram consideradas bastante delicadas; quando alguém as revoluciona, acreditamos que elas tornar-se-ão mais simples, mais rápidas e com bem menos riscos de morte.

A capa traz ainda uma foto do coração humano com o seguinte comentário: "Em fotos exclusivas, você vai ver de perto os perigos que existem dentro do peito. Aqui, este coágulo ameaça entupir a artéria”. Pela segunda vez, na análise do segundo período da revista, aparece o dêitico você que dialoga explicitamente com o leitor, colocando-o como participante ativo do texto. Há também, neste sintagma, uma valorização da revista já que ela conseguiu fotos exclusivas que farão o leitor conseguir ver de perto. O sintagma "Aqui, este coágulo ameaça entupir a artéria" funciona como um aperitivo de outras fotos exclusivas em que veremos o coração funcionando. Os dêiticos aqui e este trabalham juntamente com o não-verbal de uma flecha apontando para o coágulo da foto. Os efeitos da foto são que o leitor tem acesso direto à esfera da ciência, uma vez que a foto foi tirada exclusivamente desta esfera e não da esfera da arte como a edição de março de 1995 em que há uma alusão a um quadro de Dali.

Portanto, a capa desta edição faz ver vozes de três discursos diferentes: o da ciência, o do jornalismo e o da ideologia do cotidiano. Este último, aliado ao uso do dêitico você, à expressão no fundo do coração e ao interesse que o assunto cirurgias cardíacas desperta, captam o leitor para a compra da revista.

O título do interior vale-se da primeira parte do título da capa "NO FUNDO DO CORAÇÃO” e situa-se na primeira página da reportagem ocupando toda sua metade superior. 


\subsubsection{Superinteressante - novembro de 1997}

A última edição deste segundo período possui o seguinte título na capa: "O CURATIVO GENÉTICO. A Medicina já começou sua maior revolução. Em breve, com um simples toque no DNA do paciente, ela será capaz de curar".

Pelo título percebemos que não se trata de algo que a ciência já descobriu e que terá efeitos práticos imediatos na vida das pessoas. Fala-se da previsão de, no futuro, as curas serem feitas geneticamente: "Em breve, com um simples toque no DNA do paciente, ela será capaz de curar". O ela deste período é uma anáfora que retoma dois referentes: ou ela se refere à Medicina ou à revolução. Entretanto, revolução engloba medicina, pois se trata de uma revolução da medicina. Assim, mesmo retomando revolução, quem será capaz de curar é a Medicina. Valoriza-se a ciência que, por meio de uma de suas áreas, a Medicina, é capaz de curar. Fala-se de uma área que está iniciando a sua maior revolução, por estar desvendando o código genético do ser humano.

Curar usado de forma intransitiva, cria a crença de que a Medicina genética será capaz de curar tudo: doenças, males, feridas, hábitos prejudiciais etc. Assim, o leitor vai querer ler a reportagem para saber como vai curar sua saúde no futuro.

O Band-Aid, famoso curativo de pequenos machucados na pele, faz as vezes de curativo dentro do gene para ilustrar não só a palavra curativo, presente no título, como também a própria ação de curar. Entretanto, sabemos que o Band-Aid facilita apenas a regeneração do tecido epitelial e não tem a menor função em outros tecidos de nosso organismo. Sua presença serve, ainda, para dialogar com o cotidiano do leitor, misturando-se na ilustração, duas ideologias, a da ciência e a da ideologia do cotidiano.

O sintagma "Em breve, com um simples toque no DNA do paciente" oferece a sensação ao leitor de tranqüilidade nas curas; no lugar de grandes cirurgias e bisturis, um simples toque no DNA.

É fascinante para o leitor a previsão que esta capa traz. É provável que um curioso, um apaixonado pela ciência e um preocupado com a sua saúde serão captados por esta capa. 


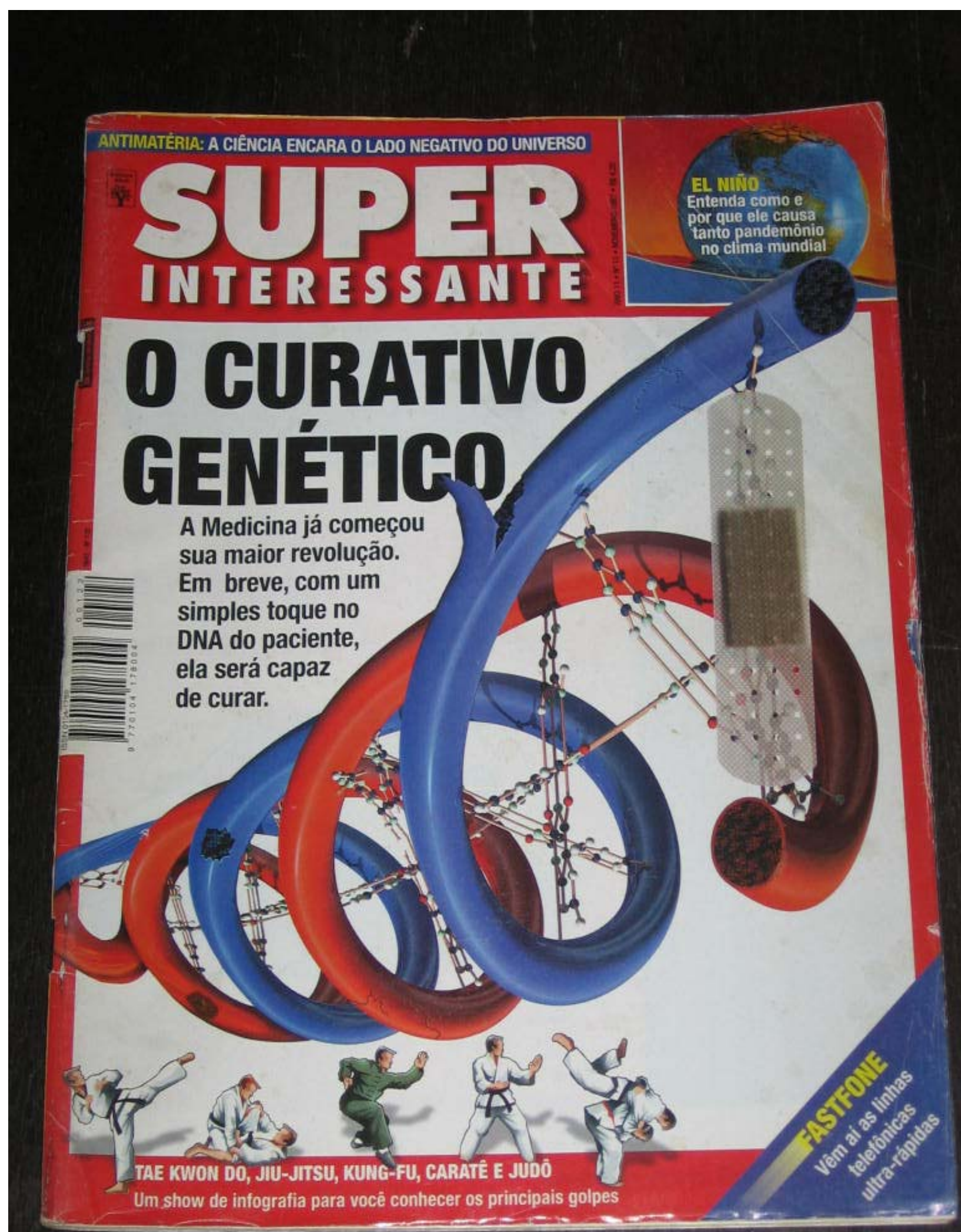


No interior da reportagem, encontramos o título "CURATIVOS GENÉTICOS” situado na parte superior da segunda página, seguindo a tendência de 2 das 6 reportagens analisadas deste período, de aproveitar, no título do interior, a parte que possui a maior fonte no título da capa ${ }^{35}$.

\subsubsection{Síntese dos títulos e imagens do segundo período}

As características dos títulos e imagens deste segundo período seguem abaixo sintetizadas:

1) duas presenças do dêitico você, sinalizando para um diálogo explícito com o leitor;

2) tendência de capa contendo não só informações a respeito do que será falado, mas sintagmas que causam surpresa e espanto, beirando ao sensacionalismo. Há muita diferença entre "DOR. ESTE TORMENTO PODE ACABAR" ou "MEDICINA CHINESA. CIÊNCIA DO EQUILÍBRIO" e "NA MIRA DO MOSQUITO ASSASSINO. Ele espalha a malária e mata 1,5 milhão de pessoas por ano. Agora, pesquisadores brasileiros lideram a corrida mundial pela vacina” ou "O CURATIVO GENÉTICO. A Medicina já começou sua maior revolução. Em breve, com um simples toque no DNA do paciente, ela será capaz de curar";

3) aumento considerável de informações nos títulos;

4) presença da ciência nacional, conferindo prestígio aos pesquisadores brasileiros;

5) presença de seqüências explicativas nas fotos ou ilustrações das capas, funcionando como um "aperitivo" da reportagem;

6) utilização de discursos de outras esferas para licenciar o discurso da esfera da ciência: "Tudo beleza", "Na mira do mosquito assassino", "No fundo do coração" (ideologia do cotidiano); "O veneno do bem" vinculado à ilustração de Eva, a serpente e a maçã (esfera da religião); alusão a um quadro de Salvador Dali na capa de março de 1995 (esfera da arte).

Passemos agora ao gerenciamento de vozes promovido pela voz da revista, por meio do discurso citado.

\footnotetext{
${ }^{35}$ Edição de abril/1997: título da capa $\rightarrow$ "O VENENO DO BEM. Cientistas brasileiros surpreendem o mundo com remédios de serpentes" e título do interior $\rightarrow$ "O VENENO DO BEM".

Edição de setembro/1997: título da capa $\rightarrow$ "NO FUNDO DO CORAÇÃO. Uma nova técnica brasileira revoluciona as cirurgias cardíacas" e título do interior $\rightarrow$ "NO FUNDO DO CORAÇÃO".
} 


\subsection{Análise dos discursos citados}

\subsubsection{Superinteressante - março de 1995}

Esta reportagem possui 12 páginas, 17 fotos, 14 ilustrações (das quais 10 são desenhos explicando como o oxigênio forma radicais livres). Há, ainda, 4 boxes (“As vitaminas roubadas no fogão de sua casa", "Linus Pauling, o precursor das superdoses", "As pistas fornecidas pelo sangue" e "A anemia também ameaça crianças bem alimentadas"). São 27 parágrafos que se dividem pelos seguintes sub-títulos: "Refeições podem não compensar as perdas do dia-a-dia" (par.1-7), "As carências são confundidas com sintomas de estresse” (par.8-13); "Única arma contra o ciclo vicioso dos radicais livres" (par.14-17), "Por que ouvir especialistas, antes de escolher sua vitamina” (par.18-24), “Quem não pode passar sem as megadoses” (par.25-27).

Em relação ao primeiro período, nota-se um acréscimo do número de páginas destinadas ao gênero reportagem de capa. O que não mudou foi a fragmentação da reportagem em várias partes, sinalizando para a forma composicional deste gênero que, ao articular desta maneira a reportagem, orienta o leitor nos sub-temas que são expostos, sem deixar que esses sub-temas não tenham ligação com o tema central que é o consumo de vitaminas.

Passemos ao discurso citado presente nesta edição:

\begin{tabular}{|c|c|}
\hline Tipos de Discurso & Reprodução \\
\hline $\begin{array}{l}\text { Discurso Direto } \\
\text { Preparado }\end{array}$ & $\begin{array}{l}\text { 1) O pior é que as refeições do nosso dia-a-dia já são desvitaminadas. "A comida pode } \\
\text { conter menos vitaminas do que prometem as tabelas nutricionais", afirma o engenheiro } \\
\text { de alimentos Cesar Romeu Araújo, da indústria farmacêutica Roche. "No Brasil, as } \\
\text { pessoas preferem uma farinha de trigo branquinha e ela é puro amido" (par.3). } \\
\text { 2) Desde a II Guerra Mundial, de olho na saúde de seus soldados, os Estados Unidos } \\
\text { passaram a devolver essas vitaminas perdidas à farinha, acrescentando-as depois da } \\
\text { refinação. Na década de 50, a maioria dos países europeus copiou a idéia. No Brasil, até } \\
\text { hoje, a farinha não é vitaminada. "Por causa disso, tivemos dificuldades", conta Regina } \\
\text { Helena Braga, da Interbakers, empresa que, desde 1988, produz pães para hambúrgueres } \\
\text { do McDonalds (par.4). } \\
\text { 3) A maior rede de fast-food do mundo anunciava que o seu sanduíche tinha a mesma } \\
\text { qualidade em qualquer parte do globo. E isso não era verdade, porque a farinha brasileira } \\
\text { era bem mais pobre que a de outros países. "Levamos dois anos até conseguir incluir o } \\
\text { complexo B na receita", diz Regina (par.5). } \\
\text { 4) Hoje, o pão de um Big Mac fornece mais de } 60 \% \text { das necessidades diárias desses } \\
\text { nutrientes. "Parece justo repor as perdas", diz a nutricionista Silvia Franciscato } \\
\text { Cozzolino, professora da Universidade de São Paulo. "Mas, em vez de biscoitos e } \\
\text { chocolates, os produtos vitaminados deveriam ser aqueles de grande consumo popular, } \\
\text { como o arroz e o açúcar" (par.5). } \\
\text { 5) Os fabricantes alegam que isso afetaria o preço para o consumidor. "O aumento seria } \\
\text { inferior a } 1 \% \text { nas gôndolas dos supermercados", garante Cesar Araújo, da Roche. } \\
\text { (par.6). } \\
\text { 6) A primeira conseqüência é a cegueira noturna: à noite, fica impossível enxergar } \\
\text { direito. Porque, para formar imagens com nitidez, é necessário um pigmento, fabricado } \\
\text { no fundo dos olhos, usando vitamina A como matéria-prima. Se a deficiência se } \\
\text { prolonga, a pessoa perde a visão. "O irônico é que, no Norte e no Nordeste, onde a }\end{array}$ \\
\hline
\end{tabular}


situação é mais grave, existem frutas típicas com alto teor dessa substância”, diz a nutricionista Eliete Salomar Tudisco, da Universidade Federal de São Paulo (ex-Escola Paulista de Medicina). "O jeito é ensinar as pessoas a procurar os alimentos certos" (par.8).

7) Nos Estados Unidos, onde as pessoas comem até demais - é o país com o maior índice de obesidade do mundo -, não se come direito. Em cada cem americanos, 35 têm falta de vitaminas. "Às vezes, os suplementos na forma de cápsulas são inevitáveis, como no caso de grávidas e pessoas sob regimes alimentares severos”, admite, cauteloso, Hélio Vanucchi, da Universidade de São Paulo, em Ribeirão Preto, interior do Estado (par.9).

8) Aliás, divididas em solúveis em água e solúveis em óleo, as vitaminas não são nada parecidas umas com as outras. $O$ único ponto em comum entre elas é que são fundamentais para o organismo em pequenas quantidades. "Há mais de cinqüenta delas, mas só treze são essenciais para o homem, ou pela sua importância ou pelo fato de seu corpo não conseguir produzi-las", explica Vanucchi (par.13).

9) Anarquistas do organismo, esses radicais reagem com tudo o que encontram pela frente para roubar um elétron. E a molécula roubada, então, também passa a ser um radical livre. "Só três substâncias podem quebrar essa cadeia destruidora", conta o médico ortomolecular paulista Wagner Fiori. "Elas são a vitamina $\mathrm{E}$, a vitamina $\mathrm{C}$ e o beta-caroteno, a matéria-prima da vitamina A" (par.14).

10) Por causa disso, os especialistas em Medicina Ortomolecular - área que trata da bioquímica do organismo humano - não se cansam de prescrever o trio. "De fato, vitaminas não são remédios. Mas seu uso contínuo pode evitar uma série de males", garante Fiori (par.15).

11) Esta idéia, que já provocou arrepios na comunidade científica, hoje encontra cada vez menos resistência. "Estão surgindo diversas evidências de que essas três vitaminas protegem contra enfartes", admite o médico Claude Lenfant, que dirige o Instituto Nacional do Coração, nos Estados Unidos. "Existe uma explicação: os radicais livres participam das reações que levam o colesterol a se acumular nas artérias” (par.15).

12) Quando o tema é nutrição, nada gera mais discussões do que as megadoses vitamínicas e seus efeitos contra doenças causadas pelos radicais livres. "Amanhã ou depois, pode ser que os benefícios dessas doses gigantes se confirmem", diz a nutricionista Sílvia Cozzolino, da USP. "Por enquanto, quem decide tomá-las está servindo de cobaia" (par.18).

13) O Suvimax, como está sendo chamado, começou há exatamente um ano, quando os cientistas passaram a escolher voluntários num grupo de 100000 indivíduos. "Pinçamos apenas 15000 deles, entre 35 e 60 anos de idade", explica o médico Serge Wecberg, em entrevista a SUPER (par.19).

14) É difícil comparar os benefícios de um nutriente em cidadãos que levam uma vida completamente diferente. "Se a gente dá vitamina para um executivo estressado, usando como base de comparação alguém que vive calmamente no campo, podemos chegar à conclusão distorcida de que tomar ou não tomar suplementos é indiferente", diz Wecberg (par.19).

15) Os consumidores não estão a fim de esperar todo esse tempo pela resposta. O mercado mundial de suplementos vitamínicos vem crescendo $8 \%$ ao ano - só nos Estados Unidos movimenta anualmente 4 bilhões de dólares. A mania gera alguns equívocos. "Sem ouvir um médico ou um nutricionista, pode-se engolir uma vitamina de que o organismo não está precisando e deixar de lado outra, que realmente está fazendo falta", alerta o professor Hélio Vanucchi, da USP (par.21).

16) Para os que compram vitaminas sem orientação, vale o alerta: o efeito de combinar diversos multivitamínicos por conta própria pode ser um tiro pela culatra. "Não adianta ingerir vitamina A, sem dispor de zinco no organismo", exemplifica a nutricionista Silvia Cozzolino (par.23).

17) Muitas vezes, o consumidor escolhe certo. Mas erra na marca e paga caro por isso. É quando compra aquela "vitamina natural", de preferência extraída de alguma fruta exótica, em vez de levar para casa uma versão sintética mais barata. "É uma bobagem", ensina Vanucchi. "Sintética ou natural, o corpo vai reagir àquela molécula como sendo 


\begin{tabular}{|c|c|}
\hline & $\begin{array}{l}\text { uma vitamina" (par.24). } \\
\text { 18) O Instituto Nacional do Saúde, nos Estados Unidos, revelou que o hábito de comer } \\
\text { vegetais ricos em vitamina C diminui } 13 \% \text { o risco de enfartes. Agora, esse bom hábito à } \\
\text { mesa somado a comprimidos da mesma vitamina faz a incidência despencar } 37 \% \text {. Não se } \\
\text { sabe a dose exata para se obter esse efeito preventivo. Mas a dúvida não apaga o fato: } \\
37 \% \text { menos chance de se morrer do coração. "O erro é achar que as pílulas substituem } \\
\text { um almoço", diz o nutrólogo Hélio Vanuchi. Nada substitui um prato cheio de gorduras, } \\
\text { carboidratos e proteínas (os únicos nutrientes que fornecem energia) (par.25). } \\
\text { 19) Mas até os cientistas mais ortodoxos, contrários às megadoses, admitem que os } \\
\text { suplementos são úteis em alguns casos. "Quem não precisa das megadoses por doenças } \\
\text { também deve avaliar a sua nutrição", diz o médico Wagner Fiori. "E, se for o caso, tomar } \\
\text { suplementos apenas para manter a dosagem normal" (par.26). }\end{array}$ \\
\hline $\begin{array}{c}\text { Discurso Indireto } \\
\text { Analisador de Conteúdo }\end{array}$ & 1) Há quem diga, porém, que essa luta pela boa dieta é inglória (par.9). \\
\hline $\begin{array}{c}\text { Discurso Indireto } \\
\text { Analisador de Conteúdo } \\
\text { (com modalizadores) }\end{array}$ & $\begin{array}{l}\text { 1) Para a Organização Mundial da Saúde, o Haiti é aqui, como no verso cantado por } \\
\text { Caetano Veloso e Gilberto Gil (par.8). } \\
\text { 2) A questão mais difícil, para o médico, é detectar quem está precisando de vitaminas } \\
\text { extras - na maioria das vezes, é quem nem dá bola pro assunto (par.11). }\end{array}$ \\
\hline $\begin{array}{l}\text { Discurso Direto } \\
\text { Substituído }\end{array}$ & $\begin{array}{l}\text { 1) Será que os alimentos não são mais os mesmos que forneciam aos nossos avós tudo o } \\
\text { que eles precisavam para viver?Não, não são (par.2). } \\
\text { 2) Mas como será que ficam as pessoas com saúde normal, que confiam no almoço } \\
\text { apressado do dia-a-dia? Elas também deveriam apelar para suplementos? "O melhor } \\
\text { caminho é corrigir a dieta", defende Vanucchi. "Se isso for impossível, as cápsulas } \\
\text { sempre serão uma opção" (par.10). }\end{array}$ \\
\hline
\end{tabular}

Como se vê, há, nesta reportagem, várias ocorrências de discurso direto preparado (19), um aumento considerável em relação ao período anterior. Esse fato pode apontar para algumas considerações. Em primeiro lugar, a Superinteressante inserida na esfera do jornalismo comercial, mostra, por meio de vários discursos citados por vários e diferentes especialistas, o serviço que ela fez: ela investigou, pesquisou, procurou saber, entrevistou vários especialistas que pudessem falar de vitaminas. Diferentemente do primeiro período, há aqui uma quantidade maior de especialistas, todos devidamente caracterizados por sua instituição de origem. $\mathrm{O}$ efeito de sentido que essa vasta pesquisa tem é que o leitor se sente informado pelos melhores especialistas e não apenas por um. Além disso, cria-se o efeito da verdade já que vários especialistas estão dizendo a mesma coisa.

Os verbos de elocução vão desde aqueles que não carregam condicionamento de interpretação como dizer, até aqueles que nos orientam para determinadas conclusões como admitir, defender. Admitir traz em sua acepção aceitar ou reconhecer algo que antes não era aceito ou reconhecido. Já defender, neste caso, significa sustentar uma opinião com argumentos e razões. Há, ainda, aqueles que nos levam à conclusão de que os cientistas têm um saber a mais que o leitor e, portanto, podem explicar, exemplificar, alertar, ensinar, garantir. 
A grande quantidade de discurso citado em forma de discurso direto fez com que a reportagem "quebrasse" alguns desses discursos da seguinte forma: primeiramente, expõe-se a fala do especialista; em seguida, o contexto narrativo encarrega-se de informar seu nome, sua especialidade e seu lugar de origem, para que se legitimem suas falas; finalmente, há uma continuação da fala do mesmo especialista, cortada por sua apresentação. Essa quebra facilita a leitura, não deixa o leitor cansado de ouvir a mesma voz.

Além disso, é importante notar que esses são, pela tipologia de Bakhtin/Voloshinov, discursos diretos preparados, aqueles que antecipam o conteúdo temático que será proferido pelos especialistas. Isto pode ser comprovado por essas quebras nos discursos para a apresentação do autor, pela utilização de anáforas, como, por exemplo, “dessa substância”, "mais de cinqüenta delas", "essa cadeia" etc.

Aliás, divididas em solúveis em água e solúveis em óleo, as vitaminas não são nada parecidas umas com as outras. O único ponto em comum entre elas é que são fundamentais para o organismo em pequenas quantidades. "Há mais de cinqüenta delas, mas só treze são essenciais para o homem, ou pela sua importância ou pelo fato de seu corpo não conseguir produzi-las", explica Vanucchi (par.13).

As anáforas acabam mostrando o diálogo existente entre contexto narrativo e discurso citado.

As três ocorrências de discurso indireto analisador de conteúdo, sendo duas delas com modalizadores, têm como autor uma instituição, um médico e o pronome interrogativo quem que, pelo contexto, refere-se às pessoas em geral. Isso contraria a tendência do primeiro período em que para se citar o discurso de outras esferas que não a ciência, utilizava-se o discurso indireto analisador da expressão, aqui, há o discurso indireto analisador do conteúdo para dar voz à ideologia do cotidiano:

Há quem diga, porém, que essa luta pela boa dieta é inglória.

Um exemplo interessante, em que duas vozes de diferentes esferas convivem no mesmo enunciado, é o seguinte:

Para a Organização Mundial da Saúde, o Haiti é aqui, como no verso cantado por Caetano Veloso e Gilberto Gil.

Embora haja um distanciamento em relação à fala desta instituição, marcado pelo uso do discurso indireto analisador do conteúdo com a utilização de modalizador, não há como não perceber que "o Haiti é aqui” não foi proferido pela OMS. Trata-se de um verso facilmente memorizável de uma canção de Caetano Veloso e Gilberto Gil que é utilizado aqui para resumir o conteúdo da fala da Instituição. No mesmo enunciado, uma mesma fala é atribuída a uma 
instituição internacional e a dois compositores nacionais, misturando-se a esfera da ciência e a esfera da arte. Por não se tratar de uma arte erudita, os versos parecem pertencer mais à ideologia do cotidiano o que acaba dialogando mais fortemente com o leitor. Ao criar esse enunciado, a revista está não só citando um discurso de uma instituição internacional, mas, ao mesmo tempo, está presumindo um conhecimento que o leitor tem. A preocupação com os enunciados já conhecidos do leitor articula-se ao tipo de relação da revista com o leitor, isto é, a revista quer construir sua reportagem de modo que o leitor a compreenda e possa ter uma "ativa posição responsiva" em relação a ela, no caso, seguir o conselho da revista de passar a tomar vitaminas.

Já nas duas ocorrências de discurso direto substituído, misturam-se as vozes do jornalista e do leitor. São perguntas que a revista faz como se fossem dúvidas que poderiam surgir no leitor. Ora a própria revista redime esta dúvida (exemplo 1), ora ela cita, em forma de discurso direto, um cientista para fazê-lo (exemplo 2).

\subsubsection{Superinteressante - agosto de 1995}

Nesta reportagem de 8 páginas, há 18 parágrafos divididos pelos seguintes sub-títulos: “A volta de um uso que já foi admitido" (par.1-7), "Governo Brasileiro pode liberar o THC” (par.814), "O cânhamo é utilizado em produtos" (par.15-18). Aparecem, ainda, 6 boxes (“As maiores virtudes e algumas promessas para o futuro", "Uma situação polêmica nos Estados Unidos", "Do cigarro até o cérebro em menos de 10 segundos", "A sensibilidade do usuário fica alterada", "A droga que virou tênis, papel, xampu e muito mais", "Do centro da Ásia para a América em 5000 anos"). Sete desenhos, um gráfico, um mapa e cinco fotos ilustram a reportagem. Novamente aqui, a articulação composicional aponta para a imagem que a revista faz do leitor: ao longo do processo da leitura, ele se organizará no rumo que o assunto está tomando. A reportagem não começa imediatamente com um discurso citado de cientista, mas há, antes, um "aquecimento" por meio de discursos de outras esferas, como vimos nas reportagens anteriores.

Esta edição trata de um tema polêmico, uma vez que sugere que algo ilícito, a maconha, pode fazer o bem. De um lado, o governo a proíbe, de outro, cientistas querem liberá-la para pesquisas e usos terapêuticos. Vejamos por meio do discurso citado, se a reportagem colocará as diferentes visões e vozes para este fato:

Tipos de Discurso

Discurso Direto

Preparado

\section{Reprodução}

1) Na verdade, a sua história é quase tão antiga quanto a civilização: há seis mil anos, aparecem no mais antigo texto medicinal conhecido, o Pen Ts'oo Ching, chinês, 


\begin{tabular}{|c|c|}
\hline & $\begin{array}{l}\text { sugestões de uso da planta. Ela era indicada para problemas como asma, cólicas } \\
\text { menstruais e inflamaçães da pele. E assim foi até recentemente, afirma o bioquímico } \\
\text { John Morgan, da Universidade de Cidade de Nova York. "Nos Estados Unidos, a asma, a } \\
\text { dor e os estresse foram combatidos com chás e outros preparados de maconha (mas não } \\
\text { cigarros) comercializados por grandes empresas, como Parke Davis, Eli Lilly e Squibb" } \\
\text { (par.2). } \\
\text { 2) Um exemplo, no caso do câncer, é a substância odonsetron, muito receitada. Em } \\
\text { comparação, o Marinol tem eficiência apenas moderada, diz o oncologista brasileiro } \\
\text { Sérgio Simon (par.6). } \\
\text { 3) Com tudo isso, quem resumiu bem a questão foi o professor de Farmacologia Roberto } \\
\text { Frussa Filho, da Universidade Federal Paulista/Escola Paulista de Medicina. "A maconha } \\
\text { funciona", disse ele à SUPER. "O que precisamos é avaliar se e quando vale a pena se } \\
\text { tornar uma op̧ãao para quem não aceita o tratamento convencional" (par.7). } \\
\text { 4) As autorizações, até certo ponto, contornavam o problema da ilegalidade. Que são } \\
\text { muitos, como lembra o brasileiro André Vilela Lomar, infectologista do Hospital Albert } \\
\text { Einstein, de São Paulo (par.9). } \\
\text { 5) Ele explica a situação em que estão os pacientes de Aids que aceitam bem o cigarro de } \\
\text { maconha como estimulante de apetite: "Apesar disso, não recomendo. Justamente porque } \\
\text { a maconha é ilícita, não se pode ter controle sobre a sua procedência, saber se está } \\
\text { misturada a um mato ou se contém algum fungo" (par.9). } \\
\text { 6) Na prática, porém, ainda há muito o que conhecer. Os próprios efeitos da maconha } \\
\text { ainda são incertos e podem ser contraditórios, como explica o farmacologista Isaltino } \\
\text { Marcelo Conceição, do Instituto Butantã. "O THC é um depressor, mas quando a } \\
\text { maconha é consumida em grupo costuma trazer euforia" (par.13). } \\
\text { 7) Feito de cânhamo, a fibra que se encontra no caule e nos galhos mais robustos da } \\
\text { planta de maconha, o Chronic tem um ínfimo teor de THC. "Estamos vendendo um } \\
\text { conceito ecológico", diz Marta Maddalena, gerente de produto da Adidas do Brasil, que } \\
\text { vai importar o calçado. "Essa fibra não passa por processos químicos, não danifica o } \\
\text { meio ambiente e tem uma cara rústica. É como o arroz integral" (par.16). }\end{array}$ \\
\hline $\begin{array}{c}\text { Discurso Indireto } \\
\text { Analisador de Conteúdo }\end{array}$ & $\begin{array}{l}\text { 1) E a ilegalidade da maconha natural - para fumar - é um problema, porque grande } \\
\text { número de médicos acha que ela é bem mais eficiente que a sua irmã artificial (par.5). } \\
\text { 2) Daí que na mais abrangente pesquisa americana, feita pela Universidade Harvard em } \\
\text { 1991, 70\% dos cancerologistas perguntados responderam que recomendariam o uso da } \\
\text { erva natural se esta fosse legalizada (par.4). } \\
\text { 3) Quase metade ( } 40 \% \text { ) disse que o aconselhava, mesmo sendo ilegal (par.4). }\end{array}$ \\
\hline $\begin{array}{c}\text { Discurso Indireto } \\
\text { Analisador de Conteúdo } \\
\text { (com modalizadores) }\end{array}$ & $\begin{array}{l}\text { 1) De acordo com o farmacologista Elisaldo Carlini, secretário nacional da Vigilância } \\
\text { Sanitária, está sendo avaliada pelo Ministério da Saúde a possibilidade de liberar o suo } \\
\text { do remédio (par.10). } \\
\text { 2) De acordo com o farmacologista Frussa Filho, é difícil comprovar os efeitos porque } \\
\text { os estudos clínicos - nos quais se acompanha de perto o comportamento de um usuário - } \\
\text { ainda são muito poucos (par.13). }\end{array}$ \\
\hline $\begin{array}{l}\text { Discurso Direto } \\
\text { Substituído }\end{array}$ & $\begin{array}{l}\text { 1) Por último, o entrave que parece ser o dilema decisivo atualmente: o da ilegalidade da } \\
\text { droga. Como separar a maconha que pode curar daquela que está misturada às mazelas } \\
\text { sociais do vício e do tráfico? Quando for possível dar uma resposta a essa questão, vai } \\
\text { ficar mais fácil conhecer melhor as suas virtudes e os seus defeitos (par.14). }\end{array}$ \\
\hline
\end{tabular}

Das 7 ocorrências de discurso direto preparado, cujo efeito é a objetividade por remeter às próprias palavras dos autores, 3 possuem dizer como verbo de elocução, não trazendo nenhuma orientação na interpretação; 2 possuem o verbo explicar que, como vimos nas análises das reportagens anteriores, gera o efeito de sentido de maior domínio de um saber por parte daquele que fala; 1 ocorrência do verbo afirmar que gera o efeito de sentido de credibilidade e 
poder para falar sobre determinado assunto; e, por fim, uma ocorrência de lembrar cujo efeito de sentido no contexto é dar uma informação a mais para o leitor.

Todos os indivíduos a quem esses discursos citados foram atribuídos são cientistas, contrariando a hipótese inicial de que esta reportagem, por tratar de assunto polêmico, fosse dar a ver outras vozes, não só as da esfera da ciência. De fato, opiniões divergentes são emitidas, mas todas provêm da esfera da ciência. Ora citam-se cientistas que são a favor da liberação da maconha para uso terapêutico, ora citam-se aqueles que vêem a maconha como uma droga ilícita e que, portanto, não deve ser consumida nem mesmo como remédio:

A favor:

- E a ilegalidade da maconha natural - para fumar - é um problema, porque grande número de médicos acha que ela é bem mais eficiente que a sua irmã artificial (par.5).

- De acordo com o farmacologista Elisaldo Carlini, secretário nacional da Vigilância Sanitária, está sendo avaliada pelo Ministério da Saúde a possibilidade de liberar o suo do remédio (par.10).

- Com tudo isso, quem resumiu bem a questão foi o professor de Farmacologia Roberto Frussa Filho, da Universidade Federal Paulista/Escola Paulista de Medicina. "A maconha funciona", disse ele à SUPER. "O que precisamos é avaliar se e quando vale a pena se tornar uma opção para quem não aceita o tratamento convencional" (par.7).

- As autorizações, até certo ponto, contornavam o problema da ilegalidade. Que são muitos, como lembra o brasileiro André Vilela Lomar, infectologista do Hospital Albert Einstein, de São Paulo (par.9).

\section{Contra:}

- Ele explica a situação em que estão os pacientes de Aids que aceitam bem o cigarro de maconha como estimulante de apetite: "Apesar disso, não recomendo. Justamente porque a maconha é ilícita, não se pode ter controle sobre a sua procedência, saber se está misturada a um mato ou se contém algum fungo" (par.9).

- Na prática, porém, ainda há muito o que conhecer. Os próprios efeitos da maconha ainda são incertos e podem ser contraditórios, como explica o farmacologista Isaltino Marcelo Conceição, do Instituto Butantã. "O THC é um depressor, mas quando a maconha é consumida em grupo costuma trazer euforia" (par.13).

Há, na reportagem, um gráfico que mostra esse conflito na comunidade científica, acompanhado do seguinte texto:

“... e divisão entre os médicos. Na mais abrangente pesquisa já feita entre cancerologistas, em 1991, 60\% disseram não recomendar o uso ilegal da maconha e $40 \%$ disseram aconselhar. Se ela fosse permitida, $70 \%$ recomendaria”.

Uma novidade que aparece nesta reportagem é que, em dois exemplos de ocorrência de discurso direto preparado (os exemplos 2 e 4), não aparecem as aspas para limitar as fronteiras entre o contexto narrativo e o discurso citado. Não podemos, entretanto, falar em discurso direto substituído nesses exemplos, uma vez que logo em seguida aparece um verbo de elocução e o autor do discurso:

Um exemplo, no caso do câncer, é a substância odonsetron, muito receitada. Em comparação, o Marinol tem eficiência apenas moderada, diz o oncologista brasileiro Sérgio Simon (par.6). 
Nas três ocorrências de discurso indireto analisador de conteúdo, os autores dos discursos citados são um grupo de médicos e especialistas, o que aponta para uma síntese da comunidade científica em relação ao conteúdo semântico desses discursos. Com o uso de modalizadores, as falas dos autores citados distanciam-se do contexto narrativo.

Como a voz da esfera da política não aparece para explicar o porquê da não liberação da maconha para fins terapêuticos, a reportagem se vale de um discurso direto substituído cuja pergunta, que poderia ser atribuída a todos os envolvidos (jornalistas, leitores, políticos e cientistas) fica sem resposta:

Por último, o entrave que parece ser o dilema decisivo atualmente: o da ilegalidade da droga. Como separar a maconha que pode curar daquela que está misturada às mazelas sociais do vício e do tráfico? Quando for possível dar uma resposta a essa questão, vai ficar mais fácil conhecer melhor as suas virtudes e os seus defeitos.

A voz da revista não atribui a ninguém a tarefa de dar essa resposta. Ela não diz "Quando for possível (a Ciência) dar uma resposta" ou "Quando for possível (a Política) dar uma resposta”. O que há nessa posição é um pronome vazio (Ø) que ainda não pode ser preenchido, mostrando que a discussão está longe de acabar.

Esta reportagem é diferente da primeira analisada que não cria dúvidas no leitor se ele deve ou não consumir vitaminas. Nesta reportagem, caso um médico receitasse o uso da substância da maconha ao leitor-paciente, este, após a leitura, certamente ficaria em dúvida, uma vez que a própria esfera da ciência não demonstrou uma visão única sobre o assunto. Os títulos analisados das duas edições anteciparam a certeza e a dúvida que viram em uma e outra reportagem.

\subsubsection{Superinteressante - janeiro de 1997}

Esta reportagem, que fala sobre a saúde da pele, possui 8 páginas e distribui-se em 8 parágrafos, 2 fotos, 14 ilustrações do interior da pele humana, 2 gráficos e 9 boxes ("Rosto liso e sem barba", "Com o passar do tempo", "Para a pele, todo dia é dia", "Uma relação clara", "O ataque dos raios", "Espremeção geral”, "Um belo crescimento", "As conquistas por um fio" e "A nova cara da maquiagem").

Os parágrafos estão dividido por uma introdução (par.1) e 3 sub-títulos: "Cápsulas com 1 milionésimo de milímetro" (par.2-3), "O Sol que, aos poucos, nos envelhece” (par.4-5) e "Para os cabelos, 40 horas de tortura" (par.6-8).

Em relação às outras reportagens analisadas, esta é a que contém menos parágrafos, porém, há bastantes boxes e ilustrações que dão ao leitor a oportunidade de visualizar o 
funcionamento da pele. Acompanhando essas ilustrações e também as fotos, há pequenas explicações científicas, como ocorre na capa da reportagem.

Como se vê, não são somente as falas dos cientistas que constroem a forma composicional deste gênero, mas também a fragmentação dos parágrafos, a presença de ilustrações, fotos, gráficos e boxes, orientando o leitor na assimilação do tema.

Os discursos citados presentes nesta reportagem seguem na tabela a seguir:

\begin{tabular}{|c|c|}
\hline Tipos de Discurso & Reprodução \\
\hline $\begin{array}{l}\text { Discurso Direto } \\
\text { seguido de síntese } \\
\text { do jornalista }\end{array}$ & $\begin{array}{l}\text { "Além de provocarem o câncer de pele, os raios solares são o principal fator de envelhecimento } \\
\text { cutâneo", garante a dermatologista paulista Shirlei Borelli. O sol que bronzeia a moçada nas } \\
\text { praias brasileiras ainda é mais cruel, porque aqui chegam mais raios ultravioleta A (UVA) do } \\
\text { que ultravioleta B (UVB) (par.4). }\end{array}$ \\
\hline $\begin{array}{l}\text { Discurso Direto } \\
\text { Preparado }\end{array}$ & $\begin{array}{l}\text { 1) Os cremes, porém, vão cada vez mais fundo dentro de seus limites. "Antes, eles eram sopões } \\
\text { de ingredientes sobre o rosto", reconhece Edith Clar, diretora de pesquisas da famosa marca } \\
\text { francesa Lancôme. "Eles mal penetravam } 0,2 \text { milímetro. Células tão superficiais já estão no } \\
\text { final do seu ciclo de vida e aí resta pouco a fazer" (par.3). } \\
\text { 2) Daqui pra frente, o certo é preferir os que também asseguram contra esse raios. "Ninguém } \\
\text { dava bola para os infravermelhos", explica Wilson Pinotti, diretor científico da Natura, uma das } \\
\text { líderes na fabricação de cosméticos no Brasil. "A gente achava que eles não faziam mal. Era um } \\
\text { engano." (par.5). } \\
\text { 3) Nos laboratórios da L'Óreal, na França, todo dia útil do ano } 450 \text { mechas de cabelos sofrem } \\
\text { em prol de mais progressos. Elas são bombardeadas por uma máquina que simula fortes banhos } \\
\text { de sol, chuvas e ventanias durante } 40 \text { horas seguidas. A cada } 15 \text { segundos, uma trégua. Ou } \\
\text { melhor, uma lavagem com xampus e cremes. "Não acaba por aí. Os fios seguem para um } \\
\text { extensômetro", conta Marie- Christine Auseau, uma das responsáveis pelo teste (par.6). } \\
\text { 4) Neste equipamento, são esticados até arrebentarem. É um jeito de aferir sua elasticidade. } \\
\text { "Antes, } 68 \% \text { dos fios tingidos se rompiam com um impacto de } 25 \text { gramas. Hoje, apenas } 10 \% \\
\text { deles se quebram com esse impacto", conta Marie-Christine (par.6). } \\
\text { 5) O segredo está em uma nova família de ingredientes incorporada aos xampus e, no ano } \\
\text { passado, às tinturas. "São polímeros que formam uma espécie de filme sobre cada fio", diz ela } \\
\text { (par.7). } \\
\text { 6) A Helena Rubinstein, indústria francesa, lançou no final do ano passado um creme com } \\
\text { vitamina C pura. Era o desafio de todos os fabricantes, pois essa substância, reconhecida como } \\
\text { a melhor forma de combater os desgastes diários, se desfaz com água e calor. "Conseguimos } \\
\text { conservar a polpa da laranja para ser injetada dentro cápsulas microscópicas de materiais } \\
\text { impermeáveis", conta Pierre Fodor, diretor de pesquisas da Helena Rubinstein (par.8). } \\
\text { 7) A tecnologia, ele confessa, veio da Rodhia, quando seu setor de remédios desenvolveu uma } \\
\text { vitamina concentrada para curar gripes e resfriados (par.8). }\end{array}$ \\
\hline
\end{tabular}

Apesar de haver uma ocorrência de discurso direto não preparado, o tema vem logo a seguir também desenvolvido pelo contexto narrativo:

"Além de provocarem o câncer de pele, os raios solares são o principal fator de envelhecimento cutâneo", garante a dermatologista paulista Shirlei Borelli. O sol que bronzeia a moçada nas praias brasileiras ainda é mais cruel, porque aqui chegam mais raios ultravioleta A (UVA) do que ultravioleta B (UVB).

Além disso, o sub-título, que é o que vem antes desse discurso citado, faz as vezes de antecipador do tema: "O Sol que, aos poucos, nos envelhece". 
Todas as outras ocorrências de discurso citado (7) aparecem sob a forma de discurso direto preparado, não aparecendo nenhuma outra forma de discurso citado.

Em relação aos verbos de elocução utilizados nestas ocorrências, temos, novamente, aqueles mais neutros que não nos levam a nenhum condicionamento de conclusão como diz e conta e aqueles mais carregados de significados como explica e garante que revelam aquela relação assimétrica: os cientistas têm um saber a mais que o leitor e, portanto, podem explicar e garantir algum fenômeno. Temos, ainda, a presença de reconhece que acaba revelando um diálogo com a história da ciência, uma vez que esse verbo de elocução aparece na fala de uma especialista que vai mostrar os avanços da ciência em relação aos cosméticos. $\mathrm{O}$ avanço tecnológico supera as descobertas do passado e a cientista reconhece isso. Ela reconhece não só os avanços como as desvantagens das descobertas anteriores. Esse reconhecimento, por parte de uma especialista, cria o efeito de sentido de que a ciência está sempre estudando e descobrindo coisas novas, sempre avançando, sempre pensando no futuro, além de transmitir a sensação de que a ciência não é uma área estagnada, ela reconhece os erros e avança, não fíca parada no tempo. As novas descobertas, aliás, são sempre melhores que as velhas. A voz da revista, ao enunciar tal reportagem, mostra que não quer ficar parada no tempo e que o leitor também não deve ficar.

Igualmente à edição anterior, nesta há uma ocorrência de discurso direto preparado sem o recurso das aspas (exemplo 7). Esse recurso leva o leitor a pensar que o conteúdo do enunciado pertence à revista quando, na verdade, trata-se de discurso de um cientista. As vozes da revista e da ciência, nesse caso, misturam-se e mostram-se igualmente confiáveis para o leitor.

\subsubsection{Superinteressante - abril de 1997}

Esta reportagem possui 8 páginas que contêm 3 boxes (“A solução na ponta dos dentes”, "Um século para chegar à farmácia" e "Rastejando nos laboratórios do mundo"), 12 ilustrações, 7 fotos e um mapa. São 14 parágrafos distribuídos da seguinte maneira: introdução (par.1-2), "Sai o ponto, entra a cola da cascavel" (par.3-7), "Cientistas copiam receita de jararaca" (par.8-13) e "Víbora malaia anima médicos canadenses" (par.14). Esta edição trata da possibilidade de venenos de alguns répteis como as jararacas, por exemplo, tornarem-se remédios para os seres humanos. Como a revista leva em conta que o leitor não poderá ainda responder a esse enunciado por meio de um fazer-fazer, uma vez que ainda trata-se de uma possibilidade, articula-se a 
reportagem sem a presença de muitos discursos citados, mas com bastantes seqüências narrativas que contam o processo das pesquisas que acabam deixando o leitor a par da situação. Há apenas duas ocorrências de discurso direto preparado e uma de discurso indireto analisador do conteúdo que exponho a seguir:

\begin{tabular}{|c|l|}
\hline Tipos de Discurso & \multicolumn{1}{c|}{ Reprodução } \\
\hline $\begin{array}{c}\text { Discurso Direto } \\
\text { Preparado }\end{array}$ & $\begin{array}{l}\text { 1)Primeiro, evita o risco de contágio por trocar o fibrinogênio do homem pelo do boi. } \\
\text { Depois, substitui a trombina do boi pela da cascavel. Os testes mostram que ela é até 500 } \\
\text { vezes mais eficaz na cicatrização, disse à SUPER a bióloga Izolete Thomazini, da equipe } \\
\text { de Botucatu (par.7). } \\
\text { 2)Foi preciso quase três décadas de trabalho para colocá-lo nas prateleiras das farmácias, } \\
\text { no final da década de 70. De lá para cá, muita investigação foi feita sem sucesso } \\
\text { definitivo, como lembra o professor Isaías Raw, diretor do Instituto Butantan. "O } \\
\text { captopril é o único exemplo acabado de uso do veneno para fins terapêuticos", disse ele } \\
\text { à SUPER (par.14). }\end{array}$ \\
\hline $\begin{array}{c}\text { Discurso Indireto } \\
\text { Analisador de Conteúdo } \\
\text { com modalizadores }\end{array}$ & 1) Para a ciência, elas guardam produtos utilíssimos nas glândulas letais (par.1). \\
\hline
\end{tabular}

Ainda que haja poucas presenças de discurso citado, muitos enunciados possuem como sujeito alguém da esfera da ciência, mostrando que a revista pesquisou o tema por meio de cientistas para compor a reportagem, articulando-a ao tema que é ainda uma possibilidade, que não tem como oferecer efeitos imediatos na vida do leitor. Daí a presença de seqüências narrativas que apenas iniciam uma modificação no comportamento do leitor:

1) Nos anos 60, o médico Sérgio Ferreira, atual presidente da Sociedade Brasileira para o Progresso da Ciência, descobriu na jararaca uma molécula que em 1977 virou remédio contra a hipertensão (par.2).

2) No ano passado, os cientistas anunciaram uma inovação sensacional: a de que o terrível veneno da cascavel, assim como o da jararaca, pode aumentar muito a eficiência das diversas colas de pele existentes. A partir disso, os brasileiros inventaram uma cola nacional. Que tem tudo para superar as concorrentes (par.5).

3) Desde 1989 os pesquisadores do Cevap, o Centro de Estudos de Venenos e Animais Peçonhentos, de Botucatu, notaram que ela acelerava muito o processo de regeneração do corpo (par.6).

4) O que ele fez foi isolar, em 1965, uma proteína do veneno da jararaca que, depois de muito trabalho, acabou se transformando em remédio para a pressão alta (par.9).

Os cientistas e pesquisadores aparecem também na posição de predicativo do sujeito ou agente da passiva, mostrando que, embora não estejam na posição de sujeito, são eles que agem, fazendo pesquisas e descobrindo novas maneiras de preservar a saúde. Enfim, são eles ainda que estão na fonte das informações.

1) Por isso mesmo é grande a expectativa levantada agora por uma equipe brasileira de Botucatu, no interior de São Paulo, dirigida pelo professor Benedito Barraviera, do Departamento de Doenças Tropicais da Universidade Estadual Paulista, a Unesp (par.4). 
2) Há dez anos essa trombina tinha sido separada dos outros ingredientes do veneno pelo professor Isaías Raw, atual diretor do Instituto Butantan de São Paulo (par.6).

3) O principal responsável pelo achado foi o médico Sérgio Ferreira, da Faculdade de Medicina de Ribeirão Preto, da USP, e atual presidente da Sociedade Brasileira para o Progresso da Ciência, a SBPC (par.8).

Feita desta maneira, sem a presença de muitos discursos citados, a reportagem acaba se tornando uma forma de contar a história da ciência, em particular, a história da obtenção de remédios a partir de venenos de alguns animais. Ela mostra para o leitor fatos que aconteceram nas pesquisas e como estão hoje em dia. Para isso, é necessário ir às fontes (os cientistas e pesquisadores) para poder escrever algo sobre o assunto. A revista mostra, lingüisticamente, a busca de informações que ela fez ao dizer que o pesquisador se remeteu diretamente à Super:

Primeiro, evita o risco de contágio por trocar o fibrinogênio do homem pelo do boi. Depois, substitui a trombina do boi pela da cascavel. Os testes mostram que ela é até 500 vezes mais eficaz na cicatrização, disse à SUPER a bióloga Izolete Thomazini, da equipe de Botucatu (par.7).

O efeito que essa remissão às fontes científicas gera é, assim como nos discursos citados, a credibilidade que o leitor vai ter ao ler a reportagem.

Seguindo uma tendência iniciada nas duas reportagens anteriores, também aqui não há o uso de aspas. Dessa forma, a leitura nos encaminha para a conclusão de que é a revista que fala e somente depois é que percebemos que as palavras são do cientista.

O verbo de elocução usado nas duas ocorrências de discurso direto preparado foi dizer, que não carrega nenhuma orientação na interpretação da fala.

Semelhantemente a todas as outras reportagens analisadas, o discurso indireto analisador do conteúdo com modalizadores foi a forma utilizada para citar um discurso em que se generaliza o autor:

Para a ciência, elas guardam produtos utilíssimos nas glândulas letais (par.1).

Confirmando a notoriedade que o título da capa oferece aos cientistas brasileiros, também a reportagem mostra os feitos de pesquisadores nacionais, reconhecidos, inclusive, no exterior:

1) Por isso, Ferreira chegou a ser cogitado pela Associação Brasileira de Hipertensão como um possível candidato ao Prêmio Nobel de Medicina do ano passado. Embora não tenha chegado lá, o médico brasileiro marcou um ponto notável na Medicina contemporânea. Tanto que a comunidade médica da Noruega institui recentemente um prêmio que tem o nome do cientista brasileiro (par.8/9). 
2) O mérito pela montagem da molécula sintética, em 1977, coube aos cientistas David Cushman e Miguel Ondetti, da empresa americana Squibb. Mas é claro que, sem o modelo biológico preparado pelo brasileiro, Cushman e Ondettti não teriam feito coisa nenhuma (par.13).

Construindo esses enunciados, a revista procura criar no leitor a concepção de que aqui no Brasil também se faz ciência de ponta e que, além disso, a ciência que aqui se vem fazendo é reconhecida no exterior. O leitor, a partir do estilo como esses enunciados foram construídos, tende a valorizar a ciência nacional, uma vez que o acento do enunciado é positivo em relação aos cientistas nacionais.

\subsubsection{Superinteressante - julho de 1997}

Esta reportagem é formada por 7 páginas, sendo as duas primeiras um grande mapa mundial que oferece um panorama geral mostrando em quais países a malária mais ataca. A reportagem conta ainda com 2 fotos, 24 ilustrações e 4 boxes ("A viagem destruidora do parasita", "A solução na ponta da agulha", "Quando o remédio engana o parasita" e "A lenta busca da cura”). Os 8 parágrafos que compõem a reportagem estão divididos por uma introdução (par.1-2) e pelos seguintes sub-títulos: “Aqui a malária persegue os garimpeiros” (par.3-4), “O Exército dos EUA derrotado pelo inseto" (par.5-6) e "Plasmódio muda de cara o tempo todo" (par.7-8).

Os discursos citados aparecem em todas essas partes da reportagem, apontando para o fato de que o leitor espera que todos os enunciados que mostrem a corrida pela cura sejam contados não só pelo jornalista como também pelo cientista.

Para discorrer sobre o momento em que a busca da cura dessa doença se encontrava em julho de 1997, a reportagem se vale dos seguintes discursos citados:

\begin{tabular}{|c|l|}
\hline $\begin{array}{c}\text { Tipo de } \\
\text { Discurso }\end{array}$ & \multicolumn{1}{|c|}{ Reprodução } \\
\hline $\begin{array}{c}\text { Discurso Direto } \\
\text { Preparado }\end{array}$ & $\begin{array}{l}\text { 1)De lá para cá, até surgiram remédios que salvam parte dos infectados. "Mas a malária ainda mata } \\
\text { entre 1,5 e 2,7 milhões de indivíduos por ano", lamenta o infectologista Aafje Rietveld, da } \\
\text { Organização Mundial da Saúde (par.2). } \\
\text { 2)Só no Amazonas é que a malária ainda cresce. "Aqui, o governo federal investe em agricultura", } \\
\text { explica Wilson Alecrim, diretor do Instituto de Medicina Tropical do Amazonas. "Os trabalhadores } \\
\text { vão para a floresta e ficam expostos", diz (par.3). } \\
\text { 3)Os resultados por enquanto são os melhores já registrados, mas só os testes poderão comprovar a } \\
\text { eficácia. "A dificuldade para se criar uma vacina é que o parasita está sempre se modificando", diz } \\
\text { Boulo, um felizardo que, em vinte anos de pesquisa de campo sobre a doença, não contraiu malária } \\
\text { nenhuma vez. "O plasmódio sabe mudar seu disfarce e se defender muito bem do sistema } \\
\text { imunológico dos seres humanos" (par.6). } \\
\text { 4)Foi o que aconteceu com a cloriquina, remédio desenvolvido pelo Exército americano durante a } \\
\text { Segunda Guerra Mundial. "A partir dos anos 60, já havia plasmódios resistentes à cloriquina na }\end{array}$ \\
\hline
\end{tabular}




\begin{tabular}{|c|l|}
\hline & $\begin{array}{l}\text { América do Sul", conta o parasitólogo brasileiro Luiz Hildebrando da Silva, que estudou a doença } \\
\text { durante } 33 \text { anos no Instituto Pasteur, na França, e está de volta ao Brasil desde março, para atuar na } \\
\text { Universidade de São Paulo (par.7). }\end{array}$ \\
\hline Discurso Direto & $\begin{array}{l}\text { 1) "O Exército americano perdeu a Guerra do Vietnã para a malária, e não para os vietnamitas", } \\
\text { afirma o infectologista Marcos Boulos, do Hospital das Clínicas de São Paulo e consultor do Centro } \\
\text { Rodhia de Doenças Tropicais (par.5). }\end{array}$ \\
\hline $\begin{array}{c}\text { Discurso Direto } \\
\text { Substituído }\end{array}$ & 1)O problema, portanto, não é remediar, é prevenir (par.2). \\
\hline
\end{tabular}

Em relação à presença de quatro discursos diretos preparados, pode-se dizer que não há nenhuma novidade em relação aos verbos de elocução (dizer, explicar, afirmar e contar), a não ser lamentar (exemplo 1) que mostra a dificuldade que é combater a malária. Embora se trate de discurso direto preparado, em que as fronteiras sintáticas entre o contexto narrativo e o discurso citado são bem definidas, este exemplo mostra uma total integração sintática entre os dois discursos, ligados pela conjunção adversativa mas:

De lá para cá, até surgiram remédios que salvam parte dos infectados. "Mas a malária ainda mata entre 1,5 e 2,7 milhões de indivíduos por ano", lamenta o infectologista Aafje Rietveld, da Organização Mundial da Saúde.

Isso mostra que, além de ter o sentido já antecipado pelo contexto narrativo, a sintaxe também é encaixada no discurso citado. A quebra de conclusão trazida pela conjunção mas ("Mas a malária ainda mata entre 1,5 e 2,7 milhões de indivíduos por ano") faz a revista usar o verbo de elocução lamentar, levando essa conclusão a ser um lamento não só do pesquisador, como também da voz da revista e do leitor.

Um discurso direto sem ter preparação ocorre também nesta reportagem. Não há elaboração antecipada do tema por parte do contexto narrativo; este passa diretamente a novidade do tema para a fala de um especialista, ainda que o sub-título "O Exército dos EUA derrotado pelo inseto", que é o que aparece imediatamente antes desse discurso citado, nos dê pistas daquilo que será falado:

"O Exército americano perdeu a Guerra do Vietnã para a malária, e não para os vietnamitas", afirma o infectologista Marcos Boulos, do Hospital das Clínicas de São Paulo e consultor do Centro Rodhia de Doenças Tropicais.

A presença de um discurso direto substituído serve para citar um ditado que poderia ser falado pelo leitor, pela revista ou pelos cientistas. A presença da conjunção coordenativa conclusiva portanto dentro dessa fala mostra que essa conclusão poderia pertencer a qualquer uma dessas vozes:

O problema, portanto, não é remediar, é prevenir. 
Igualmente a todas as reportagens anteriormente analisadas, mesmo as do primeiro período, a apresentação do cientista por meio do nome, da especialidade e da instituição na qual trabalha, é feita aqui:

Foi o que aconteceu com a cloriquina, remédio desenvolvido pelo Exército americano durante a Segunda Guerra Mundial. "A partir dos anos 60, já havia plasmódios resistentes à cloriquina na América do Sul”, conta o parasitólogo brasileiro Luiz Hildebrando da Silva, que estudou a doença durante 33 anos no Instituto Pasteur, na França, e está de volta ao Brasil desde março, para atuar na Universidade de São Paulo

No título da capa, vimos que ocorre uma valorização da ciência nacional. Também na reportagem ela é explicitada, contribuindo para a assimilação deste valor, já iniciada na reportagem anterior:

Por isso, a esperança hoje se concentra em uma nova vacina, criada pelos brasileiros Ruth e Victor Nussenzweing, da Universidade de Nova York (par.2).

Ainda que haja pesquisas para vacinas que combatam a malária, o fim da reportagem é desanimador, uma vez que coloca a doença como imbatível:

Novas drogas surgiram, algumas bem recentes, mas todas acabam caindo nas armadilhas do parasita. A indústria farmacêutica tem que buscar algo muito diferente, capaz de surpreender o inimigo. Só que o investimento para desenvolver um remédio desses é altíssimo e o lucro quase zero. Por isso as indústrias não se entusiasmam. E, passados 100 anos da descoberta de seu agente transmissor, a malária continua imbatível (par.8).

O fim da reportagem se alia à monstruosidade com que é colocado, na capa, o mosquito transmissor da malária.

\subsubsection{Superinteressante - setembro de 1997}

Esta reportagem possui 18 parágrafos, 24 ilustrações, 1 foto, 4 boxes ("Parado aí", “Agora, mexa-se!", "No meio do caminho tinha um coágulo" e "Dura realidade”), distribuídos em 8 páginas.

Os parágrafos se subdividem em uma introdução (par.1-2) e 3 sub-títulos: "O músculo é operado mas não perde o ritmo" (par.3-7), "O paciente se recupera mais rápido" (par.8-11) e "Uma gordura mais perigosa que o colesterol" (par.12-18). Esta divisão aponta para uma orientação nos sub-temas contidos na reportagem. Além disso, prepara-o para receber discursos provenientes do campo da ciência.

A grande novidade que esta reportagem traz, já anunciada no título da capa, é uma técnica cirúrgica inventada por um médico brasileiro, o Antonio Rivetti: nas operações para implantar 
pontes, o coração não vai mais precisar parar de bater. Essa é uma grande novidade, uma vez que lemos na reportagem que:

Cirurgiões cardíacos do mundo inteiro querem operar sem interromper os batimentos (par.6).

Este médico, portanto, é o autor de muitos dos discursos citados que aparecem. Entretanto, para mostrar como essa novidade foi recebida na comunidade científica, a revista dá voz a outros cientistas. Vejamos os discursos citados:

\begin{tabular}{|c|c|}
\hline $\begin{array}{l}\text { Tipo de } \\
\text { Discurso }\end{array}$ & Reprodução \\
\hline $\begin{array}{c}\text { Discurso } \\
\text { Direto } \\
\text { Preparado }\end{array}$ & 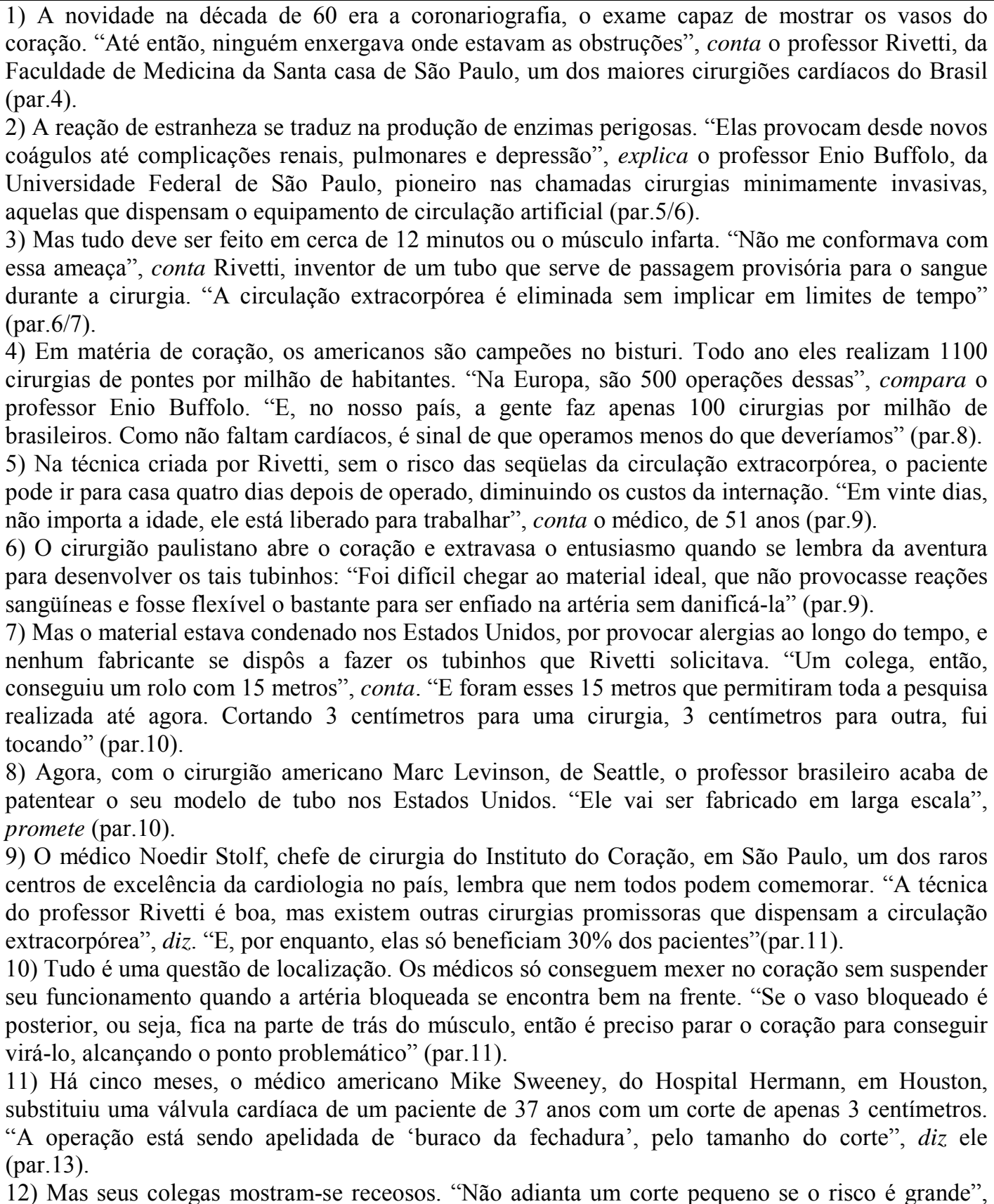 \\
\hline
\end{tabular}


comenta Enio Buffolo, em São Paulo (par.14).

13) Pesquisadores da Universidade de Harvard, nos Estados Unidos, acompanharam mais de 6000 cardíacos com colesterol moderado. Metade tomou o medicamento nos últimos dois anos, a outra metade, não. "O remédio fez baixar $44 \%$ a necessidade de pontes de safena em pacientes com mais de 65 anos", contou à SUPER o professor Frank Sacks, que conduziu a pesquisa. "Nos mais jovens, ainda não se sabe bem por quê, essa diminuição foi de apenas 19\%" (par.15).

14) O pior é que desde cedo o colesterol vai se acumulando nas artérias. No ano passado, o cardiologista carioca Carlos Scherr examinou 151 garotos entre 6 e 16 anos de quatro escolas do Rio de Janeiro. Um quarto deles tinha níveis de colesterol acima do normal. "Uma vez formadas, as placas não têm volta", lamenta o médico (par.16).

Esta reportagem é formada somente por discurso direto preparado, não ocorrendo nenhuma outra forma de se citar o discurso alheio.

Das 14 ocorrências de discurso direto preparado, 6 são atribuídas ao protagonista da reportagem, o médico Antônio Rivetti. Há uma fala de um médico americano mostrando a aceitação e a aplicação por parte dos estrangeiros da nova técnica do médico brasileiro (exemplo 11).

Entretanto, há falas que mostram o receio de muitos médicos com essa novidade (exemplos 9,10 e 12).

Essas falas geram uma polifonia na reportagem, uma vez que a revista deu vez a vozes diferentes do médico que revolucionou a cirurgia cardíaca por meio de uma técnica. A diferença é explicitada lingüisticamente pelo uso da conjunção adversativa mas que muda a conclusão de determinado fato, aparecendo ou na fala do cientista (9) ou na preparação do discurso citado (12).

Ao analisar os verbos de elocução utilizados nas falas dessas vozes dissidentes, vemos que há, basicamente, contar, dizer e comentar. Nenhum deles parece orientar a interpretação do leitor, de modo a levá-lo a ficar de um ou outro lado. No entanto, dentre as falas de Antonio Rivetti, temos o seguinte:

6) O cirurgião paulistano abre o coração e extravasa o entusiasmo quando se lembra da aventura para desenvolver os tais tubinhos: "Foi difícil chegar ao material ideal, que não provocasse reações sangüíneas e fosse flexível o bastante para ser enfiado na artéria sem danificá-la" (par.9).

8) Agora, com o cirurgião americano Marc Levinson, de Seattle, o professor brasileiro acaba de patentear o seu modelo de tubo nos Estados Unidos. "Ele vai ser fabricado em larga escala", promete (par.10).

Essas duas falas mostram claramente o entusiasmo de Rivetti que se contrapõe ao receio dos outros médicos. Rivetti, entretanto, está do lado de cirurgiões do mundo inteiro:

Cirurgiões cardíacos do mundo inteiro querem operar sem interromper os batimentos. A maioria dessa turma ousada isola com pinças a porção do vaso sangüíneo em que a ponte vai ser costurada (par.6). 
Logo, o entusiasmo com que é colocada a novidade é quebrado pela presença das falas (introduzidas pela conjunção mas) de médicos receosos.

Isso gera no leitor o sentimento da dúvida e da espera. A revista ainda tenta mostrar a prevenção como alternativa ao leitor:

Também existem novidades na área da prevenção. Foi comprovada a eficácia da pravastatina, a mais nova droga para baixar o colesterol (par.14).

Mas logo essa alternativa é abandonada em nome de falas que indicam a irreversibilidade do colesterol (exemplo 14).

Acresce-se a isto a descoberta de uma nova ameaça:

O coração jovem, aliás, sofre uma nova ameaça, a apolipoproteína, ou simplesmente Lp(a). Parecida com o chamado mau colesterol, ou LDl, essa gordura tende a entupir as artérias. [...] Tudo indica que os níveis dessa molécula sejam determinados pelos genes. [...]. Não adianta dietas, não existe remédios (par.17/18).

\subsubsection{Superinteressante - novembro de 1997}

Já sinalizada como uma promessa na capa, esta reportagem de 8 páginas constituídas de 17 parágrafos, 3 boxes ("Quatro alvos, quatro soluções”, "Táxis com endereço certo" e “Tramóias contra o mal”) e 19 ilustrações, não vem dar dicas de saúde ao leitor ou indicar a ele qual caminho seguir. Há somente uma exposição de uma área da medicina que, àquela época, estava iniciando suas pesquisas. É a terapia gênica, ou seja, a cura de doenças por meio de correções no DNA.

Os parágrafos da reportagem estão divididos em uma introdução (par.1-2) e em outros sub-títulos: "O remédio que vem de dentro das células" (par.3-6); "Quando os bandidos viram mocinhos" (par.7-12); "Um baque nas doenças hereditárias” (par.13-17). Ao articular essas partes com o discurso citado, a revista não só dialoga com as expectativas dele como também valida o tema por meio de discursos de cientistas.

Os discursos citados que aparecem na reportagem estão na tabela a seguir:

\begin{tabular}{|c|l|}
\hline Tipos de Discursos & \multicolumn{1}{|c|}{ Reprodução } \\
\hline Discurso Direto & 1) Nenhum dos testes deu resultado conclusivo, e seria uma falha ética imperdoável \\
Preparado & $\begin{array}{l}\text { exagerar as esperanças que eles criam para milhões de pacientes. "A nova terapia só deve } \\
\text { chegar aos hospitais na primeira década do próximo milênio", declarou à SUPER o } \\
\text { bioquímico Theodore Friedman, da Univesidade da Califórnia, o mais respeitado } \\
\text { especialista no assunto. "Mas, aí, as mudanças na Medicina vão ser fenomenais", disse o } \\
\text { cientista. "Comparáveis às das grandes revoluções do passado, como a das vacinas e a } \\
\text { dos antibióticos" (par.2). } \\
\text { 2) Na França, em julho passado, a SUPER ouviu do geneticista Georg Haase, } \\
\text { coordenador do trabalho, uma explicação completa sobre a participação dos ratos e dos } \\
\text { vírus em suas pesquisas. "Eles nos ajudaram a dar uma demonstração clara de que o mal } \\
\text { de Duchenne pode ser tratado por meio de um implante de genes", disse o cientista }\end{array}$ \\
\hline
\end{tabular}




\begin{tabular}{|c|l|}
\hline & (par.8). \\
3) Theodore Friedmann, atual diretor do Programa de Terapia Gênica da Universidade da \\
Califórnia, em Berkeley, usa as palavras como quem manipula um bisturi. Com precisão. \\
Foi desse modo que ele resumiu para a SUPER em que pé estão as tentativas atuais de \\
fazer reformas curativas nas moléculas de DNA. "Lemos às vezes na imprensa que a \\
terapia gênica já está pronta para virar rotina nos consultórios", diz ele. "Mas não está" \\
(par.13). \\
4) O trabalho avança um pouco às cegas. Mesmo assim, na opinião de Friedman, seria \\
um erro duvidar do imenso potencial da terapia gênica. "A despeito dos obstáculos, os \\
progressos estão acontecendo com rapidez cada vez maior" (par.15).
\end{tabular}

Seguindo a tendência de todas as outras reportagens do período, o discurso direto preparado é o tipo de discurso citado que prevalece. São cinco ocorrências de discurso direto preparado contra duas de discurso indireto analisador de conteúdo.

A começar pelos verbos de elocução, percebe-se que essa reportagem diferencia-se das demais por não utilizar contar e utilizar apenas uma vez dizer, verbos tão freqüentes nas outras. Nesta, além de dizer, temos declarar e completar. As ocorrências 2 e 3 foram as mais diferentes, que fugiram do padrão das demais.

Em 2, temos não só o valor de sabedoria que possui o pesquisador Georg Haase, por conseguir oferecer uma "explicação completa", como também o valor de credibilidade conferida à revista que foi atrás de fontes confiáveis, que pudessem dar essa "explicação completa": [...] a SUPER ouviu do geneticista Georg Haase [...]

Em 3, as palavras proferidas pelo pesquisador Theodore Friedmann, assemelham-se a operações precisas feitas com bisturi:

Theodore Friedmann [...] usa as palavras como quem manipula um bisturi. Com precisão. Foi desse modo que ele resumiu para a SUPER [...]

De acordo com esse discurso citado, não só confiamos nesse pesquisador porque ele é capaz de produzir um conhecimento como também é capaz de falar sobre ele. 
As duas ocorrências de discurso indireto analisador de conteúdo, tanto a que possui modalizador, quanto a que não possui, tratam as palavras do autor do discurso citado como diferentes às do contexto narrativo.

\subsubsection{Síntese do discurso citado no segundo período}

Vejamos as regularidades presentes neste segundo período, em relação ao discurso citado: 1) assim como no primeiro período, a forma predominante para dar voz ao discurso alheio foi o discurso direto preparado. Este fato aponta a preferência por este procedimento de transmissão de discurso citado para validar o tema sobre o qual discorre o contexto narrativo. A função é fazer o leitor acreditar que o que está sendo falado na reportagem tem fontes confiáveis, trata-se da voz de cientistas. $\mathrm{O}$ efeito de realidade dessas vozes é adquirido por meio do recurso das aspas, e por meio da apresentação do cientista (nome, sobrenome, especialidade, instituição de origem);

2) os verbos de elocução utilizados tanto no discurso direto preparado como no discurso indireto analisador do conteúdo avaliam, condicionam e antecipam a recepção da voz da ciência pelo leitor, embora a variação dos verbos vá diminuindo com o passar do tempo. Se na primeira reportagem do período foram registrados 8 diferentes verbos de elocução (dizer, admitir, defender, explicar, exemplificar, alertar, ensinar e garantir), na última só havia 3 (dizer, declarar e completar);

3) ausência de discurso indireto analisador da expressão. No primeiro período, esta foi a forma utilizada para dar voz aos discursos das outras esferas. Neste segundo período, quando isso ocorreu, a forma utilizada foi o discurso indireto analisador de conteúdo. Isto aponta para uma valorização das vozes das outras esferas que, ao aparecerem transmitidas por meio desse procedimento, ganham distância, respeito e o conteúdo acaba tendo mais atenção;

4) presença constante de discurso direto substituído em que, não se atribuindo um autor para esse discurso, generalizam-se as vozes. Trata-se de um enunciado que pode ser do leitor, do jornalista do cientista, ou de todos eles ao mesmo tempo. Estes enunciados estão sempre em forma de perguntas e as respostas vêm a seguir dadas pelo jornalista ou pelo cientista. Este tipo de discurso citado representa a simulação de um diálogo convencional, pertencente aos gêneros primários do discurso, o que comprova a afirmação de Bakhtin de que os gêneros secundários integram e reelaboram os gêneros primários; 
5) representação da SUPER como aquela que busca as fontes mais certas e confiáveis para falar sobre determinado assunto e que, portanto, tem informações exclusivas. Isso leva em conta o fundo aperceptível que possui o leitor dessa revista: ao comprá-la, ele acreditou que ela teria os conhecimentos de que ele precisava;

6) falta do recurso das aspas em algumas falas de discurso direto preparado, o que nos leva, primeiramente, para a interpretação de que o enunciado é da revista. No entanto, essa interpretação é quebrada quando se lê em seguida um verbo de elocução. Cogita-se, deste modo, uma outra variante de discurso citado não mencionada por Bakhtin/Voloshinov;

7) muitos dos discursos citados mostram o estado e o andamento em que as pesquisas se encontram, não garantindo ao leitor uma certeza acerca do assunto. Muitas das reportagens mostram assuntos que, àquela época, eram promissores, incertos ainda de seus êxitos. No entanto, os temas que apareceram nessas reportagens foram articulados de forma a que houvesse já uma "resposta antecipável": por meio dos discursos citados de cientistas, o leitor acredita que novas técnicas para cirurgias vingarão, bem como a cura pela genética etc.;

8) presença da polifonia em algumas reportagens (agosto de 1995 e setembro de 1997) gerando uma falta de segurança no leitor que, ao procurar uma informação precisa para cuidar de sua saúde, encontrará, no lugar, uma coleção de diferentes opiniões de cientistas;

9) valorização de cientistas nacionais, projetando-os no cenário da comunidade científica internacional;

10) a organização composicional da reportagem em várias partes, com aumento considerável de ilustrações. Ao se articularem com os discursos citados, essas partes ganham "ecos" de discursos científicos os quais, por sua vez, são considerados determinantes na assimilação do tema. Além disso, ao se articular em partes, a revista distribui as falas citadas de acordo com o sub-tema indicado pelos sub-títulos que todas as reportagens possuem, isto é, a articulação composicional está relacionada aos desdobramentos do tema. 
(6)

\section{Análise do terceiro período}

Do conjunto de reportagens analisadas, o terceiro período é aquele que se compõe dos anos de 2002 e 2003. Como se verá, este período travará um maior diálogo com o leitor por meio dos títulos e imagens das capas e, além disso, haverá uma mudança temática, o que implicará em uma nova postura diante da saúde por parte das esferas envolvidas na atividade da divulgação científica, a saber, a esfera da ciência, do jornalismo e, ainda, a ideologia do cotidiano.

\subsection{Análise dos títulos e imagens}

\subsubsection{Superinteressante - abril de 2002}

Esta edição tem como título: "DEVERÍAMOS PARAR DE COMER CARNE? Carne dá câncer? Dá para viver só de vegetais? Seu corpo foi feito para digerir carne? Saiba o que é fato e o que é lenda no debate sobre o vegetarianismo".

A começar pela quantidade de palavras, esta edição, em relação a todas as outras analisadas até o momento, é a que contém um maior número de informações. A presença de quatro perguntas no título (Deveríamos parar de comer carne?; Carne dá câncer?; Dá para viver só de vegetais? e Seu corpo foi feito para digerir carne?) remetem a perguntas que poderiam ser feitas pelo leitor. Temos aqui, portanto, discursos diretos substituídos, já que a revista torna-se cúmplice do leitor nas dúvidas que ele tem acerca do assunto e faz com que ele se sinta representado na estrutura lingüística. Essa cumplicidade é lingüisticamente marcada pelo uso da primeira pessoa do plural inclusivo (deveríamos), mostrando que a dúvida não é só do leitor, mas também do jornalista.

Logo após ter exposto as dúvidas tanto do leitor quanto da revista em forma de perguntas, a voz da revista exclui-se do conjunto de leitores ao enunciar "Saiba o que é fato e o que é lenda no debate sobre o vegetarianismo". Nesse enunciado, há uma distância explícita entre a revista, que detém informações exclusivas, e o leitor que é convidado a saber verdades sobre o assunto. 





O convite é explicitado por meio do verbo saber que, usado na forma imperativa, pode também ser lido como uma ordem.

A distância entre o conhecimento do leitor e as informações exclusivas da revista manifesta-se também pelo contraste entre as palavras fato e lenda. As respostas das perguntas em forma de discurso direto substituído podem ser fatos (esfera da ciência) ou lendas (ideologia do cotidiano). A palavra fato traz em si algo absoluto, verdadeiro, real, contra o qual não se pode lutar ou discordar. Remete às verdades indiscutíveis buscadas pelos cientistas ao analisar os fenômenos e às quais os jornalistas têm acesso. Já a palavra lenda refere-se ao plano das opiniões enraizadas na ideologia do cotidiano, mas que não possuem nenhuma comprovação. A revista, portanto, fará o serviço para o leitor de separar essas duas ordens de saberes.

A revista, ao enunciar esse tema, está pressupondo um leitor preocupado com as lendas sobre o consumo de carne, que vem ouvindo sobre os males que a carne pode causar e que, portanto, busca alternativas. A grande alternativa é parar de comer carne e passar a ingerir somente vegetais, tornando-se vegetariano. Além do título, a capa ${ }^{36}$ traz um indivíduo de terno cuja cabeça é formada por um pé de alface. A seriedade do terno e da gravata que o homem da capa está vestindo é quebrada por esse estranhamento na cabeça, o que gera uma ironia. Numa primeira leitura, temos um indivíduo passivo que, de tanto ouvir lendas sobre a carne, deixa de consumi-la e torna sua alimentação à base de vegetais. Um outro sentido da foto é o indivíduo radical, aquele que age espalhando as lendas e só tem esse assunto "na cabeça". Em ambos os casos, o indivíduo está tomado por esse assunto e até mesmo cego; deste modo, o papel da revista é clarear os fatos e as lendas, tornando o leitor bem informado.

Uma articulação entre os aspectos verbais e não-verbais que criam um forte contraste é a presença do pé alface com a projeção do sintagma "COMER CARNE" que possui a maior fonte e o maior destaque dentre todos os aspectos verbais. Essa articulação cria uma separação entre aqueles que comem carne e aqueles que não comem. Deste modo, muitos leitores se interessarão pela reportagem, uma vez que as pessoas, assim como os animais, podem ser divididos nesses dois grupos (os que comem carne e os que são vegetarianos) e, ainda, pode haver desdobramentos: aquele que se preocupa com o consumo de carne e quer virar vegetariano ou

\footnotetext{
${ }^{36}$ A foto da capa não é uma criação brasileira conforme explica a Superinteressante no índice da edição: "A capa desta edição foi inspirada na brilhante idéia da revista The New York Times Magazine, publicada em maio de 2001" (página 8).
} 
aquele que só consome vegetais, mas sente falta de carnes. Ao ler a reportagem, o indivíduo pode tirar suas dúvidas e decidir fazer parte de algum dos grupos. Do mesmo modo que na reportagem "GORDOS \& MAGROS. Quem é quem na balança", aqui também esta divisão entre os que comem carne e os vegetarianos parece abranger todos os tipos de leitores. A utilização de um rosto coberto, não identificando a pessoa também leva a uma generalização. Se fosse um artista famoso ou um médico na capa, a orientação da interpretação seria diferente, ou seja, o leitor iria primeiramente se identificar ou não com aquele rosto para, em seguida, identificar-se com a posição tomada diante da alimentação.

O título do interior da reportagem retoma a primeira pergunta do título da capa: “Deveríamos parar de comer carne?”. A estratégia de pergunta é mais uma vez aproveitada aqui, já que esta parece ser uma dúvida de toda a sociedade, pois, de acordo com o título, parece não haver ainda um consenso sobre o vegetarianismo. Ao se valer do recurso da pergunta, o leitor percebe que essa dúvida não é somente dele, outros compartilham dessa mesma insegurança em relação à alimentação.

\subsubsection{Superinteressante - agosto de 2002}

Esta reportagem traz um tema já discutido em uma das edições do segundo período: o uso da maconha. As capas, inclusive, são bastante parecidas, sendo a presença dos tubos de ensaio na reportagem do segundo período a única grande diferença. No mais, as duas são igualmente ilustradas com uma erva de maconha ocupando a maior parte da capa.

A parte verbal, do mesmo modo que a reportagem do segundo período e a primeira reportagem analisada neste período, é composta de perguntas: "MACONHA. Por que é proibida? O que aconteceria se fosse legalizada? Como a ciência aumentou seus efeitos? Faz mal à saúde?”. Como se vê, só há perguntas nesse título que são atribuídas tanto ao leitor quanto à revista. Isso nos faz considerar esses enunciados compostos por discursos diretos substituídos, já que várias vozes podem ser ouvidas. Trata-se de uma estratégia por parte da revista de se tornar cúmplice do leitor nas suas dúvidas sobre assunto, ou seja, o leitor não se sentirá o único a ter dúvidas.

Ao contrário do título anteriormente analisado, que convida o leitor a saber das respostas ("Saiba o que é verdade e o que é lenda no debate sobre o vegetarianismo"), esta não faz nenhum convite explícito ao leitor. Entretanto, as perguntas da capa acabam carregando, implicitamente, a idéia de que as respostas e o "saber" estão no interior da reportagem. 


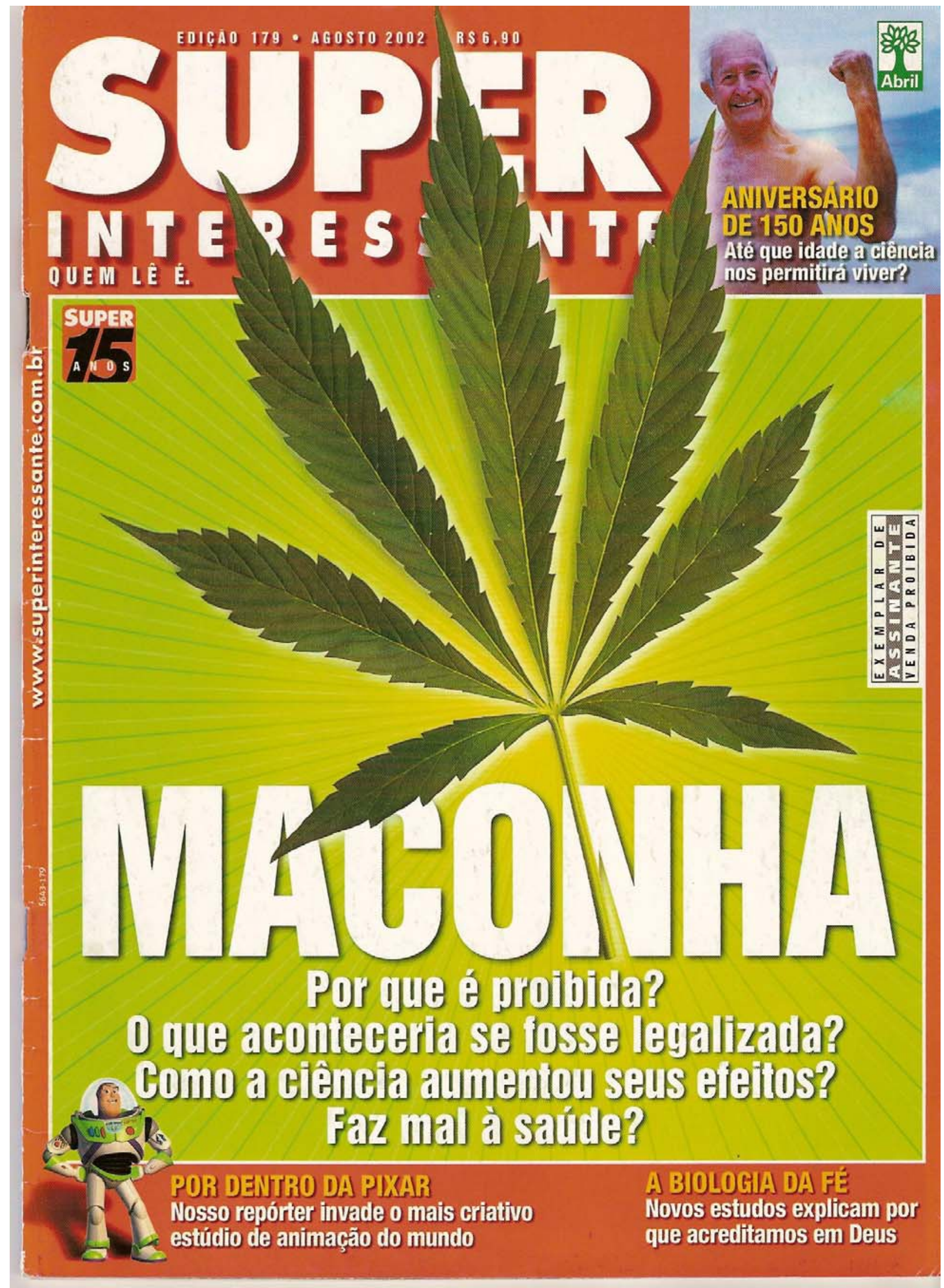


Há, neste título, perguntas que podem ser respondidas por diferentes esferas do conhecimento. A primeira, por exemplo, "Por que é proibida?", deve ser respondida não tanto pela ciência, mas pelo governo. As duas últimas, "Como a ciência aumentou seus efeitos?" e "Faz mal à saúde?", podem ser respondidas pela esfera da ciência. Já a segunda, “O que aconteceria se fosse legalizada?", pode ser respondida tanto por uma quanto por outra esfera, isto é, para o governo, se a maconha fosse legalizada, haveria certas conseqüências; para a ciência, outros tipos de conseqüências.

Nos dois primeiros enunciados em forma de pergunta, há a presença da voz passiva (é proibida e fosse legalizada) sem haver um agente explícito. Ao pressupor que o leitor saiba quem é o agente, a revista está trabalhando com o seu conhecimento de mundo. Apesar disso, o foco não é tanto o agente, mas a maconha, seu uso e seus efeitos.

O título do interior, que aparece na parte superior da primeira página da reportagem, usa uma palavra que tem quase o mesmo sentido de fato no título da edição anteriormente analisada: "A VERDADE SOBRE A MACONHA". Ao enunciar a palavra verdade, a revista está se remetendo à esfera científica, que busca as verdades dos fenômenos observados. Do mesmo modo que no título anterior, a revista promete separar a verdade das lendas, neste caso, as lendas em torno da maconha. Trata-se de um título ousado, já que visa a mostrar falas sobre verdades indiscutíveis a respeito da maconha, e não uma coleção de opiniões de diferentes especialistas acerca desse assunto.

\subsubsection{Superinteressante - setembro de 2002}

O título desta edição é, até o momento, o que mais se dirige explicitamente ao leitor: “DIABETE. TUDO O QUE VOCÊ PRECISA SABER PARA NÃO DESENVOLVER A SUA. Há 350 milhões de diabéticos no mundo. Metade ainda não sabe que está doente. Talvez você seja um deles". Como se vê, o título usa duas vezes o dêitico você e uma vez o pronome sua, que se remetem ao leitor.

O sintagma “TUDO O QUE VOCÊ PRECISA SABER PARA NÃO DESENVOLVER A SUA" traz, na forma de um enunciado que possui uma locução verbal como precisa saber, uma ordem ao leitor, em tom de recomendação: você precisa saber. A oração subordinada adverbial final justifica o objetivo da recomendação: para não desenvolver a sua (diabete). Essa oração 


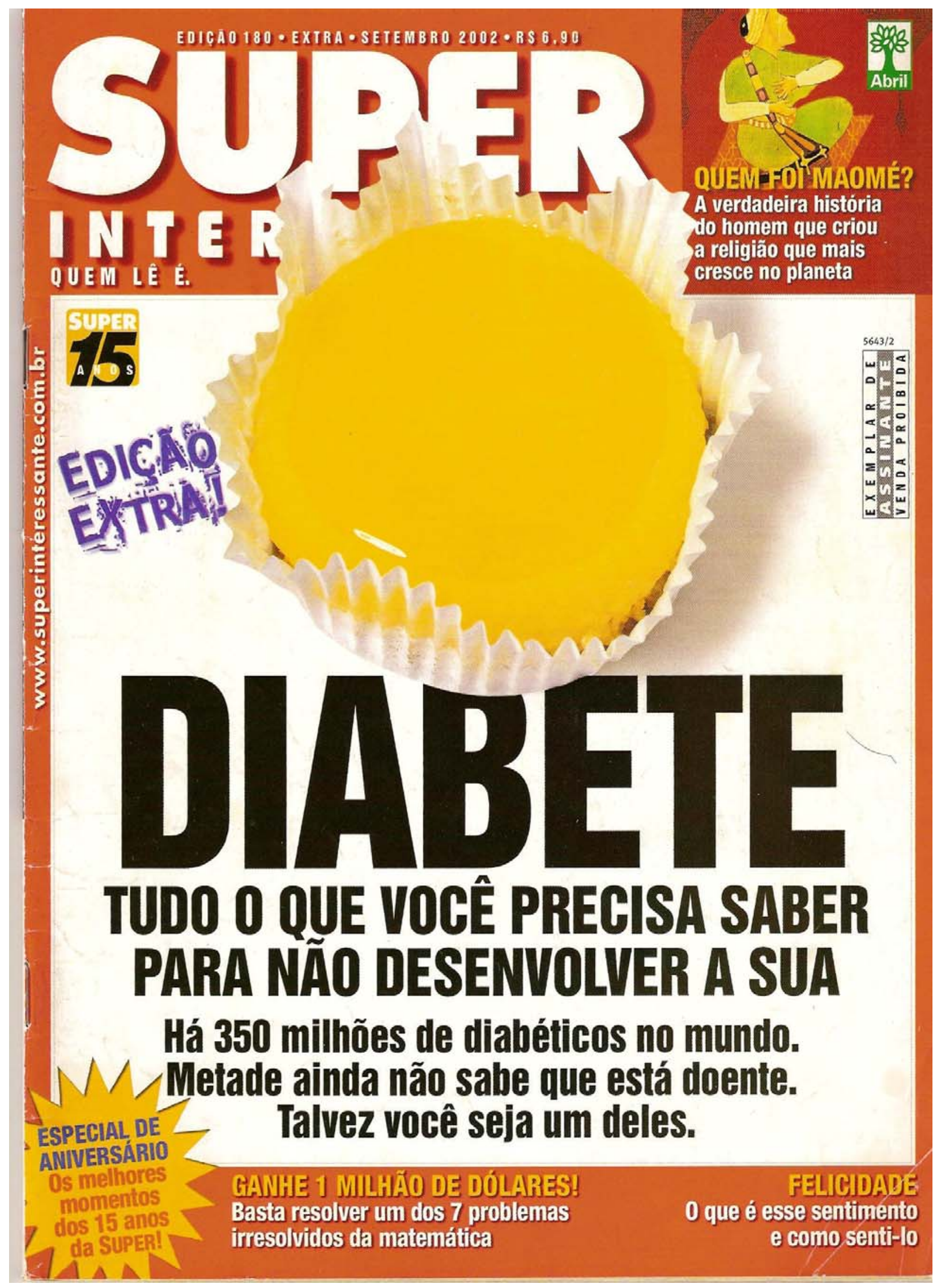


subordinada é um argumento que visa a convencer o leitor a cumprir a ordem de saber tudo sobre a diabete.

O uso do pronome tudo promete esgotar o assunto, redimir todas as dúvidas sobre a doença. Se o leitor efetuar a leitura da reportagem, ele estará pronto para enfrentar tal doença, curando-a ou prevenindo-a.

O comentário que vem logo abaixo trabalha com dados assustadores, semelhantemente ao que ocorre com os dados sobre o mosquito que causa a malária 37 : "Há 350 milhões de diabéticos no mundo. Metade ainda não sabe que está doente. Talvez você seja um deles”. O número é bastante alto, mas o que mais chama a atenção é o não-saber dos que possuem a doença. O verbo saber é trabalhado gerando os seguintes sentidos: ou você sabe lendo a revista (TUDO O QUE VOCÊ PRECISA SABER PARA NÃO DESENVOLVER A SUA) ou você permanece não sabendo, assim como metade de 350 milhões de pessoas ("Metade ainda não sabe que está doente"). O leitor prefere saber sobre a doença até por que a revista enuncia explicitamente, trabalhando com a ameaça: "Talvez você seja um deles". Esse comentário, portanto, faz um movimento que caminha do particular para o geral; em seguida, do geral para o particular: TUDO O QUE VOCÊ PRECISA SABER PARA NÃO DESENVOLVER A SUA $\rightarrow \mathbf{3 5 0}$ milhões de diabéticos no mundo $\rightarrow$ Talvez você seja um deles. No caminho, há a presença da doença, da falta de conhecimento, do medo.

Utilizando o advérbio de dúvida talvez, a revista não oferece nenhuma certeza ao leitor, entretanto, oferece tanto a dúvida ao leitor quanto a possibilidade de essa mesma dúvida se tornar uma certeza. Assim, o título passa de uma recomendação para uma ordem não explícita para que a revista não passe a imagem de autoritária, mas sim daquela que ajuda, que aconselha, que avisa e até mesmo salva.

A presença de um enorme quindim na capa, logo acima da palavra DIABETE que, por sua vez, possui a maior fonte, trabalha com os conhecimentos presumidos do leitor de que essa doença está associada à presença de açúcar no sangue. Além disso, esse doce é popular o que gera um diálogo das explicações científicas, anunciadas no título, com a ideologia do cotidiano. É também uma outra forma de captar o leitor, uma vez que muitos podem ficar com água na boca

\footnotetext{
37 "NA MIRA DO MOSQUITO ASSASSINO. Ele espalha a malária e mata 1,5 milhão de pessoas por ano. Agora, pesquisadores brasileiros lideram a corrida mundial pela vacina”. (Superinteressante - julho de 1997)
} 
ao ver esse grande quindim na capa. A cor preta utilizada nas letras causa um contraste com o fundo branco e com a cor amarela do doce.

O título do interior projeta a doença como o grande mal do século "DIABETE, O NOVO MAL DO SÉCULO” e se encontra na primeira página da reportagem, situando-se da metade para a parte inferior da página. Acima do título, há fotos de vários tipos de doces. Diferentemente do título da capa, este apenas caracteriza a diabete, apontando-a como uma doença bastante grave, o mal deste século. Aparentemente, não há nenhum diálogo explícito com o leitor, por meio de uso de dêiticos ou por meio do uso do imperativo. Trata-se de uma frase declarativa que, no entanto, por carregar consigo uma caracterização ruim com a qual o leitor não quer se identificar, também tem a intenção de influenciar para a leitura da reportagem.

\subsubsection{Superinteressante - novembro de 2002}

Nesta edição não há nenhuma pergunta em forma de discurso direto substituído. A semelhança com os demais títulos do período é a quantidade de informações: "A CIÊNCIA DE SER SAUDÁVEL. Novos estudos mostram que ter saúde é mais fácil e barato do que você imagina. Saiba por que cada vez mais pessoas estão trocando os remédios por: • Alimentos que evitam doenças; • Exercícios que estimulam a cura; • Atividades que prolongam a vida”.

O sintagma "A CIÊNCIA DE SER SAUDÁVEL" é o que possui a maior fonte, sendo a parte "DE SER SAUDÁVEL" ainda maior e a única em que aparece a cor verde. As demais letras estão em preto. A cor verde desse sintagma combina com a cor da pêra que a mulher de olhos esverdeados segura na foto da capa. A mulher da foto apresenta uma pele saudável e, ao segurar uma pêra, revela também hábitos saudáveis. Diferentemente da foto da mulher da edição de janeiro de 1997, em que o rosto não aparentava nenhuma expressão, era um "rosto científico", o desta edição traz um sorriso, o que acaba aproximando o leitor, já que se trata mais de um "rosto da ideologia do cotidiano".

Além do aumento de informações na parte verbal, houve também uma mudança temática, já sinalizada no título da edição anterior. Se nos títulos do primeiro e segundo períodos o tema era a cura de doenças, a importância das descobertas da medicina em nossas vidas, agora há o 
tema da prevenção de doenças e manutenção da saúde. Pode-se dizer que, aqui, temos palavras que possuem um traço semântico positivo como ser saudável, fácil, barato, além de evitar, 


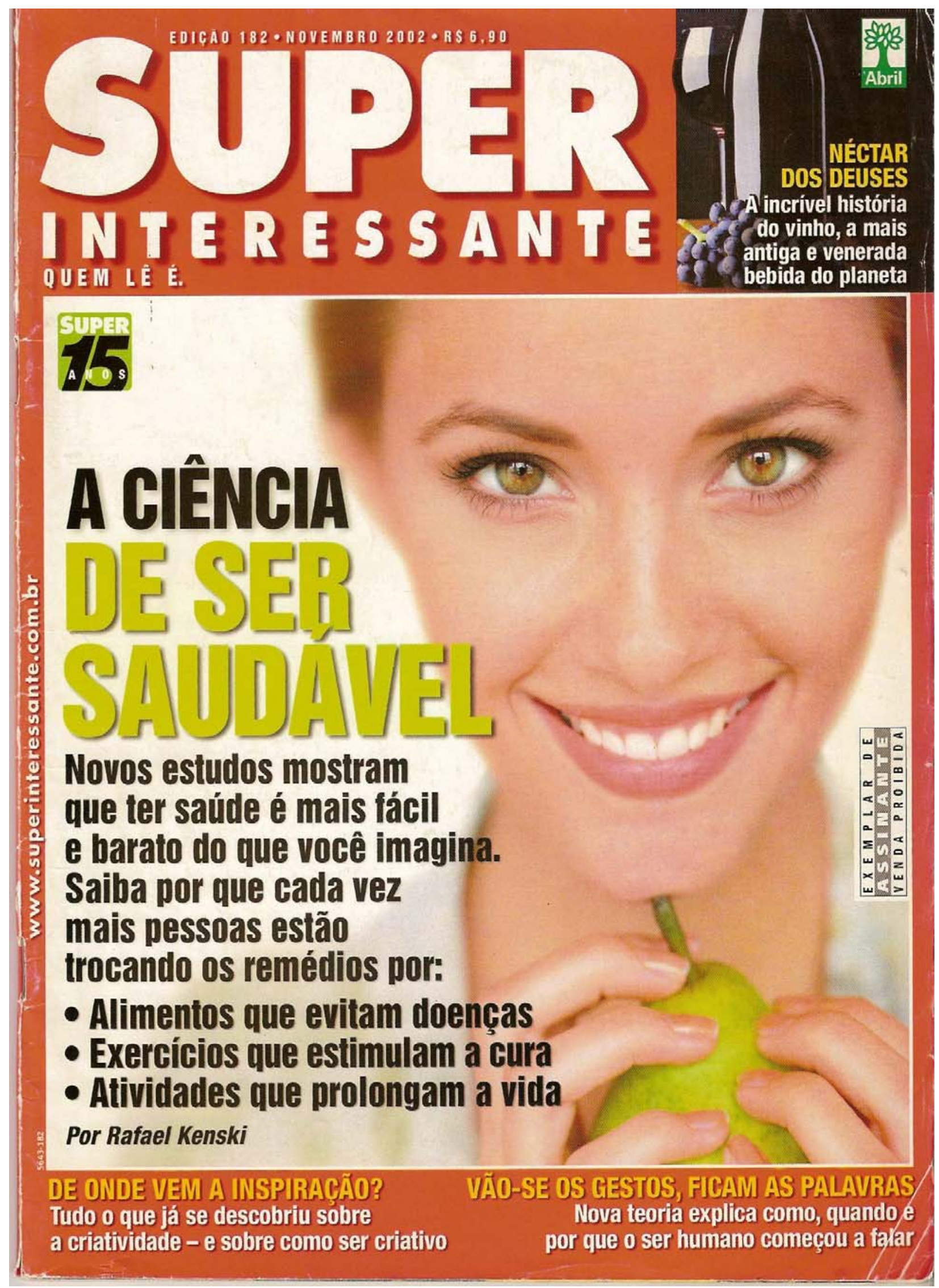


estimular, prolongar que parecem quase formar uma escala. Esses três verbos têm em comum o traço semântico [+futuro]. Evita-se algo para que não aconteça no futuro, estimula-se algo para ver as conseqüências no futuro e, por fim, prolonga-se algo para o futuro. Há também a palavra remédio que figura no mesmo campo semântico de médico, medicina, farmácia, experiências químicas, descobertas científicas etc. No entanto, essa palavra e todo o campo semântico que ela carrega implicitamente deve ser trocada por alimentos, exercícios, atividades que estão mais próximas do campo semântico do cotidiano de todas as pessoas. Logo, além da foto, estas palavras também estão em estreita ligação com a ideologia do cotidiano.

Se no título da edição de março de $1988^{38}$, não havia um agente da cura, aqui, o agente da prevenção e da manutenção da saúde são as próprias pessoas. São elas que devem trocar os remédios por alimentos, exercícios e atividades que, aliás, parecem fazer o papel de agentes por estarem acompanhados não de adjetivos, mas de orações subordinadas adjetivas. Retomados pelo pronome relativo que, esses termos parecem "praticar" a ação de evitar, estimular e prolongar.

O título desta edição, portanto, dialoga explicitamente com o leitor. Esse diálogo é fortemente explicitado no uso do dêitico você em "é mais fácil e barato do que você imagina" e também na presença do imperativo saiba, já usado na primeira e na terceira edições deste terceiro período: "Saiba o que é fato e o que é lenda no debate sobre o vegetarianismo" (Superinteressante - abril de 2002) e "Tudo o que você precisa saber para não desenvolver a sua" (Superinteressante - setembro de 2002). A presença deste verbo mostra que a revista quer fazer o leitor saber algo. Esse saber provém da esfera da ciência, mas é a revista quem o divulga, quem tem acesso a ele. Depois que o leitor tem esse saber, ele pode fazer algo, já que esse saber nada mais é do que conselhos que a revista oferece.

Uma outra forma de captar o leitor é a facilidade com que é mostrada a possibilidade de ter saúde. Segundo o título, ter saúde é mais fácil e barato do que o leitor imagina. Do mesmo modo que na edição de abril de 2002, em que se separa o que é fato e o que é lenda sobre o vegetarianismo, aqui se separam as idéias propagadas sobre a saúde que, para a ideologia do cotidiano, ainda é cara, mas que, para a ciência e seu novo modo de encarar a saúde, pode ser muito barata.

A foto da mulher com um belo sorriso, aparentando uma boa pele e com uma fruta na mão demonstra que hoje em dia as pessoas devem se cuidar sozinhas, sem precisar recorrer a

\footnotetext{
38 “DOR. ESTE TORMENTO PODE ACABAR".
} 
especialistas, embora ainda sejam eles que vão dar essas dicas de prevenção. Nesta edição, o tema da saúde caminha para outra direção, o foco não são mais a cura e as descobertas científicas para ela, mas a prevenção de doenças. A cura ainda se mostra presente no título, mas ela seria realizada por meio de exercícios que o leitor pode fazer sozinho: “• Exercícios que estimulam a cura".

O título do interior da reportagem, que aparece na parte inferior da primeira página, dialoga com vários elementos do título da capa: "DEMITA SEU MÉDICO”. O primeiro diálogo é entre a palavra demita e a palavra barato presente na capa. Uma vez que o leitor vai demitir seu médico, sobrará mais dinheiro no orçamento e o cuidado com a saúde ficará mais barato. A saída do médico dialoga com a troca de remédios pelos alimentos que evitam doenças, exercícios que estimulam a cura e pelas atividades que prolongam a vida.

É nesta mesma direção que vai o tema presente no título da edição de fevereiro de 2003.

\subsubsection{Superinteressante - fevereiro de 2003}

O título desta edição é "PRECISAMOS DE TANTO REMÉDIO? O consumo indiscriminado - e crescente - de medicamentos, aliado à voracidade comercial dos grandes laboratórios e à irresponsabilidade de muitos médicos, cria um novo tipo de dependente: o viciado em drogas legais. Você é um deles?". Como se vê, este título reúne todas as características dos títulos anteriormente analisados: grande quantidade de informações, presença de discurso direto substituído, diálogo explícito com o leitor por meio do dêitico você e mudança temática.

Esta edição traz duas perguntas que envolvem diretamente o leitor e que, pela própria característica deste tipo de sentença (perguntas) pressupõe-se um diálogo com o leitor. Mas há diferenças entre elas. Enquanto a primeira trata da presença de um discurso direto substituído, a segunda não possui essa mistura de vozes: é uma pergunta formulada pela revista para o leitor.

A presença de discurso direto substituído aparece por meio da pergunta "PRECISAMOS DE TANTO REMÉDIO?”. É uma pergunta que o leitor faz, mas que vem concretizada pela voz da revista. Sabe-se que o dêitico nós pode ser inclusivo (eu + você/ eu + vocês) ou exclusivo (eu + ele ou ela/ eu + eles ou elas). Nesta pergunta, temos claramente a presença de um nós inclusivo, ou seja, eu, jornalista, e você, leitor, precisamos de tanto remédio? Ao se incluir dentro do amplo conjunto de pessoas que possuem inúmeras dúvidas diante da ciência, a voz da revista, no lugar 


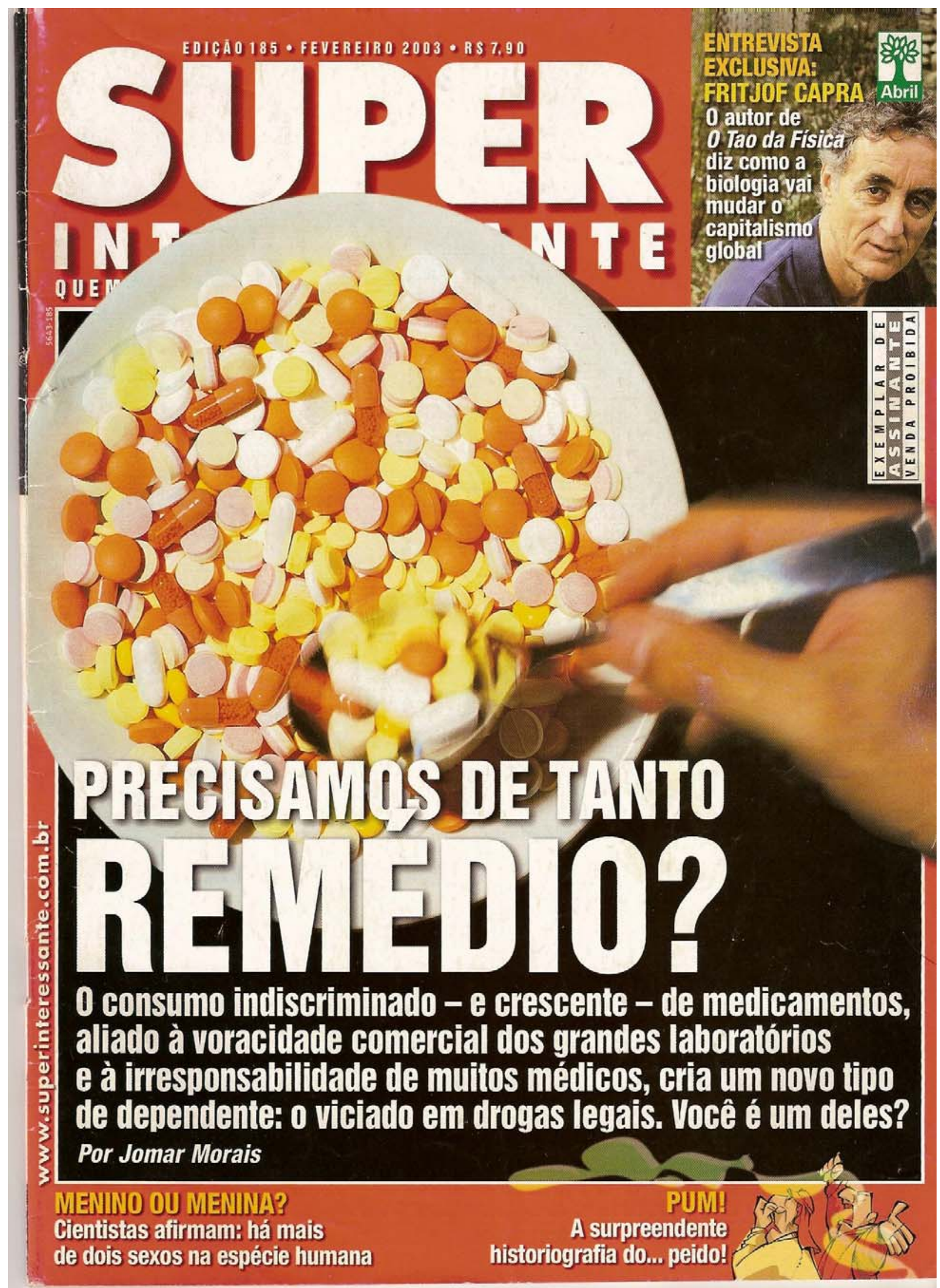


de passar desconfiança ao leitor por também não saber, iguala-se a ele, gerando uma cumplicidade, para, em seguida, mostrar que ela detém a resposta que ajudará e socorrerá a todos. Trata-se de um saber que questiona o saber científico. Dado o tema (prevenção da saúde pelo próprio indivíduo e não pela ciência), a voz da revista já não precisa mais estar ao lado da ciência, que antes detinha o conhecimento, mas sim ao lado do grande público. Contudo, se antes era a ciência que mantinha uma relação assimétrica com o leitor por possuir um saber e o leitor não, agora é a revista que mantém essa relação, mantendo também a dependência do leitor para a obtenção de informações.

Se antes a voz da revista se aliava à voz da ciência, agora, a voz da revista questiona a credibilidade desta usando adjetivos e substantivos que carregam julgamentos nada imparciais como acreditamos que não deveria haver no discurso jornalístico: consumo indiscriminado, voracidade comercial, irresponsabilidade de muitos médicos.

De acordo com este título, podemos ler um resumo da história da medicina e da ciência que, com a credibilidade de suas vozes, prescreveram ao longo de várias décadas, o uso de medicamentos a vários pacientes. Como Bakhtin/Voloshinov afirmam, trata-se do diálogo com os enunciados anteriores que todo enunciado carrega. Assim, todo e qualquer leitor pode se identificar com esse título já que, pelo menos uma vez na vida, um medicamento a ele foi receitado ${ }^{39}$. Assim, com essa fácil identificação, há também fácil captação do leitor.

A voz da revista vai ainda mais longe ao noticiar que hoje em dia temos "um novo tipo de dependente: o viciado em drogas legais". E, ao enunciar a segunda pergunta presente no título "Você é um deles?", explicita o diálogo com o leitor, intimidando-o para um diagnóstico urgente: verificar se é ou não viciado e dependente. O uso desses dois termos assusta o leitor, pois ninguém quer ser considerado viciado em drogas sejam elas ilegais ou mesmo legais.

A foto da capa mostra a mão de um indivíduo segurando uma colher e se alimentando de vários medicamentos espalhados num prato, como se ingerir medicamentos fosse um hábito tão normal quanto ingerir alimentos todos os dias. Um prato cheio de pílulas de remédios diferentes sendo pegas pela mão de um indivíduo articula-se à parte verbal "consumo indiscriminado" e contrasta com a pergunta "Precisamos de tanto remédio?".

\footnotetext{
${ }^{39}$ Inclusive, ao longo da reportagem, descobrimos que o Brasil é o quinto maior consumidor de medicamentos do mundo.
} 
O título do interior da reportagem, "VICIADOS EM REMÉDIOS", retoma a parte que dialoga explicitamente com o leitor na capa. A palavra viciados aparece com a cor preta e em remédios possui a cor vermelha. O sintagma ocupa a parte superior da segunda página da reportagem. Ao retomar a parte que mais dialoga e assusta o leitor, a voz da revista incita-o a ler a reportagem para fazer um diagnóstico dele mesmo: trocam-se os consultórios médicos pela leitura da revista como ocorreu na edição anterior. A revista é capaz de fazer diagnósticos e dar conselhos para preservar a saúde.

\subsubsection{Superinteressante - outubro de 2003}

Ilustrando um tipo de atividade recomendada na edição de novembro de 2002, nesta edição temos como tema a meditação: "MEDITAÇÃO. O que é, para que serve, o que a ciência diz a respeito e por que tanta gente está praticando". Embora não haja ponto de interrogação, os enunciados que aparecem depois de "MEDITAÇÃO" são perguntas indiretas e poderiam ser lidas também como discursos diretos substituídos, isto é, perguntas que são preenchidas por pelo menos duas vozes, a do jornalista e a do leitor. Entretanto, ao não usar os pontos de interrogação, essas perguntas parecem ser sub-tópicos daquilo que será exposto na reportagem.

Embora venha na mesma direção dos dois títulos anteriores, em que o indivíduo deve mais se prevenir do que se preocupar com uma doença e sua cura, a ciência ainda se faz bastante presente para validar o discurso da prevenção. O discurso científico é ainda usado para sustentar as idéias presentes nesse novo caminho da saúde. Na edição de novembro de 2002, temos “A CIÊNCIA DE SER SAUDÁVEL" (grifo meu), em que a ciência se faz presente até mesmo na estrutura lingüística do enunciado. Nesta edição, há o enunciado "o que a ciência diz a respeito", evidenciando também para a importância desse discurso na reportagem.

A foto da capa, assim como na edição de novembro de 2002, traz uma mulher se cuidando, fazendo meditação no meio da natureza. A calça branca, o cabelo amarrado, a falta de maquiagem e de acessórios como brincos e colares, contribuem para uma imagem natural e saudável.

O título do interior da reportagem, "É SÓ RESPIRAR”, dialoga com a mudança temática que esse novo período traz: “prevenir é fácil e barato". A presença do operador argumentativo só projeta o verbo respirar no ponto extremo de uma escala, dando a ele o sentido de ser a ação mais fácil de se realizar. De fato, na própria semântica de respirar já encontramos essa facilidade, 


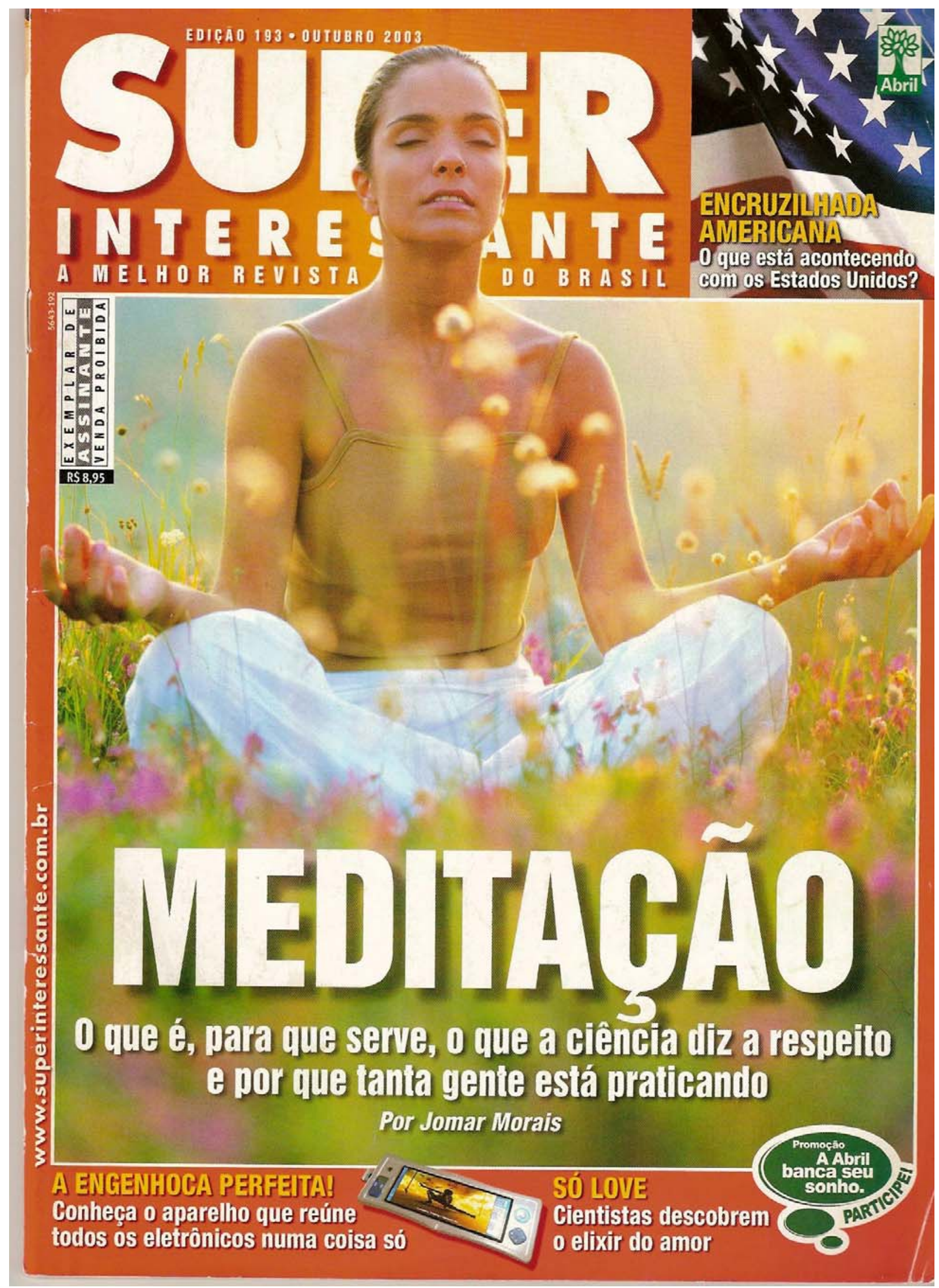


uma vez que, na grande maioria dos casos, não nos esforçamos para fazê-lo. A presença do operador só reforça a facilidade da meditação e, conseqüentemente, dos benefícios que ela traz à saúde. Esse enunciado é uma recomendação disfarçada, ou seja, não há nenhum verbo na forma imperativa, mas o argumento da facilidade pretende convencer o leitor a criar novos hábitos.

\subsubsection{Síntese dos títulos e imagens do terceiro período}

Pode-se dizer que os títulos deste período apresentam as seguintes regularidades: 1) presença de discurso direto substituído. Ao enunciar o título com este procedimento, a revista leva em conta o fundo aperceptível do leitor, isto é, suas dúvidas, suas crenças, suas convicções (ou a falta delas), seus conhecimentos presumidos sobre determinado assunto. Ao fazê-lo, cria uma cumplicidade com o leitor ao mesmo tempo em que age no sentido de sanar as dúvidas, modificar as crenças;

2) aumento considerável de informações em relação aos outros períodos. O estilo dos títulos deste período aponta não só para esse novo modo de lidar com o leitor (por meio da cumplicidade construída em forma de discurso direto substituído), como também aponta para a competitividade que se instalou no comércio de revistas comerciais de divulgação científica;

3) diálogo com o leitor explicitado pelo dêitico você, mostrando que a reportagem foi feita exclusivamente para o leitor que se torna, por este fato, participante explícito desta comunicação discursiva;

4) mudança temática. Se antes o tema era a cura de doenças, agora o tema é a preservação de doenças. A revista se reveste de um caráter aconselhador, tendo como finalidade orientar o leitor na maneira como preservar sua saúde.

\subsection{Análise do discurso citado}

\subsubsection{Superinteressante - abril de 2002}

Para falar sobre o consumo da carne e a opção pelo vegetarianismo, esta reportagem é constituída de 9 páginas e 47 parágrafos. A quantidade de parágrafos é bem maior, se comparada 
à dos outros períodos. Entretanto, diferenciando-se das demais reportagens analisadas, esta não possui nenhum boxe. É como se os textos que constituiriam os boxes estivessem integrados na reportagem. Há somente um boxe bastante pequeno ("O boi no mundo") que traz um gráfico. Ele quase não aparece no meio das 11 fotos que compõem a reportagem. As fotos são bastante chamativas e assustadoras, uma vez que muitas mostram animais mortos. Todas as páginas contêm fotos e elas sempre aparecem na parte superior. Os parágrafos estão distribuídos da seguinte maneira: introdução (par.1-2); "O que é carne?" (par.3-6); "Números, números, números" (par.7-8); “Todos os tipos de vegetarianos" (par.9); “Carne faz mal?” (par.10-17); "Dá para viver sem carne?" (par.18-23); "Somos vegetarianos por natureza?" (par.24-28); "Vaca, a onipresente" (par.29-31); "O planeta precisa de carne?" (par.32-34); "Como vivem - e morrem os animais?" (par.35-40); "E o que fazer a respeito?" (par.41-44); “A vaca e a humanidade" (par.45-47).

Como se vê, muitos dos sub-títulos são formados de perguntas em forma de discurso direto substituído que sugerem dúvidas do próprio leitor e os parágrafos que vêm logo após esses sub-títulos procuram responder a elas. Desse modo, o leitor pode até mesmo ler apenas alguns trechos das reportagens, somente aqueles dos quais ele tem dúvida. Ao articular a reportagem em perguntas, selecionando e separando os sub-tópicos, a revista facilita a leitura, fragmentando o assunto e atraindo todos os tipos de leitores: aqueles que querem ter um amplo conhecimento do assunto, aqueles que se interessam mais pela questão dos animais, aqueles que buscam alguma alternativa etc.

Vejamos quais são os tipos de discursos citados que aparecem na reportagem:

\begin{tabular}{|l|l|}
\hline Tipo de discurso & \multicolumn{1}{|c|}{ Reprodução } \\
\hline $\begin{array}{c}\text { Discurso Direto } \\
\text { Preparado }\end{array}$ & 1) A maior parte do mundo médico ainda acredita na malignidade da carne vermelha e da \\
manteiga. ("Não tenho dúvidas da relação entre gordura saturada e doenças cardiovasculares", \\
afirma o nutricionista argentino Célio Morón oficial da agência da ONU que cuida de \\
alimentação, a FAO. Denise Coutinho, que coordena a política de nutrição do governo \\
brasileiro, repetiu quase as mesmas palavras) (p.14).
\end{tabular}




\begin{tabular}{|c|c|}
\hline & 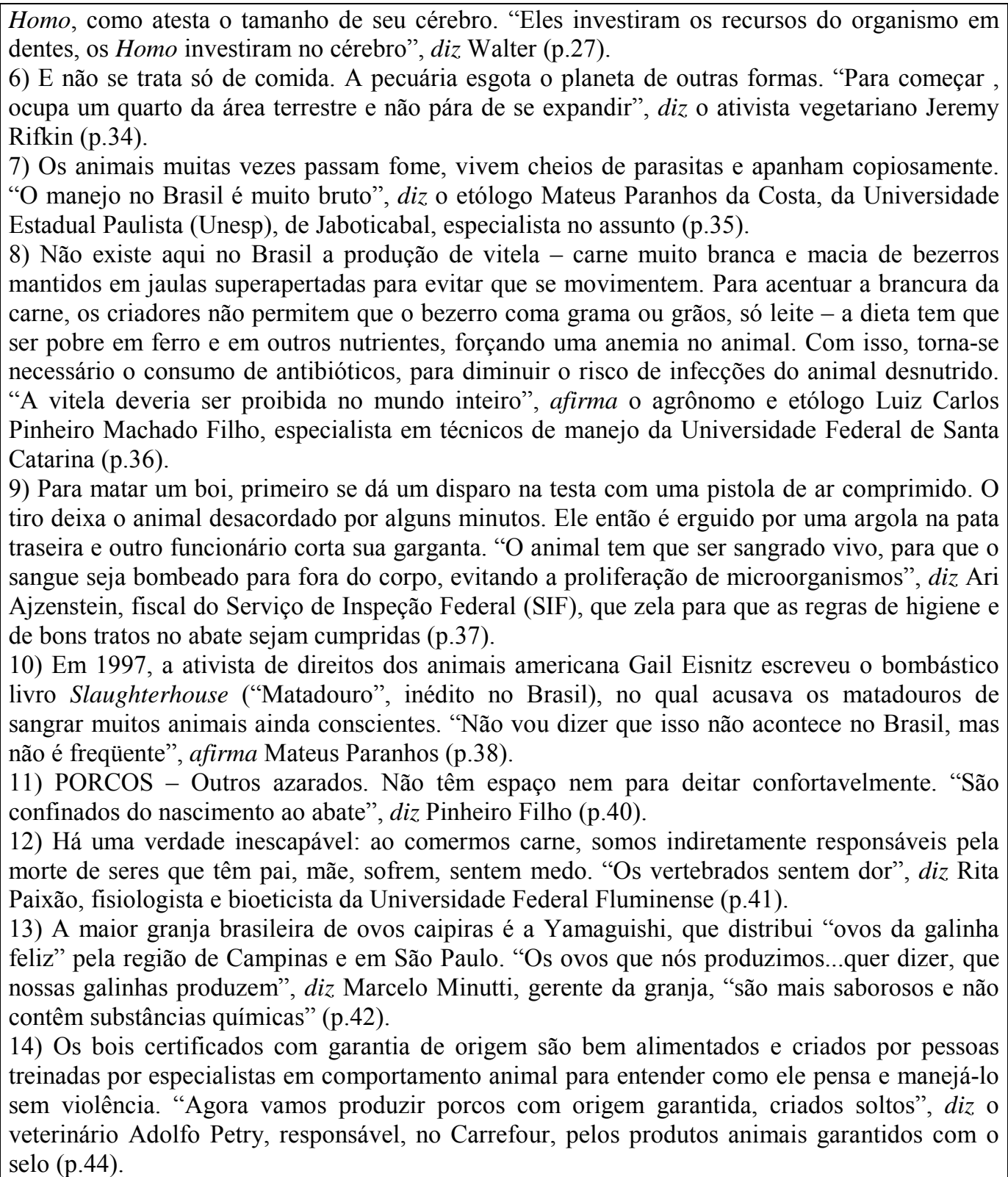 \\
\hline $\begin{array}{l}\text { Discurso Direto } \\
\text { seguido de síntese } \\
\text { do jornalista }\end{array}$ & $\begin{array}{l}\text { 1) "O homem tem dentes pequenos e sistema digestivo curto, características de onívoros", } \\
\text { afirma o antropólogo físico Walter Neves, da Universidade de São Paulo, maior especialista } \\
\text { brasileiro em homens pré-históricos. Ou seja, nosso organismo está preparado para comer de } \\
\text { tudo, inclusive carne (p.24). }\end{array}$ \\
\hline $\begin{array}{l}\text { Discurso Indireto } \\
\text { Analisador da } \\
\text { Expressão }\end{array}$ & $\begin{array}{l}\text { 1)OVOLACTOVEGETARIANOS - Não comem carne de nenhum tipo, mas consomem ovos, } \\
\text { leite e derivados. Em geral, quando alguém diz que é "vegetariano", é essa dieta que ele segue } \\
\text { (p.9). } \\
\text { 2)LACTOVEGETARINOS - Provavelmente o mais numeroso dos grupos, já que essa dieta é } \\
\text { predominante no sul da Índia - por razões religiosas. Nada de carne, mas leite e derivados estão } \\
\text { liberados. O ovo é terminantemente proibido, por conter a "vibração da vida" (p.9). } \\
\text { 3) No ano passado, Gary Taubes, correspondente da revista americana Science e um dos } \\
\text { principais escritores de ciência do mundo, escreveu um longo artigo no qual classificava o medo } \\
\text { da gordura saturada como "dogma" (p.13). } \\
\text { 4) Já para os vegans, a palavrinha mágica é "soja" (p.21). }\end{array}$ \\
\hline $\begin{array}{c}\text { Discurso Indireto } \\
\text { Analisador do }\end{array}$ & $\begin{array}{l}\text { 1)Taubes afirma que, mesmo com tanta pesquisa, não há prova de que gordura saturada e } \\
\text { enfartes estão ligados. E vai além: diz que a propaganda do governo só serviu para fazer com }\end{array}$ \\
\hline
\end{tabular}




\begin{tabular}{|c|c|}
\hline Conteúdo & $\begin{array}{l}\text { que os americanos comessem mais - ao evitar gordura, eles acabavam ingerindo mais } \\
\text { carboidratos, mais açúcar, para manter a quantidade diária de calorias (o corpo tende a reclamar } \\
\text { quando as calorias são insuficientes para saciá-lo - isso se chama fome) (p.13). } \\
\text { 2) Muitos nutricionistas afirmam que as crianças não devem, de maneira nenhuma, ficar sem } \\
\text { proteína animal, sob risco de terem o desenvolvimento cerebral prejudicado (p.18). } \\
\text { 3) Denise Coutinho, responsável pela política nutricional do governo federal, adiantou à SUPER } \\
\text { que está em estudo uma medida para tornar a fortificação com ferro obrigatória nas farinhas de } \\
\text { trigo e de milho (p.20). } \\
\text { 4) Walter afirma que, num passado longínquo, nos alimentávamos como chimpanzés (p.25). } \\
\text { 5) Há quem diga que o problema de comer carne é moral: não teríamos o direito de matar para } \\
\text { comer (p.29). } \\
\text { 6) Gail Eisnitz afirma, em seu livro, que muitos porcos caem na água fervendo ainda vivos, mas } \\
\text { isso provavelmente é incomum (p.40). }\end{array}$ \\
\hline $\begin{array}{l}\text { Discurso Direto } \\
\text { Substituído }\end{array}$ & $\begin{array}{l}\text { 1) Carne faz mal, então? Não é tão simples (p.10). } \\
\text { 2) Mas, afinal, o que sobra da discussão? (p.15). } \\
\text { 3) O que os está salvando dos ataques cardíacos? Os legumes, o azeite, o vinho, a conversa mole } \\
\text { depois do almoço, a brisa marinha? Ninguém sabe ao certo. Provavelmente é uma conjunção de } \\
\text { todos esses fatores (p.15). } \\
\text { 4) Quer dizer que precisamos comer carne para raciocinar? Não (p.28). }\end{array}$ \\
\hline
\end{tabular}

O discurso direto preparado é o que predomina. São catorze ocorrências e os verbos de elocução utilizados não trazem nenhuma novidade em relação aos outros períodos analisados. Aparecem três vezes o verbo afirmar e onze vezes o verbo dizer. Enquanto este não traz qualquer orientação na interpretação do enunciado, aquele gera o sentido da credibilidade por parte de quem fala, isto é, a pessoa que falou tem poder e conhecimento para afirmar algo.

Uma variação de discurso direto é aquele seguido de síntese do jornalista, em que a fala do cientista aparece sem nenhuma preparação e, em seguida, o jornalista explica com outras palavras ou tira conclusões da afirmação do cientista.

Entretanto, é importante frisar que a fala do cientista, embora sem nenhuma preparação, vem logo após um daqueles sub-títulos em forma de pergunta "Somos vegetarianos por natureza?". Isso acaba criando uma simulação de um diálogo entre leitor e cientista e por que não dizer uma preparação para sua aparição.

A presença do discurso indireto analisador da expressão confirma a tendência dos outros períodos que privilegiam esta forma para citar discursos de outras esferas. No primeiro exemplo, temos os vegetarianos como autores do discurso citado. Trata-se da voz da ideologia do cotidiano. No segundo exemplo, é a esfera da religião que aparece concretizado na fala de indianos. No terceiro exemplo é a voz de um jornalista, que não é da Super, mas de outro país. Colocando uma palavra de seu discurso entre aspas, a voz da revista distancia-se da voz dele e, ao mesmo tempo, mostra que as "cores" dos dois discursos são diferentes. No último exemplo, os autores do discurso citado são um outro grupo de vegetarianos, os vegans. 
Ao utilizar o discurso indireto analisador da expressão, a revista coloca um holofote sobre palavras e modo de falar típicos desses grupos, distanciando-se lingüisticamente deles.

Já nas ocorrências de discurso indireto analisador do conteúdo os autores são cientistas, com exceção dos seguintes casos:

1) Há quem diga que o problema de comer carne é moral: não teríamos o direito de matar para comer (p.29).

2) Gail Eisnitz afirma, em seu livro, que muitos porcos caem na água fervendo ainda vivos, mas isso provavelmente é incomum (p.40).

No primeiro caso, o autor, concretizado pelo pronome quem, pode ser várias pessoas que têm a opinião que aparece a seguir. Assim, esse discurso aproxima-se mais da ideologia do cotidiano, uma vez que são muitas pessoas dizendo a mesma coisa e não um cientista com uma informação diferente para falar. O discurso indireto analisador do conteúdo é preferido neste caso por não dar voz a um único autor. Não seria plausível colocar aspas num discurso em que o autor são várias pessoas ${ }^{40}$.

O exemplo 2 não traz igualmente um cientista como autor. Trata-se de uma escritora que defende e denuncia o maltrato com os animais. Para se distanciar semanticamente do discurso dela, o discurso do jornalista se valeu de uma oração coordenada adversativa ("mas isso provavelmente é incomum").

Nos outros casos, o autor é um cientista e o contexto narrativo procura se distanciar apenas sintaticamente do discurso citado, marcando bem as fronteiras entre um e outro, mas não semanticamente.

Há ainda um caso que mostra a exclusividade de informações que a revista obteve:

Denise Coutinho, responsável pela política nutricional do governo federal, adiantou à SUPER que está em estudo uma medida para tornar a fortificação com ferro obrigatória nas farinhas de trigo e de milho (p.20).

O verbo de elocução utilizado nesta ocorrência, adiantar, leva-nos à interpretação de que a revista possui informações exclusivas, ela está adiantada, à frente de qualquer outro meio de comunicação. Por meio da utilização deste verbo a revista ganha a confiança do leitor e acaba fidelizando-o.

As três ocorrências de discurso direto substituído vêm se somar ao título da capa e aos sub-títulos que também estão em forma de perguntas. Essa parece ser uma tendência já iniciada no segundo período de colocar em cena as dúvidas e as perguntas que um leitor faria. Cria-se, deste modo, um diálogo explícito entre leitor e jornalista, este último tendo o poder de sanar as 
dúvidas por meio das informações que possui da esfera científica. Nesta reportagem, a própria revista fornece as respostas e não necessariamente um cientista como ocorreu em outras reportagens em que este tipo de pergunta ${ }^{41}$ apareceu:

Carne faz mal, então? Não é tão simples (p.10).

Do mesmo modo que nas reportagens anteriores, o cientista é caracterizado por sua especialidade e por sua instituição, o que confere credibilidade ao discurso proferido:

A questão é a seguinte: suprir suas necessidades protéicas com carne é fácil. "Afinal, você é feito de carne", diz Pedro de Felício, especialista em produtos de origem animal da Universidade Estadual de Campinas (UNICAMP) (p.21).

\subsubsection{Superinteressante - agosto de 2002}

Igualmente à edição de agosto de 1995, este período também traz o tema da maconha como reportagem de capa. A discussão polêmica sobre o uso terapêutico da erva continua nesta reportagem, a grande diferença é a quantidade de informações históricas acerca da maconha. Assim, muitos livros sobre esse assunto são citados pelo jornalista que, no início da reportagem, justifica sua pesquisa:

Não é fácil falar desse assunto - admito que levei um dia inteiro para compor o parágrafo acima. O tema é tão carregado de ideologia e as pessoas têm convicções tão profundas sobre ele que qualquer convite ao debate, qualquer insinuação de que estamos lidando mal com o problema já é interpretada como "apologia às drogas" e, portanto, punível com cadeia. O fato é que, apesar da desinformação dominante, sabe-se muito sobre a maconha. Ela é cultivada há milênios e centenas de pesquisas já foram feitas sobre o assunto. O que tentei fazer foi condensar nestas páginas o conhecimento que a humanidade reuniu sobre a droga nos milênios em que convive com ela (par.2).

A “condensação" de que fala o jornalista ocupa 9 páginas da revista, em uma reportagem que possui 53 parágrafos distribuídos da seguinte maneira: introdução (par.1-2); "Por que é proibido?" (par.3-15); "Maconha faz mal?” (par.16-31); "Maconha faz bem?” (par.32-40); “O passado" (par.41-49); “O presente” (par.50-51); “O futuro” (par.52-53). Como se vê, os primeiros sub-títulos possuem muitos parágrafos, entretanto, eles são "quebrados" por olhos que constituem repetições de algo já falado na reportagem. Há a presença de três olhos no meio dos parágrafos que constituem os primeiros sub-títulos. Este recurso é uma novidade neste período. A presença deste recurso parece justificar a ausência de boxes, tão presentes nos outros períodos. Como não há a "quebra" da reportagem por meio dos boxes, utilizaram-se alguns olhos; no entanto, com os

\footnotetext{
${ }^{40} \mathrm{O}$ mesmo ocorre com o exemplo 2 da tabela.

${ }^{41}$ Mas como será que ficam as pessoas com saúde normal, que confiam no almoço apressado do dia-a-dia? Elas também deveriam apelar para suplementos? "O melhor caminho é corrigir a dieta", defende Vanucchi. "Se isso for impossível, as cápsulas sempre serão uma opção” (par.10). (Superinteressante - março de 1995)
} 
olhos, a "quebra" na página é bem menor, ocupa menos espaço. O conteúdo que poderia vir nos boxes parece estar integrado à reportagem, uma vez que, como na reportagem anterior, há um número de parágrafos muito grande.

Seguindo a tendência da reportagem anterior, a utilização de discurso direto substituído nos sub-títulos também ocorre aqui, projetando as dúvidas do leitor em lugar de destaque nas reportagens (os sub-títulos).

Apesar da falta de boxes, há desenhos de ervas que ocupam toda a segunda página da reportagem, 3 reproduções de cartazes que condenavam o uso da maconha na primeira metade do século e, ainda, 4 fotos.

Os discursos citados que compõem a reportagem estão reproduzidos na tabela a seguir:

\begin{tabular}{|c|c|}
\hline Tipos de discurso & Reprodução \\
\hline $\begin{array}{l}\text { Discurso Direto } \\
\text { Preparado }\end{array}$ & 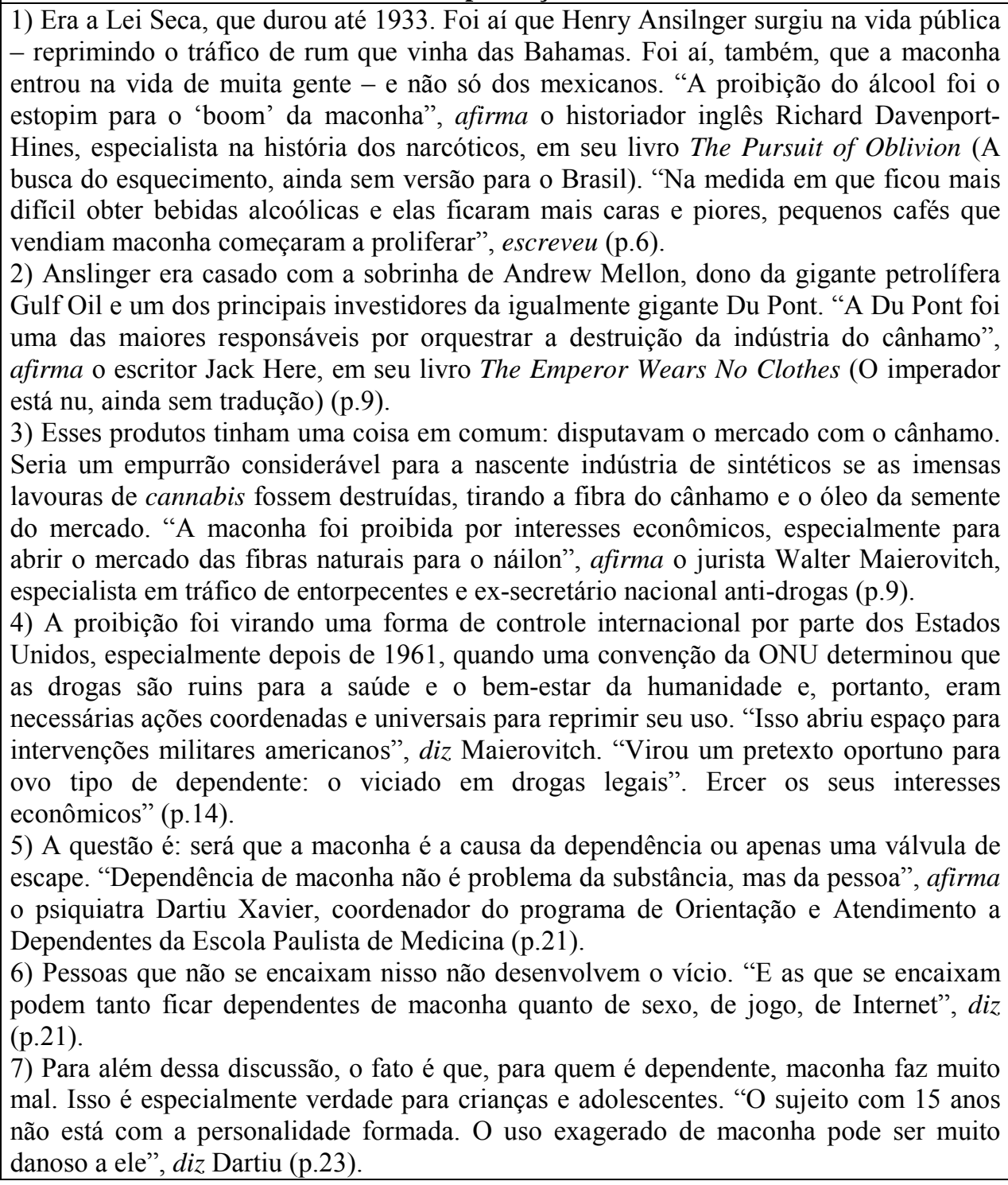 \\
\hline
\end{tabular}




\begin{tabular}{|c|c|}
\hline & 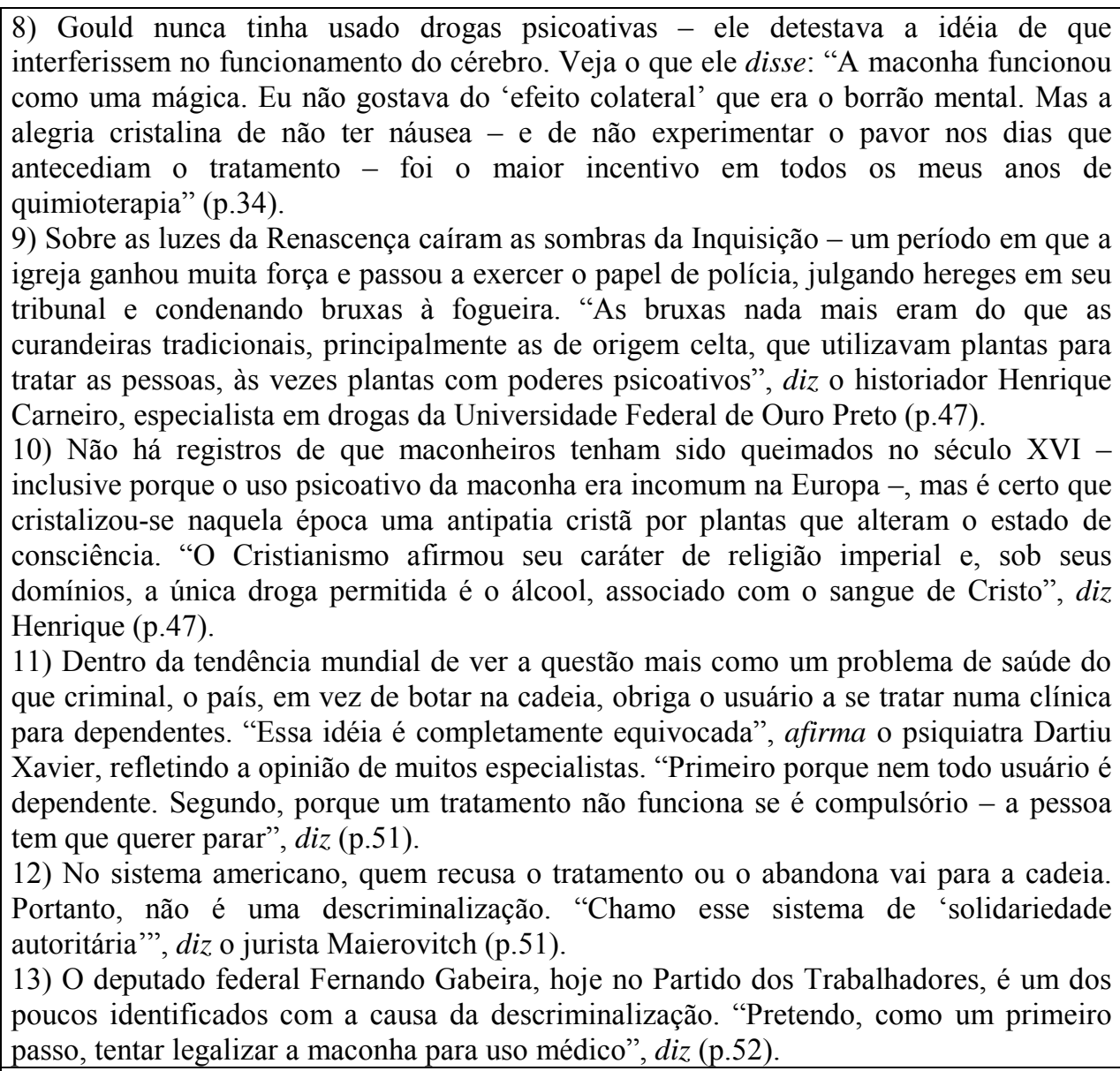 \\
\hline $\begin{array}{l}\text { Discurso Direto seguido } \\
\text { de síntese do jornalista }\end{array}$ & $\begin{array}{l}\text { 1) "A proibição das drogas serve aos governos porque é uma forma de controle social das } \\
\text { minorias", diz o cientista político Thiago Rodrigues, pesquisador do Núcleo de Estudos } \\
\text { Interdisciplinares sobre Psicoativos. Funciona assim: maconha é coisa de mexicano, } \\
\text { mexicanos são uma classe incômoda. "Como não é possível proibir alguém de ser } \\
\text { mexicano, proíbe-se algo que seja típico dessa etnia", diz Thiago (p.13). } \\
\text { 2) "Maconha mata neurônios". Essa frase, repetida há décadas, não passa de mito. } \\
\text { Bilhões de dólares foram investidos para comprovar que o THC destrói tecido cerebral - } \\
\text { às vezes com pesquisas que ministravam doses de elefantes em ratinhos -, mas nada foi } \\
\text { encontrado (p.24). }\end{array}$ \\
\hline $\begin{array}{c}\text { Discurso Indireto } \\
\text { Analisador do Conteúdo }\end{array}$ & $\begin{array}{l}\text { 1) Outros adoram e relatam que ela ajuda a aumentar a criatividade, a relaxar, a melhorar } \\
\text { o humor, a diminuir a ansiedade (p.32). } \\
\text { 2) O jurista afirma que há uma enorme influência americana na política de drogas } \\
\text { brasileira (p.52). }\end{array}$ \\
\hline $\begin{array}{c}\text { Discurso Indireto } \\
\text { Analisador do Conteúdo } \\
\text { (com modalizadores) }\end{array}$ & $\begin{array}{l}\text { 1) Também é verdade que o fumante de maconha tem comportamentos mais arriscados } \\
\text { que o de cigarro: traga mais profundamente, não usa filtro e segura a fumaça por mais } \\
\text { tempo no pulmão (o que, aliás, segundo os cientistas, não aumenta os efeitos das drogas) } \\
\text { (p.20). } \\
\text { 2) Segundo Dartiu, há um perfil claro do dependente de maconha: em geral, ele é jovem, } \\
\text { quase sempre ansioso e eventualmente depressivo (p.21). } \\
\text { 3) Segundo o farmacólogo Leslie Iversen, autor do ótimo The Science of Marijuana (A } \\
\text { ciência da maconha, sem tradução para o português) e consultor para esse tema da } \\
\text { Câmara dos Lordes (o Senado inglês), esses temores são exagerados e o aumento da } \\
\text { concentração de THC não foi tão grande assim (p.22). } \\
\text { 4) Segundo o farmacólogo inglês Iversen, não há dúvidas de que ela seja um remédio útil } \\
\text { para muitos e fundamental para alguns, mas há um certo exagero sobre seus potenciais } \\
\text { (p.33). }\end{array}$ \\
\hline
\end{tabular}




\begin{tabular}{|c|l|}
\hline & 5) Segundo eles, a maconha é um remédio feito sob medida para combater a dependência \\
de crack e cocaína, porque estimula o apetite e combate a ansiedade, dois problemas \\
sérios para cocainômanos (pa.40). \\
6) E as grandes navegações foram impulsionadas por velas de cânhamo - segundo o \\
autor americano Rowan Robinson, autor de O Grande Livro da Cannabis, havia 80 \\
toneladas de cânhamo, contando o velame e as cordas, no barco comandado por \\
Cristóvão Colombo em 1496 (p.46). \\
7) Segundo dados da ONU, 147 milhões de pessoas fumam maconha no mundo, o que \\
faz dela a terceira droga psicoativa mais consumida do mundo, depois do tabaco e do \\
álcool (p.50).
\end{tabular}

O discurso direto preparado é o tipo de discurso citado que predomina, com treze ocorrências. Os verbos de elocução utilizados são exatamente os mesmos nos discursos diretos preparados da reportagem anterior: cinco ocorrências do verbo afirmar e oito do verbo dizer. Duas destas citações foram retiradas de livros (exemplos 1 e 2).

O jornalista informa que não há tradução para o português o que mostra que as fontes não são só brasileiras, há referências internacionais. O leitor, desta forma, pode se sentir mais bem informado e também mais confiante. Além disso, ele percebe que está lendo um assunto de âmbito internacional, gerando uma importância ainda maior ao tema tratado.

A presença de discurso direto seguido de síntese de jornalista aponta para uma tendência de se iniciar o período com uma citação e, em seguida, haver uma explicação por parte do jornalista. Este recurso faz do contexto narrativo não só um "preparador" de discursos citados, mas também um "comentarista" (exemplo 2) e/ou aquele que tem a capacidade de explicar o discurso científico de forma mais clara (exemplo 1). 
O discurso indireto analisador do conteúdo foi utilizado para dois discursos citados cujos autores não são cientistas. Trata-se de discursos de outras esferas da atividade: o primeiro refere-se à ideologia do cotidiano e o segundo à esfera do direito.

Já nas presenças de discurso indireto analisador do conteúdo com modalizadores, os autores são, em sua maioria, os cientistas. Há somente uma ocorrência em que o autor é uma instituição (exemplo7).

Com esses dados, parece que, quando se quer manter mais distância sintática em relação à fala de outrem, prefere-se o discurso indireto com modalizadores. Já quando o autor do discurso citado não é considerado tão importante na esfera da ciência como os cientistas o são, utiliza-se o discurso indireto analisador do conteúdo ou, ainda, o discurso indireto analisador da expressão, que contou com quatro ocorrências sendo que em nenhuma delas o autor era um cientista. No primeiro exemplo, o discurso citado provém da ideologia do cotidiano; no segundo, é um funcionário do governo dos EUA; o terceiro exemplo também se trata do governo dos EUA e, por fim, no último exemplo temos a Câmara Municipal do Rio de Janeiro como autora do discurso citado.

Seguindo a tendência de todos os períodos, o discurso indireto analisador da expressão é a forma mais utilizada para citar discursos provenientes de outras esferas.

Por fim, a presença de dois discursos diretos substituídos sinalizam para a permanência de uma tendência, iniciada já no segundo período, de incluir, num mesmo enunciado, o discurso do leitor e o discurso do jornalista. Ao contrário, entretanto, das perguntas no título da capa e nos sub-títulos da reportagem, os que aparecem no contexto narrativo são rapidamente atribuídas a uma única voz já que a reposta, dada pela voz do jornalista ou do cientista, aparece logo em seguida, mostrando que a dúvida pertence somente ao leitor e não ao jornalista ou ao cientista que são aqueles que detêm o saber.

Embora a reportagem traga vozes de outras esferas da atividade humana, percebemos, por meio da preferência de um ou outro procedimento de transmissão da fala do outro, que o discurso da ciência é o que é posto de forma mais integral, isto é, não são apenas fragmentos de falas dos cientistas que aparecem, como no caso do discurso indireto analisador da expressão. 


\subsubsection{Superinteressante - setembro de 2002}

Esta reportagem possui 43 parágrafos distribuídos em 9 páginas das quais 2 são inteiramente preenchidas por boxes ("Raio X da diabete" e "Por uma vida mais doce"). Em cada página há a foto de dois tipos de doces. Os parágrafos estão distribuídos da seguinte maneira: introdução (par.1-6); "Inimigo silencioso" (par.7-17); "Efeito devastador” (par.18-29); "Mudança de hábito" (par.30-38); "O que há de novo" (par.39-43). Como se vê, contrariando a tendência de haver sub-títulos em forma de perguntas, esta reportagem não exibe nenhum caso deste tipo; todavia, seguindo a última reportagem analisada, apresenta "olhos" que fazem o papel de “quebrar” a página, repetindo algo que foi falado nos parágrafos.

Os discursos citados que compõem a reportagem seguem na tabela abaixo:

\begin{tabular}{|c|c|}
\hline Tipos de discurso & Reprodução \\
\hline $\begin{array}{l}\text { Discurso Direto } \\
\text { Preparado }\end{array}$ & 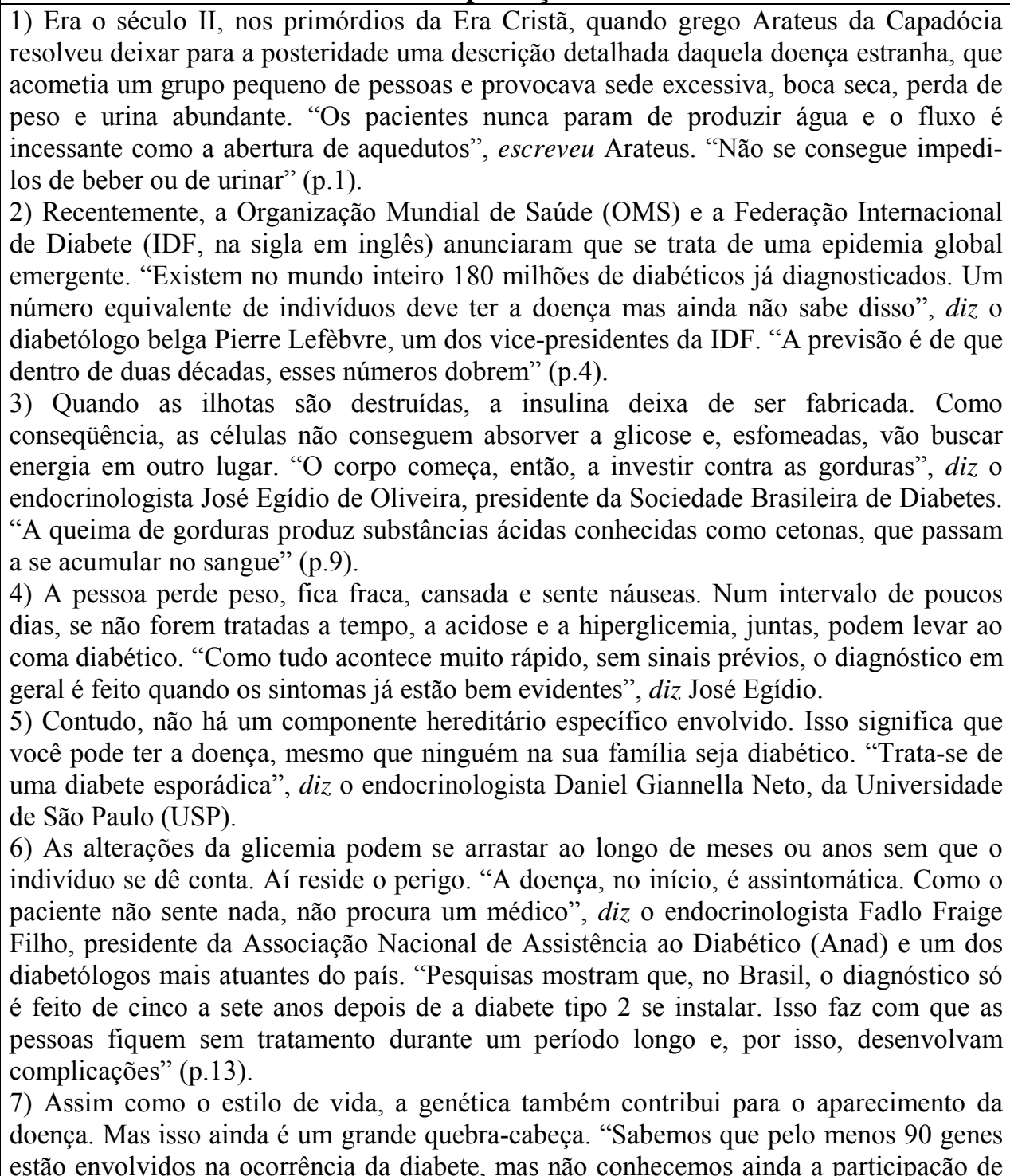 \\
\hline
\end{tabular}


todos eles", afirma Daniel Giannela. "A manifestação da diabete vai depender de quais genes são, de como eles interagem entre si e de como reagem à pressão ambiental" (p.16).

8) Mas o controle rigoroso não significa ausência total de problemas. "Existem determinantes genéticos que podem proteger o paciente de algumas complicações ou predispô-lo a outras", diz Daniel (p.16).

9) Como você não sabe o que seus genes lhe reservam, a melhor garantia de bem-estar é a monitorização das suas taxas de glicose no sangue. "O normal é que a glicemia em jejum fique entre 70 e 110 miligramas por decilitro", diz o endocrinologista Antônio Chacra, da Universidade Federal de São Paulo (Unifesp) (p.17).

10) Para os insulino-dependentes, ou seja, os portadores da diabete do tipo 1, injeções de hormônios são necessárias, sempre. No tipo 2, como o pâncreas continua a produzir insulina, injeções devem ser aplicadas apenas em casos mais extremos. "É duro conviver com a diabete, às vezes me sinto farto", afirma o norueguês Bjornar Allgot, outro dos vice-presidentes da IDF, diabético do tipo 1 há 30 anos. "Brinco com as pessoas: posso emprestar a minha diabete para você por algumas semanas?" Realmente ter férias da doença é um dos meus maiores sonhos"'(p.19).

11) A falta de informação sobre os riscos da diabete, a pouca atenção às medidas de saúde preventivas (devido á mentalidade obsoleta de esperar que a doença apareça para depois tentar vencê-la) e o descaso com o tratamento podem, sim, levar o paciente diabético à morte prematura. "A diabete age como um assassino silencioso", diz Pierre Lefèbvre.

12) Seus efeitos deletérios indicam que as coisas já não estavam indo bem há tempos (a glicemia alta demais, o acúmulo de colesterol no sangue). "O diabético apresenta um risco maior de sofrer um infarto em comparação com um não-diabético que já tenha enfartado", diz Celso. "Por isso, além da glicemia sob controle, quem tem diabete deve manter seus níveis de gordura no sangue sempre baixo e cuidar da pressão sangüínea" (p.22).

13) Por causa disso, os rins não retêm mais as proteínas do sangue, que seguem direto para a urina. O tecido interno do órgão se expande, devido ao excedente de açúcar, comprimindo os vasos sangüíneos. A pressão arterial aumenta. O quadro se agrava até a falência total do órgão. "A diabete é a causa principal da entrada do paciente num programa de diálise, o tratamento com rim artificial”, diz Celso Amodeo (p.24).

14) Perto de 21 milhões de brasileiros foram testados e, desses, um milhão recebeu diagnóstico de diabete, sendo encaminhado para tratamento. "Atividades educativas voltadas para a diabete devem ser realizadas continuamente", diz Fadlo Fraige, que participou da elaboração do programa. "A população precisa se conscientizar da importância do diagnóstico precoce e, principalmente, da prevenção" (p.30).

15) A atividade física diminui a necessidade da insulina e aumenta a tolerância à glicose. "Trata-se de um grande benefício à saúde tanto para quem não tem a diabete e nem virá a tê-la, quanto para quem é diabético ou tem predisposição para a doença", diz Mário (p.34).

16) A atitude preventiva passa também pela correção dos hábitos alimentares, essencial para a manutenção das taxas ideais de glicemia e também para evitar a obesidade. "Dieta virou sinônimo de privação quando, na verdade, significa maneira saudável de se alimentar", diz a nutricionista Ana Maria Lottenberg, da Liga de Diabetes do Hospital das Clínicas de São Paulo (p.35).

17) Apesar de não haver uma cura definitiva para a diabete, os tratamentos atualmente disponíveis mostram que é possível manter a qualidade de vida, mesmo com as dificuldades trazidas pela doença. "O transplante de pâncreas é, por enquanto, a única alternativa de cura para o diabete do tipo 1, que depende de insulina”, diz o cirurgião Tércio Genzini, da equipe de transplantes do Hospital Beneficência Portuguesa, de São Paulo, e de mais outros dois hospitais (p.39).

18) O transplante te $\mathrm{m} 85 \%$ de eficiência após um ano e exige medicamentos que controlem a rejeição. "Existem ainda muitos detalhes que precisam ser aperfeiçoados. Mas a técnica é bastante promissora", diz a bioquímica Mari Cleide Sogayar, do Instituto 


\begin{tabular}{|c|c|}
\hline & $\begin{array}{l}\text { de Química da USP, coordenadora das pesquisas com ilhotas realizadas em parceria com } \\
\text { o Hospital Albert Einstein, de São Paulo. "Estamos em condições de encarar esse } \\
\text { procedimento" (p.40). } \\
\text { 19) Esses novos tratamentos mostram que a vitória definitiva sobre a diabete pode estar } \\
\text { próxima. Depende do paciente fazer a sua parte. "A diabete é uma doença que exige um } \\
\text { engajamento total do paciente no cuidado de si mesmo", diz o endocrinologista e } \\
\text { psicoterapeuta Eliézer Molchansky, de Campinas, interior de São Paulo (p.43). }\end{array}$ \\
\hline $\begin{array}{l}\text { Discurso Direto seguido } \\
\text { de síntese de jornalista }\end{array}$ & $\begin{array}{l}\text { 1) "A diabete afeta os vasos sangüíneos, tanto os grandes quanto os pequenos, e, } \\
\text { conseqüentemente, todos os tecidos que são irrigados por eles", afirma o cardiologista e } \\
\text { nefrologista Celso Amodeo, presidente do Fundo de Aperfeiçoamento em Pesquisa em } \\
\text { Cardiologia, órgão da Sociedade Brasileira de Cardiologia. O excesso de açúcar no } \\
\text { sangue provoca uma modificação na estrutura do LDL-colesterol, uma proteína } \\
\text { encarregada de transportar o colesterol no sangue. Sem ser metabolizado pelo organismo, } \\
\text { esse colesterol entra com facilidade na parede dos casos sangüíneos, onde começa a } \\
\text { formar placas até obstruí-los por completo (p.21). }\end{array}$ \\
\hline $\begin{array}{c}\text { Discurso Indireto } \\
\text { Analisador de Conteúdo } \\
\text { (com modalizadores) }\end{array}$ & $\begin{array}{l}\text { 1) Apesar disso, Bjornar segue à risca o seu tratamento. Postura bem diferente têm os } \\
23 \% \text { dos diabéticos brasileiros, já diagnosticados com a doenças, que, segundo } \\
\text { estatísticas do Ministério da Saúde, não tomam os cuidados necessários para o controle } \\
\text { da glicemia (p.19). } \\
\text { 2) Segundo a Federação Internacional de Diabete, a diabete tornou-se a doença que mais } \\
\text { mata no mundo, principalmente por causa das suas complicações. } \\
\text { 3) De acordo com dados do Instituto Internacional de Diabetes, um centro australiano de } \\
\text { pesquisa ligado à Organização Mundial de Saúde, o problema afeta um em cada sete } \\
\text { adultos com mais de } 40 \text { anos de idade (p.29). }\end{array}$ \\
\hline
\end{tabular}

Em relação às duas reportagens anteriores, nesta há pouca variação nos procedimentos de transmissão do discurso citado. Temos forte presença do discurso direto preparado (19 ocorrências), apenas uma presença de discurso direto seguido de síntese de jornalista e três ocorrências de discurso indireto analisador do conteúdo com modalizadores.

Os verbos de elocução utilizados para citar o discurso são os mesmos que aparecem nas reportagens anteriores: dizer e afirmar. O primeiro prevalece sobre o segundo, já que é o mais neutro e não orienta a interpretação do leitor. Os discursos diretos são preparados, isto é, antecipa-se o conteúdo que virá. Sintaticamente, o contexto narrativo e o discurso citado parecem formar um único período, exemplificado aqui pelo uso de elementos de ligação (então, no exemplo 3) e retomadas por meio de sintagmas nominais que se referem a algo que já fora dito antes no contexto narrativo (exemplo 15).

Com isso, cria-se um diálogo entre contexto narrativo e discurso citado que parecem formar uma única voz. Entretanto, o uso das aspas define as fronteiras entre um discurso e outro. Separam-se, deste modo, o discurso da ciência e o discurso da revista, gerando uma credibilidade dada pelo discurso da ciência, que é tida como o discurso da verdade.

Em relação ao conteúdo temático, pode-se dizer que se sinaliza para uma mudança temática apontada no título da edição de novembro de 2002. Embora ainda haja muitas 
explicações científicas e, no final, apareçam formas de se curar a diabete, em muitas das falas dos especialistas e, no próprio contexto narrativo, o foco é na prevenção, na capacidade de o leitor cuidar sozinho de sua saúde, "fazer sua parte" (exemplos 14, 15 e 16).

As vozes de outras esferas da atividade aparecem em número bastante pequeno. Aparece, por exemplo, uma referência à história que inicia a reportagem (exemplo 1).

Também as vozes de instituições internacionais aparecem por meio do discurso indireto analisador do conteúdo com modalizadores, já que seria estranho colocar entre aspas a "fala" de uma instituição.

Já a ocorrência de um discurso que poderia vir naturalmente da ideologia do cotidiano, aparece na voz de um cientista:

Para os insulino-dependentes, ou seja, os portadores da diabete do tipo 1, injeções de hormônios são necessárias, sempre. No tipo 2, como o pâncreas continua a produzir insulina, injeções devem ser aplicadas apenas em casos mais extremos. "É duro conviver com a diabete, às vezes me sinto farto", afirma o norueguês Bjornar Allgot, outro dos vice-presidentes da IDF, diabético do tipo 1 há 30 anos. "Brinco com as pessoas: posso emprestar a minha diabete para você por algumas semanas?" Realmente ter férias da doença é um dos meus maiores sonhos"(p.19).

Esta fala aponta para a interpretação de que a revista quer mostrar a alta freqüência desta doença, que ataca até mesmo médicos. Somando esta fala com a mudança temática, há uma mistura de comportamentos: o médico vira paciente e o paciente deve se cuidar sozinho, por meio da prevenção.

O discurso direto sem preparação não é totalmente isolado, já que em seguida aparece uma síntese do jornalista que vem explicar com outras palavras aquilo que acabou de dizer o cientista.

A mudança temática apontada já por esta reportagem aparece explicitada no contexto narrativo. A prevenção é o foco e a revista se mostra como a conselheira, dando as dicas de como se prevenir. Entretanto, como se vê, é ainda a ciência que possui o saber em relação à saúde. $\mathrm{Na}$ verdade, ainda é ela quem dita as regras, quem oferece explicações sobre a saúde humana. A mudança temática é da própria ciência e não da revista:

Para você, que é diabético e sabe que lidar com a doença requer um esforço pessoal tremendo, a ciência encontra meios de proporcionar mais qualidade de vida e se esmera na busca tanto de tratamentos menos desgastantes quanto da cura da doença, como esta reportagem vai lhe mostrar (p.6).

Eis a palavra mágica: prevenção (p.31). 


\subsubsection{Superinteressante - novembro de 2002}

Como já se viu no título desta edição, esta reportagem aponta para uma mudança temática: trata-se agora da prevenção da saúde por parte do próprio indivíduo, sem que ele precise de médicos e de descobertas milagrosas de curas de doenças. A reportagem procura mostrar que, para ter saúde, basta se prevenir com alguns conselhos simples que a própria ciência está descobrindo e a revista divulgando. Embora o título do interior seja "Demita seu médico", a revista ainda se vale de discursos citados desses especialistas para ver quais são as atitudes que os indivíduos devem ter diante desse novo modo de lidar com a saúde. Portanto, não há propriamente um abandono da ciência, mas talvez um abandono das explicações científicas para algum fenômeno relacionado à saúde em nome de dicas simples.

Antes de passar para a análise do discurso citado, ressalto a divisão da reportagem em sub-temas (remédios, nutrição, exercícios e atitudes) cada um carregando a mesma divisão em sub-tópicos: "O que fazer?", "E se nada disso funcionar?" e "Futuro". Seguindo a tendência, quebrada apenas pela última reportagem analisada, os sub-títulos estão em forma de discurso direto substituído feito de perguntas em que se ouvem tanto a voz do jornalista quanto a voz do leitor.

São nove páginas de reportagens e 47 parágrafos. Não há nenhum boxe e também não há olho. Há, ainda, 10 fotos e 8 delas remetem ao cotidiano das pessoas. Todas elas estão situadas na parte superior das páginas.

Reproduzo os discursos citados em diferentes tabelas, de acordo com os sub-temas:

Introdução da reportagem:

\begin{tabular}{|c|l|}
\hline $\begin{array}{c}\text { Tipo de } \\
\text { discurso }\end{array}$ & \multicolumn{1}{c|}{ Reprodução } \\
\hline $\begin{array}{c}\text { Discurso } \\
\text { Direto } \\
\text { Preparado }\end{array}$ & $\begin{array}{l}\text { 1) A medicina passou por uma grande revolução na última década. Enquanto o Projeto Genoma, as } \\
\text { invenções do Prozac e do Viagra e os transplantes milagrosos preenchiam as manchetes, } \\
\text { descobertas simples e de grande impacto transformavam a maneira como os médicos tratavam os } \\
\text { problemas de saúde e tentavam evitá-los. Foi preciso que surgissem medicamentos para alguns dos } \\
\text { males que mais atacam a humanidade - hipertensão, derrame, diabete, depressão - para perceber } \\
\text { que esses problemas podem ser curados antes mesmo que apareçam, e sem precisar de remédio } \\
\text { nenhum. "Até então, os médicos esperavam a doença surgir para depois medicá-la. Hoje, os } \\
\text { profissionais da saúde estão mais preocupados em promover saúde que em eliminar a doença", } \\
\text { afirma o médico Victor Matsudo, do Centro de Estudos do Laboratório de Aptidão Física de São } \\
\text { Caetano do Sul (Celafiscs), em São Paulo. } \\
\text { 2) O que causou essa mudança? "Foi uma evolução natural da medicina", diz Michael Pratt, chefe } \\
\text { da divisão de atividade física e nutrição do centro para o Controle e Prevenção de Doenças (CDC), } \\
\text { nos Estados Unidos. }\end{array}$ \\
\hline
\end{tabular}


Tema I: Remédios

\begin{tabular}{|c|c|}
\hline Tipo de discurso & Reprodução \\
\hline $\begin{array}{l}\text { Discurso Direto } \\
\text { Preparado }\end{array}$ & 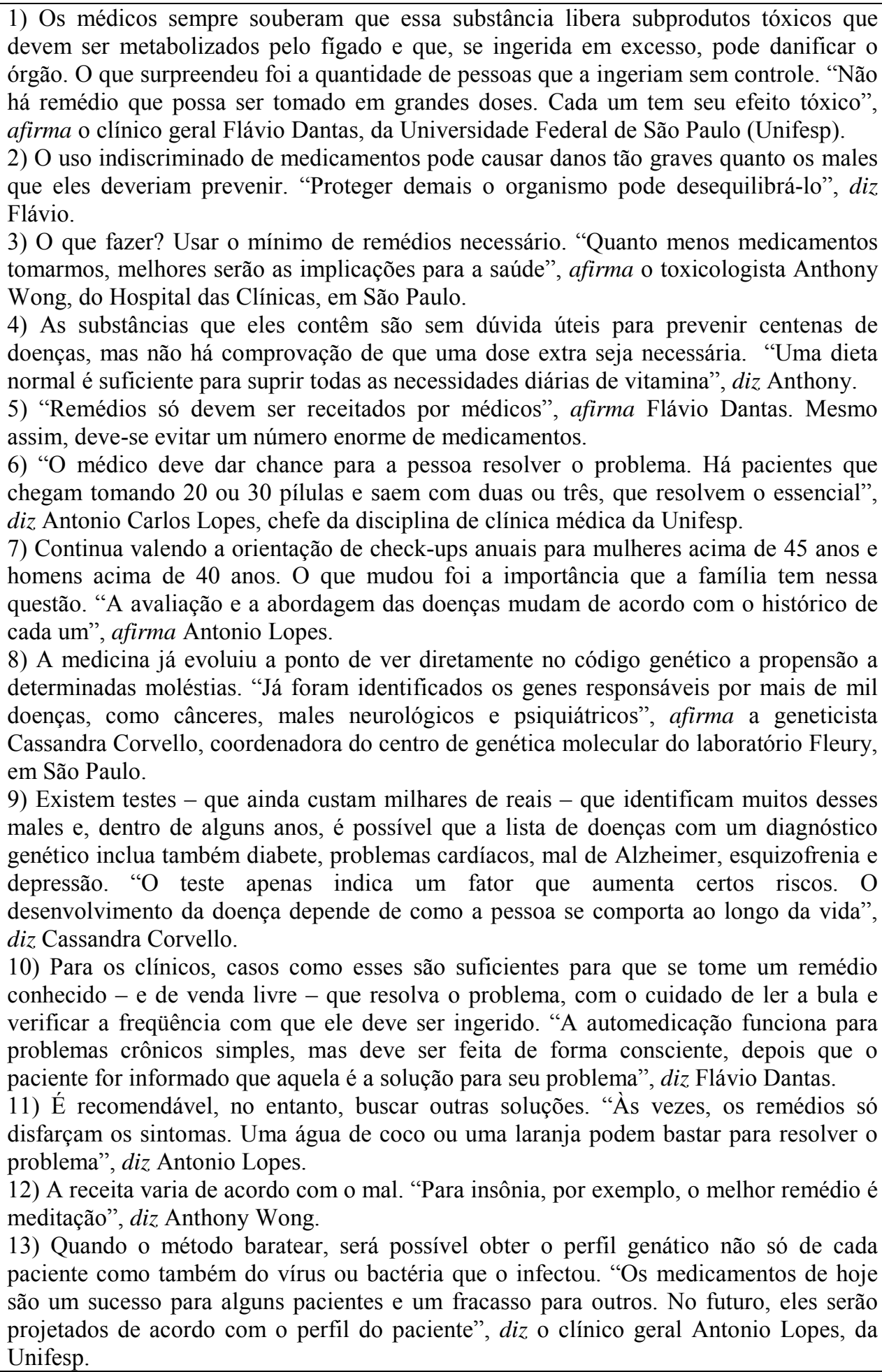 \\
\hline $\begin{array}{c}\text { Discurso Indireto } \\
\text { Analisador do conteúdo }\end{array}$ & $\begin{array}{l}\text { 1) O maior difusor dos remédios até hoje, considerado o criador da farmacologia, foi } \\
\text { Paracelso, um suíço que viveu no século XVI e que, quase sem nenhum treinamento } \\
\text { formal, afirmou que as doenças eram desequilíbrios químicos que com substâncias } \\
\text { químicas deveriam ser tratados. Ele defendia que a única forma de descobrir o tratamento }\end{array}$ \\
\hline
\end{tabular}




\begin{tabular}{|c|l|}
\hline & $\begin{array}{l}\text { correto era pela experimentação. } \\
\text { 2) Ele dizia que a diferença entre um remédio e um veneno é a quantidade que se toma. }\end{array}$ \\
\hline $\begin{array}{c}\text { Discurso Indireto } \\
\text { Analisador do conteúdo } \\
\text { (com modalizadores) }\end{array}$ & $\begin{array}{l}\text { 1) Para os clínicos, casos como esses são suficientes para que se tome um remédio } \\
\text { conhecido - e de venda livre - que resolva o problema, com o cuidado de ler a bula e } \\
\text { verificar a freqüência com que ele deve ser ingerido. }\end{array}$ \\
\hline
\end{tabular}

Tema II: Nutrição

\begin{tabular}{|c|c|}
\hline Tipo de discurso & Reprodução \\
\hline $\begin{array}{l}\text { Discurso Direto } \\
\text { Preparado }\end{array}$ & 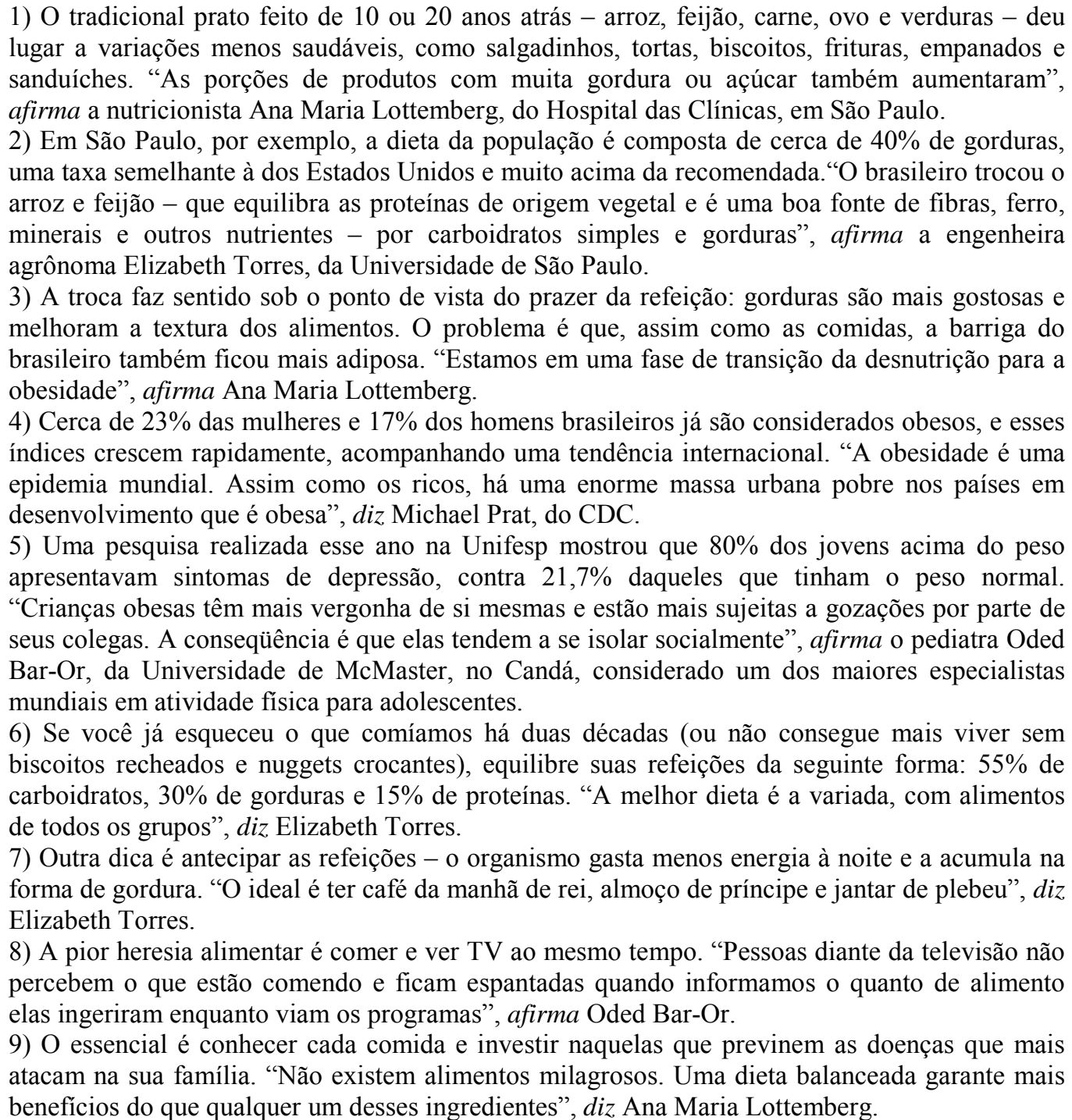 \\
\hline $\begin{array}{l}\text { Discurso Indireto } \\
\text { analisador de } \\
\text { conteúdo }\end{array}$ & $\begin{array}{l}\text { 1) A ótima notícia é que explodiram em todo mundo pesquisas que afirmam que certos } \\
\text { alimentos, além dos nutrientes, possuem substâncias especiais capazes de prevenir doenças e } \\
\text { melhorar a saúde. }\end{array}$ \\
\hline
\end{tabular}

Tema III: Exercícios 


\begin{tabular}{|c|l|}
\hline $\begin{array}{c}\text { Tipo de } \\
\text { discurso }\end{array}$ & \multicolumn{1}{|c|}{ Reprodução } \\
\hline $\begin{array}{c}\text { Discurso } \\
\text { Direto } \\
\text { Preparado }\end{array}$ & $\begin{array}{l}\text { 1) Um estudo coordenado por Michael Pratt mostrou que as doenças causadas pelo sedentarismo } \\
\text { consomem por ano } 76 \text { bilhões de dólares, o equivalente a 70\% dos gastos hospitalares mundiais. "O } \\
\text { prejuízo que a falta de atividade física traz para o Brasil é semelhante ao encontrado nos países } \\
\text { desenvolvidos", diz Pratt. } \\
\text { 2) O sedentarismo só não mata mais do que o cigarro - quem fuma, mas se exercita, tem a mesma } \\
\text { chance de ter doenças crônicas que um não-fumante que fica parado dentro de casa. "A diferença é }\end{array}$ \\
que o número de pessoas que não fazem atividade física é muito maior que o de fumantes, o que \\
torna o sedentarismo a maior epidemia do mundo", afirma Victor Matsudo, do Celafiscs. \\
3) Há também o perigo de doenças mentais. "Além de causar depressão, descobriu-se que o \\
sedentarismo aumenta a probabilidade de a pessoa cometer suicídio", diz Victor Matsudo.
\end{tabular}

\section{Tema IV: Atitude}

\section{Tipo de discurso \\ Discurso Direto \\ Preparado}

Reprodução

1) O excesso de corticóides, por sua vez, destrói células do cérebro (em especial do hipocampo, a região associada à formação de memória) e enfraquece o sistema imunológico, reduzindo a resistência a infecções. "O estresse constante aumenta a probabilidade de problemas crônicos e infecciosos", diz o psicobiólogo José Roberto leite, da Unifesp.

2) Na maioria das vezes, os estímulos emocionais, mais do que as pressões objetivas do dia-a-dia, são os responsáveis pelos problemas de saúde. "Um chefe arbitrário é mais perigoso do que uma navalha na mão de uma criança", diz Antonio Carlos Lopes.

3) O problema do estresse psicológico é que uma emoção negativa gera no cérebro uma resposta distorcida. A solução, portanto, é mudar a forma de interpretar as adversidades. "Quando você percebe que o problema não é tão ruim, ele deixa de ser estressante", diz José Roberto.

4) Defina o que a faz tão ruim e compare com as situações de outras pessoas - salvo raras exceções, os outros terão dilemas semelhantes. "O essencial é racionalizar a 


\begin{tabular}{|c|l|}
\hline & preocupação e se concentrar apenas nos problemas que valem a pena", diz José Roberto \\
Leite. "Na hora de agir, estabeleça metas, evite exageros e planeje com cuidado o que \\
fazer". \\
5) Além disso, respire mais pelo diafragma, logo acima da barriga, do que pelo tórax. "A \\
respiração torácica é muito rápida e não elimina corretamente o gás carbônico", diz \\
Flávio Dantas. \\
6) Se toda a análise e planejamento do mundo não foram suficiente para eliminar o \\
estresse, talvez seja hora de tomar atitudes mais drásticas. "Para todo problema existe um \\
elenco enorme de opções; a questão é escolher qual. Se o ambiente de trabalho é ruim, \\
analise se a melhor opção é agüentar quieto ou simplesmente ir embora dali", diz Flávio \\
Dantas.
\end{tabular}

De todas as reportagens analisadas até o momento, esta é a que apresentou o maior número de ocorrências de discurso direto preparado. Trata-se de 43 aparições deste procedimento de transmissão do discurso alheio. Se o tema central da reportagem é a prevenção da saúde por parte do próprio indivíduo, isso não quer dizer que a ciência deixa de ter voz. Pelo contrário, as descobertas desse novo jeito de ser da medicina provêm da própria ciência e não da ideologia do cotidiano ou do discurso jornalístico. Assim, a voz que ainda tem autoridade, que ainda possui um saber que o leitor não tem, é a ciência. Isso se torna evidente pelo grande número de citações em discurso direto preparado cujos autores são os cientistas.

Seguindo a tendência do período, não há aqui nenhuma variedade nos verbos de elocução. Aparecem apenas dizer e afirmar. O primeiro é neutro, não traz qualquer condicionamento de interpretação. O segundo, embora seja um pouco mais carregado de sentido, não se compara a outros que foram utilizados nas reportagens dos outros períodos como confessar, assegurar, insistir, desafiar, garantir. O verbo afirmar traz em sua semântica dizer ou declarar com firmeza. Assim, isso traz segurança ao leitor que vai acreditar com mais facilidade nas falas dos especialistas. 
Em relação aos autores aos quais os discursos citados são atribuídos, temos, igualmente às reportagens do segundo período, uma grande variedade de especialistas, incluindo aí vários especialistas de outros países, mostrando a pesquisa da revista para realizar esta reportagem. A presença de especialistas estrangeiros também serve para dar maior credibilidade às falas, uma vez que se acredita, na ideologia do cotidiano, que, em países desenvolvidos, realizam-se pesquisas de ponta.

Os discursos diretos preparados dialogam com o contexto narrativo, contribuindo na mensagem que a reportagem quer passar ao leitor: a de que cuidar da saúde virou tarefa do próprio indivíduo, pois tudo o que é necessário para ter uma vida saudável está ao alcance dele: os remédios viraram alimentos, as atividades físicas dispensam academia e esforço já que podem ser feitas em qualquer lugar e para evitar o estresse basta não se concentrar nos problemas que não valem a pena.

É importante ressaltar que o discurso da ideologia do cotidiano se faz presente não só na divisão das partes que compõem a reportagem (os sub-títulos) como também na presença de discurso direto substituído. Assim, o leitor se sente "incluído" na reportagem já que se identifica com as perguntas. Entretanto, essas perguntas, além de captarem o indivíduo para a leitura, contribuem para a relação assimétrica presente na prática discursiva deste tipo de divulgação científica. Enquanto o leitor tem perguntas, o jornalista tem as repostas porque é ele quem detém as informações científicas. Às vezes, é o próprio cientista que responde a essas perguntas, já que ele é o que tem não as informações científicas, mas o próprio conhecimento científico. Assim, ora é o jornalista (exemplo 1) ora é o cientista (exemplo 2) que responde às perguntas, simulando um diálogo:

1)O que fazer? Usar o mínimo de remédios necessário. "Quanto menos medicamentos tomarmos, melhores serão as implicações para a saúde", afirma o toxicologista Anthony Wong, do Hospital das Clínicas, em São Paulo.

2)O que é saúde? "É o completo bem-estar físico,mental e social", afirma Antonio Carlos Lopes, da Unifesp. "Então, por definição, quem ganha salário mínimo não tem saúde", diz.

No primeiro exemplo, embora seja primeiramente a voz do jornalista que apareça dando a resposta, ela teve de ser legitimada pela voz de um cientista, comprovando que as informações divulgadas pela revista são amplamente apoiadas em discursos de cientistas, o que confere credibilidade à informação.

As pequenas aparições de discurso indireto analisador do conteúdo não introduzem fala de especialistas, mas de entidades, como, por exemplo, pesquisas (exemplo 3). Além delas, um 
autor cujo discurso citado indireto foi atribuído era do século XVI (os dois primeiros exemplos abaixo). Causaria estranheza aproximar tanto sua fala da oralidade através do discurso direto:

1) O maior difusor dos remédios até hoje, considerado o criador da farmacologia, foi Paracelso, um suíço que viveu no século XVI e que, quase sem nenhum treinamento formal, afirmou que as doenças eram desequilíbrios químicos que com substâncias químicas deveriam ser tratados. Ele defendia que a única forma de descobrir o tratamento correto era pela experimentação.

2) Ele dizia que a diferença entre um remédio e um veneno é a quantidade que se toma.

3) A ótima notícia é que explodiram em todo mundo pesquisas que afirmam que certos alimentos, além dos nutrientes, possuem substâncias especiais capazes de prevenir doenças e melhorar a saúde.

\section{Nas duas ocorrências de discurso indireto analisador de conteúdo com modalizadores,}

há a tendência das outras edições analisadas em que, na maior parte dos casos, o autor atribuído ao discurso não é uma pessoa, mas uma entidade (primeiro exemplo) ou um grupo de cientistas, o que nos leva à interpretação de que o discurso citado é comum a muitos especialistas (segundo exemplo):

1) Para a medicina de hoje, o trabalho, a família e a vizinhança são tão importantes quanto o funcionamento de órgãos e hormônios.

1) Para os clínicos, casos como esses são suficientes para que se tome um remédio conhecido - e de venda livre que resolva o problema, com o cuidado de ler a bula e verificar a freqüência com que ele deve ser ingerido.

Essas ocorrências mostram a preferência ao discurso direto quando se quer dar voz a um especialista, quando se quer legitimar essa fala, quando se quer aproximá-la da realidade. O efeito do discurso direto é justamente esse de fazer o leitor pensar que aquelas falas realmente foram proferidas, saíram da boca do especialista e não da boca dos jornalistas e da revista já que a eles ainda falta autoridade para proferir tais falas.

\subsubsection{Superinteressante - fevereiro de 2003}

Esta reportagem evidencia a mudança temática iniciada nas duas reportagens anteriores por questionar a necessidade dos remédios e, conseqüentemente, da medicina e suas descobertas científicas. Segundo a reportagem, podemos nos proteger e nos medicar com os próprios alimentos que estão ao nosso alcance. A reportagem trata, ainda, da automedicação indiscriminada que vem crescendo entre as pessoas. Esse alto consumo de remédios está aliado às fortes propagandas dos laboratórios comerciais.

Em relação à forma composicional, esta reportagem de 8 páginas divide-se em 32 parágrafos que estão sub-divididos da seguinte maneira: introdução (par.1-6); "Overdose de lucros" (par.7-9); "Conflito de interesses" (par.10-19); "Cerco médico" (par.20-26); "Evitando a dependência" (par.27-32). Diferenciando-se das demais reportagens do período, não há nenhum 
sub-título em forma de perguntas. Há a presença de olhos nesta reportagem que servem para "quebrar" a página repleta de parágrafos e letras pequenas. Com os olhos, há uma mudança na fonte e uma repetição de algo que foi falado no texto, conferindo um exercício de retomada de informações consideradas importantes pelo contexto narrativo. Quatro fotos de remédios em lugares inusitados aparecem na reportagem: em uma, os remédios estão em uma balança; na outra, os remédios compõem os botões de uma calculadora; na terceira, contribuindo para a imagem da capa, os remédios estão dentro de um prato; por fim, há uma caixinha dividida em quatro partes - almoço, manhã, jantar, noite - e, em cada uma dessas partes, há pílulas de remédios. Dois dos três boxes que aparecem são destinados a uma visualização de dados ("Mercado de elite" e "Campeões de venda nas farmácias"). O outro boxe traz um depoimento de uma mulher comum, configurando um grande discurso direto que vem da ideologia do cotidiano, "Eu não conseguia parar de tomar".

Além desse, os discursos citados que compõem a reportagem estão reproduzidos na tabela a seguir:

\begin{tabular}{|c|c|}
\hline Tipo de discurso & Reprodução \\
\hline $\begin{array}{l}\text { Discurso Direto } \\
\text { Preparado }\end{array}$ & $\begin{array}{l}\text { 1) Esteja certo: se um químico fizesse uma análise fria das substâncias encontradas na } \\
\text { sua gaveta e na do seu filho, o garoto não seria o único a precisar de uma conversa séria } \\
\text { sobre o perigo de se amparar em muletas psicoativas. "Do ponto de vista científico, não } \\
\text { há diferença entre um dependente de cocaína e um viciado em remédios que contêm } \\
\text { anfetamina", diz o psiquiatra Dartiu Xavier da Silveira, coordenador do Programa de } \\
\text { Orientação e Assistência a Dependentes (Proad), da Universidade Federal de São Paulo. } \\
\text { "Droga é droga, não importa se ela foi comprada num morro ou numa farmácia dentro } \\
\text { de um shopping". } \\
\text { 2) O resultado é alarmante: segundo dados do Sistema Nacional de Informações Tóxico- } \\
\text { Farmacológicas (Sinitox), o Brasil teve } 22121 \text { casos de intoxicação, no ano } 2000 \text {, } \\
\text { provocados pelo uso indevido de remédios, quase um terço de todos os casos } \\
\text { registrados. "E isso é só a ponta do iceberg", diz Rosany Bochner, coordenadora da } \\
\text { instituição. "Como não recebemos informações de todos os estados e nem sempre os } \\
\text { médicos assumem os erros de prescrição, esse número deve ser pelo menos quatro vezes } \\
\text { maior". } \\
\text { 3) Com dados tão alarmantes, você deve estar se perguntando por que a população de lá } \\
\text { não pressiona o seu governo a usar parte da fortuna no combate à drogas ilegais (no ano } \\
\text { de } 2000 \text {, foram } 39 \text { bilhões de dólares) em campanhas de prevenção de intoxicação por } \\
\text { medicamentos. Boa pergunta. "É que a gravidade desses dados termina sendo mascarada } \\
\text { nas estatísticas", diz a coordenadora do Sinitox. } \\
\text { 4) Ela explica que as pesquisas norte-americanas, por exemplo, classificam os casos de } \\
\text { intoxicação por tipo de medicamento, separando analgésicos de antidepressivos e assim } \\
\text { por diante. "Somados, os medicamentos também são a maior causa de intoxicação por } \\
\text { lá", diz Rosany. "Mas, devido a essa classificação, são os produtos de limpeza que } \\
\text { aparecem como vilões em primeiro lugar, já que são agrupados numa única categoria". } \\
\text { 5) Sem consumidores com bom poder aquisitivo, os laboratórios não se interessam em } \\
\text { fabricar remédios baratos ou voltados para as doenças de países pobres. "Para essas } \\
\text { multinacionais, é mais lucrativo medicamentos para doenças crônicas como o diabete ou }\end{array}$ \\
\hline
\end{tabular}


problemas cardíacos, uma vez que o paciente vai precisar continuar consumindo o remédio até o fim da vida", diz a química Eloan Pinheiro, diretora do laboratório Farmanguinhos, da Fundação Oswaldo Cruz, que produz medicamentos que estão ajudando o governo brasileiro a ser auto-suficiente - e um modelo para o mundo - no combate à AIDS.

6) Há quem afirme que o preço pago pelos centros de pesquisa por esse tipo de parceria pode ter sido alto demais. "Os patrocinadores decidem quem vai trabalhar no estudo e excluem quem tem pontos de vista conflitantes com os seus interesses", afirma Steven Cummings, diretor do programa de pesquisa clínica da Universidade da Califórnia, em São Francisco.

7) São comuns também a imposição de cláusulas de confidencialidade que impedem a divulgação de resultados e o intercâmbio de dados entre cientistas, duas restrições quase fatais para a produção de conhecimento científico. "A ciência depende de um fluxo aberto e livre de informação", diz o pesquisador Steven Rosenberg, do Instituto Nacional do Câncer dos Estados Unidos. "No entanto, quanto mais a pesquisa é sustentada por companhias privadas, mais a ética dos negócios atropela a ética da ciência".

8) A equipe foi convidada a refazer seu relatório sucessivamente até que, quando chegaram à mesma conclusão pela décima vez, os próprios cientistas desistiram da pesquisa. "Não conseguimos nenhum resultado, mas é preciso ter princípios", afirma Furberg.

9) O que diz de tudo isso a indústria farmacêutica? "Quando realiza uma pesquisa, a indústria investe alto e não é justo que a divulgação dos dados beneficie os concorrentes", diz o biólogo Ciro Mortella, presidente da Federação Brasileira da Indústria Farmacêutica (Febrafarma). "Os laboratórios são empresas que precisam apresentar resultados a seus acionistas. Não somos monges, mas somos éticos".

10) Resultado: apenas um terço das 400 milhões de caixas de remédio vendidas por ano no Brasil veio de prescrições médicas. "Em outros países, como nos Estados Unidos, há um controle mais rígido na farmácia entre os chamados remédios leves e os que requerem receita médica", diz Rosany Bochner, coordenadora do Sinitox. "Mas esse controle não é suficiente, uma vez que essas drogas leves não são tão leves, principalmente quando não se limita a quantidade da compra".

11) Esse tipo de cerco aos médicos tornou-se tão incômodo que algumas clínicas, como a Everett, de Washington, decidiram não mais receber esses representantes dos laboratórios, a fim de preservar a liberdade de prescrição da sua equipe. "Os médicos estão cada vez mais ocupados e quase não têm tempo para ler sobre as novas drogas", diz o pesquisador Stephen Soumerai, da Universidade de Harvard. "Com isso, a influência da propaganda feita pelos representantes da indústria farmacêutica torna-se quase incontrolável”.

12) Segundo Ciro Mortella, atual presidente da entidade, essas acusações não são de médicos, mas de políticos em busca de promoção pessoal. "É ridículo imaginar que, após sete anos de estudo, um médico se comporte como um mentecapto e se deixe manipular como uma criança", afirma Ciro.

13) Mesmo reconhecendo que uma série de doenças são de fundo psicológico (as chamadas doenças psicossomáticas), boa parte dos médicos vêem no momento da prescrição uma forma prática e segura de abreviar a consulta. "À medida que o médico tem menos tempo e disponibilidade para conversar e se dedicar aos seus pacientes, mais propenso fica a receitar medicamentos", diz o psiquiatra e psicanalista José Atílio Bombana, da Unifesp. "Ele abre mão da sua grande arma terapêutica, que é o contato com o paciente, e adota como única resposta a medicação, o que, naturalmente, estimula a utilização de remédios".

14) Ele diz que os dois casos mais comuns de dependência estão ligados aos benzodiazepínicos (calmantes) e às anfetaminas (usadas como moderadores de apetite). "Quando os comprimidos acabam, os dependentes têm tremores, taquicardia e, no caso dos dependentes de anfetamina, até surtos psicóticos", diz o psiquiatra.

15) Cerca de 5\% dos casos de pacientes atendidos em clínicas e hospitais se enquadram nessa classificação, sem falar no fato de que mais de $80 \%$ dos diagnósticos médicos se 


\begin{tabular}{|c|c|}
\hline & $\begin{array}{l}\text { resumem à sigla DNV (distúrbio neurovetativo), a crise hiponcondríaca que atinge as } \\
\text { pessoas comuns, a agitação da vida moderna. "A hipocondria é um dos recursos do } \\
\text { homem para lidar com as dores do drama de sua existência", diz o psicólogo Rubens } \\
\text { Volich em seu livro Hipocondria: Impasses da Alma, Desafios do Corpo. } \\
\text { 16) "A maioria dos hipocondríacos sofre de depressão", diz o psiquiatra Marcelo Niel. } \\
\text { "E, enquanto esse problema não for tratado, eles continuarão expostos a medicamentos } \\
\text { desnecessários". } \\
\text { 17) Ele diz que considera normal que alguém tome um calmante em momento } \\
\text { especialmente insuportável. "O problema é quando qualquer situação de desconforto } \\
\text { passa a ser esse momento crítico", diz o psiquiatra. } \\
\text { 18) A maioria dos especialistas parece concordar num ponto de que pouca gente se dá } \\
\text { conta: a maior parte das doenças pode ser curada pela ação do próprio organismo. "A } \\
\text { natureza resolve sozinha } 90 \% \text { dos problemas de saúde", diz o médico Daniel Sigulem, } \\
\text { professor da Universidade Federal de São Paulo. "Em geral, pede-se aos médicos apenas } \\
\text { que não atrapalhem". }\end{array}$ \\
\hline $\begin{array}{l}\text { Discurso Direto seguido } \\
\text { de síntese de jornalista }\end{array}$ & $\begin{array}{l}\text { 1) "Todo remédio tem efeitos colaterais", afirma Arnaldo Lichenstein, clínico-geral do } \\
\text { Hospital das Clínicas, em São Paulo. Os antialérgicos causam sonolência e dificuldade } \\
\text { de concentração. Os antibióticos prejudicam rins e fígado e até podem causar surdez. }\end{array}$ \\
\hline $\begin{array}{l}\text { Discurso Indireto } \\
\text { Analisador de Conteúdo } \\
\text { (com verbos de elocução) }\end{array}$ & $\begin{array}{l}\text { 1) Ela explica que as pesquisas norte-americanas, por exemplo, classificam os casos de } \\
\text { intoxicação por tipo de medicamento, separando analgésicos de antidepressivos e assim } \\
\text { por diante. } \\
\text { 2) Há quem afirme que o preço pago pelos centros de pesquisa por esse tipo de parceria } \\
\text { pode ter sido alto demais. } \\
\text { 3) Na época, José Eduardo Bandeira de Melo, representante da então Abifarma (atual } \\
\text { Febrafarma), rebateu essa afirmação e colocou a culpa nos médicos, dizendo que eram } \\
\text { eles que exigiam favores da indústria, ameaçando até não mais receitarem seus produtos } \\
\text { caso não recebessem passagens aéreas ou o pagamento desses cursos e encontros. }\end{array}$ \\
\hline $\begin{array}{l}\text { Discurso Indireto } \\
\text { Analisador de Conteúdo } \\
\text { (com modalizadores) }\end{array}$ & $\begin{array}{l}\text { 1) Segundo uma estimativa da revista inglesa Focus, o setor teria faturado, no ano } \\
\text { passado, } 406 \text { bilhões de dólares. } \\
\text { 2) Segundo ele, o patrocínio de eventos e o pagamento de passagens para médicos teriam } \\
\text { criado uma situação de dependência que, em alguns casos, praticamente havia } \\
\text { transformado os congressos em encontros propagandísticos dos laboratórios. }\end{array}$ \\
\hline $\begin{array}{l}\text { Discurso Direto } \\
\text { Substituído }\end{array}$ & $\begin{array}{l}\text { 1) Afinal, precisamos mesmo de tantos remédios? Segundo a maioria dos especialistas, a } \\
\text { resposta é não. } \\
\text { 2) O que diz de tudo isso a indústria farmacêutica? "Quando realiza uma pesquisa, a } \\
\text { indústria investe alto e não é justo que a divulgação dos dados beneficie os } \\
\text { concorrentes", diz o biólogo Ciro Mortella, presidente da Federação Brasileira da } \\
\text { Indústria Farmacêutica (Febrafarma). "Os laboratórios são empresas que precisam } \\
\text { apresentar resultados a seus acionistas. Não somos monges, mas somos éticos". } \\
\text { 3) Mas como saber quem é viciado e quem não é? Marcelo diz que as pessoas devem } \\
\text { ficar alertas quando sentirem que estão condicionando vários momentos da vida ao uso } \\
\text { de algum medicamento(p.30) }\end{array}$ \\
\hline
\end{tabular}

Nas dezoito ocorrências de discurso direto preparado, aparecem somente os seguintes verbos de elocução: dizer e afirmar. Igualmente à análise da edição anterior, enquanto o verbo dizer não carrega nenhuma carga semântica que induza a alguma interpretação, o verbo afirmar significa que a pessoa enunciou com firmeza, com segurança. Também como nas edições anteriormente analisadas, as indicações do autor a quem é atribuída a fala, vão do nome completo, passando pela especialidade até a instituição de origem. 
Antes de os discursos aparecerem, há uma antecipação do assunto que virá. Isso é claramente evidenciado quando há presença de anáforas nas falas citadas (exemplo 2).

O fato de o discurso citado ser preparado mostra o grande diálogo que existe entre este e o contexto narrativo em que este discurso é inserido. Como afirma Bakhtin, o contexto narrativo avoluma o discurso citado à sua maneira, dando a ele novas significações. Nestes casos, o contexto narrativo se vale de discursos citados que confirmem a tese que a reportagem quer defender: as pessoas consomem remédios de maneira incorreta.

Nas ocorrências de discurso indireto analisador do conteúdo, continuamos a ter cientistas como os autores dos discursos, mas aparecem também a voz de outra esfera, a esfera da indústria farmacêutica (exemplo 3).

Como nas outras edições, a presença de discurso indireto analisador do conteúdo com modalizadores é a forma preferida quando se quer atribuir o discurso citado a uma instituição (Segundo uma estimativa da revista inglesa Focus).

Há uma presença de discurso direto sem preparação que possui, logo após sua aparição, uma explicação do jornalista. Este tipo de discurso confere cumplicidade entre jornalista e leitor, uma vez que, caso o leitor não entenda essa aparição abrupta do discurso do cientista, lá estará o discurso do jornalista para socorrê-lo, explicando ou, como é o caso da ocorrência nesta reportagem, exemplificando.

Seguindo a forte tendência, já iniciada no segundo período, há três ocorrências de discurso direto preparado, em que mais uma vez o jornalista torna-se cúmplice do leitor. É como se o jornalista fizesse dois "favores" ao leitor: o primeiro, imaginar as perguntas que o leitor poderia se fazer e o segundo, ir buscar as respostas na esfera da ciência para mostrá-las ao leitor.

6.2.6 Superinteressante - outubro de 2003

Esta reportagem possui 10 páginas, mas 5 delas são inteiramente formadas por fotos da mesma mulher da capa meditando. Na primeira foto, não há nada escrito. Nas outras 4 há pequenos comentários substituindo os olhos que não aparecem no meio desta reportagem. São 33 parágrafos divididos da seguinte maneira: introdução (par.1-14); "Biologia do zen" (par.15-21); "Mente quieta, corpo saudável" (par.22-26); "O cérebro reprogramado" (par.27-30); "Fast-food mental?" (par.31-33). Há, ainda, dois boxes: "Passo a passo" e "Entre o céu e os neurônios". 
A técnica da meditação é exposta nesta reportagem como uma atividade já recomendada pelos médicos, mas ainda não pertencente à medicina. Há vozes, concretizadas pelo discurso direto, que não acreditam no poder de tal prática. Essas vozes, como se verá, vão causar uma polifonia em relação ao próprio tema que este período vem divulgando: a prevenção.

Vejamos os discursos citados da última reportagem:

\begin{tabular}{|c|c|}
\hline Tipos de Discurso & Reprodução \\
\hline $\begin{array}{l}\text { Discurso Direto } \\
\text { Preparado }\end{array}$ & 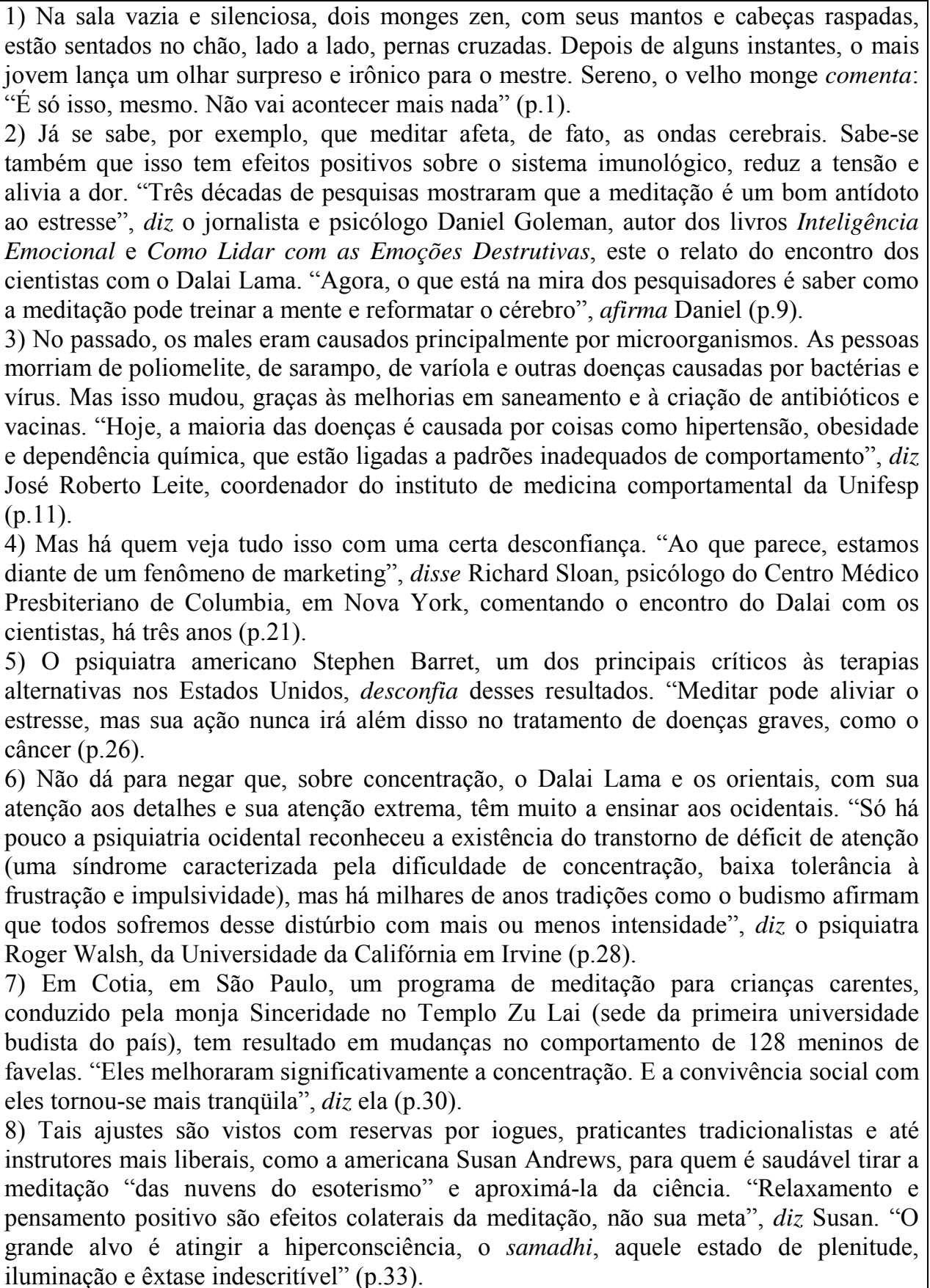 \\
\hline
\end{tabular}




\begin{tabular}{|c|c|}
\hline $\begin{array}{l}\text { Discurso Indireto } \\
\text { Analisador da Expressão }\end{array}$ & $\begin{array}{l}\text { 1) Nos anos } 70 \text {, quando a prática começou a se espalhar pelo Ocidente, impulsionada } \\
\text { pelo movimento hippie, o cantor e compositor brasileiro Walter Franco cantava que tudo } \\
\text { era uma questão de "manter a mente quieta, a espinha ereta e o coração tranqüilo" (p.10). }\end{array}$ \\
\hline $\begin{array}{l}\text { Discurso Indireto } \\
\text { Analisador do Conteúdo } \\
\text { (com modalizadores) }\end{array}$ & $\begin{array}{l}\text { 1) Segundo Richard, é discutível se o impacto da meditação sobre o sistema nervoso e a } \\
\text { saúde tem um efeito profundo e duradouro ou apenas superficial e efêmero (p.21). } \\
\text { 2) O desempenho antiestresse da meditação, segundo estudos das universidades } \\
\text { americanas Stanford e Columbia, acontece porque a mente aquietada inibe a produção de } \\
\text { adrenalina e cortisol - hormônios secretados nas situações de estresse -, ao mesmo } \\
\text { tempo que estimula no cérebro a produção de endorfinas, um tranqüilizante e analgésico } \\
\text { tão poderoso quanto a morfina e responsável pela sensação de leveza nos momentos de } \\
\text { alegria (p.24). } \\
\text { 3) Para ele, a saúde e a longevidade no mundo serão, cada vez mais, resultado de um } \\
\text { tripé formado por remédios, cirurgias e cuidados pessoais, incluindo-se aqui a meditação } \\
\text { e todo o poder catalisador das crenças nas reações orgânicas (p.26). } \\
\text { 4) Segundo ele, esse é o tempo que os americanos estão acostumados a se concentrar } \\
\text { diariamente: os blocos de programas de TV duram exatamente isso, entre um comercial e } \\
\text { outro (p.32). }\end{array}$ \\
\hline $\begin{array}{l}\text { Discurso Direto } \\
\text { Substituído }\end{array}$ & $\begin{array}{l}\text { 1) Quer dizer que meditar é só parar e não pensar em nada? É (p.4). } \\
\text { 2) Mas como é que algo assim, na contramão do pragmatismo moderno, consegue } \\
\text { empolgar tanta gente? Como pode haver gente capaz de pagar caro para participar de } \\
\text { sessões de meditação - ou seja, para ficar sentado em silêncio em uma sala quase sem } \\
\text { móveis? (p.6). } \\
\text { 3) Mas, afinal, como é que se medita e o que acontece durante a prática contemplativa? } \\
\text { Bem, há um leque de modalidades para quem deseja meditar, mas a receita básica é a } \\
\text { mesma: concentração (p.13). } \\
\text { 4) Mas como saber se deu certo? Como saber se você meditou? Essa é a melhor parte da } \\
\text { história: não há nota ou avaliação (p.14). } \\
\text { 5) A meditação ajuda a controlar a ansiedade e a aliviar a dor? Ao que tudo indica, sim } \\
\text { (p.22). }\end{array}$ \\
\hline
\end{tabular}

Como em todas as outras reportagens do período, o discurso direto preparado é o que prevalece, com oito ocorrências. Os únicos verbos de elocução que causam estranheza nestas ocorrências são justamente aqueles que foram proferidos por uma pessoa não pertencente à esfera da ciência (exemplo 1) e por uma pessoa que pertence à esfera da ciência, mas discorda da maioria dos cientistas que aparecem na reportagem recomendando a prática da meditação (exemplo 5). Ao usar o verbo desconfiar, a voz da revista orienta a interpretação do leitor, fazendo-o considerar o cientista que proferiu o discurso como alguém que não pode ainda afirmar algo pois, por enquanto, está na plano das opiniões.

A presença de discurso indireto analisador da expressão foi a forma preferida, em todas as reportagens de todos os períodos, para proferir um discurso proveniente de outra esfera da atividade humana. Neste caso, à esfera da arte:

Nos anos 70, quando a prática começou a se espalhar pelo Ocidente, impulsionada pelo movimento hippie, o cantor e compositor brasileiro Walter Franco cantava que tudo era uma questão de "manter a mente quieta, a espinha ereta e o coração tranqüilo" (p.10). 
Esta forma de citar distancia o contexto narrativo não tanto sintaticamente, mas semanticamente. As palavras colocadas entre aspas são "estranhas" e possuem outras "cores" em relação ao contexto narrativo que pretende se assemelhar ao discurso da esfera da ciência.

A utilização de discurso indireto analisador do conteúdo com modalizadores segue a tendência de se distanciar do discurso citado, marcando bem as fronteiras entre um e outro. Dois dos quatro discursos citados nesta forma são vozes divergentes da grande maioria dos discursos citados que defendem e mostram os benefícios trazidos pela meditação:

1) Segundo Richard, é discutível se o impacto da meditação sobre o sistema nervoso e a saúde tem um efeito profundo e duradouro ou apenas superficial e efềmero (p.21).

2) Para ele, a saúde e a longevidade no mundo serão, cada vez mais, resultado de um tripé formado por remédios, cirurgias e cuidados pessoais, incluindo-se aqui a meditação e todo o poder catalisador das crenças nas reações orgânicas (p.26).

O segundo exemplo mostra que, apesar de os indivíduos poderem agora se prevenir por meio de hábitos saudáveis, há ainda uma dependência dos remédios e das cirurgias que foram negadas nas últimas reportagens. Isso causa uma polifonia não só dentro dessa reportagem, como também uma polifonia entre reportagens desse mesmo período.

Das 6 reportagens que compõem o período, somente uma (setembro de 2002) não apresentou discurso direto substituído. As demais utilizaram essa forma, o que acabou sendo uma das características deste período. Aqui, a presença deste tipo de discurso gera o mesmo efeito que nas outras: o de se conseguir "ouvir" a voz do leitor dentro da reportagem. Ele "faz" uma pergunta e ou a ciência ou o jornalista responde. No caso desta edição, o contexto narrativo se encarrega de responder:

1) Mas, afinal, como é que se medita e o que acontece durante a prática contemplativa? Bem, há um leque de modalidades para quem deseja meditar, mas a receita básica é a mesma: concentração (p.13).

2) A meditação ajuda a controlar a ansiedade e a aliviar a dor? Ao que tudo indica, sim (p.22).

Passemos agora para a síntese do discurso citado no terceiro período.

\subsubsection{Síntese do discurso citado no terceiro período}

Vejamos agora as características do discurso citado neste período:

1) o discurso direto preparado predomina enquanto procedimento de transmissão de discurso alheio. Esse tipo oferece uma clara mudança de entonações, por meio do recurso das aspas, isolando semanticamente o discurso do autor. Antecipa-se o conteúdo que virá na fala e, depois 
que a fala é proferida, identifica-se o autor por meio do nome/instituição de origem/especialidade, conferindo à fala citada um acento valorativo positivo;

2) o discurso indireto analisador da expressão aparece nesse período confirmando a tendência dos outros de que essa é a forma preferida para citar discursos da ideologia do cotidiano e de outras esferas (a da religião, a da política, etc.);

3) presença de discurso direto substituído como forma de aproximar o leitor da reportagem, reproduzindo suas possíveis dúvidas, e como forma de simular um diálogo convencional, já que as perguntas são respondidas, ora pelo jornalista, ora pelo cientista;

4) discurso direto seguido de síntese do jornalista como uma variante dos procedimentos de transmissão da fala alheia. Embora não haja preparação, há uma explicação ou exemplificação do jornalista logo após a fala do cientista. A outra "moldura" é, por vezes, algum dos sub-títulos da reportagem;

5) pouca variação de verbos de elocução. Predominância de dizer e afirmar que não carregam condicionamento de interpretação;

6) articulação composicional construída com base nas dúvidas do leitor e não como um desenrolar do assunto, como acontecia nos outros períodos;

7) mudança temática: tanto o contexto narrativo quanto a fala dos cientistas funcionam como conselhos ou argumentos que pretendem convencer o leitor a adotar tal hábito para preservar a saúde. Há uma modificação de um fazer-saber para fazer-fazer. 


\section{Considerações finais}

Quando Bakhtin afirma que gênero do discurso é um enunciado estável do ponto de vista do conteúdo temático, do estilo e da forma composicional, percebemos que, de fato, o gênero reportagem de capa de uma revista comercial como a Superinteressante se vale de certos procedimentos comuns ao longo dos três períodos analisados. Entretanto, devido às coerções e condições impostas pela esfera do jornalismo comercial, no qual este gênero está inserido, algumas modificações foram encontradas. Como se trata de divulgação da ciência na esfera do jornalismo comercial, a finalidade desse gênero é não só fazer o leitor saber algo, como também fidelizá-lo como consumidor freqüente da revista.

Com base, sobretudo, no outro a quem o gênero analisado foi endereçado é que podemos afirmar como o estilo, a forma composicional e o tema foram construídos. Esse outro pertence à ideologia do cotidiano e é por isso que ela tanto apareceu, juntamente à esfera da ciência. $\mathrm{O}$ estilo e a forma de se compor esse gênero foram, ao longo dos períodos, estreitando o diálogo com esse leitor.

Assim, percebemos que essa captação do leitor, nos títulos, vai se intensificando ao longo dos períodos analisados. No primeiro deles, essas marcas dialógicas com o leitor não estão tão explícitas; no segundo, já há o uso do dêitico você, além dos recursos não-verbais que ora trabalham com os conhecimentos presumidos do leitor acerca de outra esfera da atividade (como é o caso, por exemplo, da presença da esfera da arte, na edição de março de 1995, e da presença da esfera da religião, na edição de abril de 1997), ora inserem-se claramente na ideologia do cotidiano (presença de um Band-Aid, na edição de novembro de 1997). No terceiro período, além de o dêitico você ter sido usado ainda mais vezes, há um acréscimo considerável de informações nos títulos. As imagens se referem, em sua totalidade, à ideologia do cotidiano, além de terem se tornado menos rebuscadas que as do segundo período.

Essa mudança no estilo e na forma composicional dos títulos não são somente explicadas pelo diálogo com o leitor que, ao longo dos períodos, foi se acentuando. Há outro fator que influencia nessa mudança. Trata-se da mudança temática. Se, num primeiro momento, o tema se centrava na cura de doenças para manter a saúde, no terceiro período, o tema é a prevenção de doenças que pode ser realizada na própria ideologia do cotidiano. Daí a forte presença de fotos, recursos fraseológicos mais próximos da ideologia do cotidiano no último período. Contudo, 
como se viu, o discurso de cientistas aqui se fez presente, pois é ainda ele aquele o legitimador de como essa prevenção deve ser feita.

Deste modo, em relação à outra categoria analisada nesta dissertação, o discurso citado, pode-se dizer que o discurso dos cientistas foi o que predominou nos três períodos. Mas, devido à mudança temática, as vozes da esfera da ciência foram distribuídas com diferentes objetivos nos períodos: enquanto no primeiro período constataram-se discursos de cientistas que traziam explicações científicas, no último, essas explicações deram lugar a conselhos para a vida prática do leitor.

Além do discurso da ciência, vozes de outras esferas da atividade aparecem citadas nas reportagens, com o objetivo não só de dialogar com o leitor, mas, igualmente aos títulos, de captá-lo para a leitura. Essas vozes tornam a reportagem mais próxima do leitor. Esse é o caso também da divisão da reportagem em várias partes que orientam o leitor nos sub-títulos nela contidos. Os discursos citados estão distribuídos de maneira que, à medida que o conteúdo desses sub-títulos vão sendo desenvolvidos, aparece a voz de um cientista para dar credibilidade à informação contida no contexto narrativo.

Embora seja freqüente a presença dessas outras vozes, como forma de captar o leitor, dialogando com seus conhecimentos, nos discursos citados essas vozes aparecem, na grande maioria dos casos, na forma de discurso indireto analisador da expressão, o que gera um distanciamento do contexto narrativo, mostrando que aquelas vozes são estranhas ao conteúdo temático que a reportagem quer divulgar. Se, por um lado, essas outras vozes funcionam como forma de dialogar com o leitor, elas também ajudam a manter a imagem do discurso científico como aquele que é o único capaz de explicar fenômenos e falar com propriedade sobre o tema da saúde.

A forma de citar o discurso da ciência que predominou nos três períodos foi o discurso direto preparado, pois é a forma que confere maior distanciamento sintático e semântico em relação ao discurso proferido, garantindo ao conteúdo temático veiculado, legitimidade e credibilidade. Os verbos de elocução foram, ao longo dos períodos, perdendo traços que pudessem condicionar a interpretação do leitor, sendo afirmar e dizer as formas predominantes no último período.

Ainda associando o estilo e a forma composicional à mudança temática, um tipo de discurso que apareceu no segundo período e se intensificou no último foi o discurso direto 
substituído que marca lingüisticamente a presença do leitor nas reportagens. Ao fazer perguntas que o leitor poderia se fazer, o jornalista torna-se cúmplice dele não só nas dúvidas, mas nos conhecimentos que ele tem até o momento.

A tipologia de Bakhtin/Voloshinov, desenvolvida para descrever a presença de discurso alheio na literatura, não dá conta de todos os tipos que o corpus levanta no gênero reportagem de divulgação científica no campo jornalístico. Há, por exemplo, o discurso direto seguido de síntese do contexto narrativo e a presença de discurso direto sem aspas que causa, num primeiro momento, uma dupla autoria (a do jornalista e a do cientista), logo assim descaracterizada pela presença de um verbo de elocução. Há, ainda, o discurso indireto analisador do conteúdo com modalizadores que confere uma distância ainda maior ao discurso citado.

Como comentado no capítulo dois, a divulgação científica é uma atividade que se manifesta em gêneros de diferentes esferas. Ao aparecer no gênero reportagem de capa, o tema sofreu as coerções que a esfera do jornalismo comercial lhe impôs, dentre elas, a captação do leitor. À medida que o tema foi se modificando, o estilo e a articulação composicional foram se aproximando mais do cotidiano do leitor, transformando a divulgação de um conhecimento em divulgação de conselhos práticos. 


\section{Referências Bibliográficas}

ADAM, J.M. \& HEIDMAN, U. Des genres à la généricité. L'exemple des contes (Perrault et les Grimm). In: Langages. Paris Larousse, nº153, p.62-72, mars 2004.

AUTHIER-REVUZ, Jacqueline. A encenação da comunicação no discurso de divulgação científica. In: Palavras incertas: as não-coincidências do dizer. Campinas: Unicamp, p.107131,1998 .

Repères dans le champ du discours rapporté. L'information grammaticale, Université de Paris III, n.55, p.38-42, oct. 1992.

BAKHTIN, M. Questões de literatura e estética: a teoria do romance. Trad.Aurora Fornoni Bernadini et al. São Paulo: Unesp/Hucitec, 1988.

BAKHTIN, M. \& MEDVEDEV, P. The formal method in literary scholarship. Translated by Albert J. Wehrle. Baltimore and London: The Johns Hopkins University Press, 1991. (Original russo, 1928).

BAKHTIN, M. \& VOLOSHINOV. Marxismo e filosofia da linguagem. Trad.do francês de Michel Lahud e Yara Frateschi Vieira. 6.ed. São Paulo, Hucitec, 2004. (Original russo, 1929).

BAKHTIN, M. Problemas da poética de Dostoiévski. Trad.de Paulo Bezerra, 2.ed. Rio de Janeiro: Forense Universitária, 2002. (Original russo, 1963, edição revisada).

. Estética da criação verbal. Trad.do russo de Paulo Bezerra. São Paulo: Martins Fontes, 2003. (Original russo, 1979).

BARROS, D.L.P. \& FIORIN, J.L.(Orgs.). Dialogismo, polifonia, intertextualidade. São Paulo: Edusp, 2003.

BOURDIEU, P. Os usos sociais da ciência. Por uma sociologia clínica do campo científico. São Paulo: Editora da UNESP, 2003.

Sobre a televisão. Seguido de: A influência do jornalismo e Os jogos olímpicos. Trad. de Maria Lúcia Machado, Rio de Janeiro: Jorge Zahar Editor, 1997.

BRANDÃO, H.N. (Coord.). Gêneros do discurso na escola: mito, conto, cordel, discurso político, divulgação científica. São Paulo: Cortez, 2000.

BRAIT, B. Interação, gênero e estilo. In: Interação na fala e na escrita. São Paulo: Humanitas, 2002, p. 125-157. p.79-102.

. Estilo. In: BRAIT,B. (Org.) Bakhtin. Conceitos-chave. São Paulo: Contexto, 2005, 
BUENO, W.C. Jornalismo científico no Brasil: uma prática dependente. Tese de doutorado, ECA/USP, São Paulo, 1984.

CEREJA, W. Significação e tema. In: BRAIT,B. (Org). Bakhtin. Conceitos-chave. São Paulo, Contexto, p.201-220, 2005.

CHAUÍ, M. Cultura e democracia: o discurso competente e outras falas. 2.ed., São Paulo: Moderna, 1981.

CLARK, Katerina \& HOLQUIST, Michael. Mikhail Bakhtin. Trad.de J.Guinsburg. São Paulo: Perspectiva, 1998.

FOSSEY, Marcela Franco. A semântica global em duas revistas de divulgação científica: Pesquisa Fapesp e Superinteressante. 2006, Campinas, Dissertação (Mestrado em Lingüística), Instituto de Estudos da Linguagem, Universidade Estadual de Campinas.

GENETTE, Gerard. Seuils. Paris: Seuil, 1987.

GRILLO, Sheila Vieira de Camargo. A produção do real em gêneros do jornal impresso. São Paulo: Associação Editorial Humanitas, 2004.

. Função dos gêneros e metodologia na constituição do corpus em análise do discurso. In: Revista estudos lingüísticos $\left(51^{\circ} \mathrm{GEL}\right)$. Taubaté, vol.32, maio 2003. 1CD.

. O funcionamento de formas do português em gêneros de transmissão de saberes. Projeto de pesquisa (2003-2009).

- A noção de campo nas obras de Bourdieu e do círculo de Bakhtin: suas implicações para a teorização dos gêneros do discurso. Revista ANPOLL, nº19, p. 151-184, jul./dez.2005.

GUIMARÃES, E. O acontecimento para a grande mídia e a divulgação científica. In: GUIMARÃES,E. (Org.). Produção e circulação do conhecimento: estado, mídia, sociedade. Campinas: Pontes, 2001, p. 13-20.

GUIMARÃES, E. A ciência entre as políticas científicas e a mídia. In: GUIMARÃES,E. (Org.). Produção e circulação do conhecimento: estado, mídia, sociedade. Campinas: Pontes, p.73-79, 2001.

ILARI, R.; GERALDI, J.W. Semântica. São Paulo: Ática, 1999.

JACKENDOFF, R. Semantic interpretation in generative grammar. Cambridge: the M.I.T. Press, 1972.

KOCH, I.V. O texto e a construção dos sentidos. São Paulo: Contexto, 1998.

LEITE, M. Promessas e problemas. Pesquisa Fapesp, São Paulo, nº 100, p.62, jun. de 2004. 
MOIRAND, S. Formas discursivas da difusão de saberes na mídia. In: RUA: Revista do núcleo de desenvolvimento da criatividade da UNICAMP - NUDECRI. Campinas, n.6, p.924, mar. 2000.

MOREIRA, I.C. Em ritmo de samba. Pesquisa Fapesp, São Paulo, no 100, p.54-59, jun. de 2004.

ORLANDI, Eni. Divulgação científica e efeito leitor: uma política social urbana. In: GUIMARÃES,E. (Org.). Produção e circulação do conhecimento: estado, mídia, sociedade. Campinas: Pontes, 2001, p. 21-30.

PEYTARD, J. Problématique de l'altération des discours: reformulation et transcodage. In: Langue Française. Paris, Larousse, nº4, p.17-28, 1984.

PESQUISA FAPESP. Deu no Jornal Nacional. Pesquisa Fapesp, São Paulo, nº 100, p.48-53, jun. de 2004.

PEZATTI, Erotilde Goreti. Estruturas coordenadas alternativas. In: NEVES, M.H.M. Gramática do português falado. Vol. VII: Novos Estudos. São Paulo, Humanitas, 1999.

POSSENTI, Sírio. O sujeito fora do arquivo. In: MAGALHÃES, I. (Org). As múltiplas faces da linguagem. Brasília: Editora Universidade de Brasília, 1996.

SILVA, T.D. Jornalismo e a divulgação científica. In: RUA: Revista do núcleo de desenvolvimento da criatividade da UNICAMP - NUDECRI. Campinas, n.8, p.129-146, 2002.

SOUZA, G.T. Introdução à teoria do enunciado concreto do círculo Bakhtin/ Volochinov/ Medvedev. São Paulo: Humanitas, 1999.

- Gêneros discursivos em Marxismo e filosofia da linguagem. In: The Especialist. São Paulo, Educ, vol.24, no especial, p.185-200, 2003.

VICTORELLI, Luís. A ciência na gaveta: um estudo da ciência versus divulgação científica. 2003, Dissertação (Mestrado em Comunicação), ECA/USP, São Paulo.

ZAMBONI, L.M.S. Cientistas, jornalistas e a divulgação científica: subjetividade e heterogeneidade no discurso da divulgação científica. Campinas: Autores Associados, 2001.

Referências do corpus:

BURGIERMAN, Denis Russo. Deveríamos parar de comer carne? Superinteressante. São Paulo, nº175, p.42-50, abr.2002. 
. Maconha. Superinteressante. São Paulo, nº179, p.32-40, ago.2002.

DIEGUEZ, Flávio. O curativo genético. Superinteressante. São Paulo, nº122, p.55-63, nov.1997.

KENSKI, Rafael. A ciência de ser saudável. Superinteressante. São Paulo, no 182, p.42-50, nov. 2002.

LUCÍRIO, Ivonete. Na mira do mosquito assassino. Superinteressante. São Paulo, $\mathrm{n}^{\circ} 118$, p.42-48, jul.1997.

MACCA, Marcelo. Gordos \& Magros. Quem é quem na balança. Superinteressante. São Paulo, no20, p.18-23, mai.1989.

MORAIS, Jomar. Precisamos de tanto remédio? Superinteressante. São Paulo, nº185, p.42-49, fev. 2003.

. Meditação. Superinteressante. São Paulo, nº193, p.56-65, out.2003.

OLIVEIRA, Lúcia Helena. Dor. Este sofrimento pode acabar. Superinteressante. São Paulo, $\mathrm{n}^{\mathrm{o}}$ 6, p.11-19, mar. 1988. out. 1988 .

Medicina Chinesa. Ciência do equilíbrio. Superinteressante. São Paulo, nº 13, p. 44-52, Sangue. Um mergulho neste precioso líquido. Superinteressante. São Paulo, nº26, p.2029, nov.1989. mar. 1995.

. Vitaminas. Ou você toma ou você perde. Superinteressante. São Paulo, no 90, p. 32-43, . No fundo do coração. Superinteressante. São Paulo, nº120, p.82-89, set.1997.

, BARROS, Fernando Valeika. Cosméticos Científicos. Agora a beleza virou assunto dos cientistas. Superinteressante. São Paulo, nº112, p.38-45, jan.1997.

PETTA, Rosângela. Maconha. Um remédio proibido? Superinteressante. São Paulo, n95, p.54-61, ago.1995.

PRADO, Ricardo Chaves. O veneno do bem. Superinteressante. São Paulo, no 115, p.58-65, abr.1997.

VOMERO, Maria Fernanda. Diabete. Superinteressante. São Paulo, nº180, p.42-50, set.2002. 